\title{
СУЧАСНА
}

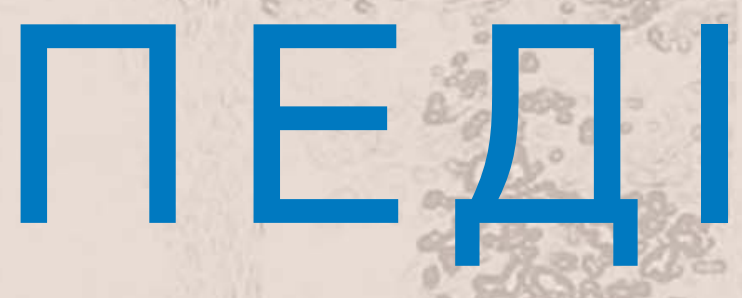

УKPAÏHA

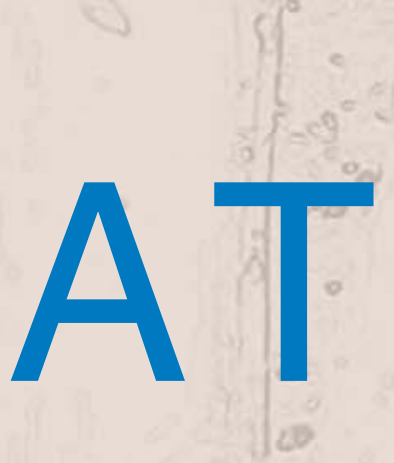

ISSN 2663-7553
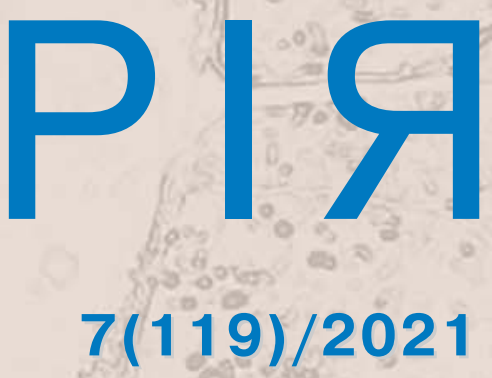

Передплатний індекс 09850

\section{MODERN PEDIATRICS. UKRAINE}

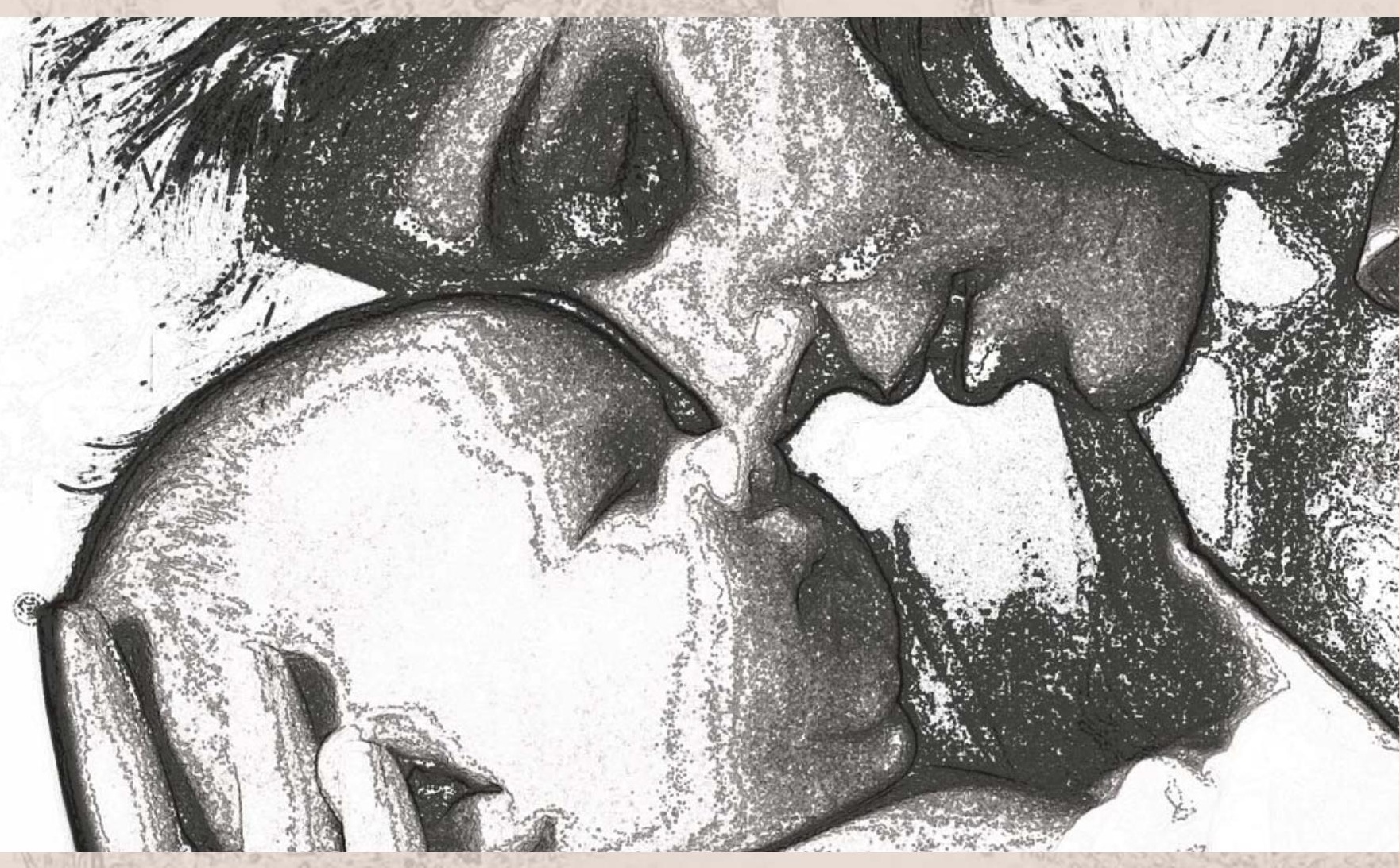

СОВРЕМЕННАЯ ПЕДИАТРИЯ. УКРАИНА 


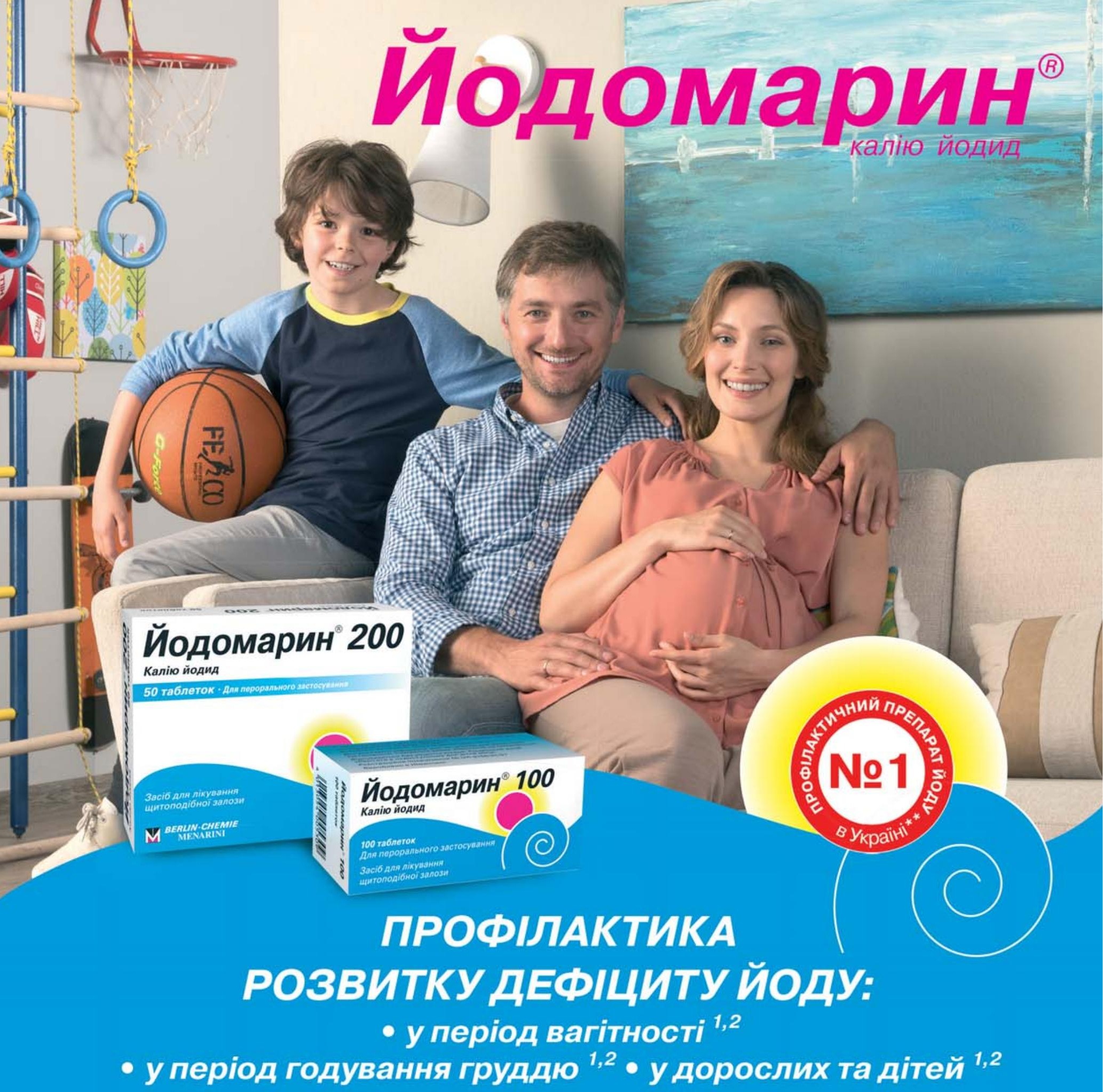

Інформація про безрецептурний лікарський засіб, призначена для медичних та фармацевтичних працівників. Інформація призначена дпя розповсюдження на конференціях та спеціапізованій пресі для медичних та фармацевтичних працівників.

Скорочена інструкція для медичного застосування препарату

ИОДОМАРИН 100 (JODOMARIN 100), ИОДОМАРИН 200 (JODOMARIN 200)

Склад: 1 таблетка 100 містить калію йодиду 131 мкт, що відповідае йодиду 100 мкг а60 1 таблетка 200 містить капію йодиду 262 мкг, що відповідає 200 мкг йодиду; допоміжні речовини: лактози моногідрат, магнію карбонат основний пегкий, жепатин, натрію крохмальгліколят (тип A), кремнію діоксид колоїдий безводний, магнію стезрат. Лікарська форма. Табпетки. Фармакотерапевтична група. Лікарські засоби для лікування захворювань щитоподібноі залози. Тиреоідні лікарські засоби, Лікарські засоби йоду. Код АТХ НОзС А. Показання. Профілактика розвитку дефіциту йоду, у тому числі у період вагітності або годування грудак. Профіпактика рецидиву йододефічитного $306 а$ після хірургічного лікування, а також після завершення комплексного пікування пікарськими засобами гормонів щитоподібноі залози. Лікування дифузного еутиреоідного йододефіцитного зоба у дітей, у тому чиспі у новонароджених інемовлят, та дорослих осіб моподого віку. Протипоказання. Підвищена чутливість до діючої речовини або до будь-якого з допоміжних компонентів пікарського засобу. Виражений гіпертиреоз. У разі латентного гіпертиреозу протипоказано застосовувати пікарський засіб у дозах, що перевищують 150 мкг піоду на добу. У разі автономної аденоми, а також фокальних та дифузних автономних вогнищ щитоподібноі залози протипоказано застосовувати пікарський засібу дозі від 300 до 1000 мкг йоду на добу (за винятком передопераційноі йодотерапії з метою блокади щитоподібної залози за Пламером). Туберкупьоз легенів. Геморагічний діатез. Герпетиформний дерматит Дюринга (синдром Дюринга-Брока). Побічні реакції. При профіпактичному застосуванні йодиду у будь-якому віші, а

ПреДставНИцТВО «БЕРЛПН-ХЕМІ/А. МЕНАРІНІУКРАП̈НА ГМбХ»

Адреса: м. Київ, вул. Березняківська, 29, тел.: (044) 494-3388, факс: (044) 494-3389. також при терапевтичному застосуванні у немовлят та дітей небажаних ефектів, як правило, не спостерігаєься. Проте при наявності великих вогнищ автономіїщитоподібної запози і при призначенні йоду у добових дозах, що перевищують 150 мкг, повністо виключити появу вираженого гіпертиреозу неможливо. $360 \mathrm{ky}$ імунноі системи: реакціі гіперчутливості (такі, наприклад, як риніт, спричинений йодом, бульозна або туберозна йододерма, ексфоліативний дерматит, ангіоневротичниї набряк, гарячка, акне і припухлість слинних залоз). Повний перелік побічних реакцій з боку імунноі, ендокринноі системи та інші знаходяться в інструкиї для медичного застосування препарату Яодомарин 100 , Подомарин`200. Спосіб застосування. Табпетки приімати піспя іди та запивати достатньою кількістю рідини, наприкпад, склянкою води. Немовлятам то дітям до 3-x років пікарський засіб можна давати у подрібненому вигляді. Категорія відпуску. Без рецепта. Повна інформація про лікарський засіб міститься в інструкціях для медичного застосування ИодоМАРИН"

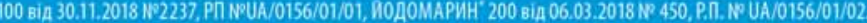
Виробник. БЕРлПН-ХЕМI АГ, Гпінікер Вег 125, 12489 Берлін, Німеччина.

"-3гідно даних роздрібного аудиту Системи дослідження ринку Фармексплорерэ 3 продажів усіх препаратів групи АТХ код 3 НОЗС за період січень -листопад 2020 p.

UA_Jod_04-2021_V1_Press. Maтеріап затверджено 12.02.2021.

1. Інструкиія для медичного застосування препарату ВодОМАРИН* 100 вія 30.11.2018 N/2237, PIIN UA/0156/01/01;

2.1нструкція для медичного застосуванна препарату ИОДОМАРИН" 200 ві 06.03.2018 N 450, PIN UA/0156/01/02.

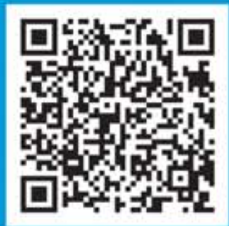

BERLIN-CHEMIE MENARINI 


\section{НОВИЙ РІВЕНЬ ЗАХИСТУ В РОДИНІ}

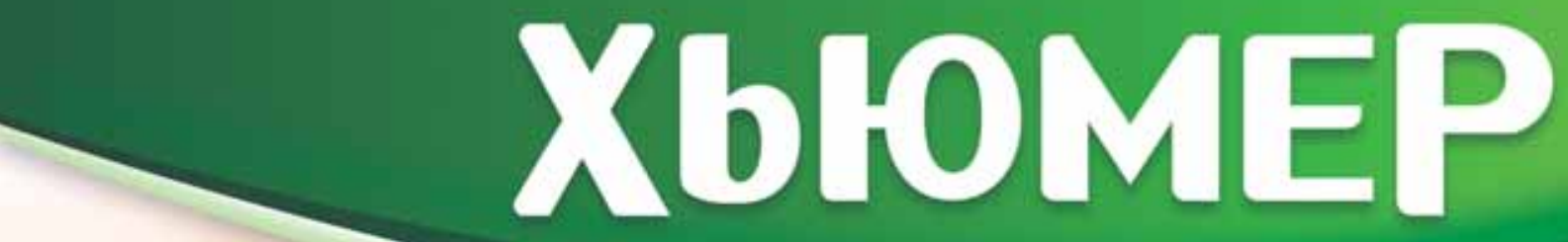

\section{ЗАСТУДА? ГРИП?}

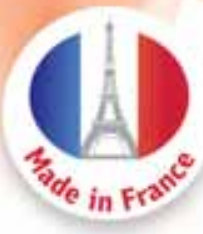

$\mathrm{P}^{\mathrm{OBeAe} / \%}$

कs

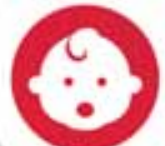

2 pik +
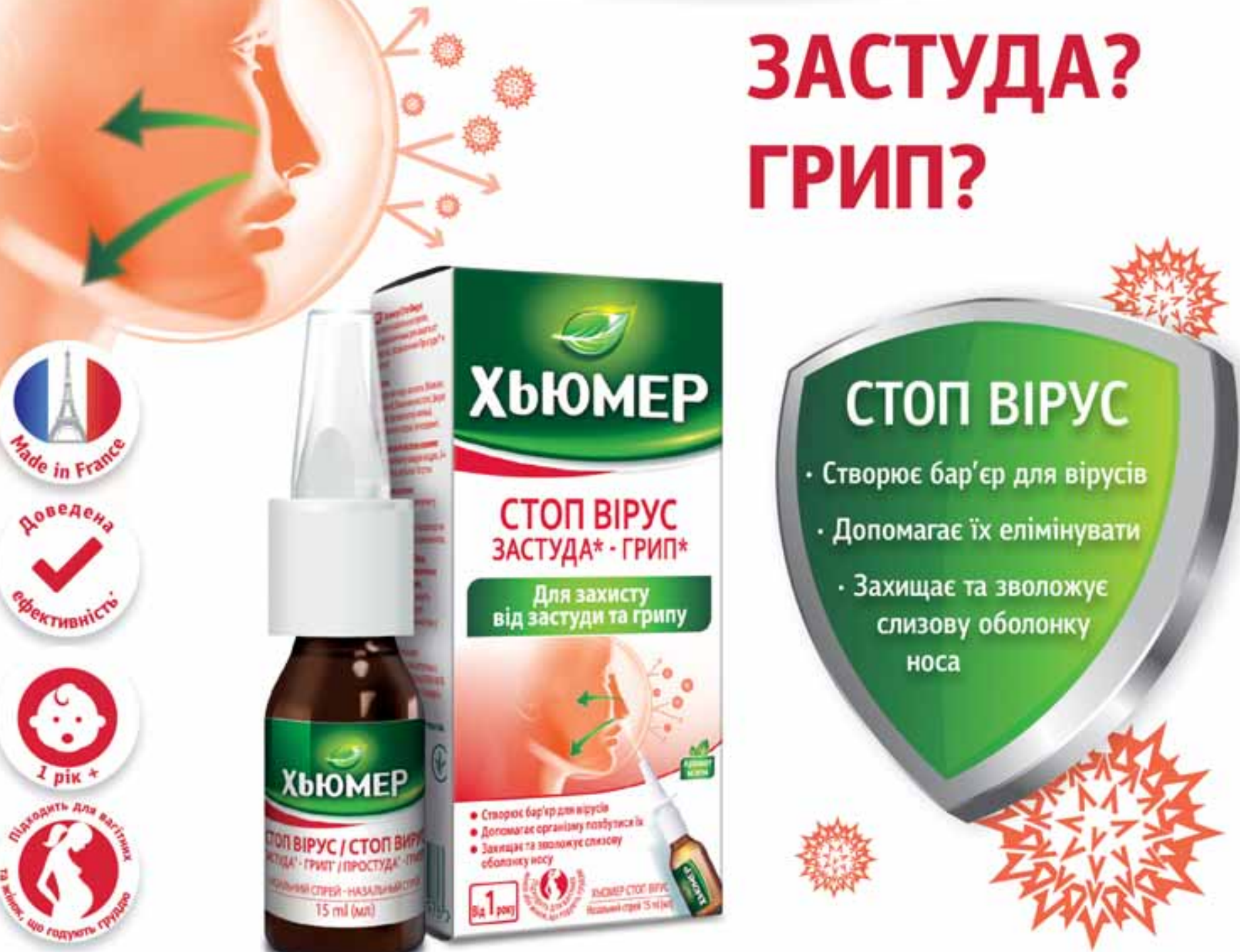

ППРОФІЛАКТИКА

Утворює водну плівку на слизовій оболонці носа, яка немов «щит» захищає від вірусів, що спричиняють застуду та грип

(ВІД ПЕРШИХ СИМПтомІВ ЗАСТУДИ ЧИ ГРИПУ

Уловлює віруси та допомагає організму їх позбутися 


\section{MODERN PEDIATRICS. UKRAINE Scientific and Practical Journal}

Emeritus Editor

Berezhniy V.V., Doctor of Medical Science, Professor of Pediatrics, Shupyk National Healthcare University of Ukraine,

Kyiv, Ukraine

Editor-in-Chief

Chernyshova L.I., Doctor of Medical Science, Professor of Pediatrics, Shupyk National Healthcare University of Ukraine,

Kyiv, Ukraine

Valiulis A., Professor, CEO of Clinic of Asthma, Allergy and Chronic Lung Diseases, CEO of EduCom (postgraduate education), Executive Committee member \& Treasurer of European Academy of Paediatrics (EAP/UEMS-SP), Vilnius,

Lithuania

Chief Scientific Adviser

Antipkin Yu.G., Academician of the National Academy of Medical Science of Ukraine, Director of the SI «Institute of

Pediatrics, Obstetrics and Gynecology named after academician O. Lukyanova of the NAMS of Ukraine», Kyiv

Deputy Editor-in-Chief

Mamenko M.E., Doctor of Medical Science, Professor of Pediatrics, Shupyk National Healthcare University of Ukraine,

Kyiv, Ukraine

Scientific Editor

Marushko R.V., Doctor of Medical Sciences, SI «Institute of Pediatrics, Obstetrics and Gynecology named of academician O.M. Lukyanova of the NAMS of Ukraine», Kyiv

Project Director D.O. Bakhtiyarova

Executive Editor I.O. Sheiko

Layout and design V.S. Scherbatykh

Abaturov A.E. (Dnipro, Ukraine)

Aryayev M.L. (Odesa, Ukraine)

Banadyga N.V. (Ternopil, Ukraine)

Beketova G.V. (Kyiv, Ukraine)

Bogmat L.F. (Kharkiv, Ukraine)

Vaildeliene L. (Kauno, Lithuania)

Veres Gabor (Budapest, Hungary)

Volokha A.P. (Kyiv, Ukraine)

Geppe N.A. (Moscow, Russia)

Gorovenko N.G. (Kyiv, Ukraine)

Hubertus von Voss (Munich, Germany)

Dudnik V.M. (Vinnytsia, Ukraine)

Yemets I.M. (Kyiv, Ukraine)

Zaychenko A.V. (Kyiv, Ukraine)

Zvolinska D. (Wroclaw, Poland)

Ivanov D.D. (Kyiv, Ukraine)

Yspaeva Zh.B. (Almaty, Kazakhstan)

Kvashnina L.V. (Kyiv, Ukraine)

Kozlov R.S. (Smolensk, Russia)

\section{EDITORIAL BOARD}

Kozhyavkin V.I. (Kyiv, Ukraine)
Kosakovskyi A.L. (Kyiv, Ukraine)
Kramarev S.A. (Kyiv, Ukraine)
Curteanu A.M. (Chisinau, Moldova)
Labbe A. (Clermont-Ferrand, France)
Livi P. (Florence, Italy)
Linne T. (Stockholm, Sweden)
Mazur A. (Warsaw, Poland)
Marushko Yu.V. (Kyiv, Ukraine)
Mizernitckyi Yu.L. (Moscow, Russia)
Moiseenko R.O. (Kyiv, Ukraine)
Nakonechna A. (Liverpool, Great Britain)
Nyan'kovskyi S.L. (Lviv, Ukraine)
Ovcharenko L.S. (Zaporizhzhia, Ukraine)
Osidak L.V. (St. Petersburg, Russia)
Okhotnikova E.N. (Kyiv, Ukraine)
Pagava K.I. (Tbilisi, Georgia)
Pilossoff V. (Sofia, Bulgaria)
Pochinok T.V. (Kyiv, Ukraine)

Prodanchuk M.G. (Kyiv, Ukraine)

Puzievicz-Zmonarska A. (Wroclaw, Poland)

Rosenthal M. (London, Great Britain)

Simanis R. (Riga, Latvia)

Slabkiy G.A. (Uzhhorod, Ukraine)

Smiyan A.I. (Sumy, Ukraine)

Umanets T.R. (Kyiv, Ukraine)

Urbonas V. (Vilnius, Lithuania)

Usonis V. (Vilnius, Lithuania)

Hadjipanayis A. (Nicosia, Cyprus)

Husain S. (London, Great Britain)

Chernyshov V.P. (Kyiv, Ukraine)

Shadrin O.G. (Kyiv, Ukraine)

Soder O. (Stockholm, Sweden)

Shyshko G.O. (Minsk, Belarus)

Shun'ko E.E. (Kyiv, Ukraine)

Yankovskyi D.S. (Kyiv, Ukraine)

PUBLISHER GROUP OF COMPANIES MED EXPERT, LLC

Certificate of state registration KВ 23879-13719 ПР from 15.03.2019, the Published since December 2003

Published with the scientific support of the SI «Institute of Pediatrics, Obstetrics and Gynecology named after academician O. Lukyanova of the National Academy of Medical Science of Ukraine» Publishing frequency -8 Times/Year

By the orders of the Ministry of Education and Science of Ukraine No. 612 from May 7, 2019 and No. 1301 from October 15, 2019, the journal «Modern Pediatrics. Ukraine» is included in the List of specialized scientific editions of Ukraine in the field of medical sciences, category B.

Recommended by the Shupyk National Healthcare University of Ukraine, Protocol No.9 from 10.11.2021

Passed for printing 25.11.2021

Mailing address:

GROUP OF COMPANIES MED EXPERT,

«MODERN PEDIATRICS. UKRAINE

p/b 80, Kyiv, Ukraine, 04211

Tel./fax: +38 044 498-08-80

E-mail: pediatr@med-expert.com.ua

http://med-expert.com.ua
Format 60x90/8. Offset paper.

Conventional printed sheet 13.95 .

Total circulation is 8,000 copies.

Ord. No.26.11/01 from 26.11.2021

Printed from the final films

in the «Aurora-print» printing house,

Prichalnaya Str. 5, Kyiv, tel. (044) 550-52-44

Certificate A00No.777897 from 06.07.2009
All articles are reviewed. Total or partial reproduction by any means of the materials published in this edition is allowed only by written permission of the publisher. Advertiser takes responsibility for the content of advertisements.

(C) Shupyk National Healthcare University of Ukraine, 2021

(C) Bakhtiyarova D.O., 2021

«MODERN PEDIATRICS. UKRAINE» Journal was indexed and/or presented in: Scientific Periodicals of Ukraine, Bibliometrics of Ukrainian Science (the Vernadsky National Library), DOAJ, EuroPub, BASE, WordCat, Google Scholar, CrossRef, Ulrich's Periodicals Directory, Sherpa Romeo, Ukrainian abstract journal «Dzherelo» 


\section{СУЧАСНА ПЕАІАТРІЯ. УКРАЇНА \\ Науково-практичний педіатричний жкурнал СОВРЕМЕНHАЯ ПЕАИАТРИЯ. УКРАИНА}

Научно-практический педиатрический журнал

\section{Шеф-редактор}

Бережний В.В., доктор мед. наук, професор, НУОЗ України імені П.Л. Шупика, м. Київ, Україна

Головний редактор

Чернышова Л.І., доктор мед. наук, професор, НУОЗ України імені П.Л. Шупика, м. Київ, Україна

Валіуліс А., професор, Генеральний директор клініки астми, алергії та хронічних захворювань легень, Генеральний директор EduСот (післядипломна освіта), Член Виконавчого комітету та скарбник Європейської академії педіатрії (EAP/UEMS-SP), м. Biльнюс, Литва

Головний науковий консультант

Антипкін Ю.Г., академік НАМН України, директор ДУ «ПАГ імені академіка О.М. Лук'янової НАМН України», м. Київ Заступник головного редактора

Маменко М.Є., доктор мед. наук, професор НУОЗ України імені П.Л. Шупика, м. Київ, Україна

Науковий редактор

Марушко Р.В., доктор мед. наук, ДУ «ІПАГ імені академіка О.М. Лук'янової НАМН України», м. Київ

Директор проекту Д.О. Бахтіярова

Відповідальний редактор I.О. Шейко

Верстка та дизайн В.С. Щербатих

\section{РЕДАКЦІЙНА КОЛЕГІЯ}

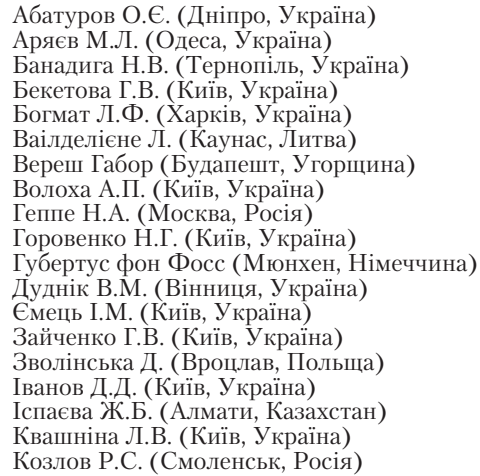

Козявкін В.І. (Київ, Україна)

Косаковський А.Л. (Київ, Україна)

Крамарьов С.О. (Київ, Україна)

Куртяну А.М. (Кишинів, Молдова)

Лаббе Андре (Клермонт-Ферранд, Франція)

Ліві П. (Флоренція, Італія)

Лінне Т. (Стокгольм, Швеція)

Мазур А. (Варшава, Польща)

Марушко Ю.В. (Київ, Україна)

Мізерницький Ю.Л. (Москва, Росія)

Моісеєнко Р.О. (Київ, Україна)

Наконечна А. (Ліверпуль, Велика Британія)

Няньковський С Л (Львів, Україна)

Овчаренко Л.С. (Запоріжжя, Україна)

Осідак Л.В. (С.-Петербург, Росія)

Охотнікова О.М. (Киї, Україна)

Охотнікова О.М. (Киів, У краны
Пагава К.І. (Тбілісі, Грузія)

Пагава К.І. (Тбілісі, Грузія)

Пилоссофф В. (Софія, Болгарія)
Починок Т.В. (Київ, Україна)
Проданчук М.Г. (Київ, Україна)

Пузієвич-Змонарська А. (Вроцлав, Польща)

Розенталь М. (Лондон, Велика Британія)

Сіманіс Р. (Рига, Латвія)

Слабкий Г.О. (Ужгород, Україна)

Сміян А.І. (Суми, Україна)

Уманець Т.Р. (Київ, Україна)

Урбонас В. (Вільнюс, Литва)

Усоніс В. (Вільнюс, Литва)

Хаджипанаіс А. (Нікосія, Кіпр)

Хусаін Ш (Лондон, Велика Британія)

Чернишов В.П. (Київ, Україна)

Шадрін О.Г. (Київ, Україна)

Шедер О. (Стокгольм, Швеція)

Шишко Г.А. (Мінск, Білорусь)

Шунько Є.Є. (Київ, Україна)

Янковський Д.С. (Київ, Україна)

ВИДАВЕЦЬ ТОВ «ГРУПА КОМПАНІЙ МЕД ЕКСПЕРТ»

Свідоцтво про державну реєстрацію СМИ КВ № 23879-13719 ПР від 15.03.2019

Видається за наукової підтримки ДУ «Інститут педіатрії, акушерства і гінекології імені академіка О.М. Лук'янової НАМН України Видається 3 грудня 2003 р.

Періодичність виходу -8 разів на рік

Наказами МОН України від 07.05.2019 № 612 та від 15.10.2019 № 1301 журнал «Сучасна педіатрія. Україна» включено до категорії Б Переліку спеціалізованих наукових видань України в галузі медичних наук. У виданні можуть бути опубліковані основні результати дисертаційних робіт Затверджено вченою радою Національного університету охорони здоров’я України імені П. Л. Шупика 10.11.2021, протокол №09

Підписано до друку 25.11.2021

Адреса для листування:

ТОВ «Група компаній Мед Експерт»,

«Сучасна педіатрія. Україна»

а/с 80, м.Київ-211, Україна, 04211 ,

Тел./факс: +38 044 498-08-80

E-mail: pediatr@med-expert.com.ua

http://med-expert.com.ua/
Формат 60х90/8. Папір офсетний.

Ум. др. арк. 17. Уч.-вид. арк. 13,95

Загальний наклад 8000 прим.

Зам. № 26.11/01 від 26.11.2021

Надруковано з готових фотоформ у типографіі

«Аврора-прінт», м. Київ, вул. Причальна, 5,

тел. (044) 550-52-44

Свідоцтво суб'єкта видавничої справи:

А00 № 777897 від 06.07.2009 р.

(c) Національний університет охорони здоров’я України імені П.Л. Шупика, 2021

(с) Бахтіярова Д.О., 2021

Журнал «Сучасна педіатрія. Україна» включено до науковометричних, реферативних та пошукових баз даних: «Бібліометрика української науки», «Наукова періодика України» (Національної бібліотеки України імені В.І. Вернадського),

DOAJ, EuroPub, BASE, WordCat, Google Scholar, CrossRef, Ulrich's Periodicals Directory, Sherpa Romeо, «Джерело».

Статтям журналу «Сучасна педіатрія. Україна» надається DOI 
НАЩИОНАЛЬНАЯ МЕДИЦИНСКАЯ АКАДЕМИЯ ПОСЛЕДИПЛОМНОГО ОБРАЗОВАНИЯ ИМЕНИ П.Л. ШУПИКА
SHUPYK NATIONAL MEDICAL ACADEMY OF POSTGRADUATE EDUCATION

СУЧАСНА ПЕАIАТРІЯ. УKPAÏHA

Науково-практичний педіатрічний жкурнаА

СОВРЕМЕННАЯ ПЕАИАТРИЯ. УКРАИНА

MODERN PEDIATRICS. UKRAINE

Scientific and Practical Journal

Научно-практический педиатрический журнаА

$7(119) / 2021$

\section{MICT}

\section{БЕЗПЕРЕРВНА МЕДИЧНА ОСВІТА}

Марушко Р.В., Бахтіярова Д.О., Клай С.Р., Загороднюк Д.М. Деякі питання акредитації в рамках безперервного професійного розвитку медичних фахівців в Україні: міжнародний досвід і вимоги

\section{ОРИГІНАЛЬНІ ДОСЛІДЖЕННЯ}

Борисова Т.П., Оболонська О.Ю., Мавропуло Т.К., Бадогіна Л.П., Волков Д.Г. Особливості ренального кровотоку при гострому пошкодженні нирок у недоношених новонароджених дітей з гемодинамічно значущою відкритою артеріальною протокою

Ільченко C.I., Можейко Т.В., Фіалковська А.О., Мишина Н.В. Результати добового моніторингу рівня пепсину в секреті ротової порожнини дітей раннього віку із синдромом регургітації

Воробйова Н.В.

Фактори впливу на виразність клініко-лабораторних проявів синдрому мальабсорбції вуглеводів у дітей раннього віку з ротавірусною інфекцією

Гасанов А.Г., Гусейнова И.Е. Показатели витамина D при коронавирусной инфекции COVID-19 у детей

\section{CONTENT}

\section{CONTINUING MEDICAL EDUCATION}

6 Marushko R.V., Bakhtiiarova D.O., Klai S.R., Zahorodniuk D.M.

Some issues on accreditation within framework of continuing professional development of medical specialists in Ukraine: international experience and requirements

\section{ORIGINAL ARTICLES}

14 Borysova T.P., Obolonska O.Yu., Mavropulo T.K., Badogina L.P., Volkov D.G. Features of renal blood flow in acute kidney injury in premature infants with hemodynamically significant patent ductus arteriosus

19 Ilchenko S.I., Mozheiko T.V., Fialkovska A.O., Mishina N.V.

The results of daily monitoring of salivary pepsin levels in young children with regurgitation syndrome

Vorobiova N.V.

Influencing factors on the severity of clinical and laboratory manifestations of carbohydrate malabsorption syndrome in early-aged children with rotavirus infection

34 Hasanov A.G., Huseinova I.E. Indicators of vitamin D in case of Coronavirus infection COVID-19 in children 
Колоскова О.К., Богуцька Н.К., Тарнавська С.І., Буринюк-Глов'як Х.П. Особливості відповіді на базисну протизапальну терапію школярів з альтернативними запальними фенотипами бронхіальної астми

\section{КЛІНІЧНИЙ ВИПАДОК}

Дутчук О.В., Кочерга З.Р.,

Волошинович В.М.,

Алексеєва Ю.І., Томащук Ю.С.

Клінічний випадок легеневої бластоми в дитини як маскування негоспітальної пневмонії

Погоріла Є.Є.

Клінічний випадок мультисистемного запального синдрому, асоційованого iз SARS-CoV-2

Синоверська О.Б., Алексеєва Ю.І., Фоменко Н.М., Рейтмаєр М.Й., Шкандрій С.Б.

Синдром подовженого інтервалу QT в педіатричній практиці: дані літератури та опис клінічного випадку

\section{ШКОЛА ЛІКАРЯ-ПРАКТИКА}

Крамарьов С.О., Євтушенко В.В. Роль азитроміцину в антибактеріальній терапії гострих респіраторних інфекцій у дітей

Марушко Ю.В., Єсипова С.І., Гищак Т.В. Вплив забезпечення вітаміном D на перебіг гострих респіраторних інфекцій у дітей

МІЖНАРОДНІ КЛІНІЧНІ ПРОТОКОЛИ,
РЕКОМЕНДАЦІІІ

Центри з контролю та профілактики захворювань (CDC). Вакцини проти COVID-19 для дітей і підлітків

Національний інститут здоров'я (NIF). COVID-19 Рекомендації 3 лікування (закінчення)
40 Koloskova O.K., Bogutska N.K., Tarnavska S.I., Buryniuk-Hloviak H.P. Peculiarities of response to basic anti-inflammatory therapy of schoolchildren with alternative inflammatory phenotypes of bronchial asthma

\section{CLINICAL CASE}

46 Dutchuk O.V., Kocherha Z.R., Voloshynovych V.M.,

Alekseeva Yu.I., Tomashchuk Yu.S.

Clinical case of pulmonary blastoma

in a child as a disguise

of community-acquired pneumonia

51 Pohorila Ye.Ye.

Clinical case

of SARS-CoV-2-associated

multisystem inflammatory syndrome

55 Synoverska O.B., Alekseeva Yu.I., Fomenko N.M., Reitmaier M.Y.,

Shkandrii S.B.

Prolonged QT interval syndrome in pediatric practice: literature data and clinical case description

\section{PRACTICAL DOCTOR SCHOOL}

62 Kramarov S.O., Yevtushenko V.V. The role of azithromycin in the antibacterial therapy of acute respiratory infections in children

72 Marushko Yu.V., Esipova S.I., Gishchak T.V. Influence of vitamin $D$ provision on the course of acute respiratory infections in children

\section{THE INTERNATIONAL CLINICAL PROTOCOLS, RECOMMENDATIONS}

81 Centers for Disease Control and Prevention (CDC). COVID-19 Vaccines for Children and Teens

84 National Institutes of Health.

COVID-19 Treatment

Guidelines 


\title{
Р.В. Марушко', Д.О. Бахтіярова², С.Р. Клай², Д.М. Загороднюк ${ }^{2}$ \\ Деякі питання акредитації в рамках безперервного професійного розвитку медичних фахівців в Україні: міжнародний досвід і вимоги
}

\author{
'ДУ «Інститут педіатрії, акушерства і гінекології імені академіка О.М. Лук'янової НАМН України», м. Київ
} ${ }^{2} \mathrm{TOB}$ «Група компаній Мед Експерт», м. Київ, Україна

Modern Pediatrics. Ukraine. (2021). 7(119): 6-13. doi 10.15574/SP.2021.119.6

For citation: Marushko RV, Bakhtiiarova DO, Klai SR, Zahorodniuk DM. (2021). Some issues on accreditation within framework of continuing professional development of medical specialists in Ukraine: international experience and requirements. Modern Pediatrics. Ukraine. 7(119): 6-13. doi 10.15574/SP.2021.119.6.

Безперервна медична освіта (БМО), або безперервний професійний розвиток (БПР), що наразі впроваджується в Україні, $є$ навчанням упродовж усієї професійної кар'єри, яке дає змогу медичним працівникам ефективно виконувати професійні обов'язки з найкращими результатами. Це досягається завдяки злагодженій співпраці акредитаційних органів, провайдерів або організаторів БПР і медичних фрахівців, а також шляхом впровадження ефективної моделі акредитації, яка і буде забезпечувати надання провайдерами належної освіти dмедичним працівникам.

Мета - описати основні принципи освітньої діяльності в рамках БПР, що базується на моделі акредитації провайдерів БПР, яка наразі є загальновизнаною та найефективнішою у світі.

Рекомендації, надані в статті, можуть бути використані учасниками БМО/БПР або зацікавленими сторонами, які націлені на активну участь у впровадженні нової системи акредитації.

Автори заявляють про відсутність конфлікту інтересів.

Ключові слова: безперервний просресійний розвиток, безперервна медична освіта, акредитація, провайдер, медичні фрахівці, освітня діяльність.

\section{Some issues on accreditation within framework of continuing professional development of medical specialists in Ukraine: international experience and requirements R.V. Marushko', D.O. Bakhtiiarova'2, S.R. Klai', D.M. Zahorodniuk ${ }^{2}$ \\ 'SI «Institute of Pediatrics, Obstetrics and Gynecology named after academician 0.M. Lukyanova of the NAMS of Ukraine», Kyiv ${ }^{2}$ Group of Companies Med Expert, LLC, Kyiv, Ukraine}

Continuing medical education (CME) or continuing professional development (CPD), which is currently being implemented in Ukraine, is an education throughout a professional career, which allows medical healthcare providers effectively perform their professional duties with the best results. This is achieved thanks to the coherent cooperation of accreditation bodies, providers or organizers of CPD and medical specialists, as well as by introducing an effective model of accreditation, which ensures that providers are provided medical workers with the proper education.

Purpose - to describe the basic principles of educational activity within the framework of CPD, based on the provider accreditation model which is currently generally recognized and most effective in the world.

Recommendations provided in the article can be used by the CME/CPD participants or stakeholders who are aimed at active participation in the implementation of a new accreditation system.

Key words: continuing professional development, continuing medical education, accreditation, provider, medical specialists, education activities.

\section{Некоторые вопросы аккредитации в рамках непрерывного профессионального развития медицинских специалистов в Украине: международный опыт и требования}

Р.В. Марушко', Д.О. Бахтиярова', С.Р. Клай', Д.М. Загороднюк ${ }^{2}$

'ГУ «Институт педиатрии, акушерства и гинекологии имени академика Е.М. Лукьяновой НАМН Украины», г. Киев

²000 «Группа компаний Мед Эксперт», г. Киев, Украина

Непрерывное медицинское образование (ВМО) или непрерывное просессиональное развитие НПР, которое сегодня внедряется в Украине, является учебой на протяжении всей профессиональной карьеры, позволяющей медицинским работникам эфффективно исполнять свои просрессиональные обязанности с наилучшими результатами. Это достигается благодаря согласованному сотрудничеству аккредитационных органов, провайдеров или организаторов НПР и медицинских специалистов, а также путем внедрения эффективной модели аккредитации, которая и будет обеспечивать предоставление провайдерами надлежащего образования медицинским работникам.

Цель - описать основные принципы образовательной деятельности в рамках НПР, что базируется на модели аккредитации провайдеров НПР, являющаяся общепризнанной и наиболее эфффективной в мире.

Рекомендации, предоставленные в статье, могут быть использованы участниками НМО/НПР или заинтересованными сторонами, которые нацелены на активное участие во внедрении новой системы аккредитации.

Авторы заявляют об отсутствии конфрликта интересов.

Ключевые слова: непрерывное профессиональное развитие, непрерывное медицинское образование, аккредитация, провайдер, медицинские специалисты, образовательная деятельность. 


\section{Загальна інформація}

Для забезпечення найкращого надання медичних послуг і допомоги пацієнтам медичні працівники мають постійно навчатися. Саме через безперервну освіту протягом практичної діяльності медичні працівники підтримують і постійно удосконалюють власний професіоналізм. Безперервна медична освіта (БМО), або безперервний професійний розвиток (БПР), який наразі впроваджується в Україні, є навчанням упродовж усієї професійної кар'єри, що дає змогу медичним працівникам ефективно виконувати професійні обов'язки з найкращими результатами. Це досягається завдяки злагодженій співпраці акредитаційних органів, провайдерів або організаторів БПР і медичних фахівців, а також шляхом впровадження ефективної моделі акредитації, яка і забезпечуватиме надання провайдерами належної освіти медичним працівникам [5].

Системи акредитації в рамках БПР, що існують у світі, сприяють професійному зростанню та підвищенню ефективності роботи медичних працівників. Вони докладають цілеспрямованих, узгоджених зусиль для визначення єдиних принципів, що можуть бути основою для створення й впровадження максимальної еквівалентності між різними системами акредитації БПР [5,6].

Акредитоване співтовариство безперервної освіти відіграє важливу роль у навігації складних взаємовідносин між медичною спільнотою та комерційним інтересом. Хоча інтереси системи охорони здоров'я та бізнесу іноді розходяться, вони є законними, і співпраця між медичними працівниками та комерційним інтересом, як свідчить практика, сприяє суттєвому поліпшенню медичної допомоги пацієнтам. Слід зазначити, що «незалежність» є основою акредитованої безперервної освіти. Вона має надавати медичним працівникам захищений, вільний від впливу комерційного інтересу простір, для вивчення, викладання та участі в освітній діяльності $[1,7]$.

В Україні впровадження нової системи акредитації має сприяти розвитку БПР, підтримувати та удосконалювати професіоналізм медичних працівників упродовж іх практичної діяльності з метою надання висококваліфікованої, медичної допомоги, поліпшенню рівня здоров'я та благополуччя населення України.

Ця стаття була підготовлена на підставі аналізу досвіду відомих міжнародних організацій, які успішно працюють у рамках БМО/БПР та використовують моделі акредитації, що визнаються в більшості розвинутих країн. У цих організаціях доволі ефективно працюють апробовані впродовж багатьох років акредитаційні вимоги (критерії, стандарти тощо), виконання яких дає змогу провайдерам або організаторам БПР забезпечувати безперервну освіту медичних працівників на високому рівні.

У статті визначено основні принципи БПР медичних працівників, що базуються на моделі акредитації провайдерів БПР, яка наразі $\epsilon$ загальновизнаною та найефективнішою у світі. Матеріали статті розроблено на підставі чинних документів Міністерства охорони здоров'я України (МОЗ України) [2,3], міжнародних документів [1,4], а також досвіду міжнародних організацій, зокрема Акредитаційної ради безперервної медичної освіти, США (Accreditation council for Continuing Medical Education, USA), Королівського коледжу лікарів і хірургів, Канада (Royal College of physicians and surgeons (Canada) та національних провайдерів БПР, які досягли значних успіхів і забезпечують акредитовану безперервну освіту на рівні міжнародних стандартів.

У статті застосовано таку термінологію:

Організація, яка має право на акредитацію (прийнятна організація) - організація, місією та основною діяльністю якої є надання клінічних послуг безпосередньо пацієнтам i/або організація освіти медичних працівників.

Організація, яка не має права на акредитацію (неприйнятна організація) - організація, основним видом діяльності якої є виробництво, маркетинг, продаж, перепродаж або поширення медичних виробів для пацієнтів.

Комерційна підтримка - фінансова підтримка або будь-яка інша підтримка компаній, які не мають права на акредитацію.

Акредитована безперервна освіта - освіта, яка надає медичним працівникам актуальні, високоякісні, науково обгрунтовані знання, сприяє розвитку та вдосконаленню практичних навичок, забезпечує незалежність освітньої діяльності від впливу комерційного інтересу і намірів включення комерційної упередженості. Наразі термін «акредитована безперервна освіта» вживають замість терміну «безперервна медична освіта/безперервний професійний розвиток» стосовно всіх медичних професій. Цей термін введено для чіткого розмежування акредитованих і неакредитованих провайдерів, акредитованої і неакредитованої освіти.

Акредитаційна рада з питань безперервного професійного розвитку (АРБПР) - акредитаційний орган, який працює та забезпечує 
виконання акредитаційних вимог у рамках БПР.

Платформа БПР - електронна автоматизована інформаційно-телекомунікаційна система, що забезпечує доступ до електронних інформаційних ресурсів на всіх етапах акредитаційного процесу, упорядкування збору даних про освітню діяльність акредитованих провайдерів та учасників БПР, зв'язок з атестаційними структурами, а також електронне надання сертифікатів за участь в освітніх заходах БПР.

Безперервна медична освіта (БМО) освітня діяльність, метою якої є отримання та вдосконалення знань і практичних навичок у професійній діяльності медичних працівників для ефективнішого надання медичної допомоги населенню. Зміст БМО - сукупність знань і навичок, загальновизнаних та прийнятих професією в рамках фундаментальних медичних наук, дисциплін клінічної медицини.

Безперервний професійний розвиток (БПР) - навчання упродовж усієї професійної кар'єри, яке дає змогу медичним працівникам ефективно виконувати професійні обов'язки з найкращими результатами.

\section{Впровадження моделі акредитації провай- дерів в Україні}

На шляху подальшого розвитку та удосконалення безперервної освіти в Україні важливу роль відіграє використання досвіду країн зі стабільною, високоякісною безперервною системою професійної підготовки та освіти медичних працівників, що надає змогу розвивати та удосконалювати БПР медичних фахівців у нашій країні.

32018 р. в Україні послідовно здійснюється впровадження та удосконалення БПР [2], на порядку денному стоїть імплементація нової моделі акредитації освітньої діяльності.

Найбільш досконалою, результативною i всесвітньо визнаною на сьогодні є модель «акредитації провайдерів освітньої діяльності», на відміну від моделі «акредитації освітніх заходів». Ця модель має суттєві переваги над іншими:

- під час акредитації провайдерів БПР оцінюють їхню діяльність і відповідність акредитаційним вимогам (критеріям і стандартам акредитації);

- вона дає змогу краще організувати освітній процес у цілому та здійснювати належний контроль за освітньою діяльністю;

- акредитовані провайдери набувають повноважень на самостійне проведення освітніх заходів та несуть повну відповідальність за відповідність вимогам і стандартам БПР;

- акредитація провайдерів гарантує, що безперервна освіта розроблена таким чином, щоб бути актуальною, науково обгрунтованою, заснованою на практиці, високоякісною, ефективною і незалежною від комерційного впливу;

- робота акредитованих провайдерів безперервної освіти суттєво сприяє вдосконаленню практики та дає змогу медичним працівникам оптимізувати догляд за пацієнтами, забезпечити їхнє здоров'я та благополуччя;

- тільки акредитовані провайдери мають право надавати бали (кредити) учасникам освітніх заходів відповідно до наказу МО3 України «Деякі питання безперервного професійного розвитку лікарів» від 22.02.2019 № 446;

- впровадження акредитації провайдерів сприятиме досягненню суттєвої еквівалентності міжнародним стандартам акредитованої освіти та приєднанню України до світового співтовариства БПР.

Отже, головною місією на сучасному етапі є подальше удосконалення БПР в Україні, а гарантом успішного виконання цього завдання - впровадження та використання моделі акредитації провайдерів БПР.

\section{Акредитаційний орган}

Важливу роль в організації та забезпеченні БПР відіграє акредитаційний орган, який є головним регулятором БПР медичних працівників.

3 метою ефективного впровадження та забезпечення БПР МОЗ України планує створити акредитаційну раду безперервного професійного розвитку, завданнями якої мають бути:

- організація та координація методичного забезпечення БПР медичних працівників, моніторинг його ефективності;

- здійснення контролю за освітньою діяльністю та дотриманням провайдерами БПР вимог акредитації;

- розроблення критеріїв та стандартів акредитації для організацій, які мають намір бути провайдерами, а також контроль за їх ретельним виконанням під час освітньої діяльності;

- проведення оцінки відповідності вимогам акредитації провайдерів БПР та визначення термінів акредитації;

- розроблення документації (інструктивних матеріалів, настанов, нормативних документів, звітів, тощо), необхідної в процесі акре- 
дитації провайдерів, надання їм статусу «Акредитований провайдер» та в подальшій діяльності;

- організація та проведення навчання провайдерів БПР з метою їх ознайомлення 3 принципами БПР, процесом акредитації, критеріями та стандартами відповідності акредитаційним вимогам, обов'язками та правами акредитованих провайдерів під час планування, організації, проведення та оцінювання результатів освітньої діяльності;

- створення консультативного комітету, до складу якого мають входити представники всіх категорій провайдерів. Його завданням є співпраця з акредитаційною радою, участь у прийнятті рішення щодо присвоєння провайдерам статусу «Акредитований провайдер», підготовка звітів, розроблення й затвердження настанов та інших нормативних документів.

- створення групи незалежних рецензентів / експертів для оцінки та рецензування контенту;

- створення та впровадження в роботу «платформи БПР», яка забезпечить доступ до електронних інформаційних ресурсів на всіх етапах акредитаційного процесу провайдерів, упорядкування збору даних про освітню діяльність акредитованих провайдерів (план акредитованих заходів) та учасників БПР (освітнє портфоліо), зв'язок з атестаційними структурами, електронне надання сертифікатів за участь в освітніх заходах БПР;

- забезпечення технічної підтримки «Платформи БПР», оброблення та аналіз внесених відомостей, збереження та захист даних, що містяться в реєстрах, забезпечення доступу працівників сфери охорони здоров'я, провайдерів, представників державних органів до цієї системи.

\section{Вимоги до провайдерів в системі БПР}

Для успішного виконання цілей і завдань акредитованої БМО діяльність акредитованих провайдерів має відповідати затвердженим вимогам акредитації.

Під час розроблення та реалізації освітніх заходів враховуються основні складові - планування, підготовка, презентація та оцінка ефективності.

Для забезпечення виконання акредитаційних вимог провайдери мають:

- ознайомитися з освітніми матеріалами, що розробляються та надаються акредитаційним органом для отримання повного уявлення про вимоги та особливості процесу акредитації;
- брати участь у навчанні (тренінгах) з метою засвоєння знань і практичних навичок під час планування, організації, проведення та оцінювання результатів освітньої діяльності, чіткого уявлення про свої обов'язки;

- оцінити відповідність їхньої організації акредитаційним вимогам;

- мати певні людські, технічні, фінансові та фізичні ресурси для організації освітньої діяльності в рамках БПР;

- відповідати за виконання вимог акредитаційного органу;

- $\quad$ здійснювати контроль за якістю БПР та дотриманням відповідності критеріям і стандартам акредитації освітньої діяльності;

- проводити освітню діяльність відкрито, прозоро, на основі академічної доброчесності та дотримання засад доказової медицини;

- застосовувати сучасні інформаційні технології на всіх етапах планування, організації, проведення та оцінки результатів освітньої діяльності;

- зберігати всі матеріали проведених освітніх заходів протягом 6 років;

- забезпечувати незалежність освітньої діяльності від впливу комерційного інтересу та 3 дотриманням стандартів доброчесності й незалежності.

Вимоги до освітньої діяльності в рамках акредитованої безперервної освіти

Для успішного виконання цілей і завдань БМО діяльність провайдерів має відповідати акредитаційним вимогам, що дає змогу ефективно розробляти й реалізовувати освітні заходи. Хоча різні системи акредитації мають певні особливості в різних країнах, вимоги та критерії БПР принципово не різняться і грунтуються на основних компонентах БПР.

Під час планування, підготовки, проведення та оцінювання провайдер має виконати такі вимоги (критеріi):

- визначення основної мети (місіі) освітньої програми (освітньої діяльності) із висвітленням очікуваних результатів, сформульованих з точки зору змін компетентності лікарів, ефективності/продуктивності їхньої діяльності або змін у наданні медичної допомоги пацієнтам, що відображатиме результати виконання програми;

- визначення у своїй діяльності освітніх потреб (знання, компетентність, практичні навички, продуктивність/ефективність виконання професійних обов'язків) для усунення 
недоліків у професійній практиці медичних працівників;

- визначення цілей освітніх заходів на підставі визначених освітніх потреб, що є основою ефективного й результативного планування освітньої діяльності/освітніх програм;

- забезпечення обгрунтування та підготовки контенту освітніх заходів або програм, для медичних працівників, враховуючи що зміст освітньої діяльності - це сукупність знань і практичних навичок, загальновизнаних і прийнятих у професії в рамках базових медичних наук, клінічної медицини та практичного надання медичної допомоги населенню;

- обрання формату для освітніх заходів, що відповідає умовам, цілям і бажаним результатам заходу;

- визначення науково-викладацького складу (це передбачає відбір потенційних кандидатів з урахуванням конфлікту інтересів);

- створення умов для підготовки змісту презентацій, відповідальність за яку несе спікер (це стосується всіх форм інтерактивної взаємодії з аудиторією). Загальна відповідальність за організацію освітнього заходу в рамках БПР покладена на провайдера;

- оцінювання результатів освітньої діяльності для визначення іï ефективності, проведення аналізу змін в знаннях, компетентності, результативності виконання професійних обов'язків, практичних навичок та надання медичної допомоги пацієнтам, досягнутих в результаті проведеного навчання. Оцінка результатів освітньої діяльності є основним стандартом акредитації БПР для визначення ефективності освітньої діяльності.

\section{Акредитація провайдерів БПР}

Акредитаційний процес, що передбачає визначення відповідності акредитаційним вимогам (критеріям, стандартам) організацій, які мають намір бути акредитованими провайдерами, має позитивні результати в забезпеченні безперервною освітою медичних працівників та наданні медичної допомоги пацієнтам.

Для отримання статусу «Акредитований провайдер» організація має відповідати таким критеріям:

- розробляти та представляти освітні заходи (зміст) для медичних працівників на регулярній основі, базуючись на досягненнях сучасної науки, клінічному досвіді та науковообгрунтованих доказах, які надають достатньо збалансоване уявлення про діагностичні й терапевтичні можливості;
- не сприяти розповсюдженню рекомендацій, лікування або підходів надання медичної допомоги, які мають ризик або небезпеку, що перевищують користь або є неефективними в лікуванні пацієнтів;

- надавати освітні заходи, зміст яких є актуальним, обгрунтованим, пропагує рекомендації, лікування або досягнення практичної медицини, які підходять під визначення «акредитована безперервна освіта» (безперервна медична освіта, безперервний професійний розвиток);

- запобігати комерційному упередженню або впливу комерційного інтересу;

- бути організацією, місією та основною діяльністю якої є надання клінічних послуг безпосередньо пацієнтам, i/або організацією освіти медичних працівників.

Процес акредитації передбачає:

1. Акредитація провайдерів БПР починається 3 реєстрації на платформі БПР, для чого подається заявка в електронній формі.

Провайдер повинен розробити документи, в яких мають бути прописані обов'язкові настанови, зокрема:

- місія (цілі та завдання організаціі);

- організаційна структура;

- положення про забезпечення освітньої діяльності на принципах академічної доброчесності, найкращої існуючої практики і доказової медицини;

- опис механізму визначення фінансових взаємовідносин із комерційним інтересом, виявлення та розв'язання конфлікту інтересів у тих, хто контролює зміст освітніх заходів або програм;

- опис забезпечення належного врядування комерційної підтримки, взаємодії зі спонсорами та незалежності від комерційного інтересу;

- опис оцінки результатів освітньої діяльності організації (набутих знань, компетентностей, продуктивності, практичних навичок працівників сфери охорони здоров'я та результатів надання медичної допомоги пацієнтам).

- механізм правовідносин з особами, якими провадиться діяльність із виробництва, оптової та роздрібної торгівлі, імпорту лікарських засобів і медичних виробів та запобігання конфлікту інтересів під час проведення заходів БПР.

2. Акредитаційна рада у співпраці з консультативним комітетом після оцінки діяльності організації та підтвердження, що вона відповідає вимогам акредитації, а її практична діяльність проводиться відповідно до стандартів 
БПР, приймає рішення про надання статусу «Акредитований провайдер».

3. Усі взаємовідносини з акредитаційною радою відбуваються через платформу БПР (внесення інформації, непорозуміння тощо).

4. Провайдер може вносити відомості до електронної системи про акредитацію міжнародними організаціями у сфері БПР, які є акредитаційними органами та мають право акредитувати провайдерів.

5. Якщо національний провайдер БПР має міжнародну акредитацію Акредитаційної ради безперервної медичної освіти (США), Королівського коледжу лікарів та хірургів (Канада), підтверджену відповідними офіційними документами, то такий провайдер звільняєтеся від проходження акредитації, а статус акредитованого провайдера присвоюється йому автоматично із затвердженням акредитаційною радою БПР.

\section{Стандарти доброчесності та незалежності в акредитованій безперервній освіті}

Організації, акредитовані для забезпечення безперервної освіти, відомі як акредитовані провайдери, несуть відповідальність за забезпечення доступу медичних працівників до навчальної діяльності та розвитку практичних навичок, що заслуговують на довіру та базуються на найкращих практиках і високоякісних доказах.

Ця діяльність має відповідати потребам пацієнтів, а не організаціям, які мають комерційний інтерес.

1. Стандарти, за якими мають працювати акредитовані провайдери, призначені:

- гарантувати, що акредитована безперервна освіта відповідає потребам пацієнтів і громадськості;

- надавати медичним працівникам лише актуальні, зважені, науково-обгрунтовані рекомендації;

- запевнити медичних працівників, що вони можуть довіряти акредитованій безперервній освіті, яка допомагає їм забезпечити безпечну, ефективну, економічно вигідну, співчутливу допомогу, що базується на передовому досвіді та науково обгрунтованих доказах;

- створити чітке, нездоланне розділення між акредитованою системою безперервної освіти та комерційним інтересом, який не матиме права впливати або контролювати будьякий аспект планування, надання або оцінки акредитованої безперервної освіти.

2. Акредитовані провайдери несуть відповідальність за те, щоб їхня освіта була обгрунто- ваною та збалансованою, а будь-який клінічний зміст відповідав безпечному й ефективному наданню медичної допомоги пацієнтам:

- усі рекомендації в акредитованій системі безперервного навчання мають базуватися на досягненнях сучасної науки, клінічному досвіді та науково обгрунтованих доказах, які надають достатньо збалансоване уявлення про діагностичні й терапевтичні можливості;

- усі наукові дослідження мають відповідати загальновизнаним стандартам експериментального дизайну, збору даних, аналізу та інтерпретації;

- акредитовані провайдери не можуть використовувати не наукові підходи до діагностики або терапії, їхня освітня діяльність не має сприяти рекомендаціям, лікуванню або підходам надання медичної допомоги, які мають ризик або небезпеку, що перевищують користь або є неефективними в лікуванні пацієнтів.

3. Акредитована безперервна освіта має запобігати комерційному упередженню або маркетингу:

- акредитовані провайдери повинні забезпечити, щоб усі рішення, пов'язані з плануванням, вибором викладачів, проведенням та оцінкою акредитованої освіти, приймалися без будь-якого впливу або участі комерційного інтересу;

- акредитована освіта має бути вільною від маркетингу або продажу комерційної продукції чи надання послуг.

4. Акредитовані провайдери відповідають за виявлення відповідних фінансових відносин між особами (які беруть участь у плануванні й підготовці навчального змісту) та компаніями (що не відповідають вимогам акредитації), контролюють ці відносини, попереджаючи внесення комерційних упереджень в освіту:

- акредитовані провайдери забезпечують надання інформації від усіх учасників освітньої діяльності, хто контролює та бере участь у підготовці навчального контенту, про всі їхні фінансові відносини з компаніями, які не мають права на акредитацію;

- власники або працівники компаній, які не мають права на акредитацію, повинні бути відсторонені від контролю за змістом освітніх заходів або участі в них як планувальники або викладачі акредитованої освіти;

- акредитовані провайдери мають вжити заходів для запобігання комерційного упередження змісту за участю тих осіб, які мають від- 
повідні фінансові відносини, ще до того, як ці особи починають виконувати власні обов'язки;

- розкриття інформації медичним працівникам про фінансові відносини передбачає надання даних про імена осіб, які мають відповідні фінансові відносини, про назви компаній, які не відповідають вимогам акредитації, 3 якими ці особи мають відносини, про характер відносин, а також заяву про прийняття відповідних заходів щодо виявлених фінансових відносин.

5. Акредитовані провайдери, які вирішили прийняти комерційну підтримку, відповідають за забезпечення незалежності освіти від комерційного інтересу і за попередження комерційної упередженості чи комерційного впливу на акредитовану освіту:

- строки, умови та цілі комерційної підтримки мають бути задокументовані в угоді між компанією, яка не має права бути акредитованою, та акредитованим провайдером.

6. Акредитовані провайдери несуть відповідальність за те, щоб акредитована освіта була відокремлена від маркетингу компаній, які не відповідають вимогам акредитації, включаючи рекламу, продаж, виставки та просування продукції, а також від неакредитованої освіти, яка пропонується разом з акредитованою системою безперервної освіти:

- домовленості, що дають змогу компаніям, які не відповідають критеріям акредитаціï, організовувати маркетинг або виставки, у співпраці з акредитованою освітою, не мають впливати на будь-які рішення, пов'язані з плануванням, проведенням та оцінкою освітніх заходів, втручатися в проведення освітніх заходів, бути умовою надання фінансової або натуральної підтримки від компаній, що не мають права на акредитацію;

- акредитовані провайдери повинні забезпечити, щоб медичні фахівці легко розрізняли акредитоване навчання та інші види діяльності.

Атестація медичних працівників та акредитована безперервна освіта

Результати проходження освітніх заходів обов'язково враховують під час атестації медичних працівників для присвоєння або під- твердження кваліфікаційної категорії, що спрямовано на удосконалення діяльності закладів охорони здоров'я усіх форм власності для подальшого поліпшення надання медичної допомоги населенню.

1. Порядок проведення атестації працівників сфери охорони здоров'я, кількість балів за проходження заходів БПР, у тому числі організованих провайдерами інших держав та проведених за межами України, визначається наказом МОЗ України від 22.02.2019 № 446 «Деякі питання безперервного професійного розвитку лікарів».

2. У разі проходження заходів, що проводяться в країнах із високим рівнем доходу (за рейтингом Світового Банку) або акредитовані Акредитаційною радою безперервної медичної освіти США або Королівським коледжем лікарів та хірургів Канади, під час підрахунку кількість балів множиться на 2.

3. Бали БПР нараховують за здобуття формальної, неформальної та інформальної освіти у сфері охорони здоров'я. Мінімальна кількість балів, яка має бути отримана за річний період, становить 50 балів (максимальна кількість балів - не обмежена).

\section{Висновки}

Для забезпечення найкращого надання медичних послуг або медичної допомоги пацієнтам медичні фахівці повинні постійно навчатися. Саме через безперервну освіту протягом практичної діяльності медичні працівники удосконалюють власний професіоналізм.

На шляху досягнення стабільних результатів в організації БПР для України важливим є приєднання до міжнародного співтовариства організацій, які працюють у рамках БМО-БПР, шляхом впровадження нової системи акредитації, зокрема, акредитації провайдерів або організаторів БПР.

Впровадження акредитації провайдерів сприятиме приєднанню України до світового співтовариства БМО-БПР, досягненню суттевої еквівалентності міжнародним стандартам акредитованої освіти.

Автори заявляють про відсутність конфлікту інтересів. 


\section{REFERENCES/JITEPATУPA}

1. ACCME. (2020). Standards for Integrity and Independence in Accredited Continuing Education. Accreditation Council for Continuing Medical Education (ACCME). USA. Accessed 16 December 2020. URL: https://accme.org/accreditation-rules/standards-for-integrity-independence-accredited-ce.

2. Cabinet of Ministers of Ukraine. (2019). On approval of the Regulations on the system of continuous professional development of healthcare professionals. Resolution of the Cabinet of Ministers of March 28: 302. As amended in accordance with the Resolution of the Cabinet of Ministers № 798 August 21, 2019 and № 1181 03.11.2021. Cited 2021 December 20. [Кабінет Міністрів України (2019). Про затвердження Положення про систему безперервного професійного розвитку фахівців у сфері охорони здоров'я. Постанова Кабінету Міністрів від 28 березня 2018 р. № 302. Зі змінами, внесеними згідно з Постанов КМ № 798 від 21.08.2019 та №1181 від 03.11.2021]. URL: https://zakon.rada.gov.ua/laws/show/302-2018-\%D0\%BF\#Text.

3. Cabinet of Ministers of Ukraine. (2021). On approval of the Regulations on the system of continuing professional development of medical and pharmaceutical workers. Resolution of the Cabinet of Ministers of June 14, 2021 № 302. Cited 2021 December 20. [Кабінет Міністрів України. (2021). Про затвердження Положення про систему безперервного професійного розвитку медичних та фармацевтичних працівниківю Постанова Кабінету Міністрів України від 14.07.2021 № 725]. URL: https://zakon.rada.gov.ua/laws/show/302-2018-\%D0\%BF\#Text.
4. International Academy for CPD Accreditation. (2020). Standards for Substantive Equivalency between Continuing Professional Development/Continuing Medical Education (CPD/CME) Accreditation Systems. Cited 2021 December 20. URL: https://academy4cpdaccreditation.files.wordpress.com/2020/10/final_iacpda_standards_for_substantive_equivalency_10072020.pdf.

5. Marushko RV. (2020). Implementation of provider accreditation in Ukraine: the role and responsibilities of providers in continuing medical education/continuing professional developmentю. Modern Pediatrics. Ukraine. 4 (108): 7-13. [Марушко РВ. (2020). Стандарти істотної еквівалентності між системами акредитації безперервного професійного розвитку. Сучасна педіатрія. Україна. 4 (108): 7-13]. doi: 10.15574/SP.2020.108.7.

6. Marushko RV. (2020). Standards of substantive equivalence between accreditation systems for continuous professional development. Ukrainian Journal of Perinatology and Pediatrics. 3 (83): 7-15. [Марушко РВ. (2020). Впровадження акредитації провайдерів в Україні: роль та обов'язки провайдерів безперервного професійного розвитку. Український журнал Перинатологія і Педіатрія. 3 (83): 7-15]. doi: 10.15574/PP.2020.83.7.

7. Marushko RV. (2020). Standards for Integrity and Independence in Accredited Continuing Education. Modern Pediatrics. Ukraine. 7 (111): 7-13. [Марушко РВ. (2020). Стандарти доброчесності та незалежності в акредитованій безперервній освіті. Сучасна педіатрія. Україна: 7-13]. doi: 10.15574/SP.2020.111.7.

\section{Відомості про авторів:}

Марушко Ростислав Володимирович - д.мед.н., зав. науково-організаційним відділенням ДУ «ІПАГ імені академіка О.М. Лук'янової НАМН України». Адреса: м. Київ, вул. П. Майбороди, 8. https://orcid.org/0000-0001-7855-1679

Бахтіярова Дана Олегівна - директор ТОВ «Група компаній Мед Експерт». Адреса: м. Київ, вул. Межигірська, 19. тел. (044) 498-08-80.

Клай Світлана Русланівна - ТОВ «Група компаній Мед Експерт». Адреса: м. Київ, вул. Межигірська, 19; тел. (044) 498-08-80.

Загороднюк Дар'я Михайлівна - ТОВ «Група компаній Мед Експерт». Адреса: м. Київ, вул. Межигірська, 19; тел. (044) 498-08-80

Стаття надійшла до редакції 08.10.2021р., прийнята до друку 09.11.2021 р.

\section{УВАГА!}

Передплатити журнал «Сучасна педіатрія. Україна» можна в будь-якому відділенні $\ll$ Крппошти».

Передплатний індекс журналу «СУЧАСНА ПЕДІАТРІЯ. УКРАЇНА» - 09850 
Т.П. Борисова', О.Ю. Оболонська', ${ }^{1,2}$ Т.К. Мавропуло', Л.П. Бадогіна', Д.Г. Волков²

\title{
Особливості ренального кровотоку при гострому пошкодженні нирок у недоношених новонароджених дітей з гемодинамічно значущою відкритою артеріальною протокою
}

\author{
'Дніпровський державний медичний університет, Україна \\ КП «Дніпропетровська обласна дитяча клінічна лікарня» ДОР», м. Дніпро, Україна
}

Modern Pediatrics. Ukraine. (2021). 7(119): 14-18. doi 10.15574/SP.2021.119.14

For citation: Borysova TP, Obolonska OYu, Mavropulo TK, Badogina LP, Volkov DG. (2021). Features of renal blood flow in acute kidney injury in premature infants with hemodynamically significant patent ductus arteriosus. Modern Pediatrics. Ukraine. 7(119): 14-18. doi 10.15574/SP.2021.119.14.

Гемодинамічно значуща відкрита артеріальна протока (ГЗВАП) у недоношених новонароджених призводить до гіпоперфузії нирок у зв'язку з феноменом «обкрадання» великого кола кровообігу, що може спричинити розвиток гострого пошкодження нирок (ГПН). Застосування ультразвукової допплерографії судин нирок може надати ефективну допомогу в оцінці ренального кровотоку та ранній діагностиці ГПн.

Мета - оцінити прогностичну значущість стану ренального кровотоку на першу добу життя в недоношених новонароджених із ГЗВАП у ранній діагностиці ГПН.

Матеріали та методи. Обстежено 40 недоношених новонароджених (гестаційний вік - 29-36 тижнів) із ГЗВАП. Розподіл обстежених: група з ГПН 23 дитини, група без ГПН - 17 дітей. Період спостереження - 10 діб. Пацієнтам проведено ехокардіографрію з допплерометрією за допомогою широкосмугового мікроконвексного датчика з частотою 5-8 МГц («TOSHIBA» Nemso XG) на 5-11-ту годину життя. Кольорове ультразвукове допплерівське сканування судин нирок виконано на 1, 3 та 10-ту добу життя. Вивчено параметри кровотоку на магістральній та інтерлобарній ниркових артеріях: пікова систолічна швидкість (PSV) та кінцева діастолічна швидкість (EDV) кровотоку, індекс резистентності (RI). Діагностика та стратифрікація ступеня тяжкості ГПН відповідали критеріям неонатальної модифікації KDIGO.

Результати. На 3-5-ту добу життя ГПН діагностовано у 23 (57,5\%) дітей, але вже на 1-шу добу в них порівняно 3 пацієнтами без ГПН відмічено суттєве

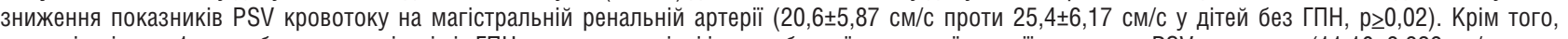

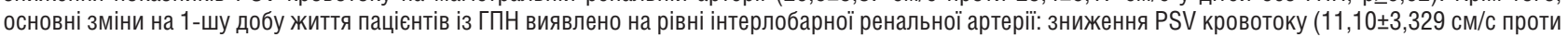

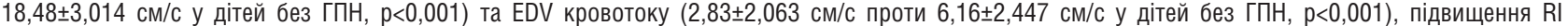

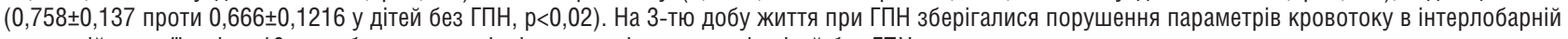
ренальній артерії, які на 10-ту добу життя не відрізнялися від показників дітей без ГПН.

Висновки. У недоношених новонароджених з ГЗВАП, яким на 3-5-ту добу життя діагностовано ГПН, на 1-шу добу виявлено зниження показників PSV кровотоку на магістральній ренальній артерії, зміни кровотоку на інтерлобарній ренальній артерії: зниження PSV та EDV кровотоку, підвищення RI. Отже, оцінка стану кровотоку в інтерлобарній ренальній артерії на 1-шу добу життя в недоношених новонароджених 3 ГЗВАП має діагностичне значення для своєчасного визначення групи ризику розвитку ГПН.

Дослідження виконано відповідно до принципів Гельсінської декларації. Протокол дослідження ухвалено Локальним етичним комітетом усіх зазначених у роботі установ. На проведення досліджень отримано інформовану згоду батьків дітей.

Автори заявляють про відсутність конфлікту інтересів.

Ключові слова: недоношені діти, відкрита артеріальна протока, ренальний кровотік, гостре пошкодження нирок.

\section{Features of renal blood flow in acute kidney injury in premature infants}

\section{with hemodynamically significant patent ductus arteriosus}

T.P. Borysova', O.Yu.Obolonska, ${ }^{1,2}$ T.K. Mavropulo', L.P. Badogina', D.G Volkov ${ }^{2}$

'Dnipro State Medical University, Ukraine

${ }^{2} \mathrm{Ml}$ «Dnepropetrovsk Regional Children's Clinical Hospital» Dnepropetrovsk Regional Council», Dnipro, Ukraine

Hemodynamically significant patent ductus arteriosus (HSPDA) in premature infants leads to renal hypoperfusion due to the phenomenon of «stealing» of the systemic circulation, which can contribute to the development of acute kidney injury (AKI). The use of ultrasound Doppler sonography of the renal vessels can be effective in assessing renal blood flow and in the early diagnosis of acute renal failure.

Purpose - to assess the prognostic significance of the state of renal blood flow in the first day of life in premature infants with HSPDA in the early diagnosis of AKI.

Materials and methods. We examined 40 preterm infants (gestational age 29-36 weeks) with HSPDA. Distribution of the examined patients: the group with AKI 23 children, the group without AKI - 17 children. The observation period was 10 days. The patients underwent echocardiography with Doppler analysis using a broadband microconvex probe with a frequency of 5-8 MHz (TOSHIBA Nemso XG) at 5-11 hours of life. Color Doppler ultrasound scanning of renal vessels was performed on the first, third and tenth days of life. The parameters of blood flow in the main renal and interlobar renal arteries were studied: peak systolic velocity (PSV) and end diastolic velocity (EDV) of blood flow, resistance index (RI). Diagnosis and stratification of AKI severity met the KDIGO neonatal modification criteria.

Results. On the third to fifth day of life, AKI was diagnosed in $23(57.5 \%)$ children, but already in the first day of life, compared with patients without AKI, a significant decrease in PSV parameters of blood flow in the main renal artery was noted $(20.6 \pm 5.87 \mathrm{~cm} / \mathrm{sec}$ versus $25.4 \pm 6.17 \mathrm{~cm} / \mathrm{sec}$ in children without AKI, $\mathrm{p}<0.02)$. In addition, the main changes in the first day of life in patients with AKI were revealed at the level of the interlobar renal artery, namely: a decrease in PSV blood flow $(11.10 \pm 3.329 \mathrm{~cm} / \mathrm{sec}$ versus $18.48 \pm 3.014 \mathrm{~cm} / \mathrm{sec}$ in children without $A K I, p<0.001)$ and EDV of blood flow $(2.83 \pm 2.063 \mathrm{~cm} / \mathrm{sec}$ versus $6.16 \pm 2.447 \mathrm{~cm} / \mathrm{sec}$ in children without $\mathrm{AKI}, \mathrm{p}<0.001)$, increased $\mathrm{RI}(0.758 \pm 0.137$ versus $0.666 \pm 0.1216$ in children without $A K I, p<0.02)$. 0 n the third day of life at $\mathrm{AKI}$, there was a disorder in the parameters of blood flow in the interlobaric renal artery, the value of which on the tenth day of life did not differ from the parameters of children without AKI.

Conclusions. In premature infants with HSPDA, who were diagnosed with AKI on the third to fifth day of life, in the first day of life, there is a decrease in PSV blood flow parameters in the main renal artery, changes in blood flow in the interlobar renal artery, namely: a decrease in PSV and EDV blood flow, an increase in RI. Thus, the assessment of the state of blood flow in the interlobar renal artery on the first day of life in premature infants with HSPDA is of diagnostic value for the timely determination of the risk group for AKI.

The research was carried out in accordance with the principles of the Helsinki declaration. The study protocol was approved by the Local ethics committee of all participating institution. The informed consent of the patient was obtained for conducting the studies.

No conflict of interest was declared by the authors.

Key words: premature infants, patent ductus arteriosus, renal blood flow, acute kidney injury. 


\section{Особенности ренального кровотока при остром повреждении почек у недоношенных новорожденных детей с гемодинамически значимым открытым артериальным протоком \\ Т.П. Борисова', О.Ю. Оболонская',2, Т.К. Мавропуло', Л.П. Бадогина', Д.Г. Волков²}

'Днепровский государственный медицинский университет, Украина

${ }^{2}$ ПП «Днепропетровская областная детская клиническая больница» ДОС», г. Днепр, Украина

Гемодинамически значимый открытый артериальный проток (ГЗОАП) у недоношенных новорожденных приводит к гипоперфузии почек из-за феномена «обкрадывания» большого круга кровообращения, что может способствовать развитию острого повреждения почек (ОПП). Использование ультразвуковой допплерографии сосудов почек может оказать эффективную помощь в оценке ренального кровотока и ранней диагностике ОПН. Цель - оценить прогностическую значимость состояния ренального кровотока на 1-е сутки жизни у недоношенных новорожденных с ГЗОАП в ранней диагностике ОПП.

Материалы и методы. Обследованы 40 недоношенных новорожденных (гестационный возраст - 29-36 недель) с ГзВАП. Распределение обследованных пациентов: группа с ОПП - 23 ребенка, группа без ОПП - 17 детей. Период наблюдения - 10 суток. Пациентам проведена эхокардиография с допплерометрией при помощи широкополосного микроконвексного датчика с частотой 5-8 MГц (TOSHIBA Nemso XG) на 5-11-й час жизни. Цветное ультразвуковое допплеровское сканирование сосудов почек выполнено на 1, 3 и 10-е сутки жизни. Изучены параметрь кровотока на магистральной и интерлобарной почечных артериях: пиковая систолическая скорость (PSV) и конечная диастолическая скорость (EDV) кровотока, индекс резистентности (RI). Диагностика и стратификация степени тяжести оПП соответствовали критериям неонатальной модификации KDIGO.

Результаты. На 3-5-е сутки жизни ОПП диагностировано у 23 (57,5\%) детей, но уже на 1-е сутки жизни у них по сравнению с пациентами без ОПП отмечено существенное снижение показателей PSV кровотока на магистральной ренальной артерии $(20,6 \pm 5,87$ см/с против 25,4ะ6,17 см/с у детей без ОПП, $\mathrm{p}<0,02)$. Кроме того, основные изменения на 1-е сутки жизни у пациентов с ОПП выявлены на уровне интерлобарной ренальной артерии: снижение PSV кровотока $(11,10 \pm 3,329$ см/с против $18,48 \pm 3,014$ см/с у детей без ОПП, p<0,001) и EDV кровотока $(2,83 \pm 2,063$ см/с против $6,16 \pm 2,447$ см/с у детей без ОПП, р<0,001), повышение RI $(0,758 \pm 0,137$ против 0,666 $\pm 0,1216$ у детей без 0ПН, р<0,02). На 3-е сутки жизни при ОПП сохранялось нарушение параметров кровотока в интерлобарной ренальной артерии, значение которых на 10-е сутки жизни не отличались от показателей детей без ОПП.

Выводы. У недоношенных новорожденных с ГЗОАП, у которых на 3-5-е сутки жизни диагностировано ОПП, на 1-е сутки жизни отмечено снижение показателей PSV кровотока на магистральной ренальной артерии, изменение кровотока на интерлобарной ренальной артерии: снижение PSV и EDV кровотока, повышение RI. Таким образом, оценка состояния кровотока в интерлобарной ренальной артерии на 1-е сутки жизни у недоношенных новорожденных с ГЗОАП имеет диагностическое значение для своевременного определения группы риска развития ОПП.

Исследование выполнено в соответствии с принципами Хельсинкской декларации. Протокол исследования одобрен Локальным этическим комитетом всех участвующих учреждений. На проведение исследований получено информированное согласие родителей детей.

Авторы заявляют об отсутствии конфликта интересов.

Ключевые слова: недоношенные дети, открытый артериальный проток, ренальный кровоток, острое повреждение почек.

\section{Вступ}

Одним з етіологічних факторів гострого пошкодження нирок (ГПН) у недоношених новонароджених розглядається гемодинамічно значуща відкрита артеріальна протока (ГЗВАП) [7]. У цих дітей шунтування крові в протоці зліва-направо сприяє надмірній циркуляції крові в легенях і розвитку феномену «обкрадання» великого кола кровообігу, що призводить до гіпоперфузії органів, у тому числі нирок. Порушення ниркового кровообігу є фактором ризику розвитку ГПН [5-7]. Застосування неінвазивних інструментальних методів дослідження, зокрема, ультразвукової допплерографії судин нирок, можуть надати ефективну допомогу в оцінці ренального кровотоку і ранній діагностиці ГПН. Сучасні літературні дані не дають змоги скласти єдину думку щодо діагностичної можливості цього методу при ГПН у недоношених новонароджених із ГЗВАП.

Meта дослідження - оцінити прогностичну значущість стану ренального кровотоку на 1-шу добу життя в недоношених новонароджених із ГЗВАП у ранній діагностиці ГПН.

\section{Матеріали та методи дослідження}

Когортне, проспективне дослідження проведено у 2018-2019 рр. на базі відділення анестезіології та інтенсивної терапії новонароджених КП
«Дніпропетровська обласна дитяча клінічна лікарня» та схвалено комісією з медичної етики лікарні.

Критерії залучення: недоношені новонароджені в терміні гестації 29-36 тижнів із ГЗВАП, підписана інформована згода батьків на участь у дослідженні. Критерії вилучення: вроджені вади розвитку, внутрішньомозкові та внутрішньошлуночкові крововиливи III-IV ступеня, сепсис новонароджених, тяжка асфіксія в пологах, захворювання шкіри, затримка внутрішньоутробного розвитку.

Обстежено 40 недоношених новонароджених, які надійшли під спостереження на 1-шу добу життя. Вибуло з дослідження 6 дітей у зв'язку з розвитком критеріїв вилучення: внутрішньошлуночковий крововилив III-IV ступеня (4 дитини), сепсис новонароджених (2 дитини). Розподіл хворих проведено залежно від розвитку ГПН: група з ГПН -23 дитини, група без ГПН - 17 дітей. Клінічне обстеження та лікування недоношених новонароджених здійснено за загальноприйнятою методикою [8,9]. Для закриття артеріальної протоки 32 недоношеним дітям застосовано ібупрофен, 8 - рестриктивну інфузійну терапію [10].

Ехокардіографію з допплерометрією за допомогою широкосмугового мікроконвексного датчика з частотою 5-8 МГц («TOSHIBA» Nemso XG модель SSA-580A, Японія) виконано після 
Таблиия 1

Клінічна характеристика обстежених пацієнтів

\begin{tabular}{|c|c|}
\hline Показник & $\begin{array}{c}\text { Недоношені } \\
\text { з ГЗВАП, } n=40\end{array}$ \\
\hline 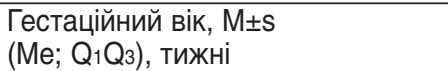 & $32,6 \pm 1,93(33 ; 32-34)$ \\
\hline 35-36 тиж, абс. (\%) & $7(17,5)$ \\
\hline 32-34 тиж, абс. (\%) & $24(60,0)$ \\
\hline 29-31 тиж, абс. (\%) & $9(22,5)$ \\
\hline 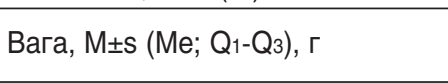 & $\begin{array}{c}2037,8 \pm 552,60 \\
(1950 ; 1620-2437,5)\end{array}$ \\
\hline$>2400$ г, абс. (\%) & $10(25,0)$ \\
\hline 1501-2400 г, абс. (\%) & $23(57,5)$ \\
\hline$\leq 1500$ г, абс. (\%) & $7(17,5)$ \\
\hline Хлопчики, абс. (\%) & $28(70,0)$ \\
\hline Дівчатка, абс. (\%) & $12(30,0)$ \\
\hline 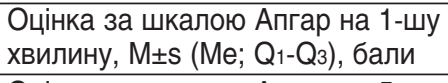 & $6,1 \pm 1,28(7 ; 5-7)$ \\
\hline $\begin{array}{l}\text { Оцінка за шкалою Апгар на 5-ту } \\
\text { хвилину, } \mathrm{M} \pm \mathrm{S}\left(\mathrm{Me} ; \mathrm{Q}_{1}-\mathrm{Q}_{3}\right), \text { бали }\end{array}$ & $6,8 \pm 1,04(7 ; 6-8)$ \\
\hline $\begin{array}{l}\text { Респіраторний } \\
\text { дистрес-синдром, абс. (\%) }\end{array}$ & $27(67,5)$ \\
\hline Ассріксія, абс. (\%) & $7(17,5)$ \\
\hline $\begin{array}{l}\text { Внутрішньоутробна } \\
\text { інфрекція, абс. (\%) }\end{array}$ & $6(15,0)$ \\
\hline $\begin{array}{l}\text { Розмір ВАП на 1-шу добу, } \\
\mathrm{M} \pm \mathrm{S}\left(\mathrm{Me} ; \mathrm{Q}_{1}-\mathrm{Q}_{3}\right), \mathrm{mм}\end{array}$ & $2,36 \pm 0,834(2,1 ; 1,7-2,7)$ \\
\hline $\begin{array}{l}\text { Розмір ВАП на 3-тю добу, } \\
M \pm S\left(M e ; Q_{1}-Q_{3}\right), \text { мм }\end{array}$ & $0,50 \pm 0,816(0 ; 0-1)$ \\
\hline
\end{tabular}

госпіталізації до відділення (5-11-та година життя), а далі - щодня для визначення відкритої артеріальної протоки (ВАП), її розміру та гемодинамічної значущості. Діаметр протоки виміряно під час кінцевої систоли в точці максимального звуження з використанням кольорового допплерівського потоку. Критерії ГЗВАП: великий розмір артеріальної протоки ( $\geq 1,5$ мм у новонароджених із масою тіла $<1500$ г, $>1,4$ мм/кг у новонароджених із масою тіла $\geq 1500$ г), шунтування крові зліва направо та зростаючий, пульсуючий кровоток у протоці, відношення розміру лівого передсердя до кореня аорти $>1,4$, високий діастолічний кровотік у легеневій артеpiï $>0,2$ м/c, ретроградний діастолічний кровотік у постдуктальному відділі спадної частини аорти, порушення регіонарного кровотоку [2].

Діагностику та стратифікацію ступеня тяжкості ГПН проведено за критеріями неонатальної модифікації KDIGO [12], для чого вивчено концентрацію сироваткового креатиніну та рівень діурезу.

Кольорове ультразвукове допплерівське сканування судинного русла нирок проведено на 1, 3 і 10-ту добу життя за допомогою мікроконвексного датчика 3 частотою 5-8 МГц («TOSHIBA» Nemso XG модель SSA-580A, Японія) у магістральній та інтерлобарній ренальних артеріях правої нирки, візуалізованих із бокової ділянки в положенні дитини на спині. Криві швидкості потоку отримано за оптимального кута огляду $\left(<50^{\circ}\right)$. Вивчено такі параметри ниркового кровотоку: пікову систолічну швидкість (PSV) кровотоку, кінцеву діастолічну швидкість (EDV) кровотоку, індекс резистентності (RI).

Для вирішення поставлених завдань і перевірки вихідних припущень використано комплекс статистичних методів дослідження: для незалежних вибірок - критерій Манна-Уітні та критерій Краскела-Уолліса, для оцінки динаміки - критерій знакових рангів Вілкоксона і критерій Макнемара. Перевірку на нормальність розподілу кількісних вибірок проведено з використанням критерію Колмогорова-Смірнова. Аналіз даних виконано за допомогою пакета статистичних програм IBM SPSS Statistics 23.

\section{Результати дослідження та їх обговорення}

Клінічну характеристику обстежених дітей наведено в таблиці 1. У розподілі за статтю виявлено істотне переважання хлопчиків. Гестаційний вік у середньому становив $32,6 \pm 1,93$ тижня, найчастіше - 32-34 тижні. Середня маса тіла при народженні дорівнювала 2037,8 $\pm 552,6$ г. Низьку масу тіла мали понад половина обстежених, дуже низьку масу тіла ( $\geq 1500$ г) майже кожна 6-та недоношена дитина. Респіраторний дистрес-синдром спостерігали в $67,5 \%$, асфіксію в пологах - у 17,5\%, внутрішньоутробну інфекцію - у 15,0\% дітей. Розмір ВАП на 1-шу добу становив у середньому $2,36 \pm 0,834$ мм, що пояснює її гемодинамічну значущість. На 3-тю добу життя розмір ВАП значно зменшився до $0,50 \pm 0,816$ мм.

На 3-тю добу життя ГПН діагностували у 21 (52,5\%) дитини, на 5-ту - ще у 2 (5,0\%) дітей, іх загальна кількість збільшилася до 23 (57,5\%). На 10-ту добу життя кількість дітей з ГПН зменшилася до 10 (29,4\%). Літературні дані також свідчать про вплив ГЗВАП на розвиток ГПН у недоношених новонароджених, але вказують на різну частоту ГПН: одні дослідники 30\% [5], інші - 41\% [13] і 49\% [7].

Стан ренального кровотоку проаналізували залежно від розвитку ГПН у недоношених дітей з ГЗВАП. PSV кровотоку на магістральній ренальній артерії була суттєво зниженою тільки на 1-шу добу життя в недоношених дітей з ГПН, ніж у дітей без ГПН (табл. 2). Цей факт підтверджує наявність гіпоперфузії нирок у дітей з ГЗВАП на 1-шу добу життя. У динаміці відмічали достовірне збільшення цього показника в усіх обстежени, а на 3 і 10-ту добу життя PSV кровотоку на магістральній ренальній 
Показники ренального кровотоку на магістральній ренальній артерії залежно

Таблиия 2 від гострого пошкодження нирок у недоношених новонароджених із гемодинамічно значущою відкритою артеріальною протокою, $\mathrm{M} \pm \mathrm{m}\left(\mathrm{Me} ; \mathrm{Q}_{1}-\mathrm{Q}_{3}\right)$

\begin{tabular}{|c|c|c|c|c|}
\hline Показник & Доба & ГПН немає, $\mathrm{n}=17$ (17) & ГПН є, n=23 (17) & $p<$ \\
\hline \multirow{3}{*}{ PSV, $\mathrm{cm} / \mathrm{c}$} & 1 & $25,4 \pm 6,17(24 ; 22-27,5)$ & $20,6 \pm 5,87(22 ; 16-23)$ & 0,02 \\
\hline & III & $28,6 \pm 5,32(29 ; 23-33)^{*}$ & $26,7 \pm 6,60(28 ; 22-32)^{\star \star \star}$ & $\mathrm{HC}$ \\
\hline & $X$ & $30,2 \pm 5,57(30 ; 26-35)^{\star \star *}$ & $30,5 \pm 4,85(32 ; 25-34)^{\star \star \star \wedge} \wedge$ & $\mathrm{HC}$ \\
\hline \multirow{3}{*}{$E D V, \mathrm{~cm} / \mathrm{c}$} & $\mathrm{I}$ & $6,6 \pm 3,08(6 ; 4,5-9)$ & $5,2 \pm 3,10(4 ; 2-8)$ & $\mathrm{HC}$ \\
\hline & III & $7,9 \pm 3,17(7 ; 5,5-9)$ & $7,1 \pm 3,95(6 ; 4-11)^{*}$ & $\mathrm{HC}$ \\
\hline & $X$ & $8,8 \pm 2,77(9 ; 6,5-11)^{*}$ & $6,9 \pm 2,03(7 ; 5,5-8)^{\star}$ & 0,04 \\
\hline \multirow{3}{*}{ RI } & $\mathrm{I}$ & $0,741 \pm 0,0921(0,74 ; 0,66-0,8)$ & $0,752 \pm 0,1256(0,79 ; 0,68-0,86)$ & $\mathrm{HC}$ \\
\hline & III & $0,725 \pm 0,0789(0,73 ; 0,68-0,8)$ & $0,723 \pm 0,1516(0,78 ; 0,61-0,86)$ & $\mathrm{HC}$ \\
\hline & $\mathrm{X}$ & $0,707 \pm 0,0877(0,7 ; 0,66-0,77)$ & $0,772 \pm 0,0636(0,78 ; 0,72-0,82)$ & 0,02 \\
\hline
\end{tabular}

Примітки: 1. Розмір вибірки на 10-ту добу наведено у дужках. 2. Під час порівняння незалежних вибірок застосовано критерій Манна-Уітні («нс» - значущої розбіжності не виявлено). 3. *, **, *** - значуща відмінність від рівня 1-ї доби; ^, ^^, ^^^ — від рівня 3-ї доби, відповідно р<0,05, $\mathrm{p}<0,01$ і р $<0,001$ за критерієм знакових рангів Вілкоксона.

артерії не відрізнялася залежно від наявності ГПН. EDV кровотоку в магістральній ренальній артерії на 1 і 3-тю добу життя між групами обстежених статистично не відрізнялася. Підвищення в динаміці EDV кровотоку в магістральній ренальній артерії на 10-ту добу в групі без ГПН було більш значним, ніж у дітей з ГПН, тому цей показник у дітей з ГПН став суттєво нижчим. RI на магістральній ренальній артерії був підвищеним тільки на 10-ту добу в дітей з ГПН порівняно з дітьми без ГПН.

Оцінка середніх значень основних гемодинамічних показників кровотоку на інтерлобарній ренальній артерії дала змогу виявити такі характеристики (табл. 3).

Пікова систолічна швидкість кровотоку на 1 і 3-тю добу життя була суттєво меншою в дітей з ГПН, ніж у групі без ГПН. У динаміці виявили достовірне збільшення цього показника в дітей з ГПН і на 10-ту добу життя PSV кровотоку на інтерлобарній ренальній артерії не мала істотних відмінностей залежно від ГПН.

Кінцева діастолічна швидкість кровотоку на інтерлобарній ренальній артерії була значно зниженою на 1 і 3-тю добу життя в дітей з ГПН. Слід зазначити, що показник EDV кровотоку на інтерлобарній ренальній артерії на 1-шу добу життя в дітей з ГПН був нижчим порівняно з групою без ГПН у 2,2 раза $(\mathrm{p}<0,001)$, на 3-тю - в 1,7 раза $(\mathrm{p}<0,001)$.

Значне зниження EDV кровоточу порівняно із PSV кровотоку на інтерлобарній ренальній артерії призвело до збільшення показника RI, який був значно вищим у пацієнтів із ГПН на 1 i 3-тю добу життя порівняно $з$ показниками дітей без ГПН. Тільки на 10-ту добу життя показники EDV кровотоку та RI на інтерлобарній ренальній артерії істотно не відрізнялися залежно від ГПН. Здатність перерозподіляти знижений кровотік шляхом зниження діастолічного тиску і спазму судин є одним із компенсаторних механізмів подолання гемодинамічних розладів, пов'язаних із ліво-правим шунтуванням крові при ГЗВАП [3,14], але надмірна вазоконстрикція може посилювати порушення оксигенації тканин.

Отже, основні гемодинамічні зміни за умови ГПН у недоношених новонароджених із ГЗВАП виявлено впродовж 1 і 3-ї доби життя

Таблиия 3

Показники ренального кровотоку на інтерлобарній ренальній артерії залежно від гострого пошкодження нирок у недоношених новонароджених із гемодинамічно значущою відкритою артеріальною протокою, $\mathrm{M} \pm \mathrm{m}\left(\mathrm{Me} ; \mathrm{Q}_{1}-\mathrm{Q}_{3}\right)$

\begin{tabular}{|c|c|c|c|c|}
\hline Показник & Доба & ГПН немає, n=17 (17) & ГПН $\epsilon, n=23(17)$ & $\mathbf{p}<$ \\
\hline \multirow{3}{*}{ PSV, cM/c } & $\mathrm{I}$ & $18,48 \pm 3,014(18,6 ; 16,35-20,9)$ & $11,10 \pm 3,329(11,3 ; 7,71-12)$ & 0,001 \\
\hline & III & $19,12 \pm 4,730(21 ; 16-22,5)$ & $15,57 \pm 4,541(16 ; 12-18)^{\star * *}$ & 0,02 \\
\hline & $\mathrm{X}$ & $22,71 \pm 5,882(24 ; 18,5-25,5)$ **^^ & $20,82 \pm 5,812(20 ; 17,5-23,5)^{\star \star \star \wedge \wedge}$ & $\mathrm{HC}$ \\
\hline \multirow{3}{*}{$\mathrm{EDV}, \mathrm{cm} / \mathrm{c}$} & $\mathrm{I}$ & $6,16 \pm 2,447(5,6 ; 4,75-7,7)$ & $2,83 \pm 2,063(2,2 ; 1,1-4,15)$ & 0,001 \\
\hline & III & $5,83 \pm 1,919(6 ; 4,5-7)$ & $3,48 \pm 1,532(3,1 ; 2-5)$ & 0,001 \\
\hline & $\mathrm{X}$ & $6,71 \pm 3,405(5 ; 4,5-8,5)$ & $4,65 \pm 2,644(4 ; 2,5-6,5)^{\star \star \wedge}$ & $\mathrm{HC}$ \\
\hline \multirow{3}{*}{$\mathrm{RI}$} & 1 & $0,666 \pm 0,1216(0,67 ; 0,6-0,74)$ & $0,758 \pm 0,137(0,8 ; 0,65-0,83)$ & 0,02 \\
\hline & III & $0,693 \pm 0,0869(0,7 ; 0,63-0,72)$ & $0,76 \pm 0,1588(0,82 ; 0,69-0,86)$ & 0,03 \\
\hline & $\mathrm{X}$ & $0,715 \pm 0,0937(0,72 ; 0,67-0,8)$ & $0,776 \pm 0,1127(0,8 ; 0,69-0,87)$ & $\mathrm{HC}$ \\
\hline
\end{tabular}

Примітки: 1.Розмір вибірки на 10-ту добу наведено в дужках. 2. Під час порівняння незалежних вибірок застосовано критерій Манна-Уітні («нс» - значущої розбіжності не спостерігалося). 3. *, **, *** - значуща відмінність від рівня 1-ї доби; ^, ^^, ^^^ — від рівня 3-ї доби, відповідно $\mathrm{p}<0,05, \mathrm{p}<0,01$ і $\mathrm{p}<0,001$ за критерієм знакових рангів Вілкоксона. 
на рівні інтерлобарної ренальної артерії: суттеве зниження показника пікової систолічної швидкості - на 40\%, кінцевої діастолічної швидкості кровотоку - на 50\%, підвищення індексу резистентності - на $14 \%$.

Порівнюючи отримані результати з даними літератури, можна виявити суперечності. Так, за результатами дослідження T. Bumelburg [1], у новонароджених із ГЗВАП зміни кровотоку найбільш виражені в магістральній нирковій артерії, але в цьому дослідженні були діти, які потребували хірургічного втручання щодо закриття артеріальної протоки. К.X. Hsu et al. [4] також виявили залежність між розміром ВАП і ризиком аномального показника ниркового кровотоку (95\% ДI: 1,6-39,4). Отримані нами дані співпали з даними літератури в тому, що RI є найбільш об'єктивним допплерометричним показником, який характеризує стан

\section{REFERENCES/JITEPATУPA}

1. Bumelburg T, Jorch G. (1989, Jun). Abnormal blood flow patterns in renal arteries of small preterm infants with patent ductus arteriosus detected by Doppler ultrasonography. Eur J Pediatr. 148(7): 660-664. doi: $10.1007 / B F 00441528$.

2. Boychenko AD, Gonchar MO, Kondratova II, Senatorova AV. (2015). Criteria for diagnostics of hemodynamically significant disseminated arterial duct in premature newborns. Neonatology, surgery and perinatal medicine. 1(5): 24-27. [Бойченко АД, Гончарь МО, Кондратова Ю, Сенаторова АВ. (2015). Критерії діагностики гемодинамічно значущої відкритої артеріальної протоки у недоношених новонароджених. Неонатологія, хірургія та перинатальна медицина. 1(5): 24-27]. doi: 10.24061/2413-4260.V.1.15.2015.

3. Capozzi G, Santoro G. (2011, Oct). Patent ductus arteriosus: patho-physiology, hemodynamic effects and clinical complications. $J$ Matern Fetal Neonatal Med. 24(1): 15-16. doi: 10.3109/14767058.2011.607564.

4. Hsu KH, Nguyen J, Dekom S, Ramanathan R, Noori S. (2020, Jan). Effects of Patent Ductus Arteriosus on Organ Blood Flow in Infants Born Very Preterm: A Prospective Study with Serial Echocardiography. J Pediatr. 216: 95-100. doi: 10.1016/j.jpeds.2019.08.057.

5. Jetton JG, Boohaker LJ, Sethi SK et al. (2017, Nov). Incidence and outcomes of neonatal acute kidney injury (AWAKEN): a multicentre, multinational, observational cohort study. Lancet Child Adolesc Health. 1(3): 184-194. doi: 10.1016/S2352-4642(17)30069-X.

6. Kusuda S, Kim TJ, Miyagi N et al. (1999). Postnatal change of renal artery blood flow velocity and its relationship with urine volume in very low birth weight infants during the first month of life. J Perinat Med. 27(2): 107-111. doi: 10.1515/JPM.1999.013.

7. Majed B, Bateman DA, Uy N, Lin F. (2019, Jun). Patent ductus arteriosus is associated with acute kidney injury in the preterm infant. Pediatr Nephrol. 34(6): 1129-1139. doi: 10.1007/s00467-019-4194-5. ренальної гемодинаміки, а його високі рівні свідчать про надмірну вазоконстрикцію [6,11].

\section{Висновки}

$\mathrm{y}$ недоношених новонароджених із ГЗВАП, яким на 3-5-ту добу життя діагностовано ГПН, на 1-шу добу відмічено зниження показників PSV кровотоку на магістральній ренальній артеpiï, суттєві зміни кровотоку на інтерлобарній ренальній артерії: зниження PSV та EDV кровотоку, підвищення RI. Отже, оцінка стану кровотоку в інтерлобарній ренальній артерії на 1-шу добу життя в недоношених новонароджених із ГЗВАП має діагностичне значення для своєчасного визначення групи ризику розвитку ГПН.

Джерела фінансування. Робота виконана власним коштом.

Автори заявляють про відсутність конфлікту інтересів.

8. Ministry of Health of Ukraine. (2006). Protocol of the medical look for the new narodzhena child with little masoyu tila at the time of the people. The order dated 29.08.2006. No.584. [MO3 України. (2006). Про затвердження Протоколу медичного догляду за новонародженою дитиною з малою масою тіла при народженні. Наказ від 29.08.2006 № 584]. URL: http://zakon.rada.gov.ua/rada/show/v0584282-06\#Text.

9. Ministry of Health of Ukraine. (2014). About the consolidation and implementation of medical and technological documents for the standardization of medical assistance from the ear, reanimation and development of medical assistance for newborns in Ukraine. The order dated 28.03.2014 No. 225. [МОЗ України. (2014). Про затвердження та впровадження медико-технологічних документів зі стандартизації медичної допомоги з початкової, реанімаційної і післяреанімаційної допомоги новонародженим в Україні. Наказ від 28.03.2014 № 225]. URL: https://z-I.com.ua/upload//moz\%20docs/225-1.pdf.

10. Obolonskyi A, Snisar V, Surkov D, Obolonska O. (2019, Jun). Management of patent ductus arteriosus in premature infants. Med perspekt. 18; 24(2): 33-40. doi: 10.26641/2307-0404.2019.2.170125.

11. Pokharel RP, Uetani Y, Tsuneishi S, Nakamura H. (1997, Feb). Neonatal renal artery blood flow velocities using color Doppler ultrasonography. Kobe J Med Sci. 43(1): 1-12. PMID: 9232953.

12. Selewski DT, Charlton JR, Jetton JG et al. (2015, Aug). Neonatal Acute Kidney Injury. Pediatrics. 136(2): e463-473. doi: 10.1542/ peds.2014-3819.

13. Stojanovic V, Barisic N, Milanovic B, Doronjski A. (2014). Acute kidney injury in preterm infants admitted to a neonatal intensive care unit. Pediatr. Nephrol. 29: 2213-2220. doi: 10.1007/s00467-014-2837-0.

14. Torigoe T, Sato S, Nagayama Y, Sato T, Yamazaki H. (2015, Jul). Influence of patent ductus arteriosus and ventilators on electrical velocimetry for measuring cardiac output in very-low/low birth weight infants. J Perinatol. 35(7): 485-489. doi: 10.1038/jp.2014.245.

Відомості про авторів:

Борисова Тамара Петрівна - д.мед.Н., проф., зав. каф. педіатрії 2 Дніпровського Дму. Адреса: м. Дніпро, вул. В. Вернадського, буд. 9. https://orcid. org/0000-0001-8347-4348. Оболонська Ольга Юріївна - д.філос., асистент каф. педіатрії 2 ДДМУ, лікар-неонатолог КП «Дніпропетровська обласна дитяча клінічна лікарня» ДОР».

Адреса: м. Дніпро, вул. В. Вернадського, буд. 9. https://orcid.org/0000-0001-9863-1828.

Мавропуло Тетяна Карлівна - д.мед.н., проф., зав. каф. педіатрії 3 та неонатології Дніпровського Дму. Адреса: м. Дніпро, вул. В. Вернадського,

Мавропуло Тетяна Карлівна - д.мед.н., проф.,
буд. 9. https://orcid.org/0000-0001-9351-3080.

буд. 9. https://orcid.org/0000-0001-9351-3080.

Волков Денис Георгійович - заст. мед. директора КП «Дніпропетровська обласна дитяча клінічна лікарня» ДОР». Адреса: м. Дніпро, вул. Космічна, буд.,

13. https://orcid.org/0000-0002-7838-5049.

Стаття надійшла до редакції 13.08.2021 р., прийнята до друку 09.11.2021 р. 


\title{
С.І. Ільченко, Т.В. Можейко, А.О. Фіалковська, Н.В. Мишина Результати добового моніторингу рівня пепсину в секреті ротової порожнини дітей раннього віку із синдромом регургітації
}

\author{
Дніпровський державний медичний університет, Україна \\ Modern Pediatrics. Ukraine. (2021). 7(119): 19-24. doi 10.15574/SP.2021.119.19 \\ For citation: Ilchenko SI, Mozheiko TV, Fialkovska AO, Mishina NV. (2021). The results of daily monitoring of salivary pepsin levels in young children with
} regurgitation syndrome. Modern Pediatrics. Ukraine. 7(119): 19-24. doi 10.15574/SP.2021.119.19.

Синдром регургітації в дітей раннього віку є одним із проявів гастроезофрагеального рефрлюксу (ГЕР), що може бути як віковим фізіологічним станом, так і патологічним із ризиком розвитку гастроезосрагеальної рефлюксної хвороби (ГЕРХ). Дифреренційна діагностика ГЕРХ у немовлят і дітей раннього віку ускладнюється через інвазивність і малодоступність рекомендованих діагностичних методів, зокрема, стравохідної рН-метрії. На сьогодні пошук нових неінвазивних і простих, але чутливих і специфічних, методів діагностики ГЕРХ у педіатричній практиці є актуальним та перспективним.

Мета - визначити динамічні закономірності рівня пепсину в секреті ротової порожнини дітей раннього віку в рамках добового моніторингу та залежно від клінічних проявів регургітації.

Матеріали та методи. Обстежено 55 дітей віком від 3 до 18 місяців, серед яких основну групу становили 38 дітей із видимим синдромом регургітації, а групу порівняння - 17 здорових дітей без клінічних проявів цього синдрому. Інтенсивність зригувань оцінено за п'ятибальною шкалою, рекомендованою міжнародними експертами «ESPGHAN». Для скринінгової діагностики патологічного ГEP у дітей застосовано ресрлюкс-анкету. Рівень пепсину визначено в секреті ротової порожнини тричі на добу методом імунодерментного аналізу («ELISA рерsin»). Статистичну обробку результатів дослідження проведено із застосуванням пакету програм «Statistica v.6.1».

Результати. За поточними скаргами синдром регургітації зафіксовано в усіх дітей основної групи. За результатами рефрюкс-анкети серед обстежених дітей отримано такі дані: половина (52,6\%) дітей не мали ознак ГЕР, можливий рефрлюкс був у $31,6 \%$ дітей, імовірний - у 15,8\% дітей. Результати добового моніторингу пепсину в слині дітей раннього віку показали, що його рівень був достовірно вищим у дітей з регургітацією, ніж у групі порівняння, як за середньодобовими значеннями, так і за проміжними показниками. Установлено, що максимальна активність пепсину в дітей основної групи була відразу після зригування та становила 446,8 (267,9-534,7) пг/мл. Вірогідних відмінностей між трьома зразками слини та середньодобовим показником пепсину в дітей основної групи не виявлено, що може свідчити про приховані епізоди ресрлюксу. У дітей з високим ризиком ГЕРХ, за даними рефлюкс-анкетування, достовірно вищим було значення пепсину натщесерце та його середньодобовий рівень, що має достатню специфічність і прогностичну цінність за результатами ROC-аналізу.

Висновки. Визначення рівня пепсину в дітей раннього віку може бути включене до скринінгових неінвазивних тестів для дисреренційної діагностики ГЕР Застосування цих тестів для прогнозування ризику позастравохідних ушкоджень потребує подальшого вивчення.

Дослідження виконано відповідно до принципів Гельсінської декларації. Протокол дослідження ухвалено Локальним етичним комітетом зазначеної в роботі установи. На проведення дослідження отримано інфрормовану згоду батьків дітей.

Автори заявляють про відсутність конфрлікту інтересів.

Ключові слова: регургітація, ГЕР, ГЕРХ, пепсин, діти.

\section{The results of daily monitoring of salivary pepsin levels in young children with regurgitation syndrome S.I. Ilchenko, T.V. Mozheiko, A.O. Fialkovska, N.V. Mishina \\ Dnipro State Medical University, Ukraine}

Regurgitation syndrome in infants is one of the manifestations of gastroesophageal reflux disease (GER), which can be both an age-related physiological condition and pathological one with the risk of gastroesophageal reflux disease (GERD) developing. Differential diagnosis of GERD in infants and young children is difficult due to invasiveness and low availability of the recommended diagnostic methods, in particular esophageal pH-metry. Today, the search for new non-invasive and simple, but sensitive and specific, methods for diagnosing GERD in pediatric practice is relevant and promising.

Purpose - to determine the dynamic patterns of the salivary pepsin level in young children within the framework of daily monitoring and depending on the clinical manifestations of regurgitation.

Materials and methods. 55 children from 3 to 18 months were examined, among them was 38 children with visible regurgitation syndrome and 17 healthy children without clinical manifestations of the regurgitation syndrome. The intensity of regurgitation was assessed using a five-point scale «ESPGHAN». A reflux questionnaire was used for screening diagnostics of pathological GER in children. Salivary pepsin level was determined three times a day by enzyme-linked immunosorbent assay (ELISA pepsin). Statistical processing was performed using «Statistica v.6.1» software package.

Results. Regurgitation syndrome was registered in all children of the main group according to their current complaints. The results of reflux questionnaire showed the following data: half of the children (52.6\%) had no signs of GER, possible reflux was revealed in $31.6 \%$ of children, and probable reflux was revealed in $15.8 \%$ of children. The results of daily monitoring of salivary pepsin level in infants showed that it was significantly higher in children with regurgitation than in control group, both in terms of average daily values and intermediate values. It was found that the maximum pepsin activity in children was immediately after regurgitation. There were no significant differences between the three saliva samples and the average daily pepsin index in the children of the main group, which may indicate the presence of latent episodes of reflux during the day. Children with a high risk of GERD according to the reflux questionnaire had significantly higher values of salivary pepsin on an empty stomach and its average daily level, which has sufficient specificity and predictive value according to the ROC analysis results.

Conclusions. Determination of salivary pepsin levels in infants can be included in screening noninvasive tests for the GER diagnosis. The use of these tests to predict the risk of extraesophageal damage requires further study.

The research was carried out in accordance with the principles of the Helsinki Declaration. The study protocol was approved by the Local Ethics Committee of the participating institution. The informed consent of the patient was obtained for conducting the studies.

No conflict of interest was declared by the authors.

Key words: regurgitation, GER, GERD, pepsin, children. 


\section{Результаты суточного мониторинга уровня пепсина в секрете ротовой полости детей раннего возраста с синдромом регургитации \\ С.И. Ильченко, Т.В. Можейко, А.А. Фиалковская, Н.В. Мишина}

Днепровский государственный медицинский университет, Украина

Синдром регургитации у детей раннего возраста является одним из проявлений гастроэзосрагеального ресрлюкса (ГЭР), что может быть как возрастным физиологическим состоянием, так и патологическим с риском развития гастроэзофрагеальной рефрлюксной болезни (ГЭРБ). Диффференциальная диагностика ГЭРБ у грудных детей и детей раннего возраста осложнена из-за инвазивности и малодоступности рекомендованных диагностических методов, в частности, пищеводной рН-метрии. На сегодняшний день поиск новых неинвазивных и простых, но чувствительных и специфических, методов диагностики ГЭРБ в педиатрической практике является актуальным и перспективным.

Цель - определить динамические закономерности уровня пепсина в секрете ротовой полости детей раннего возраста в рамках суточного мониторинга и в зависимости от клинических проявлений регургитации.

Материалы и методы. Обследованы 55 детей в возрасте от 3 до 18 месяцев, среди которых основную группу составили 38 детей с видимым синдромом регургитации, а группу сравнения - 17 здоровых детей без клинических проявлений данного синдрома. Интенсивность срыгивания оценена по пятибалльной шкале, рекомендованной международными экспертами «ESPGHAN». Для скрининговой диагностики патологического ГЭР у детей использована ресрлюкс-анкета. Уровень пепсина определен в секрете полости рта трижды в течение дня методом иммуноферментного анализа («ELISA pepsin»). Статистическая обработка результатов исследования проведена с использованием пакета программ «Statistica v.6.1».

Результаты. По текущим жалобам синдром регургитации засриксирован у всех детей основной группы. По результатам рефрлюкс-анкеты среди обследованных детей получены следующие данные: у половины (52,6\%) детей не выявлены признаки ГЭР, возможный рефлюкс был у $31,6 \%$ детей, а вероятный у 15,8\% детей. Результаты суточного мониторинга пепсина в секрете ротовой полости детей раннего возраста показали, что уровень был достоверно выше у детей с регургитацией, чем в группе сравнения, как по среднесуточным значениям, так и по промежуточным показателям. Установлено, что максимальная активность пепсина у детей основной группы выявлена сразу после срыгивания. Достоверные различия между тремя образцами слюны и среднесуточным показателем пепсина у детей основной группы не выявлены, что может свидетельствовать о наличии скрытых эпизодов ресрлюкса в течение суток. У детей с высоким риском ГЭРБ, по данным рефлюкс-анкетирования, было достоверно выше значение пепсина натощак и его среднесуточный уровень, что имеет достаточную специфичность и прогностическую ценность по результатам ROC-анализа.

Выводы. Определение уровня пепсина в слюне у детей раннего возраста может быть включено в скрининговые неинвазивные тесты для дисфференциальной диагностики ГЭР. Использование этих тестов для прогнозирования риска внепищеводных повреждений требует дальнейшего изучения.

Исследование выполнено в соответствии с принципами Хельсинкской декларации. Протокол исследования одобрен Локальным этическим комитетом участвующего учреждения. На проведение исследования получено инсрормированное согласие родителей детей.

Авторы заявляют об отсутствии консрликта интересов.

Ключевые слова: регургитация, ГЭР, ГЭРБ, пепсин, дети.

\section{Вступ}

инндром регургітації в дітей раннього віку є одним із проявів гастроезофагеального рефлюксу (ГЕР), що може бути як віковим фізіологічним станом, так і патологічним із ризиком розвитку гастроезофагеальної рефлюксної хвороби (ГЕРХ) [5]. Важливу роль у розвитку та прогресуванні ГЕРХ відіграє саме якісний склад рефлюксату, кількість у ньому соляної кислоти, пепсину, жовчних кислот та інших інгредієнтів. У новонароджених дітей переважає лужний рефлюксат. Соляна кислота та активований пепсин як фактор агресії набувають значення в більш старшому віці [13]. Клінічні прояви ГЕРХ у немовлят і дітей раннього віку вкрай варіабельні та неспецифічні [3]. Це може призвести як до неадекватної діагностики, так і до необгрунтованого лікування [5]. Відсутність «золотого стандарту» діагностики ГЕРХ істотно ускладнює встановлення діагнозу. Диференційна діагностика в цьому віці ускладнюється через інвазивність і малодоступність рекомендованих діагностичних методів, зокрема, стравохідної рН-метрії. Крім того, на думку багатьох експертів, стравохідна рН-метрія недостатньо інформативна в дітей раннього віку: чутливість методу становить 54\%, а специфічність - 71\%; рН-моніторинг не чутливий у разі слабокислого або лужних рефлюксів [12]. Імпедансометрія у поєднанні з рН-метрією дає змогу зафіксувати як кислотний, так і некислотний рефлюкс, але метод є високовартісним, i таке дослідження доступне лише в деяких медичних центрах. Аналіз результатів імпедансометрії потребує часу та досвіду. Серед показань до проведення рН-імпедансометрії $€$ оцінка взаємозв'язку стійких симптомів, що спричиняють занепокоєння дитини, з кислотним і некислотним ГЕР; визначення ролі кислотного та некислотного рефлюксу в розвитку езофагіту та виникненні інших симптомів, характерних для ГЕРХ [11].

На сьогодні цікавим із наукових і практичних позицій є дослідження вмісту пепсину в слині як потенційно неінвазивного маркера рефлюкс-аспірації в дітей з ГЕРХ. Через те, що фермент пепсин у нормі утворюється головними клітинами шлунка, його наявність у слині є безперечним доказом того, що відбувся рефлюкс, який досяг ротоглотки [2,13]. Деякі зарубіжні дослідження показали, що виявлення пепсину в харкотинні та/або слині можна розглядати як чутливий, неінвазивний метод діагностики проксимального рефлюксу шлункового вмісту або ларингофарингеального рефлюксу, але діагностичні значення його різняться 
$[9,10]$. Зокрема, проведено порівняння пепсину слини та даних 24-годинного моніторингу pH-імпедансометрії в педіатричних пацієнтів [2]. Частота пепсин-позитивних зразків суттєво корелювала з індексом симптомів і динамічними ознаками інструментального тестування. Автори дослідження вважають, що визначення режиму оптимального збору слини може допомогти досягти мети застосування пепсину слини як біомаркера орофарингеального рефлюксу. Крім того, вивчається роль самого пепсину як причини локального хронічного запалення. Пепсин зазвичай не активний поза шлунком, оскільки активується тільки в кислому середовищі при рН 2,0 [7]. Проте нещодавні дослідження припускають, що пепсин може призводити до пошкодження слизової оболонки гортані при некислотному рефлюксі. Існуючі дані вказують на те, що пепсин активно транспортується в епітеліальні клітини гортані і залишається там стабільним при $\mathrm{pH}$ 7,4, але незворотно інактивується при $\mathrm{pH}$ 8. Він впливає на клітини гортані та внутрішньоклітинні компартменти, такі як апарат Гольджі та лізосоми, через низьке значення їх рH (5,0 і 4,0 відповідно). Під впливом пепсину відбувається дилатація клітини, що є маркером як ГЕРХ, так і ларингофарингіального рефлюксу [1]. При значенні pH 6,8 пепсин, що довго перебуває в тканинах гортані, може активуватися при наступних епізодах рефлюксу або при надходженні іонів водню з інших джерел, включаючи їжу [4].

Отже, на сьогодні пошук нових неінвазивних і простих, але чутливих і специфічних, методів діагностики ГЕРХ у педіатричній практиці $\epsilon$ актуальним та перспективним.

Mema дослідження - визначити динамічні закономірності рівня пепсину в секреті ротової порожнини дітей раннього віку в рамках добового моніторингу та залежно від клінічних проявів регургітації.

\section{Матеріали та методи дослідження}

Обстежено 55 дітей віком від 3 до 18 місяців, серед яких основну групу становили 38 дітей із видимим синдромом регургітації (середній

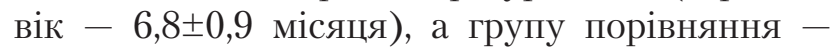
17 здорових дітей без клінічних проявів цього синдрому (середній вік $-5,7 \pm 0,3$ місяця). Критеріями вилучення були: гострі запальні захворювання шлунково-кишкового тракту (ШКТ), його вроджена патологія (пілоростеноз, атрезія стравоходу, вроджена діафрагмальна кила), тяжкі органічні ураження центральної нервової системи, що супроводжуються дисфагією. У дослідженні проведено детальний збір анамнезу та об'єктивне обстеження дітей. У дітей основної групи інтенсивність зригувань оцінено за п'ятибальною шкалою, рекомендованою міжнародними експертами «ESPGHAN» [http://www/http://espghan.org/guidelines]. Для скринінгової діагностики патологічного ГЕР у дітей застосовано рефлюкс-анкету з доведеною високою чутливістю і специфічністю [8]. Рівень пепсину визначено в секреті ротової порожнини тричі на добу: у дітей основної групи - натщесерце, відразу після зригування та за 1 годину після годування; у дітей групи порівняння - натщесерце, за півгодини до вживання їжі та за 1 годину після годування. В отриманих зразках об'ємом 1 мл визначено активність пепсину методом імуноферментного аналізу за допомогою наборів «Human Pepsin Elisa Kit» (виробництво «Elabscience», США). Чутливість методу: мінімальна концентрація пепсину, що визначається - 37,50 пг/мл, діапазон виявлення - 62,50-4000 пг/мл. Специфічність методу: визначає природний і рекомбінантний пепсин людини. Одночасно з моніторингом пепсину визначено $\mathrm{pH}$ слини, для чого використано індикаторні тест-смужки для визначення рН в діапазоні 0-14 з точністю (шагом вимірювання) $\mathrm{pH}$ 0,5.

Дослідження виконано відповідно до принципів Гельсінської декларації. Протокол дослідження погоджено Локальним етичним комітетом для всіх, хто брав участь. На проведення досліджень отримано інформовану згоду батьків дітей або їхніх опікунів.

Статистичну обробку результатів дослідження проведено із застосуванням пакету програм «Statistica v.6.1» (серійний номер AGAR909E415822FA). Оцінено кількісні та якісні показники. Для кількісних параметрів виконано перевірку на відповідність закона Гауса за критерієм Колмогорова-Смірнова з виправленням Ліллєфорса і Шапіро-Уілка. У разі розподілу, що відрізнявся від нормального, застосовано непараметричні характеристики і методи аналізу: медіану (Ме), міжквартильний розмах (25-75\%). Відповідно оцінено значущість відмінностей показників: за допомогою Манна-Уітні (U). Наявність і щільність взаємозв'язків між досліджуваними параметрами встановлено за результатами кореляційного аналізу Спірмена (r). Результати прийнято статистично значущими при значеннях $\mathrm{p}<0,05$. 
Таблиия 1

Середні значення рівнів пепсину в дітей основної групи та групи порівняння

\begin{tabular}{|c|c|c|c|c|}
\hline \multicolumn{2}{|c|}{ Рівень пепсину, пг/мл } & Основна група $(\mathrm{n}=38)$ & Група порівняння $(n=17)$ & p \\
\hline \multirow{4}{*}{ 1-ша порція } & $\mathrm{M} \pm \mathrm{m}$ & $454,9 \pm 64,1$ & $28,5 \pm 21,1$ & \multirow{4}{*}{$p<0,001$} \\
\hline & Min-Max & $139,4-968,1$ & $0,0-359,4$ & \\
\hline & $\mathrm{Me}$ & 393,5 & 0,0 & \\
\hline & $25-75 \%$ & $257,7-615,3$ & $0,0-0,0$ & \\
\hline \multirow{4}{*}{ 2-га порція } & $\mathrm{M} \pm \mathrm{m}$ & $531,9 \pm 125,4$ & $25,2 \pm 20,1$ & \multirow{4}{*}{$p<0,001$} \\
\hline & Min-Max & $169,9-2542,8$ & $0,0-342,4$ & \\
\hline & $\mathrm{Me}$ & 446,8 & 0,0 & \\
\hline & $25-75 \%$ & $267,9-534,7$ & $0,0-0,0$ & \\
\hline \multirow{4}{*}{ 3-тя порція } & $\mathrm{M} \pm \mathrm{m}$ & $422,9 \pm 48,2$ & $31,7 \pm 21,1$ & \multirow{4}{*}{$p<0,001$} \\
\hline & Min-Max & $172,9-807,7$ & $0,0-356,4$ & \\
\hline & $\mathrm{Me}$ & 378,9 & 0,0 & \\
\hline & $25-75 \%$ & $247,1-581,2$ & $0,0-0,0$ & \\
\hline \multirow{4}{*}{ Середньодобовий рівень } & $\mathrm{M} \pm \mathrm{m}$ & $456,8 \pm 56,9$ & $28,5 \pm 11,6$ & \multirow{4}{*}{$p<0,001$} \\
\hline & Min-Max & $139,4-1183,8$ & $0,0-141,7$ & \\
\hline & $\mathrm{Me}$ & 398,1 & 0,0 & \\
\hline & $25-75 \%$ & $255,3-608,3$ & $0,0-28,7$ & \\
\hline
\end{tabular}

Для оцінювання діагностичної ефективності показників застосовано ROC-аналіз із визначенням площі під ROC-кривою (AUC), за результатом визначено якість діагностичної моделі. За допомогою порогового значення розраховано чутливість, специфічність, позитивну i негативну прогностичну цінність. Під час ROC-аналізу показників визначено оптимальні порогові значення для максимальної суми чутливості та специфічності.

\section{Результати дослідження та їх обговорення}

Аналіз даних первинної медичної документації показав, що в переважної більшості (у 28 дітей, або 73,7\%) дітей основної групи скарги на зригування з'явилися до 3-місячного віку, у $10(26,3 \%)$ дітей - після 3-місячного віку. Середня інтенсивність зригувань у дітей основної групи становила 1,5 $\pm 0,2$ балу. При цьому 24 (63,2\%) дитини мали 1 бал (менше 5 зригувань на добу об'ємом кожне $<3$ мл), 12 (31,6\%) дітей -2 бали (більше 5 зригувань на добу об'ємом кожне $\leq 3$ мл) і 6 (5,3\%) дітей -5 балів (зригування від 1/2 до повного обсягу їжі, введеної під час годування, не менш ніж у половині випадків годувань). Також батьки скаржилися на порушення сну дітей у $42,1 \%$ і занепокоєння у 26,3\% випадків. За результатами рефлюкс-анкети серед обстежених дітей основної групи отримано такі дані: майже половина дітей не мали ознак ГЕР ( $\leq 6$ балів), можливий рефлюкс був у $12(31,6 \%)$ дітей (сума балів $7-9)$ та імовірний рефлюкс - у $6(15,8 \%)$ дітей (сума балів $-\geq 9$ ). Не виявлено вірогідних зв'язків між вираженістю синдрому зригування і характером вигодовування. Порушення в техніці годування відзначалися у $66,7 \%$ випадках, серед яких найчастіше фіксувалась аерофагія у $33,3 \%$, а також годування дитини в положенні лежачи - у 16,7\%. Функціональні розлади харчування в анамнезі спостерігалися в 34 (89,5\%) дітей. Скарги на кольки відмічалися в $63,2 \%$, діарея - у 26,3\%, закреп - у 26,3\% випадків. Установлено, що 16 (42,2\%) дітей піддавалися впливу пасивного тютюнокуріння з боку батьків, що $€$ також можливим тригером регургітаціііі.

У межах добового моніторингу секрету ротової порожнини на наявність пепсину в дітей проаналізовано 165 проб біоматеріалу. Тест був позитивним в $102(89,5 \%)$ із 114 проб в основній групі та тільки в $10(19,6 \%)$ iз 51 проби в групі порівняння. Рівень пепсину був достовірно вищим ( $<0,001)$ у дітей основної групи, ніж у групі порівняння, як за середньодобовими значеннями, так і за проміжними показниками (табл. 1).

Установлено, що максимальна активність пепсину в дітей основної групи була відразу після зригування та в середньому становила 446,8 $(267,9-534,7)$ пг/мл. Вірогідних відмінностей між трьома зразками слини та середньодобовим показником пепсину в дітей основної групи не виявлено $(454,9 \pm 64,1$ пг/мл, $531,9 \pm 125,4 \quad$ пг/мл, $422,9 \pm 48,2 \quad$ пг/мЛ і 456,8 $\pm 56,9$ пг/мл відповідно, p>0,05), що може свідчити про приховані епізоди рефлюксу протягом доби. За даними кореляційного аналізу встановлено вірогідний взаємозв'язок між рівнем пепсину після зригування та віком дитини $(\mathrm{r}=0,49, \mathrm{p}=0,04)$. Також виявлено взаємозв'язок 
між рівнем пепсину після вживання їжі із симптомами інших функціональних розладів харчування $(\mathrm{r}=0,59, \mathrm{p}=0,02)$ та пасивного тютюнокуріння $(r=0,49 ; \mathrm{p}=0,05)$.

У подальшому залежно від кількості набраних балів за рефлюкс-анкетою діти з основної групи були поділені на дві підгрупи: 1-ша підгрупа, яка отримала $\leq 6$ балів $(\mathrm{n}=20)$; 2-га підгрупа, яка отримала $\geq 7$ балів $(\mathrm{n}=18)$. Під час порівняння (рис.) встановлено, що діти 2-ї підгрупи мали достовірно вище значення пепсину натщесерце $(606,4)(367,0-909,8)$ пг /мл проти 257,7 (178,6-420,0) пг/мл; р<0,05) i середньодобовий його рівень (608,3 (463,5-653,3) пг/мл проти 360,7 (197,4-398,1) пг/мл; р<0,05). У цій підгрупі зустрічалися діти 3 дуже високим рівнем пепсину (1000 пг/мл) в окремих порціях слини.

Структура 1 і 2-ї підгруп за рівнем позитивних тестів (перший рівень $-<300$ пг/мл, другий рівень $-300-500$ пг/мл, третій рівень 500 пг/мл) також достовірно різнилася. Так, рівень пепсину в секреті ротової порожнини $<300$ пг/мл достовірно частіше зустрічався в дітей 1-ї підгрупи після зригування (60,0 $\pm 11,0 \%$ проти $\left.11,1 \pm 7,4 \% ; \chi^{2}=9,73, \mathrm{p}<0,05\right)$ та за 1 годину після вживання їжі $(60,0 \pm 11,0 \%$ проти $\left.22,2 \pm 9,8 \% ; \chi^{2}=5,55, \quad \mathrm{p}<0,05\right)$. Рівень пепсину 500 пг/мл достовірно частіше зустрічався в дітей 2-ї підгрупи в усіх трьох пробах слини (натщесерце - 55,6 $\pm 11,7 \%$ проти $10,0 \pm 6,7 \% ; \chi^{2}=9,10, \mathrm{p}<0,05$; після зригування $66,7 \pm 11,1 \%$ проти $20,0 \pm 8,9 \%, \chi^{2}=8,46, \mathrm{p}<0,05$; за 1 годину після вживання їжі $-44,4 \pm 11,7 \%$ проти $\left.10,0 \pm 6,7 \% ; \chi^{2}=5,80, \mathrm{p}<0,05\right)$, (табл. 2).

Під час визначення $\mathrm{pH}$ слини встановлено, що середньодобові показники були в межах $8,1 \pm 0,4$ у дітей основної групи. Не виявлено вірогідних відмінностей за середніми показниками $\mathrm{pH}$ між 1 і 2-ю підгрупами $(8,2 \pm 0,2$ проти $8,0 \pm 0,9$ відповідно; $\mathrm{p}>0,05)$, і це співпадає 3 даними інших дослідників щодо низької інформативності pH-метрії в дітей раннього віку та переважання в них лужного рефлюксату. Не

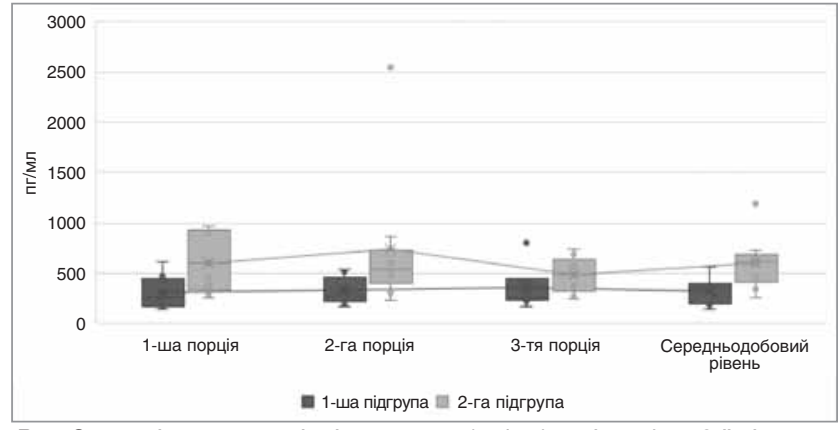

Рис. Середні значення рівнів пепсину (пг/мл) у дітей 1 та 2-ї підгруп

встановлено вірогідних кореляційних зв'язків між рівнем пепсину та $\mathrm{pH}$ слини ( $>00,05)$. Але у 27,8\% дітей 2-ї підгрупи зафіксовано значення $\mathrm{pH}<6,0$ під час добового моніторингу, що дає обгрунтування відносити їх до групи ризику, враховуючи факт активації пепсину в таких умовах за його накопичення в епітеліальних клітинах під час повторних ГЕР. Ці дані потребують подальшого вивчення та співвідношення 3 результатами вже існуючих досліджень, наприклад, щодо впливу пепсину на мукозальний імунітет.

За допомогою ROC-аналізу визначено оптимальне порогове значення рівня пепсину натщесерце у слині дітей для діагностики ГЕРХ 443,4 пг/мл. Отримано такі показники діагностичної цінності: чутливість - 66,7\%, специфічність - 80,0\%, прогностична цінність позитивного результату $-75,0 \%$, прогностична цінність негативного результату - 72,7\%, площа під кривою (AUC) - 0,844 (95\% ДІ 0,670-1,00).

\section{Висновки}

Результати добового моніторингу активності пепсину в секреті ротової порожнини дітей раннього віку показали, що його рівень був достовірно вищим у дітей з регургітацією, ніж у групі порівняння, як за середньодобовими значеннями, так і за проміжними показниками. Встановлено, що максимальна активність пепсину в дітей основної групи була відразу після зригування, вірогідних відмінностей між трьома зразками слини та середньодобовим

Таблиия 2

Розподіл дітей 1 та 2-ї підгруп за рівнем пепсину (\%)

\begin{tabular}{|l|c|c|c|c|c|c|}
\hline \multirow{2}{*}{ Рівень пепсину, пг/мл } & \multicolumn{2}{|c|}{$<\mathbf{3 0 0}$ пг/мл } & \multicolumn{2}{c|}{$\mathbf{3 0 0 - 5 0 0 ~ п г / м л ~}$} & \multicolumn{2}{|c|}{$\mathbf{5 0 0}$ пг/мл } \\
\cline { 2 - 7 } & $\begin{array}{c}\text { 1-ша } \\
\text { підгрупа }\end{array}$ & $\begin{array}{c}\text { 2-га } \\
\text { підгрупа }\end{array}$ & $\begin{array}{c}\text { 1-ша } \\
\text { підгрупа }\end{array}$ & $\begin{array}{c}\text { 2-га } \\
\text { підгрупа }\end{array}$ & $\begin{array}{c}\text { 1-ша } \\
\text { підгрупа }\end{array}$ & $\begin{array}{c}\text { 2-га } \\
\text { підгрупа }\end{array}$ \\
\hline Натщесерце & $50,0 \pm 11,2$ & $22,2 \pm 9,8$ & $40,0 \pm 11,0$ & $22,2 \pm 9,8$ & $10,0 \pm 6,7$ & $55,6 \pm 11,7^{*}$ \\
\hline Після зригування & $60,0 \pm 11,0^{*}$ & $11,1 \pm 7,4$ & $20,0 \pm 8,9$ & $22,2 \pm 9,8$ & $20,0 \pm 8,9$ & $66,7 \pm 11,1^{*}$ \\
\hline За 1 годину після вживання їжі & $60,0 \pm 11,0^{*}$ & $22,2 \pm 9,8$ & $30,0 \pm 10,3$ & $33,3 \pm 11,1$ & $10,0 \pm 6,7$ & $44,4 \pm 11,7^{*}$ \\
\hline
\end{tabular}

Примітка: * - p<0,05 між показниками 1 та 2-ї підгруп. 
показником пепсину в дітей основної групи не виявлено, що може свідчити про приховані епізоди рефлюксу протягом доби. У дітей з високим ризиком ГЕРХ за даними рефлюкс-анкетування було достовірно вище значення пепсину натщесерце та його середньодобовий рівень, що має достатню специфічність і прогностичну цінність за результатами ROC-аналізу. Отже, ви- значення пепсину в секреті ротової порожнини може бути включеним до скринінгових неінвазивних тестів для диференційної діагностики ГЕР у дітей раннього віку. Застосування цих тестів для прогнозування ризику позастравохідних ушкоджень потребує подальшого вивчення.

Автори заявляють про відсутність конфлікmy інтересів.

\section{REFERENCES/JITEPATYPA}

1. Campagnolo AM, Priston J, Thoen RH, Medeiros T, Assuncao AR. (2014, Apr). Laryngopharyngeal reflux: diagnosis, treatment, and latest research. Int Arch Otorhinolaryngol. 18 (2): 184-191. doi: $10.1055 / \mathrm{s}-0033-1352504$.

2. Fortunato JE, D'Agostino RB Jr, Lively MO. (2017, Feb). Pepsin in saliva as a biomarker for oropharyngeal reflux compared with 24-hour esophageal impedance/pH monitoring in pediatric patients. Neurogastroenterol Motil. 29: 2. doi: $10.1111 / \mathrm{nmo} .12936$.

3. Ilchenko SV, Mozheiko TV, Kramarenko NM, Duplenko NV. (2019). Clinical and functional portrait of infants with regurgitation syndrome. Child's Health. 14 (6): 8-14. [Ільченко Сl, Можейко ТВ, Крамаренко НМ, Дупленко НВ. (2019). Клініко-функціональний портрет дітей раннього віку з синдромом регургітації. Здоров'я дитини. $14(6): 8-14]$.

4. Maev IV, Selskaya JV, Andreev DN, Dicheva DT, Bogolepova ZN, Kuznetsova El. (2019). Laryngopharyngeal reflux: clinical significance, modern approaches to diagnosis and treatment. Meditsinskiy sovet=Medical Council. 3: 8-16. [Маев ИВ, Сельская ЮВ, Андреев ДН, Дичева ДТ, Боголепова ЗН, Кузнецова ЕИ. (2019). Ларингофарингеальный рефлюкс: клиническое значение, современные подходы к диагностике и лечению. Медицинский совет. 3: 8-16]. URL: https://doi.org/10.21518/2079-701X-2019-3-8-163.

5. Rosen R, Vandenplas Y, Singendonk M, Cabana M, DiLorenzo C, Gottrand F, Gupta S, Langendam M, Staiano A, Thapar N, Tipnis N, Tabbers M. (2018, Mar). Pediatric Gastroesophageal Reflux Clinical Practice Guidelines: Joint Recommendations of the North American Society for Pediatric Gastroenterology, Hepatology, and Nutrition and the European Society for Pediatric Gastroenterology, Hepatology, and Nutrition. J Pediatr Gastroenterol Nutr. 66 (3): 516-554. doi: 10.1097/ MPG.0000000000001889.

6. Shadrin $\mathrm{OH}$, Ihnatko LV. (2016). Suchasni pidkhody do diahnostyky ta likuvannia hastroezofahealnoi refliuksnoi khvoroby u ditei. Zdorovia Ukrainy. 3: 26-27. [Шадрін ОГ, Ігнатко ЛВ. (2016). Сучасні підходи до діагностики та лікування гастроезофагеальної рефлюксної хвороби у дітей. Здоров'я України. 3: 26-27].

7. Stanforth KJ, Wilcox MD, Chater PI, Brownlee IA, Zakhour MI, Banecki KMRM, Pearson JP. (2021). Pepsin properties, structure, and its accurate measurement: a narrative review. Ann Esophagus: 1-9. doi: $10.21037 /$ aoe-20-95
8. Starets EA, Truhalskaya WV. (2014). Using refluxxscreening questionnaire for screening diagnosis of pathological gastroesophageal reflux in children. Perinatologiya i pediatriya. 4 (60): 54-56. [Старец ЕA, Трухальская ВВ. (2014). Использование рефлюкс-анкеты для скрининговой диагностики патологического гастроэзофагеального рефлюкса у детей. Перинатология и педиатрия. 4 (60): 54-56]. doi 10.15574/PP.2014.60.54.

9. Strugala V, Woodcock AD, Dettmar PW, Faruqi S, Morice AH. (2016, Jan). Detection of pepsin in sputum: a rapid and objective measure of airways reflux. Eur Respir J. 47 (1): 339-341. doi: 10.1183/13993003.008272015.

10. Upendran $Y$, Leach ST, Singh H, McBride J, Thomas PS, Belessis $Y$, Krishnan U. (2020, Mar). Pepsin as a Marker of Reflux Aspiration in Children With Esophageal Atresia: A Pilot Study. Front Pediatr. 19 (8): 94 . doi: 10.3389/fped.2020.00094.

11. Vandenplas Y, Hauser B, Salvatore S. (2019). Diagnosis and management of gastroesophageal reflux disease in infants and children: from guidelines to clinical practice. Pediatrics. Consilium Medicum. 3: 14-23. [Ванденплас И, Хаузер Б, Сальваторе С. (2019). Диагностика и лечение гастроэзофагеальной рефлюксной болезни у младенцев и детей раннего возраста: от рекомендаций к клинической практике. Педиатрия. Consilium Medicum. 3: 14-23]. doi: 10.26442/26586630.2019.3.190438.

12. Zakharova IN, Sugyan NG, Pykov MI. (2014). Regurgitation syndrome in infants: diagnosis and management. Effective Pharmacotherapy. 3: 18-28. [Захарова ИН, Сугян НГ, Пыков МИ. (2014). Синдром срыгивания у детей раннего возраста: диагностика и коррекция. Эффективная фармакотерапия. 3: 18-28].

13. Zub RI, Bychkova SV, Bychkov MA. (2017). Content of sialic acid and pepsin in saliva and gastric juice of patients with diseases of stomach and esophagus. Fiziologichnyi Zhurnal. 63 (6): 99-105. [Зуб PI, Бичкова СВ, Бичков МА. (2017). Вміст сіалових кислот і пепсину у слині та шлунковому соку пацієнтів із захворюваннями шлунка і стравоходу. Фізіологічний журнал. 63 (6): 99-105]. URL: https://doi.org/10.15407/fz63.06.099.

14. Zubarenko AV, Kravchenko TY. (2013). Modern look to gastroesophageal reflux disease in children. Perinatologiya i pediatriya. 1 (53): 114-122. [Зубаренко ОВ, Кравченко ТЮ. (2013). Сучасний погляд на гастроезофагеальну рефлюксну хворобу у дітей. Перинатология и педиатрия. 1 (53): 114-122].

\section{Відомості про авторів:}

Ільченко Світлана Іванівна - д.мед.н., проф. каф. пропедевтики дитячих хвороб Дніпровського Дму. Адреса: м. Дніпро, вул. В. Вернадського, 9. https://orcid.org/00Ні00-0003-2181-1833. Мишина Наіра Валеріївна - к.мед.н., доц. каф. пропедевтики дитячих хвороб Дніпровського ДмУ. Адреса: м. Дніпро, вул. В. Вернадського, 9. https://orcid.org/0000-0001-6720-8939. Фіалковська Анастасія Олександрівна - к.мед.н., доц. каф. пропедевтики дитячих хвороб Дніпровського ДмУ. Адреса: м. Дніпро,

вул. В. Вернадського, 9. https://orcid.org/0000-0001-6004-8418.

Можейко Тетяна Вадимівна - очний аспірант каф. пропедевтики дитячих хвороб Дніпровського Дму. Адреса: м. Дніпро, вул. В. Вернадського, 9.

Стаття надійшла до редакції 03.08.2021 р., прийнята до друку 09.11.2021 р. 
Н.В. Воробйова

\title{
Фактори впливу на виразність клініко-лабораторних проявів синдрому мальабсорбції вуглеводів у дітей раннього віку з ротавірусною інфекцією
}

\author{
Запорізький державний медичний університет, Україна
}

Modern Pediatrics. Ukraine. (2021). 7(119): 25-33. doi 10.15574/SP.2021.119.25

For citation: Vorobiova NV. (2021). Influencing factors on the severity of clinical and laboratory manifestations of carbohydrate malabsorption syndrome in early-aged children with rotavirus infection. Modern Pediatrics. Ukraine. 7(119) : 25-33. doi 10.15574/SP.2021.119. 25.

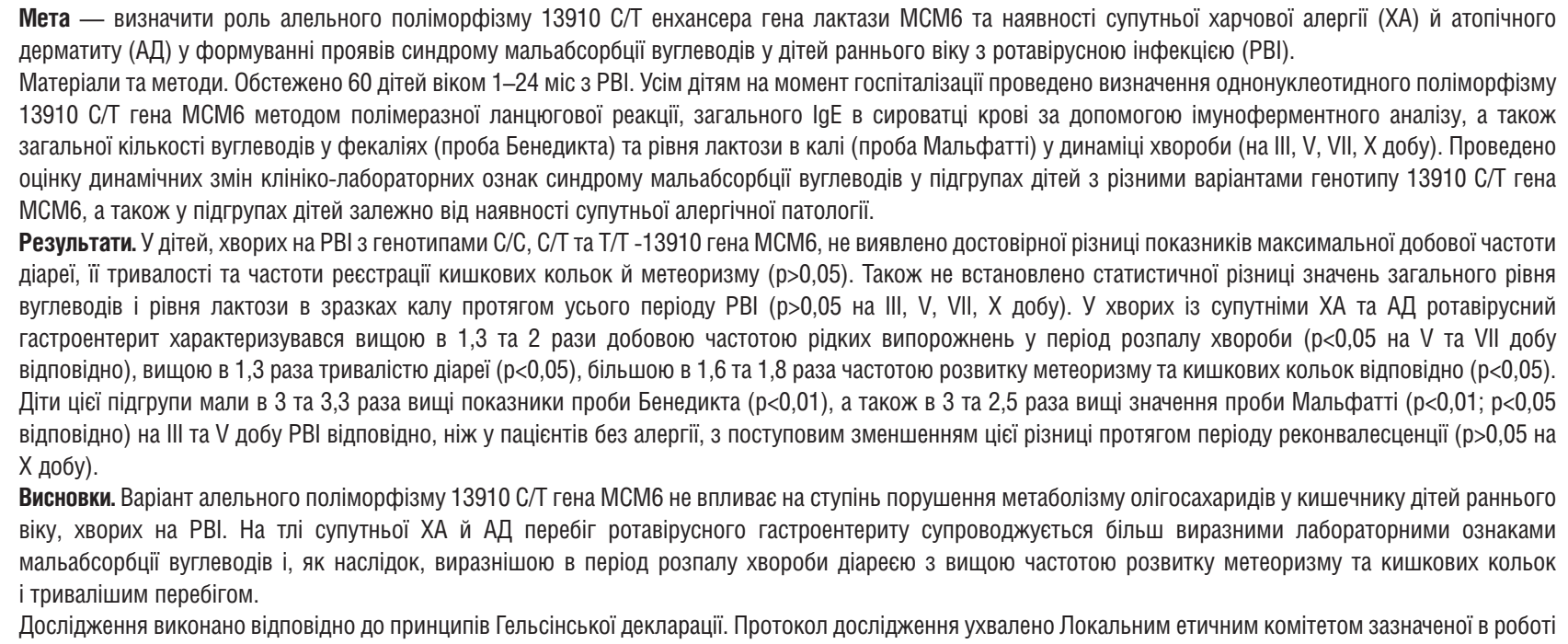
Дослідження виконано відповідно до принципів Гельсінської декларації. Протокол дос

Автор заявляє про відсутність конфрлікту інтересів.

Ключові слова: ротавірусна інфекція, діти раннього віку, синдром мальабсорбції вуглеводів, поліморфізм гена лактази, харчова алергія, атопічний дерматит.

\author{
Influencing factors on the severity of clinical and laboratory manifestations of carbohydrate malabsorption \\ syndrome in early-aged children with rotavirus infection \\ N.V. Vorobiova \\ Zaporizhzhia State Medical University, Ukraine
}

Purpose - to determine the role of the lactase gene MCM6 allelic polymorphism $13910 \mathrm{C} / \mathrm{T}$ and the concomitant food allergy (FA) and atopic dermatitis (AD) on the formation of carbohydrate malabsorption syndrome manifestations in early-aged children with rotavirus infection (RVI).

Materials and methods. 60 children aged 1-24 months with RVI were examined. The determination of single nucleotide polymorphism $13910 \mathrm{C} / \mathrm{T}$ of the MCM6 gene was performed by real-time polymerase chain reaction and the content of total Ig $E$ in serum was determined by enzyme immunoassay for all children on the day of hospitalization. Total amount of carbohydrates in feces (Benedict's test) and the level of lactose in feces (Malfatti's test) were also determined in the dynamics of the disease (on the 3rd, 5th, 7th, 10th day). The analysis of the carbohydrate malabsorption syndrome clinical and laboratory signs was carried out in subgroups depending on the genotype $13910 \mathrm{C} / \mathrm{T}$ of the MCM6 gene and concomitant allergic pathology.

Results. No significant differences were found in the maximum daily frequency of diarrhea, its duration and the frequency of intestinal colic and flatulence registration in children with genotypes $C / C, C / T$ and $T / T-13910$ of the MCM6 gene $(p>0.05)$. There was no statistically significant difference in the total level of carbohydrates and lactose in feces at all stages of the disease ( $p>0.05$ on the 3rd, 5th, 7th, 10th). Children with concomitant FA and AD had 1.3 and 2 times higher daily frequency of liquid bowel movements during the height of the disease ( $p<0.05$ on the 5 th and 7 th days, respectively), 1.3 times longer diarrhea $(p<0.05), 1.6$ and 1.8 times higher incidence of flatulence and intestinal colic $(p<0.05)$. These children had 3 and 3.3 times higher Benedict's test values $(p<0.01)$, as well as 3 and 2.5 times higher Malfatti's test values $(p<0.01 ; p<0.05$, respectively) on the 3rd and 5th days of RVI, respectively, than in patients without allergies, with a gradual decrease in this difference during the period of convalescence ( $p>0.05$ on the 10 th day).

Conclusions. The allelic polymorphism $13910 \mathrm{C} / \mathrm{T}$ of the MCM6 gene does not affect the degree of oligosaccharide metabolism disorders in the intestines in earlyaged children with RVI. Against the background of concomitant food allergy and atopic dermatitis in children with RVI, there are more pronounced laboratory signs of carbohydrate malabsorption, and, as a consequence, diarrhea more pronounced during the height of the disease with a higher incidence of flatulence and intestinal colic.

The research was carried out in accordance with the principles of the Helsinki declaration. The study protocol was approved by the Local Ethics Committee of the participating institution. The informed consent of the patient was obtained for conducting the studies.

No conflict of interest was declared by the author.

Key words: rotavirus infection, early-aged children, carbohydrate malabsorption syndrome, lactase gene polymorphism, food allergy, atopic dermatitis. 


\section{Факторы влияния на выраженность клинико-лабораторных проявлений синдрома мальабсорбции углеводов у детей раннего возраста с ротавирусной инфекцией \\ Н.В. Воробьева \\ Запорожский государственный медицинский университет, Украина}

Цель - определить роль аллельного полиморфизма 13910 С/Т энхансера гена лактазы МСМ6 и наличия сопутствующей пищевой аллергии (ПА) и атопического дерматита (АД) в формировании проявлений синдрома мальабсорбции углеводов у детей раннего возраста с ротавирусной инфекцией (РВИ).

Материалы и методы. Обследовано 60 детей в возрасте 1-24 мес с РВИ. Всем детям при госпитализации проведено определение однонуклеотидного полиморфизма 13910 C/T гена МСМ6 методом полимеразной цепной реакции, общего IgЕ в сыворотке крови методом иммуносерментного анализа при госпитализации, а также общего количества углеводов в кале (проба Бенедикта) и уровня лактозы в кале (проба Мальфатти) в динамике (на III, V, VII, X сутки болезни). Проведена оценка динамических изменений клинико-лабораторных признаков синдрома мальабсорбции углеводов в подгруппах детей с разными вариантами генотипа -13910 С/Т гена MCM6, а также в подгруппах детей в зависимости от наличия сопутствующей аллергической патологии. Результаты. При РВИ у детей-носителей генотипов С/C, С/Т и Т/Т -13910 гена МСM6 не выявлены достоверные различия максимальной суточной частоты диареи, ее продолжительности и частоты регистрации кишечных колик и метеоризма (р>0,05). Не выявлена статистически значимая разница общего уровня углеводов и лактозы в кале на всех этапах болезни (р>0,05 на III, V, VII, X сутки). У детей с сопутствующей ПА и АД отмечалась в 1,3 и 2 раза более высокая суточная частота жидкого стула в период разгара болезни ( $<<0,05$ на V и VII сутки соответственно), в 1,3 раза более длительная диарея ( $<<0,05)$, в 1,6 и 1,8 раза большая частота развития метеоризма и кишечных колик (р<0,05). Дети данной подгруппы имели в 3 и 3,3 раза более высокие показатели пробы Бенедикта $(p<0,01)$, а также в 3 и 2,5 раза более высокие значения пробы Мальфатти ( $<<0,01$; $р<0,05$ соответственно) на III и V сутки РВИ соответственно, чем у пациентов без аллергии, с постепенным уменьшением данной разницы в течение периода реконвалесценции (р>0,05 на Х сутки). Выводы. Вариант аллельного полиморфизма 13910 C/Т гена МСM6 не влияет на степень нарушения метаболизма олигосахаридов в кишечнике детей раннего возраста с РВИ. На фоне сопутствующей ПА и АД у детей с РВИ отмечаются более выраженные лабораторные признаки мальабсорбции углеводов и, как следствие, более выраженная в период разгара болезни диарея с более высокой частотой развития метеоризма и кишечных колик.

Исследование выполнено в соответствии с принципами Хельсинкской декларации. Протокол исследования одобрен Локальным этическим комитетом участвующего учреждения. На проведение исследования получено информированное согласие родителей детей.

Автор заявляет об отсутствии конфоликта интересов.

Ключевые слова: ротавирусная инфекция, дети раннего возраста, синдром мальабсорбции углеводов, полиморфизм гена лактазы, пищевая аллергия атопический дерматит.

\section{Вступ}

$\mathrm{P}$ отавірусна інфекція - основний етіологічний агент гострого гастроентериту в дітей [6,22], що спричиняє від 20\% до 50\% усіх госпіталізацій з приводу гострої діареї в педіатричній практиці [15]. Ротавіруси після пневмококової пневмонії є другою провідною причиною смерті від інфекційних захворювань серед дітей віком до 5 років, що можна попередити за допомогою вакцинації. Більшість дітей вже в перші роки життя переносять декілька епізодів ротавірусної інфекції (PBI). Крім того, саме в дітей перших двох років захворювання перебігає найтяжче та часто потребує госпіталізації через розвиток зневоднення [11].

Патогенез ротавірусної діареї складний та багатокомпонентний. Ротавірус викликає мальабсорбційну діарею як через деструкцію зрілих ентероцитів мікроворсинок тонкої кишки та заміщення їх низько-диференційованими клітинами 3 низьким вмістом ферментів, так і через пригнічення експресії низки генів в ентероцитах, що відповідають за синтез ферментів і білків-переносників [4,9]. Так, J.A. Boshuizen, J.H. Reimerink зі співавт. показали, що на I-VII добу зараження ротавірусом спостерігається апоптоз ентероцитів ворсинок і розростання незрілих епітеліальних клітин. Крім того, дослідники довели, що ротавірус викликає зменшення експресії специфічних для ентероцитів генів (лактази, SGLT1 та L-FABP) в інфікованих клітинах на рівні мРНК i білка, починаючи вже за 6 год після зараження [4]. Зменшення активності SGLT1 на мембранах ентероцитів призводить до порушення симпорту $\mathrm{Na}+-\mathrm{D}$-глюкози, що забезпечує реабсорбцію великих обсягів води у фізіологічних умовах [6]. Відключення специфічної для ентероцитів експресії генів разом із втратою зрілих ентероцитів через апоптоз і заміною цих клітин менш диференційованими призводить до порушення абсорбційної функції кишкового епітелію та дефіциту дисахаридаз (переважно лактази-флоризин-гідролази - LPH) [4,9]. Нерозщеплені вуглеводи, що мають високу осмотичну активність, накопичуються в просвіті тонкої кишки і спричиняють подальшу екстравазацію тканинної рідини в порожнину кишечника, викликаючи осмотичну діарею [12].

Отже, синдром мальабсорбції вуглеводів і вторинна лактазна недостатність (ЛН), зокрема, є важливою складовою патогенезу ротавірусної діареї, особливо в дітей перших років життя, основою раціону яких є багаті на лактозу молоко та молочні продукти. Так, за даними нашого попереднього дослідження, у дітей раннього віку з PBI мальабсорбція вуглеводів асоціюється переважно з вторинною ЛН і виникає в 98,3\% та зберігається до Х доби хвороби в 81,7\% випадків [24]. 
Відомо, що клінічні прояви синдрому мальабсорбції вуглеводів у дітей залежать від сукупної дії багатьох факторів: рівня активності ферменту LPH, кількості лактози, що надходить з їею, індивідуальної чутливості кишечника та стану кишкової мікрофлори [17]. Так, доведено, що підвищення вмісту вуглеводів у фекаліях дітей з PBI як маркера осмотичної діареї є проявом функціональної недостатності сахаролітичних бактерій [16] (чим нижча їх ферментативна активність, тим виразніші зміни лабораторних показників цього синдрому) [23].

Рівень активності ферменту LPH також залежить від дії різних ендогенних факторів, одним 3 яких є рівень експресії гена LCT. Фермент є інтегральним протеїном, що складається 3 двох ензиматичних активностей: $\beta$-D-галактозидгідролази, що гідролізує лактозу до глюкози і галактози, та глікозил-N-ацетил-сфінгозин-глюкогідрази, що забезпечує гідроліз флоризину $[1,8]$. Ген, який відповідає за синтез лактази в організмі, - LCT-ген кодує послідовність 1927 амінокислот у молекулі лактази, складається з 17 екзонів і розташований на довгому плечі 2-ї хромосоми (2q21). Рівень транскрипції гена лактази контролюється розташованим поруч cis-регуляторним елементом MCM6 (minichromosome maintenance complex component 6) [1,14]. Виділяють три варіанти генотипу гена МСM6: генотип C/C-13910 відповідає практично повній відсутності лактази; генотип С/Т-13910 асоціюється зі зниженням рівня лактази, який достатній для нормальної дигестії, проте може мати значення при порушеннях харчування та захворюваннях кишечника; генотип Т/Т-13910 свідчить про високу активність ферменту і виз начає фенотип персистенції лактази LACXP (lactase persistence) [8].

При цьому слід зауважити, що визначення генетичного поліморфізму С/Т-13910 МCM6 гена є доцільним лише для прогнозування розвитку в індивіда в зрілому віці персистенції лактази або первинної ЛН дорослого типу. Проте існує думка, що генотип енхансера гена лактази МСМ6 може посилювати дефіцит лактази, пов'язаний із пошкодженням ентероцитів при інфекційному, алергічному або іншому патологічному процесі в кишечнику, тобто при вторинній ЛН у дітей [1]. Оскільки вторинна ЛН є однією з провідних ланок патогенезу ротавірусного гастроентериту, виникає необхідність поглибленого вивчення впливу генетичного фактора на її виразність протягом хвороби.
До зниження активності ферменту LCT із формуванням вторинної ЛН можуть призводити також ураження ентероцитів на тлі запальних, атрофічних, імунних процесів у кишечнику. Так, наприклад, алергічне запалення слизової оболонки кишечника супроводжується ушкодженням структури ентероцитів і навіть їх руйнуванням [19]. Про формування вторинної ЛН у дітей на тлі харчової алергії повідомляється в ряді досліджень [19,20,21]. Так, діти з ХА та АД у 76\% випадків мають прояви ЛН і кишкового дисбіозу [21].

Отже, алергічне ураження ентероцитів може бути додатковим фактором впливу на тяжкість синдрому мальабсорбції вуглеводів у дітей 3 PBI, що є підставою до поглибленого аналізу цієї проблеми в рамках комплексного вивчення патогенетичних особливостей такого синдрому при ротавірусному гастроентериті.

Mema дослідження - визначити роль алельного поліморфізму $13910 \mathrm{C} / \mathrm{T}$ енхансера гена лактази МСМ6 та наявності супутньої харчової алергії (ХА) й атопічного дерматиту (АД) у формуванні проявів синдрому мальабсорбції вуглеводів у дітей раннього віку з РВI.

\section{Матеріали та методи дослідження}

До дослідження залучено 60 дітей раннього віку на грудному вигодовуванні з доведеним ротавірусним гастроентеритом (63,3\% - хлопчики, 36,7\% - дівчатка), які перебували на стаціонарному лікуванні в дитячому кишковому відділенні КНП «Запорізька обласна інфекційна клінічна лікарня» Запорізької обласної ради. Дітей залучено до відкритого проспективного дослідження відповідно до таких критеріїв: лабораторно підтверджена PBI, госпіталізація протягом перших трьох діб від початку захворювання, перебування на грудному вигодовуванні, відсутність виділення з фекалій патогенної кишкової флори, відсутність вродженої чи хронічної патології шлунково-кишкового тракту, вродженого чи набутого імунодефіциту. Усіх дітей залучено до дослідження за умови інформованої згоди батьків.

Діагноз «Ротавірусна інфекція» встановлено на підставі типової клінічної картини і підтверджено визначенням антигена ротавірусу в калі за допомогою імунохроматографічного методу (із застосуванням тест-систем «CITO TEST ROTA» виробництва «Pharmasco», Україна).

Поряд із загальноприйнятим лабораторним обстеженням, усім дітям основної групи в динаміці PBI, зокрема, на початку хвороби (на 
II-III добу), у період розпалу (на $\mathrm{V}$ та VII добу) та в період реконвалесценції (на X добу) проведено визначення у фекаліях загальної кількості вуглеводів (проба Бенедикта) i рівня лактози (проба Мальфатті). Результат проби Мальфатті оцінено за модифікованою кольоровою шкалою, створеною заздалегідь: «0» - відсутність лактози, «+» 0,2-0,4\% лактози, «++» - 0,5-1,0\% лактози, «+++» - 1,1-1,5\%, «++++»- вище $2 \%$ лактози.

Крім того, усім дітям основної групи в лабораторії мікробіологічних досліджень Навчального медико-лабораторного центру Запорізького державного медичного університету (ЗДМУ) визначено варіант генетичного поліморфізму гена МСМ6 методом полімеразної ланцюгової реакції в режимі реального часу з детекцією кривих плавлення на ампліфікаторі CFX96TM («Bio-Rad Laboratories, Inc.», CША) із застосуванням тест-систем «РеалБест-Генетика МСМ6».

Для аналізу впливу алергічної патології на клініко-лабораторні прояви синдрому мальабсорбції вуглеводів при ротавірусному гастроентериті в дітей проведено порівняльну оцінку даних показників у двох підгрупах дітей, на які поділено основну групу залежно від наявності ХА та АД. До першої підгрупи увійшли 20 дітей з ХА та АД, до другої підгрупи - 40 дітей без алергічної патології та 3 необтяженим сімейним анамнезом щодо алергії. Для виявлення сенсибілізації організму всім дітям визначено рівень загального IgE в сироватці крові за допомогою IФА.

Групу порівняння становили 30 здорових дітей, репрезентативних за віком та статтю, яким одноразово проведено визначення загальної кількості вуглеводів та лактози у фекаліях. Медіани зазначених показників здорових дітей групи порівняння прийнято за фізіологічні для цього віку.

Дослідження виконано відповідно до принципів Гельсінської декларації. Протокол дослідження схвалено локальною етичною комісією ЗДМУ для всіх учасників.
Статистичний аналіз отриманих даних здійснено в програмі «STATISTICA for Windows 13» (StatSoftInc., № JPZ804I382130ARCN10J). Для визначення характеру розподілу даних застосовано критерій Шапіро-Уілка (нульова гіпотеза про нормальність розподілу відхилялася при $\mathrm{p}<0,05)$. Через відхилення розподілу кількісних величин від нормального використано непараметричні методи. Кількісні значення подано у вигляді медіани (Me) та міжквартильного розмаху (IQR: Q25-Q75). Для оцінки достовірності відмінностей між кількісними ознаками в двох незалежних групах застосовано критерій Манна-Уітні, у декількох незалежних групах - критерій КраскеллаУоллеса. Статистичну значущість різниці між групами для порівняння частотних характеристик визначено за допомогою критерію $\chi^{2}$. За наявності в досліджуваних вибірках менше 5 осіб визначено точний критерій Фішера. Різницю показників прийнято статистично значущою при р <0,05.

\section{Результати дослідження та їх обговорення}

Генетичний аналіз показав, що серед хворих на PBI дітей превалює гетерозиготний генотип C/T-13910 енхансера гена лактази МCM6, який відмічався у 60\% $(\mathrm{n}=36)$ пацієнтів, C/C-13910 генотип - у 28,3\% (n=17) випадків, гомозиготний генотип за Т-алеллю (Т/Т-13910) у 11,7\% (n=7) осіб групи дослідження.

Порівняльний аналіз симптомів, пов'язаних iз порушенням метаболізму олігосахаридів у кишечнику (мальабсорбцією вуглеводів) у дітей раннього віку з РВI, що перебували на грудному вигодовуванні, залежно від варіанта алельного поліморфізму гена МСМ6 показав відсутність достовірної різниці показників між підгрупами. Так, діарея спостерігалася в усіх дітей 3 генотипами С/Т-13910 (36 дітей 100\%) i T/Т-13910 (7 дітей - 100\%) і в абсолютної більшості хворих-носіїв C/C-13910 генотипу (16 дітей - 94,1\%). Крім того, з таблиці 1 видно, що статистично не відрізнялися в зазначених підгрупах і показники максималь-

Таблиия 1

Порівняльна характеристика основних клінічних проявів ротавірусної інфекції в дітей залежно від поліморфізму 13910 C/Т гена МСМ6

\begin{tabular}{|c|c|c|c|c|}
\hline \multirow{2}{*}{$\begin{array}{c}\text { Характеристики } \\
\text { діарейного синдрому }\end{array}$} & \multicolumn{3}{|c|}{ Варіант алельного поліморфізму 13910 C>T гена МСM6 } & \multirow{2}{*}{$\begin{array}{c}\mathbf{p} \\
\text { Краскелла-Уоллеса }\end{array}$} \\
\hline & $\mathrm{C} / \mathrm{C}(\mathrm{n}=17)$ & $\mathrm{C} / \mathrm{T}(\mathrm{n}=36)$ & $\mathrm{T} / \mathrm{T}(\mathrm{n}=7)$ & \\
\hline Тривалість діареї, діб & $8,00[5,00 ; 9,00]$ & $8,50[7,00 ; 10,00]$ & $9,00[8,00 ; 10,00]$ & $p=0,3073$ \\
\hline $\begin{array}{l}\text { Максимальна частота } \\
\text { випорожнень за добу, разів }\end{array}$ & $7,00[4,00 ; 11,00]$ & $7,00[5,00 ; 9,50]$ & $9,00[7,00 ; 10,00]$ & $p=0,4454$ \\
\hline
\end{tabular}


Порівняльна оцінка частоти виникнення основних клінічних симптомів мальабсорбції вуглеводів при ротавірусній інфекції в дітей залежно від поліморфізму 13910 C>T гена MCM6

\begin{tabular}{|c|c|c|c|c|c|c|}
\hline \multirow[t]{2}{*}{ Клінічний прояв РВІ } & \multicolumn{3}{|c|}{$\begin{array}{c}\text { Варіант алельного } \\
\text { поліморфізму } 13910 \text { C/T гена МСМ6 }\end{array}$} & \multirow[t]{2}{*}{$\mathbf{P}^{1}$} & \multirow[t]{2}{*}{$\mathbf{P}^{2}$} & \multirow[t]{2}{*}{$\mathbf{P}^{3}$} \\
\hline & $T / T(n=7)$ & $C / T(n=36)$ & $C / C(n=17)$ & & & \\
\hline Діарея & $7(100 \%)$ & $36(100 \%)$ & $16(94,1 \%)$ & $p=0,7083-$ & - & $p=0,3208$ \\
\hline Кишкові кольки & $3(42,9 \%)$ & $10(27,8 \%)$ & $6(35,3 \%)$ & $p=0,9077$ & $p=0,7300$ & $p=0,5780$ \\
\hline Метеоризм & $4(57,1 \%)$ & $23(63,8 \%)$ & $11(64,7 \%)$ & $p=0,9077$ & $p=0,9287$ & $p=0,8034$ \\
\hline
\end{tabular}

Примітки: $\mathrm{P}_{1}-$ різниця показників між групами з генотипом Т/Т та С/С за критерієм $\chi^{2}$; Р 2 - різниця показників між групами 3 генотипом $\mathrm{T} / \mathrm{T}$ та $\mathrm{C} / \mathrm{T}$ за критерієм $\chi^{2}$; Р 3 - різниця показників між групами з генотипом C/T та С/C за критерієм $\chi^{2}$

ної добової частоти рідких випорожнень, що фіксувалися протягом усього періоду гастроентериту (р>0,05 за критерієм Краскелла-Уоллеса), а також тривалості діарейного синдрому ( $>0,05$ за критерієм Краскелла-Уоллеса).

Не впливав генетичний фактор і на частоту реєстрації метеоризму та кишкових кольок у дітей досліджуваної групи (табл. 2). Як у пацієнтів із генотипом C/C-13910, який асоціюється з гіполактазією дорослого типу, так і у хворих з Т/Т-13910 генотипом, який відповідає за персистенцію лактази, клінічний перебіг PBI характеризувався наявністю метеоризму з флатуленцією більш ніж у половині випадків 64,7\% і 57,1\% відповідно (р>0,05 за точним критерієм Фішера). Кишкові кольки відмічалися приблизно в третини хворих кожної з підгруп ( $\mathrm{p}>0,05$ за точним критерієм Фішера).

Результати проведеного аналізу, який не виявив істотної різниці клінічних проявів синдрому мальабсорбції вуглеводів у дітей-носіїв різних генотипів енхансера гена лактази MCM6, можуть свідчити про відсутність вагомої ролі генетичного фактора в патогенезі формування ротавірусної діареї, а також метеоризму та абдомінального больового синдрому саме в дітей раннього віку. Для з'ясування впливу генетичного поліморфізму $13910 \mathrm{C} / \mathrm{T}$ гена МСМ6 на ступінь порушення перетравлювання вуглеводів у тонкому кишечнику прове- дено порівняльну оцінку показників проби Бенедикта та проби Мальфатті у дітей з різними генотипами гена МСM6 у динаміці хвороби.

Проведений аналіз показав, що ні максимальні значення загальної кількості вуглеводів у фекаліях, ні максимальні рівні екскретованої з фекаліями лактози, зареєстровані протягом усього періоду хвороби, статистично не різнилися між групами дітей із різними генотипами енхансера гена лактази МСM6, дорівнюючи $1,50[0,65 ; 1,65] \%$ та $2,00[1,00 ; 3,00]+$ у дітей-носіїв генотипу C/C-13910, 1,25 [0,50; 1,87]\% та $3,00[2,00 ; 4,00]+$ у дітей з генотипом C/T-13910 й $1,12[0,50 ; 2,00] \%$ та $2,00[1,00 ; 3,00]+$ у хворих 3 T/T-13910 генотипом відповідно ( $>>0,05)$.

За результатами оцінки показників проби Бенедикта та проби Мальфатті в динаміці PBI, жоден 3 генотипів енхансера гена лактази MCM6 не асоціювався з більш вираженим підвищенням загального рівня неперетравлених цукрів і лактози, зокрема, у фекаліях (табл. 3) ( $>>0,05$ на III, V, VII та X добу хвороби).

За результатами дослідження, ні генотип C/C-13910 гена МСМ6, що відповідає за гіполактазію конституційного типу, ні гетерозиготний генотип C/T-13910 не асоціювався з більш виразним і тривалим порушенням метаболізму олігосахаридів у кишечнику та, відповідно, не був додатковим фактором впливу на клінічні ознаки синдрому мальабсорбції вуглеводів

Порівняльна оцінка динамічних змін загального рівня вуглеводів і рівня лактози у фекаліях дітей

Таблиия 3 з ротавірусною інфекцією залежно від поліморфізму 13910 C/T гена MCM6, Me [Q25; Q75]

\begin{tabular}{|l|c|c|c|c|c|}
\hline \multicolumn{2}{|c|}{ Показник } & \multicolumn{2}{|c|}{ Варіант алельного поліморфізму 13910 C/T гена МСМ6 } & \multirow{2}{*}{ К Краскелла-Уоллеса } \\
\cline { 2 - 6 } & C/C (n=17) & C/T (n=36) & T/T (n=7) & \\
\hline \multirow{3}{*}{$\begin{array}{l}\text { Проба } \\
\text { Бенедикта, \% }\end{array}$} & III доба & $0,50[0,20 ; 1,00]$ & $1,00[0,40 ; 1,50]$ & $0,40[0,05 ; 1,50]$ & $\mathrm{p}=0,3100$ \\
\cline { 2 - 6 } & V доба & $0,50[0,50 ; 1,50]$ & $0,65[0,50 ; 1,65]$ & $0,50[0,50 ; 2,00]$ & $\mathrm{p}=0,4522$ \\
\cline { 2 - 6 } & VII доба & $0,40[0,20 ; 1,65]$ & $0,87[0,40 ; 1,65]$ & $1,50[0,15 ; 1,65]$ & $\mathrm{p}=0,6037$ \\
\cline { 2 - 6 } & $X$ доба & $0,40[0,20 ; 1,50]$ & $0,50[0,30 ; 1,50]$ & $0,40[0,20 ; 1,50]$ & $\mathrm{p}=0,6023$ \\
\hline \multirow{3}{*}{$\begin{array}{l}\text { Лактоза } \\
\text { фекалій, «+» }\end{array}$} & III доба & $1,00[1,00 ; 2,00]$ & $2,00[1,00 ; 4,00]$ & $1,00[0,00 ; 3,00]$ & $\mathrm{p}=0,4516$ \\
\cline { 2 - 6 } & $V$ доба & $1,00[1,00 ; 2,00]$ & $2,00[1,00 ; 4,00]$ & $2,00[1,00 ; 3,00]$ & $\mathrm{p}=0,070$ \\
\cline { 2 - 6 } & VII доба & $1,00[0,00 ; 3,00]$ & $2,00[1,00 ; 3,50]$ & $2,00[1,00 ; 2,00]$ & $\mathrm{p}=0,5103$ \\
\cline { 2 - 6 } & $X$ доба & $1,00[0,00 ; 3,00]$ & $2,00[1,00 ; 3,00]$ & $1,00[1,00 ; 2,00]$ & $\mathrm{p}=0,5839$ \\
\hline
\end{tabular}


Таблиия 4

Розподіл дітей у підгрупах з/без алергічної патології залежно від рівня загального IgЕ в сироватці крові

\begin{tabular}{|l|c|c|}
\hline \multicolumn{1}{|c|}{ Група } & IgE $>\mathbf{4 6}$ IU/ml & IgE $<\mathbf{4 6 ~ I U / m l ~}$ \\
\hline Діти з АД та ХА ( $\mathrm{n=20})$ & 9 & 11 \\
\hline $\begin{array}{l}\text { Діти без алергічної } \\
\text { патології }(\mathrm{n}=40)\end{array}$ & 0 & 40 \\
\hline
\end{tabular}

у дітей раннього віку з ротавірусним гастроентеритом. Установлені результати відрізняються від даних, отриманих вітчизняними дослідниками. Так, за даними О.С. Абатурова зі співавт., С/С-13910 асоціювався з високою частотою розвитку симптомів мальабсорбції вуглеводів, таких як біль у животі, метеоризм, бурчання в животі, генотип С/Т-13910 з вираженою діареєю, болем у животі, метеоризмом, генотип Т/Т-13910 - з меншою виразністю діарейного синдрому при значній його тривалості, відсутністю больового синдрому та метеоризму [2]. За даними I.I. Незгоди, O.M. Науменко, генотип C/T-13910 асоціювався в дітей з тривалішою ротавірусною діареєю, у дітей з генотипом C/C-13910 відмічався яскраво виражений інтоксикаційний синдром із тривалою фебрильною лихоманкою, натомість діти з генотипом Т/Т-13910 мали найсприятливіший перебіг PBI [18]. Однією з причин таких розбіжностей може виступати ранній вік дітей нашої групи спостереження, медіана якого становила $10,0[6,00 ; 13,50]$ міс, тоді як у наведеному дослідженні [18] середній віко-

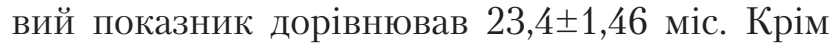
того, саме через віковий аспект доцільність застосування генетичного тесту в діагностиці конституційної ЛН залишається дискутабельною [3,5], оскільки активність ферменту LFH в осіб з фенотипом LNP (lactase non-persistence) знижується лише з віком. За даними літератури, найвища активність лактази спостерігаєть-

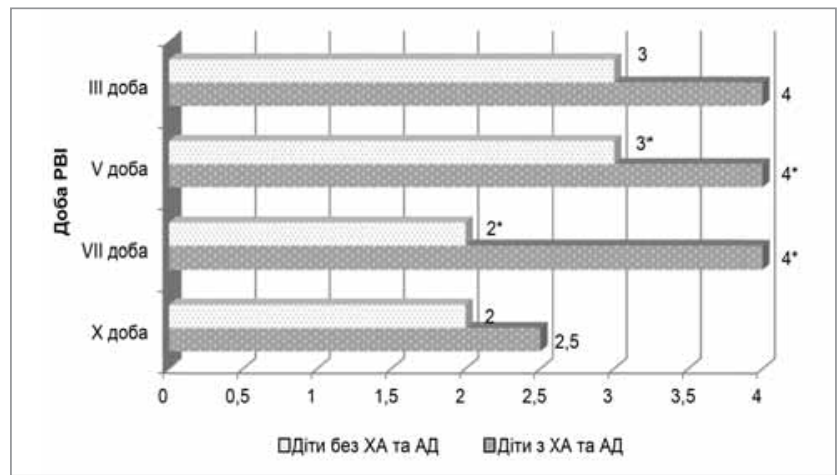

Примітка: * - p<0,05 - достовірна різниця показників у групах за критерієм Манна-Уітні.

Рис. 1. Порівняльна оцінка добової частоти рідких випорожнень у хворих з/без харчової алергії й атопічного дерматиту в динаміці ротавірусного гастроентериту ся при народженні, поступово знижуючись після припинення грудного вигодовування, досягаючи в підлітковому віці лише 5-10\% від активності при народженні в дітей з генотипом C/C-13910 гена MCM6 [13]. Відомо, що на вік початку її зниження впливають етнічне та географічне походження, а також звичайний рівень споживання молочних продуктів населенням [3,7]. Так, за наявності LNP генетично запрограмоване інгібування синтезу лактази проявляється до дворічного віку в більшості тайських дітей, у чорношкірого населення у віці 1-8 років, тоді як в європейських популяціях це рідко зустрічається до 5-річного віку [3]. Тобто ступінь відповідності генотипу 13910 C/T гена MCM6 фенотипу NLP залежить від віку. Так, M.L. Couce, P. SanchezPintos зі співавт. у своєму дослідженні (в якому взяли участь 493 дитини з функціональними порушеннями травлення), показали, що відсоток мальабсорберів лактози серед дітей 3 генотипом C/C-13910 гена MCM6 збільшувався від 8,3\% у віці до 5 років до 62,6\% у дітей від 12 років [5].

Отже, на основі вищезазначених даних щодо вікових особливостей маніфестації LNP у дітей з генотипом C/C-13910 гена MCM6, а також 3 огляду на результати нашого дослідження слід зазначити, що в дітей до дворічного віку при PBI додаткове визначення поліморфізму 13910 C/T гена MCM6 для прогнозування перебігу PBI є недоцільним через відсутність впливу генотипу на виразність вторинної ЛН, оскільки на момент залучення дітей до дослідження в них ще не відбулася маніфестація LNP.

Наступний етап дослідження присвячено вивченню впливу алергічної патології на клініко-лабораторні прояви мальабсорбції вуглеводів у дітей раннього віку з РВI.

У таблиці 4 наведено результати визначення загального IgE в сироватці крові методом імуноферментного аналізу, з яких видно, що 45\% дітей із супутньою алергічною патологією мали підвищений рівень загального IgE, тоді як у жодної дитини з необтяженим алергологічним анамнезом рівень цього показника не перевищував максимально допустимих вікових значень.

Виявлено, що хворі з супутньою ХА та АД мали тяжчу діарею в період розпалу ротавірусного гастроентериту. Так, вже з X доби PBI в дітей цієї підгрупи спостерігалися вищі значення добової частоти рідких випорожнень (рис. 1) (p>0,05) зі збільшенням різниці даних показників на V та VII добу хвороби, коли 
хворі з супутньою алергічною патологією мали в 1,5 та 2 рази вищу добову частоту діареї відповідно, порівняно 3 дітьми 3 необтяженим алергологічним анамнезом $(\mathrm{p}<0,05)$. Слід зазначити, що діарея зберігалася до другого тижня РВI (до X доби) втричі частіше в цієї підгрупи пацієнтів (в 55\% випадків - 11 хворих, проти $17,5 \%-7$ хворих у дітей без алергії; $\chi^{2}=8,78$, $\mathrm{p}=0,003)$. Крім того, тривалість діарейного синдрому в пацієнтів із супутньою ХА та АД була в 1,3 раза більшою, ніж у дітей без зазначеної коморбідної патології, становлячи 10,00 $[9,00 ; 12,00]$ доби проти 7,50 [6,00; 9,00] доби відповідно ( $<<0,05)$.

Діарейний синдром супроводжувався метеоризмом і флатуленцією в абсолютної більшості дітей із супутньою алергією (17-85\%), що відмічалися в 1,6 раза частіше, ніж у дітей другої підгрупи $\left(\chi^{2}=4,75, \mathrm{p}=0,0294\right)$. Крім того, майже половина (9-45\%) хворих з ХА та АД мала нападоподібний абдомінальний біль протягом ротавірусного гастроентериту, що в 1,8 раза перевищувало кількість хворих із кишковими кольками в підгрупі дітей без алергії $\left(\chi^{2}=4,10\right.$, $\mathrm{p}=0,0428)$.

Порівняльний аналіз значень проби Бенедикта, яка відображає загальну здатність до засвоєння олігосахаридів у кишечнику (спроможність ентероцитів тонкої кишки розщеплювати дисахариди та абсорбувати моносахариди), у дітей залежно від наявності супутньої алергічної патології показав, що вже з перших днів хвороби більш виразне порушення зазначених процесів метаболізму вуглеводів у кишечнику спостерігалося в пацієнтів з ХА та АД. Вони мали значне підвищення загального рівня нерозщеплених цукрів у фекаліях з III до V доби PBI (у 10 та 11 разів відповідно вище, ніж у здорових дітей $(\mathrm{p}<0,01))$ із поступовим зниженням значень проби Бенедикта майже втричі на другому тижні хвороби (що, утім, залишався в 4 рази вищим за норму $(\mathrm{p}<0,01))$. Як видно з рис. 2, діти без супутньої алергічної патології мали відносно незначне та стабільне підвищення загального рівня вуглеводів у зразках калу впродовж усього періоду РВI, що був у 3 і 3,3 раза нижчим від значень дітей першої підгрупи на III та V добу PBI відповідно $(\mathrm{p}<0,01)$, з поступовим зменшенням цієї різниці наприкінці першого - початку другого тижня хвороби ( $>0,05)$.

Автори цієї статті спостерігали аналогічну закономірність у різниці рівнів залишкової лактози в копрофільтратах дітей у зазначених

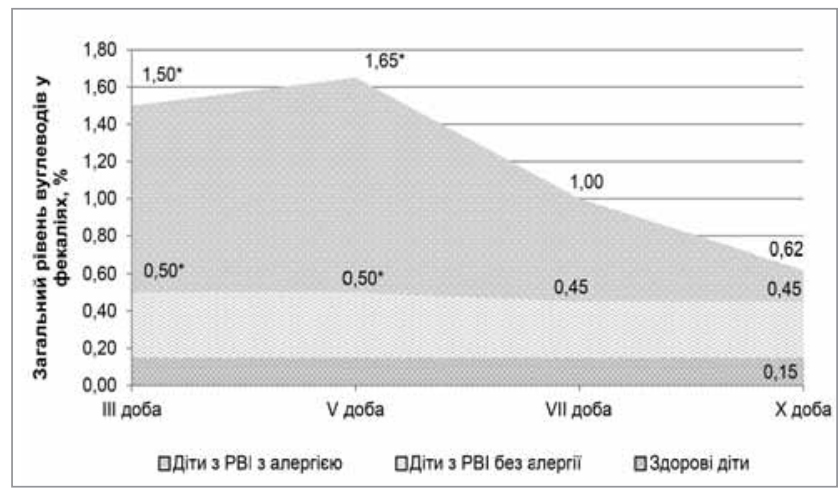

Примітка: * - p<0,05 - достовірна різниця показників у групах за критерієм Манна-Уітні.

Рис. 2. Порівняльна оцінка загального рівня вуглеводів у фекаліях дітей з/без харчової алергії й атопічного дерматиту

підгрупах. Так, пацієнти з ХА та АД на III та $\mathrm{V}$ добу хвороби мали в 3 та в 2,5 раза вищі показники проби Мальфатті, що дорівнювали $3,00[1,50 ; 4,00]+$ та $2,50[1,50 ; 4,00]+$ відповідно $(p<0,01 ; p<0,05$ відповідно), зі збереженням більш виразного порушення розщеплення лактози в кишечнику в зазначеної підгрупи дітей у реконвалесцентному періоді, що виражалося у вдвічі вищому рівні лактози в калі - 2,00 $[1,00 ; 3,50]+$ проти $1,00[1,00 ; 2,00]+$, проте без достовірної різниці показників $(\mathrm{p}>0,05)$.

Отже, результати дослідження показали, що на тлі супутньої ХА та АД у дітей ротавірусний гастроентерит перебігає з більш виразним порушенням перетравлення олігосахаридів у кишечнику переважно за рахунок вторинної ЛН. Патогенетичним підгрунтям цього явища виступає ураження й навіть руйнування ентероцитів тонкої кишки внаслідок алергічного запалення. Відомо, що, незважаючи на поліморфізм клінічних проявів при ХА, шлунковокишковий тракт є тим органом, що уражується в першу чергу [21]. Численні дослідження свідчать про зміни мікробіоти й ознаки імунного запалення слизової оболонки кишечника в таких пацієнтів [20,21]. За даними літератури, основою цього процесу є ушкодження ентероцитів імунними комплексами (антиген-антитіло) та інфільтрація еозинофілами, що індукують запальний процес за участю спеціальних білків - катіонних білків еозинофілів, еозинофільного нейротоксину, пероксидази еозинофілів і так званого major basic protein, які чинять цитотоксичний ефект на епітелій травного тракту, викликають дегрануляцію мастоцитів із подальшим вивільненням цитокінів і нейромедіаторів [19]. Зважаючи на те, що найбільша кількість $\beta$-глікозидазного комплексу (лактази) локалізована на апікальній частині зрілих 
диференційованих ентероцитів, розташованих на верхівці ворсинок, алергічне запалення слизової оболонки кишечника може призводити до значного зменшення ферменту лактази на їх апікальній поверхні [21].

Про розвиток вторинної ЛН на тлі ХА свідчать результати дослідження [21], в якому 62,9\% дітей грудного віку з проявами алергії на продукти харчування мали гастроінтестинальні розлади, такі як метеоризм, зригування, кишкові кольки, нестійкі випорожнення, зниження $\mathrm{pH}$ калу $<5,5$, що розцінювалося як прояви ЛН на тлі ХА та підтверджувалося клінічним поліпшенням перебігу шкірного і гастроінтестинального синдромів у кожної третьої (31,4\%) дитини під впливом замісної ферментативної терапії препаратом лактази поруч з елімінаційною дієтою за 30 діб лікування. За даними S.K. Gupta, S.K.F. Chong, J.F. Fitzgerald зі співавт., ступінь зниження активності лактази при вторинній ЛН тісно корелює зі ступенем атрофії ворсин та інтенсивністю запальних змін слизової оболонки тонкого кишечника [10]. Отже, наявність супутньої алергічної патології у вигляді ХА та АД, будучи додатковим фактором ураження слизової оболонки кишечника, обтяжує прояви синдрому мальабсорбції вуглеводів у дітей 3 ротавірусним гастроентеритом.

\section{Висновки}

За отриманими даними, варіант алельного поліморфізму 13910 гена МСМ6 не впливає на ступінь порушення метаболізму олігосахаридів у кишечнику дітей раннього віку з РВI, про що свідчить відсутність різниці як клінічних проявів синдрому мальабсорбції вуглеводів, так i лабораторних маркерів цього синдрому, зокрема, загальної кількості вуглеводів і рівня лактози в калі пацієнтів із генотипами $\mathrm{C} / \mathrm{C}$, C/T i T/T-13910 гена MCM6 у динаміці захворювання ( $\mathrm{p}>0,05$ на III, V, VII та X добу хвороби).

Наявність супутньої алергічної патології в дітей раннього віку з PBI є тригерним фактором щодо ознак мальабсорбції вуглеводів, що виражається в 1,3 та 2 рази більшій добовій частоті рідких випорожнень у період розпалу хвороби (на V та VII добу відповідно) $(\mathrm{p}<0,05)$, тривалішій в 1,3 раза діареї $(\mathrm{p}<0,05)$, що зберігається до X доби PBI втричі частіше, ніж у дітей без алергії, а також в 1,6 та 1,8 раза вищою частотою реєстрації метеоризму та кишкових кольок відповідно $(\mathrm{p}<0,05)$.

Наявність супутньої алергічної патології $€$ фактором більш виразного і тривалого порушення розщеплення та всмоктування олігосахаридів у кишечнику при PBI, про що свідчать у 3 та 3,3 раза вищі показники проби Бенедикта $(\mathrm{p}<0,01)$, а також у 3 та 2,5 раза вищі значення проби Мальфатті $(\mathrm{p}<0,01 ; \mathrm{p}<0,05$ відповідно) на III та V добу PBI відповідно, ніж у пацієнтів із необтяженим алергологічним анамнезом, із поступовим зменшенням цієї різниці протягом періоду реконвалесценції ( $>>0,05$ на Х добу).

Подяка. Автор висловлює подяку за безпосередню участь у проведенні дослідження та сприяння в підготовці статті науковому керівнику - зав. кафедри дитячих інфекційних хвороб ЗДМУ, д.мед.н., професору Усачовій О.В., начальнику навчального медиколабораторного центру ЗДМУ, д.мед.н., професору Абрамову А.В., зав. кафедри мікробіології, вірусології та імунології ЗДМУ, к.мед.н., доценту Поліщук Н.М.

Автор заявляе про відсутність конфлікту iнтересів.

\section{REFERENCES/JITEPATУPA}

1. Abaturov AE, Nikulina AA, Petrenko LL. (2015). Lactase deficiency in children. International Journal of Pediatrics, Obstetrics and Gynecology. 7 (2): 51-63. [Абатуров АЕ, Никулина АА, Петренко ЛЛ. (2015). Лактазная недостаточность у детей. Международный журнал педиатрии, акушерства и гинекологии. 7 (2): 51-63]. URL: http://repo.dma.dp.ua/id/eprint/1397.

2. Abaturov AE, Stepanova YY, Gerasymenko ON. (2014). Peculiarities of rotavirus infection in children with different genotypes of the lactase gene. Medical perspectives. 19 (4): 146-153. [Абатуров ОЄ, Степанова ЮЮ, Герасименко ОМ. (2014). Особливості перебігу ротавірусної інфекції у дітей з різними генотипами гена лактази. Медичні перспективи. 19 (4): 146-153]. URL: http://nbuv.gov.ua/UJRN/Mp_2014_19_4_25.

3. Almon R, Sjostrom, M, Nilsson TK. (2013). Lactase non-persistence as a determinant of milk avoidance and calcium intake in children and adolescents. Journal of nutritional science. 2: e26. URL: https://doi.org/10.1017/jns.2013.11.

4. Boshuizen JA, Reimerink JH, Korteland-van Male AM, van Ham VJ, Koopmans MP, Buller HA, Dekker J, Einerhand AW. (2003). Changes in small intestinal homeostasis, morphology, and gene expression during rotavirus infection of infant mice. Journal of virology. 77 (24): 13005-13016. URL: https://doi.org/10.1128/jvi.77.24.1300513016.2003.

5. Couce ML, Sanchez-Pintos P, Gonzalez-Vioque E, Leis R. (2020). Clinical Utility of LCT Genotyping in Children with Suspected Functional Gastrointestinal Disorder. Nutrients. 12 (10): 3017. URL: https://doi.org/10.3390/nu12103017.

6. Crawford SE, Ramani S, Tate JE, Parashar UD, Svensson L, Hagbom M, Franco MA, Greenberg HB, O'Ryan M, Kang G, Desselberger U, Estes MK. (2017). Rotavirus infection. Nature reviews. Disease primers. 3: 17083. URL: https://doi.org/10.1038/nrdp.2017.83.

7. Fassio F, Facioni MS, Guagnini F. (2018). Lactose Maldigestion, Malabsorption, and Intolerance: A Comprehensive Review with a Focus on 
Current Management and Future Perspectives. Nutrients. 10 (11): 1599 URL: https://doi.org/10.3390/nu10111599.

8. Forsgard RA. (2019). Lactose digestion in humans: intestinal lactase appears to be constitutive whereas the colonic microbiome is adaptable. The American journal of clinical nutrition. 110 (2): 273-279. URL: https://doi.org/10.1093/ajcn/nqz104.

9. Greenberg HB, Estes MK. (2009). Rotaviruses: from pathogenesis to vaccination. Gastroenterology. 136 (6): 1939-1951. URL: https://doi.org/10.1053/j.gastro.2009.02.076.

10. Gupta SK, Chong SK, Fitzgerald JF. (1999). Disaccharidase activities in children: normal values and comparison based on symptoms and histologic changes. Journal of pediatric gastroenterology and nutrition. 28 (3): 246-251. URL: https://doi.org/10.1097/00005176-199903000-00007.

11. Guzel M, Akpinar O, Kilic MB. (2020). Prevalence of Rotavirus-Associated Acute Gastroenteritis Cases in Early Childhood in Turkey: MetaAnalysis. Children (Basel, Switzerland). 7 (10): 159. URL: https://doi.org/10.3390/children7100159.

12. Ivanko OH, Bondarenko VM. (2021). Cluster analysis of the acute diarrhea causes in young children admitted to the infectious diseases unit. Pathologia. 18 (2): 196-202. [Іванько ОГ, Бондаренко ВМ. (2021). Кластерний аналіз причин гострих діарей у дітей раннього віку, госпіталізованих в інфекційне відділення. Патологія. 18 (2): 196-202]. URL: https://doi.org/10.14739/2310-1237.2021.2.229500.

13. Jasielska M, Grzybowska-Chlebowczyk U. (2019). Lactose Malabsorption and Lactose Intolerance in Children with Inflammatory Bowe Diseases. Gastroenterology research and practice. (4): 1-6. URL: https://doi.org/10.1155/2019/2507242.

14. Juhl CR, Bergholdt H, Miller IM, Jemec G, Kanters JK, Ellervik C. (2018). Lactase Persistence, Milk Intake, and Adult Acne: A Mendelian Randomization Study of 20,416 Danish Adults. Nutrients. 10 (8): 1041. URL: https://doi.org/10.3390/nu10081041.

15. Kung YH, Chi H, Liu CC, Huang YC, Huang YC, Wu FT, Huang LM, Taiwan Pediatric Infectious Disease Alliance. (2020). Hospital-based surveillance of severe rotavirus gastroenteritis and rotavirus strains in young Taiwanese children. Journal of the Formosan Medical Association = Taiwan yi zhi. 119 (7): 1158-1166. URL: https://doi.org/10.1016/j.jfma.2020.03.019.

16. Meskina ER. (2015). Carbohydrate malabsorption syndrome in children with viral gastroenteritis. Almanac of Clinical Medicine. 42: 79-86. [Mecкина ЕР. (2015). Синдром мальабсорбции углеводов у детей с вирусным гастроэнтеритом. Альманах клинической медицины. 42: 79-86]. URL: https://doi.org/10.18786/2072-0505-2015-42-79-86.
17. Misselwitz B, Butter M, Verbeke K, Fox MR. (2019). Update on lactose malabsorption and intolerance: pathogenesis, diagnosis and clinical management. Gut. 68 (11): 2080-2091. URL: https://doi.org/10.1136/gutjnl-2019-318404.

18. Nezgoda I, Naumenko O. (2016). Rotavirus infection in children with different variants of allelic polymorphism C>T 13910 gene LCT. Journal of Education, Health and Sport. 6 (7): 566-578. URL: http://doi.org/10.5281/zenodo.59126.

19. Shadrin OG, Haiduchyk HA. (2019). Lactose intolerance in allergic enterocolitis in infants. Zdorov'e rebenka. 14 (2): 61-66. [Шадрін ОГ, Гайдучик ГА. (2019). Інтолерантність до лактози при алергічному ентероколіті у дітей грудного віку. Здоров'я дитини. 14 (2): 61-66]. URL: https://doi.org/:10.22141/2224-0551.14.2.2019.165540.

20. Shadrin OG, Koval'chuk AA, Dyukareva SV, Fy'sun VM. (2019). Kompleksne likuvannya atopichnogo dermaty'tu $v$ ditej grudnogo viku iz suputn'oyu laktaznoyu nedostatnisty. Zdorov'e rebënka. 14 (5): 19-26. [Шадрін ОГ, Ковальчук АА, Дюкарева СВ, Фисун ВМ. (2019). Комплексне лікування атопічного дерматиту в дітей грудного віку із супутньою лактазною недостатністю. Здровье ребенка. 14 (5): 19-26]. URL: http://www.mif-ua.com/archive/article/48145.

21. Stroy OA, Slipachuk LV, Antoshkina AN, Kazakova LN. (2017). Correction of lactose deficiency in infants with symptoms of allergy to foods. Current issues of pediatrics, obstetrics and gynecology. 2: 15-20. [Строй ОА, Сліпачук ЛВ, Антошкіна АМ, Казакова ЛМ. (2017). Корекція лактазної недостатності у дітей грудного віку з проявами алергії на харчові продукти. Актуальні питання педіатрії, акушерства та гінекології. 2: 15-20]. URL: https://doi.org/10.11603/24116-4944.2017.2.7796.

22. Troeger C, Khali IA, Rao PC, Cao S, Blacker BF, Ahmed T, Armah G, Bines JE, Brewer TG, Colombara DV, Kang G, Kirkpatrick BD, Kirkwood CD, Mwenda JM, Parashar UD, PetriWA, Jr Riddle MS, Steele AD, Thompson RL, Walson JL, Reiner RC Jr. (2018). Rotavirus Vaccination and the Global Burden of Rotavirus Diarrhea Among Children Younger Than 5 Years. JAMA pediatrics. 172 (10): 958-965. URL: https://doi.org/10.1001/jamapediatrics.2018.1960.

23. Vorobiova NV, Usachova OV, Kaplaushenko AH. (2021). Pathogenetic role of intestinal microflora in carbohydrate malabsorption syndrome in earlyaged children with rotavirus infection. Zaporozhye medical journal. 23 (5): 683-690. URL: https://doi.org/10.14739/2310-1210.2021.5.231265.

24. Vorobiova NV, Usachova OV. (2021). Laboratory signs of carbohydrate malabsorption in early age children with rotavirus infection. Pathologia. 18 (1): 72-79. [Воробйова НВ, Усачова ОВ. (2021). Лабораторні ознаки мальабсорбції вуглеводів у дітей раннього віку з ротавірусною інфекцією. Патологія. 18 (1): 72-79]. URL: https://doi.org/10.14739/2310-1237.2021.1.228925.

\section{Відомості про авторів:}

оробйова Наталія Володимирівна - к.мел.н. аспірант каф. дитячих інфекцийних хвороб Запорізького ДМу Алреса: м. Запоріжжя, бул. Гвардійський, 142; тел. + +38 (093) 539-47-43. https://orcid.org/0000-0001-7610-8067.

Стаття надійшла до редакції 29.07.2021р., прийнята до друку 09.11.2021 р. 


\title{
А.Г. Гасанов, И.Е. Гусейнова \\ Показатели витамина D при коронавирусной инфекции COVID-19 у детей
}

\author{
Азербайджанский медицинский университет, г. Баку
}

Modern Pediatrics. Ukraine. (2021). 7(119): 34-39. doi 10.15574/SP.2021.119.34

For citation: Hasanov AG, Huseinova IE. (2021). Indicators of vitamin D in case of Coronavirus infection COVID-19 in children. Modern Pediatrics. Ukraine. 7(119): 34-39. doi 10.15574/SP.2021.119.34.

Цель - определить и сравнить показатели витамина D у детей с COVID-19-ассоциированной пневмонией и здоровых детей.

Материалы и методы. В исследовании приняли участие 90 детей. Основную группу составили 75 детей, находившихся на стационарном лечении c COVID-19-ассоциированной пневмонией (ПЦР-тест положительный). Пациентов основной группы разделили на две подгруппы: I - 49 пациентов с пневмонией среднетяжелого течения, a II - 26 пациентов с пневмонией тяжелого течения. Контрольную группу составили 15 практически здоровых детей. Схема обследования больных детей включала анамнестические данные, использование клинических, инструментальных, лабораторных, иммунологических методов обследования. Концентрацию витамина D в сыворотке крови больных и здоровых детей определяли методом иммунофрерментного анализа. Показатели измеряли на приборе «Stat Fax 4700» с использованием реактивного набора «Pishqaman» (производства Германии).

Результаты. Концентрация витамина D в сыворотке крови была ниже в 1,8 раза в I подгруппе и в 2,0 раза во II подгруппе по сравнению с контрольной группой. Средние значения витамина D в сыворотке крови были ниже по сравнению с контрольной группой в 1,1 раза в возрастной группе детей до 1 года, в 1,1 раза - 1-3 лет, в 2,3 раза - старше 3 лет.

Выводы. На основании наших исследований можно сделать вывод о наличии взаимосвязи между дефицитом витамина D и COVID-19. Taк, средний уровень витамина D был ниже у детей с COVID-19-ассоциированной пневмонией, причем варьировал в зависимости от тяжести заболевания (более выраженные изменения наблюдались при тяжелом течении пневмонии). Также имеют место различия уровней витамина $\mathrm{D}$ в возрастных группах детей c COVID-19-ассоциированной пневмонией: у детей раннего возраста (младше 1 года и 1-3 года) снижение уровня витамина D в сыворотке крови выражено меньше, чем в возрастной группе старше 3 лет. Основные механизмы участия витамина D в процессе иммуномодуляции при COVID-19 требуют дальнейшего изучения.

Исследование выполнено в соответствии с принципами Хельсинкской декларации. Протокол исследования одобрен Локальным этическим комитетом участвующего учреждения. На проведение исследований получено инсормированное согласие родителей детей.

Авторы заявляют об отсутствии конфлликта интересов.

Ключевые слова: дети, COVID-19, витамин D.

\section{Indicators of vitamin D in case of Coronavirus infection COVID-19 in children A.G. Hasanov, I.E. Huseinova \\ Azerbaijan Medical University, Baku}

Purpose - to determine and compare vitamin D levels in children diagnosed with COVID-19-associated pneumonia and healthy children.

Materials and methods. The study involved 90 children. The main group consisted of 75 inpatient children with a diagnosis of COVID-19-associated pneumonia (positive PCR - polymerase chain reaction with reverse transcription). Patients in the main group were divided into 2 subgroups: subgroup I consisted of 49 patients with a pneumonia of moderate course, and subgroup II -26 patients with a pneumonia of severe course. The control group consisted of 15 practically healthy children. The scheme of examination of sick children included anamnestic data, the use of clinical, instrumental and laboratory, immunological examination methods. The concentration of vitamin $\mathrm{D}$ in the blood serum of sick and healthy children was determined by the method of enzyme-linked immunosorbent assay (ELISA). The indicators were measured on a Stat Fax 4700 device using a Pishqaman reactive kit (made in Germany).

Results. The concentration of vitamin D in blood serum was 1.8 times lower in subgroup I and 2.0 times in subgroup II, compared with the control group. The average values of vitamin $D$ in blood serum compared with the control group were $<1.1$ times lower in the age group $<1$ year, 1.1 times lower in the age group 1-3 years, and 2.3 times lower in the age group $>3$ years.

Conclusions. Based on our research, it can be concluded that there is a relationship between vitamin D deficiency and COVID-19. Thus, the average level of vitamin D was lower in children with COVID-19-associated pneumonia, and varied depending on the severity of the disease (more pronounced changes were observed in severe pneumonia). There are also differences in vitamin D levels in the age groups of children with COVID-19-associated pneumonia: in children from age groups under 1 year and 1-3 years old the decrease in serum vitamin D level is less pronounced than in the age group over 3 years old. The main mechanisms of vitamin $D$ involvement in the immune modulation process in COVID-19 require further study.

The research was carried out in accordance with the principles of the Helsinki declaration. The study protocol was approved by the Local ethics committee of the participating institution. The informed consent of the patient was obtained for conducting the studies.

No conflict of interest was declared by the authors.

Key words: children, COVID-19, vitamin D.

\section{Показники вітаміну D при коронавірусній інфекції COVID-19 у дітей \\ А.Г. Гасанов, І.Є. Гусейнова \\ Азербайджанський медичний університет, м. Баку}

Мета — визначити і порівняти показники вітаміну D в дітей з COVID-19-асоційованою пневмонією і здорових дітей.

Матеріали та методи. У дослідженні взяли участь 90 дітей. Основну групу становили 75 дітей, які перебували на стаціонарному лікуванні з COVID-19-асоційованою пневмонію (ПЛР-тест позитивний). Пацієнтів основної групи поділили на дві підгрупи: I - 49 пацієнтів із пневмонією середньотяжкого перебігу; II — 26 пацієнтів із пневмонією тяжкого перебігу. Контрольну групу становили 15 практично здорових дітей. 
Схема обстеження хворих дітей включала анамнестичні дані, застосування клінічних, інструментальних і лабораторних, імунологічних методів обстеження. Концентрацію вітаміну D у сироватці крові хворих і здорових дітей визначали методом імуноферментного аналізу. Показники вимірювали на приладі «Stat Fax 4700» із використанням реактивного набору «Pishqaman» (виробництва Німеччини).

Результати. Концентрація вітаміну D у сироватці крові була нижча в 1,8 раза в I підгрупі та в 2,0 раза в II підгрупі порівняно з контрольною групою. Середні значення вітаміну D у сироватці крові дітей були нижні порівняно з контрольною групою в 1,1 раза у віковій групі до 1 року, в 1,1 раза - 1-3 років, у 2,3 раза - від 3 років.

Висновки. На підставі досліджень можна зробити висновок про наявність взаємозв'язку між рівнем вітаміну D i COVID-19. Так, середній рівень вітаміну D був нижчим у дітей із COVID-19-асоційованою пневмонією, причому варіював залежно від тяжкості захворювання (більш виразні зміни спостерігалися при тяжкому перебігу пневмонії). Також спостерігається розбіжність рівнів вітаміну D у вікових групах дітей із COVID-19-асоційованою пневмонією: у дітей раннього віку (до 1 року та 1-3 роки) зниження рівня вітаміну D у сироватці крові виражено менше, ніж у віковій групі від 3 років. Основні механізми участі вітаміну D у процесі імуномодуляції за COVID-19 потребують подальшого вивчення.

Дослідження виконано відповідно до принципів Гельсінської декларації. Протокол дослідження ухвалено Локальним етичним комітетом усіх зазначеної в роботі установи. На проведення досліджень отримано інформовану згоду батьків дітей.

Автори заявляють про відсутність конфолікту інтересів.

Ключові слова: діти, COVID-19, вітамін D.

$\prod_{c}^{a}$ андемия COVID-19 продолжает распространяться по миру, оказывая негативное влияние на здоровье человека. Новая коронавирусная инфекция SARS-CoV-2 это острое респираторное заболевание с высокой контагиозностью, характеризующееся повреждением дыхательных путей, воспалением и интоксикацией $[20,27]$.

Коронавирус, обнаруженный впервые в конце декабря 2019 года и начале 2020 года в городе Ухане, провинция Хубэй в Китае, может вызывать респираторные заболевания у людей - от легкой формы острой респираторной инфекции до тяжелого острого респираторного синдрома (SARS - Severe acute respiratory syndrome) $[10,12]$.

Научные исследования показывают, что дети всех возрастов, как и взрослые, подвержены риску заражения коронавирусом и даже играют важную роль в передаче вируса $[2,18]$. Исследователи многих стран отмечают, что у детей болезнь протекает бессимптомно или более легко, чем у взрослых [22,33].

Из многочисленных недавних исследований, описанных в литературе, получены данные о наличии связи между витамином D и коронавирусной инфекцией COVID-19 [16].

На основе статистического анализа клинических данных, полученных Darren (2021) et al., Akoglu (2021), Erkan Tursun (2021) [1,7,14] и другими, определено, что уровень витамина D y пациентов c COVID-19 низкий. Исследователи из Северо-Западного университета в США обнаружили корреляцию между уровнем витамина D и цитокиновым штормом гипервоспалительным состоянием, вызванным чрезмерно активной иммунной системой [5]. Они считают, что витамин $\mathrm{D}$ не только укрепляет врожденную иммунную систему, но и предотвращает ее чрезмерную активность, защищая пациентов от осложнений COVID-19. Эта гипотеза также объясняет, почему дети менее восприимчивы к COVID-19. Таким образом, приобретенная иммунная система у детей, склонная к экстремальным реакциям, еще не полностью развита $[3,4,11,26]$.

Известно, что витамин D за счет активации клеток иммунной системы усиливает их аутокринный, паракринный эффект. Он выполняет важную роль во многих химических и биологических процессах в организме. Это связано с взаимодействием витамина $\mathrm{D}$ с клетками иммунной системы в различных процессах [32].

Витамин D, играя важную роль в поддержании гомеостаза, участвует в формировании и развитии патологических состояний, связанных с иммунной системой, таких как острые и хронические воспалительные процессы и аутоиммунные заболевания [24]. При воспалительных процессах витамин D снижает выработку многих воспалительных цитокинов (интерлейкина 6 , фактора некроза опухоли $\alpha$, хемокинов CXCL8, CXCL10) и других биологически активных веществ, предотвращает повреждение клеток, а также, способствуя взаимодействию между макрофагами и лимфоцитами, стимулирует функцию Т-лимфоцитов [6,25,29,34].

Также известно, что витамин D увеличивает секрецию двух антимикробных пептидов, называемых кателицидином и $\beta$-дефенсином,

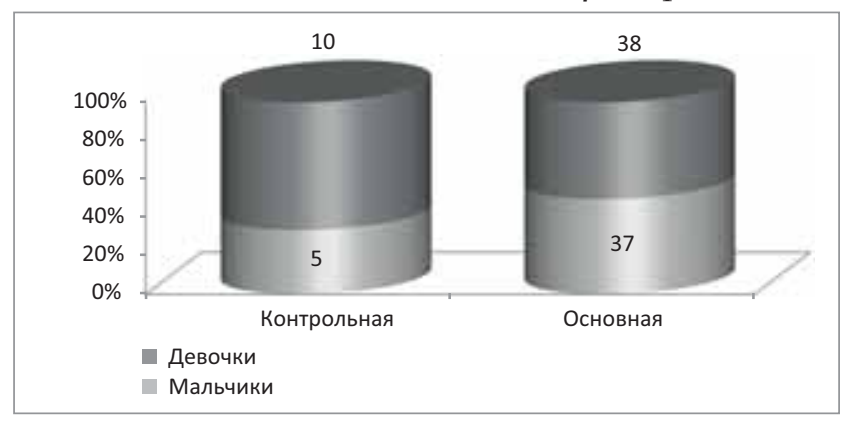

Pис. 1. Половая характеристика детей исследуемых групп 
Таблица 1

Распределение детей по возрасту

\begin{tabular}{|c|c|c|c|c|c|c|c|c|}
\hline \multirow{2}{*}{ Возраст } & \multicolumn{2}{|c|}{ Основная группа } & \multicolumn{2}{|c|}{ Контрольная группа } & \multicolumn{2}{|c|}{ Всего } & $\mathbf{P} \chi^{2}$ & $\mathrm{pU}$ \\
\hline & абс. & $\%$ & абс. & $\%$ & абс. & $\%$ & & \\
\hline Младше 1 года & 22 & 29,3 & 3 & 20,0 & 25 & 27,8 & & \\
\hline 1-3 года & 10 & 13,3 & 1 & 6,7 & 11 & 12,2 & 0,502 & 0,286 \\
\hline Старше 3 лет & 43 & 57,3 & 11 & 73,3 & 54 & 60,0 & & \\
\hline
\end{tabular}

которые играют ключевую роль во врожденном иммунитете. Эти пептиды оказывают цитотоксическое действие, непосредственно влияя на клеточные мембраны микробов, вирусов, бактерий и других патогенов, а также плейотропное действие на индукцию иммуномодулирующих реакций на патогенные раздражители [21,23,30].

Цель исследования - определить и сравнить показатели витамина D у детей с COVID-19-acсоциированной пневмонией и здоровых детей.

\section{Материалы и методы исследования}

Исследование проведено в 2021 г. на базе Детской инфекционной больнице № 7 г. Баку (в период пандемии COVID-19 является клиникой, находящейся в списке учреждений здравоохранения Азербайджанской Республики, предназначенных для лечения детей c COVID-19-ассоциированной патологией).

В исследовании приняли участие 90 детей. В основную группу вошли 75 детей, находившихся на стационарном лечении с подтвержденным положительной полимеразной цепной реакцией с обратной транскрипцией (ПЦР) COVID-19. Пациентов основной группы разделили на две подгруппы: I подгруппу составили 49 пациентов с COVID-19-ассоциированной пневмонией среднетяжелого течения, а II подгруппу - 26 пациентов с COVID-19-ассоциированной пневмонией тяжелого течения.

В исследование не включили бессимптомных пациентов (без клинических или радиоло-

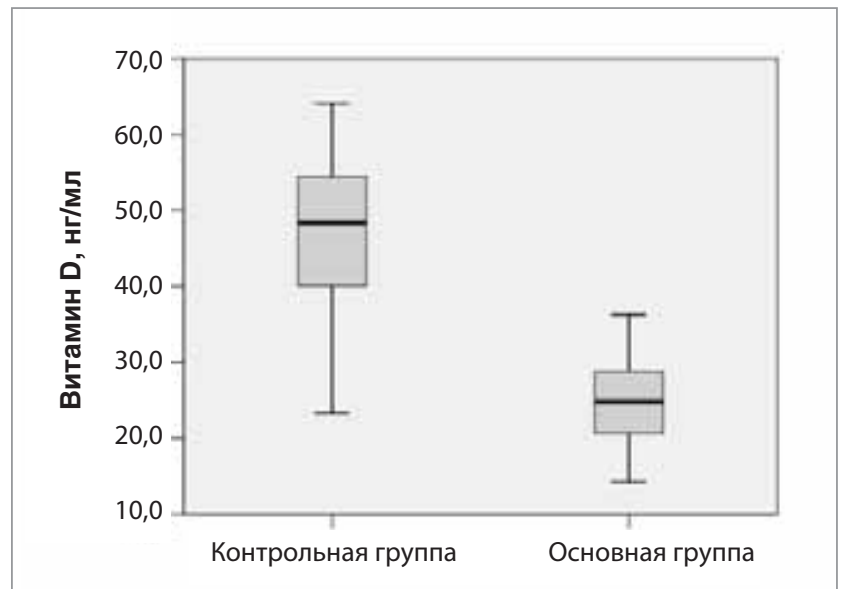

Pис. 2. Сравнительные концентрации витамина D y детей исследуемых групп гических признаков заболевания) с положительным результатом ПЦР на COVID-19.

Контрольную группу составили 15 практически здоровых детей.

В основной и контрольной группах провели сравнение показателей витамина D.

В основную группу вошли 37 (49,3\%) мальчиков и 38 (50,7\%) девочек, в контрольную 5 (33,3\%) мальчиков и 10 (66,7\%) девочек; $\mathrm{pU}=0,170$ (рис. 1).

Схема обследования больных детей включала анамнестические данные, использование клинических, инструментальных, лабораторных, иммунологических методов обследования. Для изучения уровня витамина D во время острой фазы заболевания взяты образцы сыворотки крови пациентов.

Концентрация витамина D в сыворотке крови больных и здоровых детей определена методом иммуноферментного анализа. Показатели измеряны на приборе «Stat Fax 4700» с использованием реактивного набора «Pishqаman» (производства Германии).

Уровни 25-ОН витамина D в крови оценены следующим образом: $\geq 30$ нг/мл - нормальный уровень, 21-29 нг/мл (52,5 и 72,5 нмоль/л) низкий уровень, $\leq 20$ нг/мл (<50 нмоль/л) недостаточность [19].

Исследование выполнено в соответствии c принципами Хельсинкской декларации. Протокол исследования одобрен Локальным этическим комитетом участвующего учреждения. На проведение исследований получено информированное согласие родителей детей.

Полученные цифровые данные обработаны статистически при помощи пакета «SPSS-26» с использованием критериев вариации (U Манна-Уитни: Краскела-Уоллиса), дискриминации $\left(\chi^{2}-\right.$ Пирсон) и дисперсии (F Фишер). Различия между группами признаны статистически значимыми при р<0,05.

\section{Результаты исследования и их обсуждение}

Сравнительные результаты клинических симптомов заболевания среди групп были следующими. У больных, обратившихся в клинику, в острую фазу наблюдались высокая темпе- 


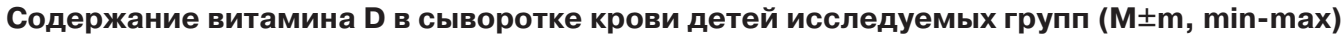

\begin{tabular}{|l|c|c|c|}
\hline \multirow{2}{*}{} & \multicolumn{2}{|c|}{ Основная группа } & \multirow{2}{*}{ Контрольная группа (n=15) } \\
\cline { 2 - 3 } & I подгруппа (n=49) & II подгруппа (n=26) & $46,4 \pm 3,0(23,3-64,2)$ \\
\hline Витамин D, нг/мЛ & $25,9 \pm 0,7(17,3-36,3)$ & $23,5 \pm 1,2(14,2-36,1)$ & \\
\hline p & $<0,001$ & $<0,001$ & \\
\hline p1 & & 0,050 & \\
\hline
\end{tabular}

Примечание. Статистическая достоверность различия показателей в группах по критерию Манна-Уитни: р - статистическая достоверность различия по сравнению с показателями контрольной группы, р1 - статистическая достоверность различия по сравнению с показателями І подгруппы.

ратура и симптомы интоксикации средней тяжести, катаральные симптомы - кашель, ринорея, потеря вкусовых ощущений и обоняния, боль в мышцах, головная боль, повышенный уровень С-реактивного белка, скорости оседания эритроцитов, показатель фибриногена, d-димера, ферритина и др.

В результате исследования обнаружено, что уровни витамина D в сыворотке крови пациентов основной группы были относительно ниже, чем в контрольной группе (рис. 2).

Обнаружено, что уровень витамина D между группами варьировал в зависимости от тяжести заболевания (I и II подгруппы). Концентрации витамина D в сыворотке крови пациентов основной и контрольной групп представлены в таблице 2 .

Как видно из таблицы 2, уровень витамина D в сыворотке крови больных I подгруппы составил 25,9 $\pm 0,7$ нг/мл $(\mathrm{p}<0,001)$, II подгруппы $-23,5 \pm 1,2$ нг/мл $(\mathrm{p}<0,001)$, что отличается от показателей контрольной группы 46,4 $\pm 3,0$ нг/мл (23,3-64,2).

Концентрация витамина D в сыворотке крови пациентов I подгруппы по сравнению с соответствующим показателем в контрольной группе была ниже в 1,8 раза ( $<<0,001)$, а II подгруппы - в 2,0 раза $(\mathrm{p}<0,001)$.

Средние значения витамина D в сыворотке крови также отличались между подгруппами. Количественные изменения уровня витамина D между подгруппами были следующие: во II подгруппе показатель снизился в 1,1 раза по сравнению с I подгруппой (р1=0,05).

Уровни витамина D также отличались в возрастных группах детей с COVID-19-ассоциированной пневмонией.

Уровень витамина D в сыворотке крови детей с COVID-19-ассоциированной пневмонией был ниже в разных возрастных группах по сравнению с показателями в контрольной группе (рис. 3-5). Так, в возрастной группе детей до 1 года он составлял соответственно $27,8 \pm 1,3$ нг/мл и $31,4 \pm 5,1$ нг/мл $(\mathrm{p}=0,663)$, в возрастной группе 1-3 года $-29,0 \pm 1,3$ нг/мл

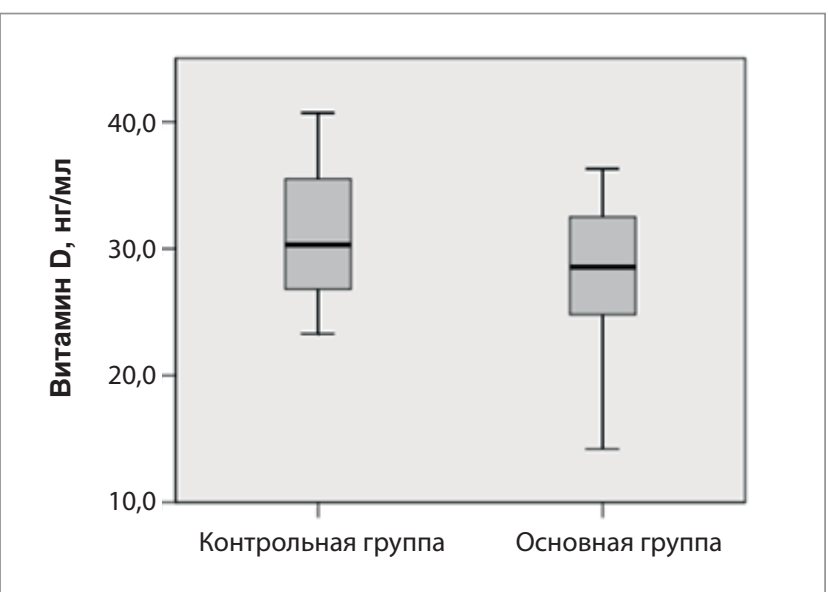

Pис. 3. Сравнительные концентрации витамина D у больных и здоровых детей младше 1 года

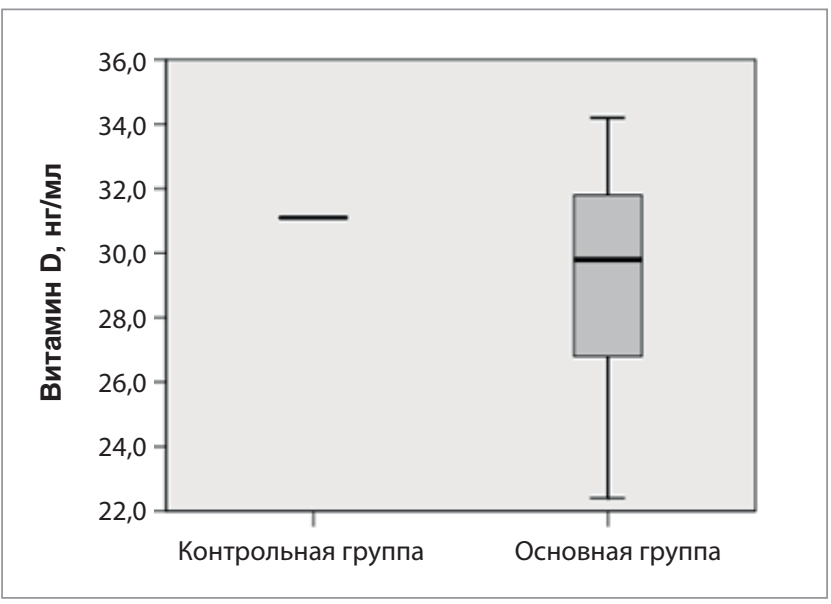

Pис. 4. Сравнительные концентрации витамина D у больных и здоровых детей в возрасте 1-3 лет

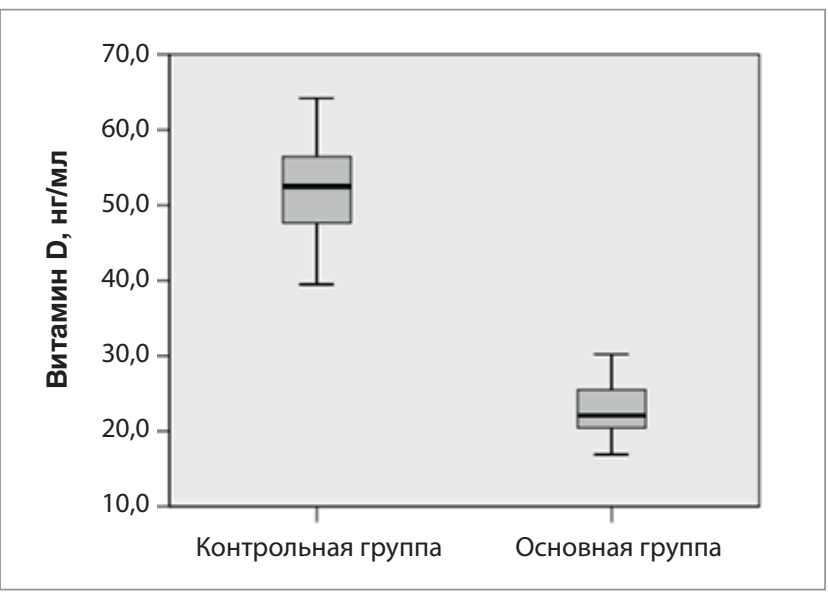

Pис. 5. Сравнительные концентрации витамина D у больных и здоровых детей старше 3 лет 
и 31,1 нг/мл $(p=1,000)$, в возрастной группе старше 3 лет $-22,7 \pm 0,6$ нг/мл и 51,9 2 ,2, нг/мл $(\mathrm{p}<0,001)$.

У детей возрастной группы младше 1 года c COVID-19-ассоциированной пневмонией средний уровень витамина D в сыворотке крови был ниже, чем в контрольной группе, в 1,1 раза, возрастной группы 1-3 года в 1,1 раза, возрастной группы старше 3 лет в 2,3 раза.

Таким образом, по результатам исследования, у детей COVID-19-ассоциированной пневмонией был низкий уровень витамина D.

Полученные нами данные совпадают с результатами ряда авторов (Yilmaz ve Sen; 2020); Tezer H., Bedir Demirdag; 2020), которые в процессе изучения взаимосвязи между уровнями витамина D и инфицированием COVID-19 выявили низкий уровень витамина D у пациентов с положительным ПЦР-тестом на COVID-19 по сравнению с контрольной группой [28,31]. Кроме того, схожие данные предоставили О.А. Громова (2020) и соавторы, проанализировав результаты систематического обзора текстов публикаций о коронавирусе, которые показали, что витамин D важен для ослабления эффектов цитокинового шторма и компенсации хронических коморбидных патологий [17].

Такую взаимосвязь можно объяснить антибактериальными и противовирусными свойствами витамина $\mathrm{D}$, который активирует многие гены против коронавирусов и других одноцепочечных РНК-вирусов (фактор активации интерферона - IFIT1, IFIT3, IFIT5, убикинин, OAS1, OAS2 и др.) [8,9,13,17].
На наш взгляд, полученные в ходе нашего исследования низкие значения витамина D у детей с COVID-19-ассоциированной пневмонией свидетельствуют в пользу ослабления у них резистентности, которая обеспечивается способностью витамина D снижать риск инфекций с помощью индукция антимикробных пептидов, которые, в свою очередь, снижают скорость репликации вирусов, уменьшают концентрации провоспалительных цитокинов и повышают концентрацию противовоспалительных цитокинов [15].

\section{Выводы}

На основании наших исследований можно сделать вывод о наличии взаимосвязи между дефицитом витамина D и COVID-19. Так, средний уровень витамина D был ниже у детей с COVID-19ассоциированной пневмонией, причем варьировал в зависимости от тяжести заболевания (более выраженные изменения наблюдались при тяжелом течении пневмонии (во II подгруппе в 1,1 раза ниже по сравнению с I подгруппой; $\left.\mathrm{p}_{1}=0,05\right)$. Также имеют место различия уровней витамина D в возрастных группах детей с COVID-19-accoциированной пневмонией: у детей раннего возраста (младше 1 года и 1-3 года) средний уровень витамина D в сыворотке крови ниже, чем в контрольной группе, в 1,1 раза, в то время, как в возрастной группе старше 3 лет - в 2,3 раза. Однако, безусловно, основные механизмы роли витамина D в процессе иммуномодуляции при COVID-19 требуют дальнейшего изучения.

Авторы заявляют об отсутствии конфликта интересов.

\section{REFERENCES/ЛITEPATУPA}

1. Akoglu HA et al. (2021). Evaluation of childhood COVID-19 cases: a retrospective analysis. Journal of Pediatric Infectious Diseases. 16: 91-98.

2. Aleksandrovich YuS, Baybarina EN, Baranov AA et al. (2020). Vedenie detey $S$ zabolevaniem, vyizvannyim novoy koronavirusnoy infektsiey (SARS-CoV-2). Pediatricheskaya farmakologiya. 2: 103-118. [Александрович ЮС, Байбарина ЕН, Баранов АА и др. (2020). Ведение детей с заболеванием, вызванным новой коронавирусной инфекцией (SARS-CoV-2). Педиатрическая фармакология. 2: 103-118].

3. Ali N. (2020). Role of vitamin D in preventing of COVID-19 infection, progression and severity. Journal of Infection and Public Health. 13: 1373-1380.

4. Amaya-Mejia, AS et at. (2013). Vitamin D deficiency in patients with common variable immunodeficiency, with autoimmune diseases and bronchiectasis. Revista Alergia Mexico. 60: 110-116.

5. ANAS. (2020). 13 A lack of vitamin $D$ and COVID-19 deaths have been identified. Institute of botanyplant \& fungal research. ISSN 2617-8001 (Print). ISSN 2664-5297 (Online).
6. Aranow C. (2011). Vitamin D and the immune system. Investigative Medicine. 59: 881-886.

7. Aysegul A, Serkan T, Yasar K. (2021). Vitamin D levels in children with COVID-19: a report from Turkey. Cambridge University Press.

8. Beard JA, Bearden A, Striker R. (2011). Vitamin D and the anti-viral state. J Clin Virol. 50 (3): 194-200.

9. Bishop E, Ismailova A, Dimeloe SK, Hewison M, White JH. (2020). Vitamin D and immune regulation: antibacterial, antiviral, anti-inflammatory. JBMR Plus: e10405. URL: https: //doi.org/10.1002/jbm4.10405.

10. Bradburne AF, Bynoe ML, Tyrrell DA. (1967). Effects of a «new» human respiratory virus in volunteers. Biol Med. 3: 767-769.

11. Carpagnano GE et al. (2020). Vitamin D deficiency as a predictor of poor prognosis in patients with acute respiratory failure due to COVID-19. Endocrinological Research. doi: 10.1007/s40618020-01370- $x$

12. Chan Yeung M, Xu RH. (2003). SARS: Epidemiology. Respirology. 8: 9-14. 
13. Charan J, Goyal JP, Saxena D, Yadav P. (2012). Vitamin D for prevention of respiratory tract infections: A systematic review and meta-analysis. Pharmacol Pharmacother. 3 (4): 300-303.

14. Darren A et al. (2021). Vitamin D status of children with paediatric inflammatory multisystem syndrome temporally associated with severe acute respiratory syndrome coronavirus 2 (PIMS-TS). British Journal of Nutrition. 12: 1-26.

15. Grant WB, Lahore H, McDonnell SL, Baggerly CA, French CB, Aliano JL, Bhattoa HP. (2020). Dokazatelstva togo, chto dobavlenie vitamina D mozhet snizit risk zarazheniya i smerti grippom i COVID-19. Pitatelnyie veschestva. 12: 988. [Grant WB, Lahore H, McDonnell SL, Baggerly CA, French CB, Aliano JL, Bhattoa HP. (2020). Доказательства того, что добавление витамина D может снизить риск заражения и смерти гриппом и COVID-19. Питательные вещества. 12: 988]. doi: 10.3390/nu12040988.

16. Griffin G, Hewison M, Hopkin J, Kenny R, Quinton R, Rhodes J, Subramanian S, Thickett D. (2020). Vitamin D and COVID-19: evidence and recommendations for supplementation. R Soc Open Sci. 7: 12.

17. Gromova OA, Torshin IYu, Gabdulina GH. (2020). Pandemiya COVID-19: zaschitnyie roli vitamina D. Sovremennaya farmakoekonomika i farmakoepidemiologiya. 13 (2): 132-145. [Громова ОА, Торшин ИЮ, Габдулина ГX. (2020). Пандемия COVID-19: защитные роли витамина D. Современная фармакоэкономика и фармакоэпидемиология. 13 (2): 132-145].

18. Hagmann S. (2020, Mar 28). COVID-19 in children: More than meets the eye. Travel Med Infect Dis. URL: https:// www.sciencedirect.com/science/article/.

19. Holick MF. (2006). Resurrection of vitamin D deficiency and rickets. Journal of Clinical Investigation. 116 (8): 2062-2072.

20. Kahn JS, McIntosh K. (2020). History and Recent Advances in Coronavirus Discovery. The Pediatric Infectious Disease. 24 (11): 223-227.

21. Lemire JM. (1992). Immunomodulatory role of 1.25-dihydroxyvitamin D3. Cellular Biochemistry. 49: 26-31.

22. Levinson M, Cevik M, Lipsitch M. (2020). Reopening Primary Schools during the Pandemic. N Engl Med. 383: 981-985.

23. Liu $X$ et al. (2014). Vitamin D modulates prostaglandin E2 synthesis and degradation in human lung fibroblasts. American Journal of Respiratory Cell and Molecular Biology. 50: 40-50.
24. Makinen M, Mykkanen J, Koskinen M, Simell V, Veijola R, Hyoty H et al. (2016). Serum 25-hydroxyvitamin D concentrations in children progressing to autoimmunity and clinical type 1 diabetes. J Clin Endocrinol Metab. 101 (2): 723-729. URL: https://doi.org/10.1210/jc.2015-3504.

25. Martens PJ et al. (2020). Vitamin D's effect on immune function. Nutrients. 12: 1248.

26. Panfili FM et al. (2021). Possible role of vitamin $D$ in Covid-19 infection in pediatric population. Journal of Endocrinological investigation. 44: 27-35.

27. Tang JW, Bahnfleth WP, Bluyssen PM et al. (2021). Dismantling myths on the airborne transmission of severe acute respiratory syndrome coronavirus-2 (SARS-CoV-2). Hosp Infect. 110: 89-96.

28. Tezer H, Bedir Demirda? T. (2020). Novel coronavirus disease (COVID-19) in children. Turkish Journal of Medical Sciences. 50: 592-603.

29. Vanherwegen AS, Gysemans C, Mathieu C. (2017). Regulation of Immune Function by Vitamin $D$ and Its Use in Diseases of Immunity.Endocrinol Metab Clin North Am. 46 (4): 1061-1094.

30. Vanherwegen AS, Gysemans C, Mathieu C. (2017, Dec). Regulation of Immune Function by Vitamin $D$ and Its Use in Diseases of Immunity. Endocrinol Metab Clin North Am. 46 (4): 1061-1094.

31. Yilmaz K, Sen V. (2020). Is vitamin D deficiency a risk factor for COVID-19 in children? Pediatr Pulmonology. 55: 3595-3601.

32. Zaharova IN, Klimov LYa, Kasyanova AN, Kuryaninova VA, Dolbnya SV, Ivanova AV et al. (2019). Sovremennyie predstavleniya ob immunotropnyih effektah vitamina D. Voprosyi prakticheskoy pediatrii. 14 (1): 7-17. [Захарова ИН, Климов ЛЯ, Касьянова АН, Курьянинова ВА, Долбня СВ, Иванова АВ и др. (2019). Современные представления об иммунотропных эффектах витамина D. Вопросы практической педиатрии. 14 (1): 7-17]

33. Zaplatnikov AL, Gorev VV. (2020). Pediatricheskie voprosyi o novoy koronavirusnoy infektsii-est li na nih segodn otvetyi? Pediatriya. Sonsilium Medicum. 1: 16-19. [Заплатников АЛ, Горев ВВ. (2020). Педиатрические вопросы о новой коронавирусной инфекции-есть ли на них сегодн ответы? Педиатрия. Consilium Medicum. 1: 16-19].

34. Zhou $Y$ et al. (2020). Pathogenic T cells and inflammatory monocytes inref inflammatory storm in severe COVID-19 patients. National Science Review. 7: 998-1002.

\section{Відомості про авторів:}

Гасанов Алекпер Газанфар огли - д.мед.н., проф. каф. дитячих хвороб ॥ Азербайджанського медичного університету. Адреса: м. Баку, вул. Е. Гасимзаде, 14. Гусейнова Ілхама Єлмар гизи - лікар-педіатр, докторант каф. дитячих хвороб II Азербайджанського медичного університету. Адреса: м. Баку, вул. Е. Гасимзаде, 14. Стаття надійшла до редакції 10.08.2021 р., прийнята до друку 09.11.2021 р. 


\title{
О.К. Колоскова, Н.К. Богуцька, С.І. Тарнавська, Х.П. Буринюк-Глов'як Особливості відповіді на базисну протизапальну терапію школярів з альтернативними запальними фенотипами бронхіальної астми
}

\author{
Буковинський державний медичний університет, м. Чернівці, Україна
}

Modern Pediatrics. Ukraine. (2021). 7(119): 40-45. doi 10.15574/SP.2021.119.40

For citation: Koloskova OK, Bogutska NK, Tarnavska SI, Buryniuk-Hloviak HP. (2021). Peculiarities of response to basic anti-inflammatory therapy of schoolchildren with alternative inflammatory phenotypes of bronchial asthma. Modern Pediatrics. Ukraine. 7(119): 40-45. doi 10.15574/SP.2021.119.40.

\begin{abstract}
Мета - оцінити ефективність тривалої протизапальної терапії інгаляційними глюкокортикостероїдами (ІГКС) у дітей за альтернативних запальних фенотипів бронхіальної астми (БА) для розроблення індивідуалізованого контролю лікування.

Матеріали та методи. Проведено комплексне обстеження 94 дітей шкільного віку з БА. За результатами цитологічного дослідження мокротиння сформовано 2 клінічні групи спостереження: I група - 38 пацієнтів із нееозинофільним (нейтрофрільним) характером запального процесу бронхів (середній вік - 11,1 2,9 року, частка хлопчиків $-52,6 \pm 8,1 \%$ ); II група — 56 дітей з еозиносрільним запаленням дихальних шляхів ( $\geq 3 \%$ еозиносрільних гранулоцитів у мокротинні), тобто еозинофільним астма-фенотипом (середній вік - 12,2 $\pm 3,2$ року, частка хлопчиків $-67,9 \pm 6,2 \%$; Р>0,05). За основними характеристиками групи спостереження були зіставлюваними. Усім пацієнтам проведено комплексне клініко-параклінічне, спірограсічне дослідження. Бальну оцінку контролю симптомів БА здійснено за допомогою анкети на початку та наприкінці курсу протизапальної базисної терапії. До опитувального листа увійшли відображені в балах клінічні ознаки БА, оцінені пацієнтами та їхніми батьки, а також шкала інструментальних досліджень за даними спірограсрічного обстеження хворих.

Результати. Показано, що вища ефрективність тривалих курсів базисної терапії ІГКС відмічалася в пацієнтів з еозинофільним характером запалення дихальних шляхів. Так, частка хворих з умовно задовільним рівнем клінічного контролю захворювання та з близькими до норми показниками спірографііі становила у II групі: до лікування IГКС - 25,0\% і 31,9\%, а після лікування - 81,3\% ( $\mathrm{P}<0,01)$ і 69,0\% ( $\mathrm{P}<0,01)$ відповідно. Отже, зростання на 69,3\% відносного ризику (ЗВР) та на 56,3\% абсолютного ризику (ЗАР) контролю БА показало виразний контролюючий ефрект ІГКС за еозинофільного характеру запалення дихальних шляхів. Мінімальна кількість хворих (МKX), яких слід пролікувати для отримання хоча б одного позитивного результату, становила 2 особи. Водночас у хворих із нейтрофільним характером запального процесу частка пацієнтів з умовно задовільним рівнем клінічного та паракінічного (за показниками спірографії) контролю захворювання становила: до лікування IКГС - 30,8\% і 30,8\%, а після лікування - 50\% (Ртмф>0,05) і 76,9\% (Ртмф<0,01) відповідно. Таке персистування клінічних проявів захворювання свідчило про недостатній рівень контролю нееозинофільної БА при лікуванні ІГКС і ставило під сумнів доцільність монотерапії цією групою нейтрофільного запалення бронхів. Про недостатній ефект протизапальної терапії ІГКС свідчило і те, що ЗВР задовільного рівня клінічного контролю становило $38,4 \%, 3 \mathrm{AP}-19,2 \%$, а MKX - 6 хворих.

Висновки. У пацієнтів з еозинофільним фенотипом БА застосування тривалих курсів ІГКС підвищувало шанси досягнення контролю над захворюванням, водночас шанси поліпшення вентиляційної функції легень відзначалися також при нейтрофільному фенотипі захворювання.

Дослідження виконано відповідно до принципів Гельсінської декларації. Протокол дослідження ухвалено Локальним етичним комітетом зазначеної в роботі установи. На проведення досліджень отримано інформовану згоду батьків дітей.
\end{abstract}

Автори заявляють про відсутність конфрлікту інтересів.

Ключові слова: бронхіальна астма, діти, базисна протизапальна терапія

\section{Peculiarities of response to basic anti-inflammatory therapy of schoolchildren with alternative inflammatory phenotypes of bronchial asthma O.K. Koloskova, N.K. Bogutska, S.I. Tarnavska, H.P. Buryniuk-Hloviak \\ Bukovynian State Medical University, Chernivtsi, Ukraine}

Purpose - to evaluate the effectiveness of long-term anti-inflammatory therapy with inhaled glucocorticosteroids in children with alternative inflammatory phenotypes of bronchial asthma (BA) for the development of individualized control treatment.

Materials and methods. A comprehensive survey of 94 school-age children with BA was conducted. According to the results of cytological examination of sputum, 2 clinical observation groups were formed. The first group of patients was formed by 38 patients with non-eosinophilic (neutrophilic) nature of the inflammatory process of the bronchi (mean age $-11.1 \pm 2.9$ years, the proportion of boys $-52.6 \pm 8.1 \%$ ), and the second group -56 children with eosinophilic type of airway inflammation $(3 \%$ or more of eosinophilic granulocytes in sputum), ie eosinophilic asthma phenotype (mean age $12.2 \pm 3.2(P>0.05)$ years, the proportion of boys $-67.9 \pm 6.2 \%, P>0.05)$. According to the main characteristics of the observation group could be compared. All patients underwent a comprehensive clinical and paraclinical (spirographic) examination. Scoring control of BA symptoms was performed using a questionnaire at the beginning and at the end of the course of anti-inflammatory basic therapy. The questionnaire included the clinical signs of BA reflected in the scores, which were evaluated by patients and their parents, as well as the scale of instrumental studies according to the spirographic examination of patients.

Results. The paper shows that the best effect of long-term courses of basic therapy with inhaled glucocorticosteroids (ICS) was observed in patients with eosinophilic airway inflammation. Thus, the share of patients with a relatively satisfactory level of clinical control of the disease and with close to normal spirographic indicators was in group II: before the course of treatment with inhaled corticosteroids $25.0 \%$ and $31.9 \%$, and after treatment $-81.3 \%(P<0,01)$ and $69.0 \%(P<0.01)$, respectively. Thus, an increase of $69.3 \%$ in relative risk (IRR) and $56.3 \%$ in absolute risk (IAR) of BA control reflected a pronounced control effect of inhaled corticosteroids in the eosinophilic nature of airway inflammation. The minimum number of patients needed to treat (NNT) in order to obtain at least one positive result was 2 . At the same time, in patients with neutrophilic inflammatory process, the proportion of patients with a relatively satisfactory 
level of clinical and paraclinical (according to spirography) disease control was: before the appointment of ICS - $30.8 \%$ and $30.8 \%$, and after treatment $50 \%$ ( $P_{\text {Fisher's exact test }>0.05)}$ and $76.9 \%$ (PFisher's exact test $<0.01$ ), respectively. This persistence of clinical manifestations of the disease indicated an insufficient level of control of non-eosinophilic BA in the treatment of inhaled corticosteroids and questioned the feasibility of monotherapy with this group of neutrophilic bronchitis. The insufficient effect of anti-inflammatory therapy with inhaled corticosteroids was evidenced by the fact that IRR of satisfactory level of clinical control was $38.4 \%$, IAR $-19.2 \%$, and NNT -6 patients.

Conclusions. In patients with the eosinophilic phenotype of BA, the use of long courses of inhaled glucocorticosteroids led to an increased chance of achieving disease control, while the chances of improving of the pulmonary function tests were also observed in the neutrophilic phenotype of the disease.

The research was carried out in accordance with the principles of the Helsinki declaration. The study protocol was approved by the Local ethics committee of the participating institution. The informed consent of the patient was obtained for conducting the studies.

No conflict of interest was declared by the authors.

Key words: bronchial asthma, children, basic anti-inflammatory therapy.

\section{Особенности ответа на базисную противовоспалительную терапию школьников с альтернативными воспалительными фенотипами бронхиальной астмы}

Е.К. Колоскова, Н.К. Богуцкая, С.И. Тарнавская, К.П. Бурынюк-Гловьяк

Буковинский государственный медицинский университет, г. Черновцы, Украина

Цель - оценить эффективность длительной противовоспалительной терапии ингаляционными глюкокортикостероидами (ИГКС) у детей при альтернативных воспалительных френотипах бронхиальной астмы (БА) для разработки индивидуализированного контроля лечения.

Материалы и методы. Проведено комплексное обследование 94 детей школьного возраста с БА. По результатам цитологического исследования мокроты сфрормированы 2 клинические группы наблюдения: I группа - 38 пациентов с неэозиносилььым (нейтрофильным) характером воспалительного процесса бронхов (средний возраст $-11,1 \pm 2,9$ года, доля мальчиков $-52,6 \pm 8,1 \%$ ), II группа -56 детей с эозиносрильным воспалением дыхательных путей (3\% и более эозинофильных гранулоцитов в мокроте), (средний возраст - 12,2士3,2 года, доля мальчиков $67,9 \pm 6,2 \% ;$ Р $>0,05)$. По основным характеристикам группы наблюдения были сопоставимы. Всем пациентам проведено комплексное клиникопараклиническое, спирографическое исследование. Бальная оценка контроля симптомов БА осуществлена с помощью анкеты в начале и в конце курса противовоспалительной базисной терапии. В опросник вошли отраженные в баллах клинические признаки БА, оцененные пациентами и их родителями, а также шкала инструментальных исследований по данным спирографического обследования больных.

Результаты. В работе показано, что лучшая эфффективность длительных курсов базисной терапии ИГКС отмечалась у пациентов с эозинофильным характером воспаления дыхательных путей. Так, доля больных с условно удовлетворительным уровнем клинического контроля заболевания и с близкими к норме показателями спирографии составляла во II группе: до лечения ИГКС $-25,0 \%$ и 31,9\%, после лечения - 81,3\% (P<0,01) и $69,0 \%(P<0,01)$ соответственно. Следовательно, увеличение на 69,3\% относительного риска (УОР) и на 56,3\% абсолютного риска (УАР) контроля БА отражали отчетливую контролирующую эфффективность ИГКС при эозиносрильном характере воспаления дыхательных путей. Минимальное количество больных (МКБ), которых следует пролечить для получения хотя бы одного положительного результата, составляло 2. В то же время у больных с нейтрофильным характером воспалительного процесса доля пациентов с условно удовлетворительным уровнем клинического и паракинического (по показателям спирографии) контроля заболевания составляла: до лечения ИКГС - 30,8\% и 30,8\%, а после лечения - 50\% (Ртмф>0,05) и 76,9\% (Ртмф<0,01) соответственно. Такое персистирование клинических проявлений заболевания свидетельствовало о недостаточном уровне контроля неэозинофильной БА при лечении ИГКС и подвергало сомнению целесообразность монотерапии этой группой нейтрофильного воспаления бронхов. О недостаточном эффректе противовоспалительной терапии ИГКС свидетельствовало и то, что УВР удовлетворительного уровня клинического контроля составляло $38,4 \%$, УАР - 19,2\%, а МКБ - 6 больных.

Выводы. У пациентов с эозинофильным фенотипом БА применение длительных курсов ИГКС приводило к росту шансов достижения контроля над заболеванием, в то же время шансы улучшения вентиляционной функции легких отмечались также при нейтросильном фенотипе заболевания. Исследование выполнено в соответствии с принципами Хельсинкской декларации. Протокол исследования одобрен Локальным этическим комитетом участвующего учреждения. На проведение исследований получено информированное согласие родителей детей.

Авторы заявляют об отсутствии конфрликта интересов.

Ключевые слова: бронхиальная астма, дети, базисная противовоспалительная терапия.

\section{Вступ}

$\mathrm{B}$ аріабельність клінічних характеристик прогностичних факторів, непоодинокі випадки відсутності очікуваного ефекту від стандартного профілактичного лікування (стероїдна резистентність, токсичність швидкоі тривалодіючих селективних $\beta_{2}$-адреноміметиків, чутливість до анти-IgE) підтверджують думку, що астма - це синдром, який охоплює декілька варіантів або фенотипів [18,19]. Алергічна (IgE опосередкована) сенсибілізація організму за активної участі Th2 CD4+ лімфоцитів і з наступним розвитком IL-5 опосередкованого еозинофільного запалення дихальних шляхів (ДШ) призводить до підвищення бронхіальної реактивності [1,14] i, як наслідок, до обструкції дихальних шляхів. Однак на цей час існуе все більше доказів, які свідчать, що до реалізації гіперреактивності ДШ, яка характеризує власне БА, можуть залучатися інші запальні механізми. Дослідження, проведені для визначення характеру запалення ДШ у пацієнтів, хворих на БА, із застосуванням індукції мокротиння i/або бронхоальвеолярного лаважу, показали, 
що в значній частці випадків він відрізняється від звичного «класичного» алергічного [8], і загострення астми можуть виникати без посилення еозинофільного запалення $[3,7,13]$.

Водночас основними біомаркерами БА є еозинофіли периферичної крові. Еозинофіли являють собою насамперед тканинні клітини, що ускладнює вивчення їх функціональних особливостей [10]. Крім того, рівень циркулюючих еозинофілів залежить від добового ритму секреції гідрокортизону, а також пов'язаний із певними циркадіадними ритмами, максимум якого припадає на нічний час, мінімум - на ранковий. Еозинофілію периферичної крові як патогенетичний синдром БА розглядали ще на початку $\mathrm{XX}$ ст. [4,9], однак роль цих клітин у пошкодженні епітелію та інших феноменах визначили лише в останні його десятиліття [5]. Судження про значення еозинофілії крові та тканин до останнього часу мали суперечливий характер. Поряд із захисною роллю $[12,16]$, яка полягає в тому, що еозинофіли продукують арилсульфатазу - фермент антилейкотрієнової дії, ім властива досить вагома пошкоджувальна функція [5,6]. У гранулах еозинофілів містяться лужні білки, головні з яких - великий основний протеїн, еозинофільний катіонний протеїн, еозинофільна пероксидаза, еозинофільний нейротоксин. Прозапальні властивості цих клітин проявляються завдяки дії саме вищезазначених речовин, яким властива цитотоксичність, стимуляція дегрануляції опасистих клітин і базофілів [2]. Тобто визначення вмісту катіонних білків, пероксидази може свідчити про ступінь активації основних прозапальних клітин алергічного запалення, а через це непрямо про тяжкість і виразність запального процесу. У літературних джерелах більше уваги приділяють визначенню цих цитотоксичних речовин у сироватці крові та вказують на зв'язок між вмістом їх у сироватці крові й тяжкістю стану хворого при алергічному процесі $[8,15]$.

Ефекторними клітинами запального процесу в бронхах можуть виступати як еозинофільні, так і нейтрофільні гранулоцити, проте роль еозинофільних гранулоцитів у розвитку БА є наразі достатньо дискутабельною. Однак, враховуючи прозапальну роль цих клітин у ДШ $\mathrm{i}$, як наслідок, формування гіперчутливості останніх до специфічних та неспецифічних подразників, значення еозинофілів не заперечується у формуванні одного з фенотипів захворювання - атопічної астми. Отже, еозинофільні гранулоцити ідентифіковані як головна мішень терапевтичного втручання при БА [15].
Mema дослідження - оцінити ефективність тривалої протизапальної терапії інгаляційними глюкокортикостероїдами (ІГКС) у дітей за альтернативних запальних фенотипів бронхіальної астми (БА) для розроблення індивідуалізованого контролю лікування.

\section{Матеріали та методи дослідження}

В умовах пульмоалергологічного відділення КМУ «Обласна дитяча клінічна лікарня м. Чернівці» методом простої випадкової вибірки обстежено 94 дитини шкільного віку з БА. За результатами цитологічного дослідження мокротиння сформовано дві клінічні групи спостереження. Першу (I) групу хворих становили 38 пацієнтів із нееозинофільним (нейтрофільним) характером запального процесу бронхів, а другу (II) - 56 дітей з еозинофільним запаленням ДШ ( $\leq 3 \%$ еозинофільних гранулоцитів у мокротинні), тобто еозинофільним астмафенотипом [15].

За основними клінічними ознаками групи порівняння були зіставними. Так, до I групи увійшло $20(52,6 \pm 8,1 \%)$ хлопчиків і 18 $(47,4 \pm 8,1 \%)$ дівчаток, а середній вік хворих становив 11,1 22,9 року. У ІІ клінічній групі порівняння хлопчиків було $38(67,9 \pm 6,2 \%, \mathrm{P}>0,05)$ та $18(32,1 \pm 6,2 \%, \mathrm{P}>0,05)$ дівчаток, а середній вік пацієнтів становив $12,2 \pm 3,2(\mathrm{P}>0,05)$ року. У сільській місцевості проживали: у I групі $26(68,4 \pm 7,5 \%)$ дітей, а в II групі 34 (60,7 $\pm 6,5 \%)$ хворі; $\mathrm{P}>0,05$. За результатами клінічного обстеження в I групі атопічну форму захворювання діагностовано у $15(39,5 \pm 7,9 \%)$ дітей, змішану у $23(60,5 \pm 7,9 \%)$ хворих, а в II групі - відповідно у $41 \quad(73,2 \pm 5,9 \%)$ пацієнта $(\mathrm{P}<0,01)$ i $15(26,8 \pm 5,9 \%)$ пацієнтів; $\mathrm{P}<0,01$.

У I клінічній групі інтермітуючий перебіг зареєстровано у $9(23,7 \pm 6,9 \%$, Р>0,05), перси-

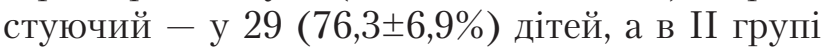
порівняння - відповідно у $12(21,4 \pm 5,5 \%)$ та 44 хворих (78,6 $\pm 5,5 \%)$; $\mathrm{P}>0,05$. За ступенем тяжкості захворювання у I групі легку БА відмічено в $9(23,7 \pm 6,9 \%)$ хворих, середньотяжку у $24(63,2 \pm 7,8 \%)$ дітей, тяжку у $5(13,1 \pm 5,5 \%)$ пацієнтів; у II групи порівняння - відповідно у 17 (30,4 $46,2 \%, \mathrm{P}>0,05)$, $23(41,1 \pm 6,6 \%, \quad \mathrm{P}<0,05)$ та $16 \quad(28,5 \pm 6,0 \%$, $\mathrm{P}>0,05)$ хворих.

Бальну оцінку контролю симптомів БА здійснено за допомогою анкети на початку і наприкінці курсу протизапальної базисної терапії. До опитувального листа увійшли відображені 
Таблиия 1

Порівняльна оцінка контролю нейтрофільного фенотипу бронхіальної астми в дітей під впливом тривалого протизапального лікування інгаляційними глюкокортикостероїдами

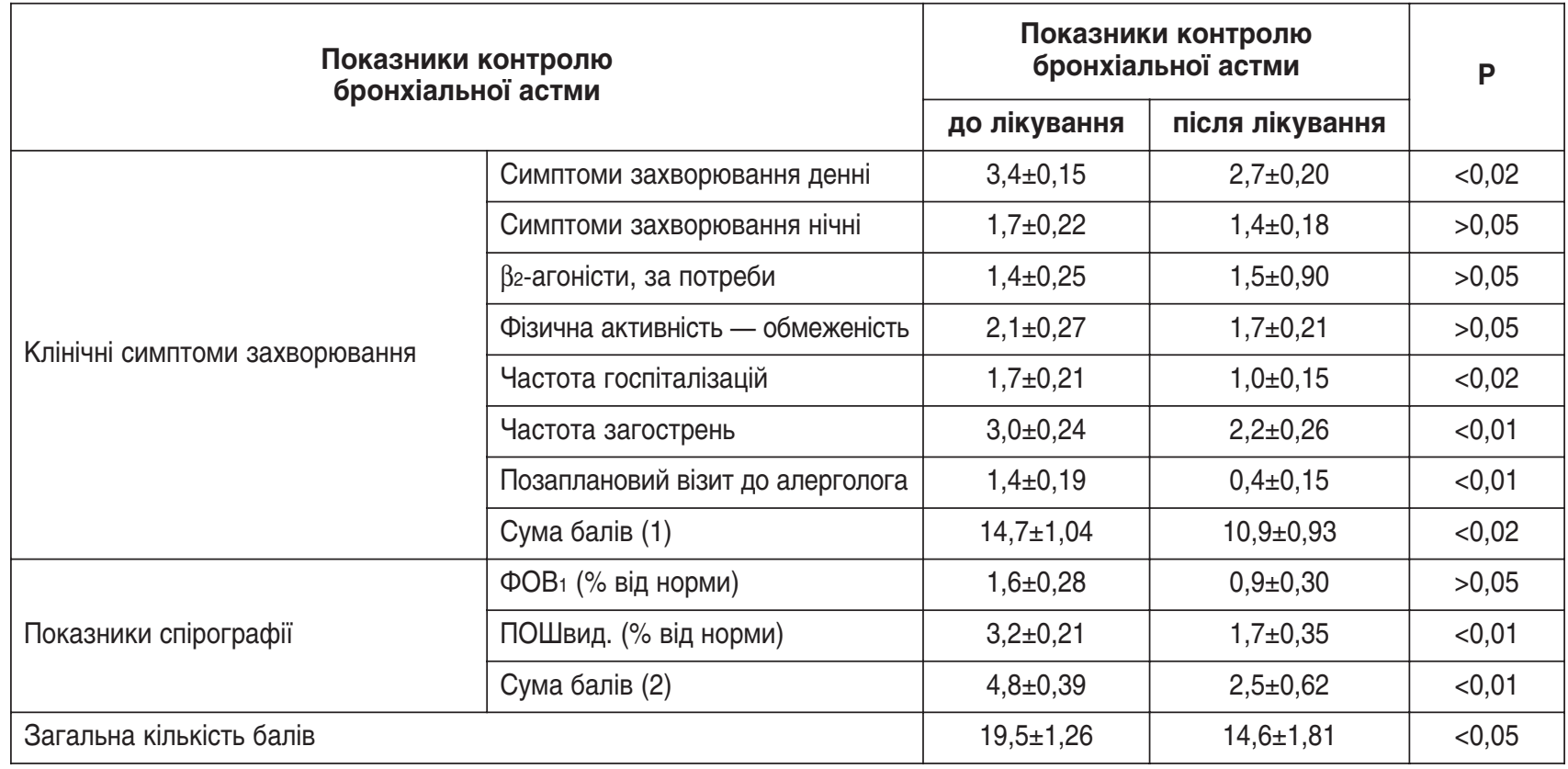

Примітки: ФОВ1 - форсований об'єм видиху за першу секунду; ПОШвид. - пікова об'ємна швидкість видиху.

в балах клінічні ознаки БА, оцінені (у межах 0-4 бали) пацієнтами та їхніми батьками, а також шкала інструментальних досліджень [11,17], яку заповнював лікуючий лікар за даними спірографічного обстеження хворих (оцінка - у межах 0-4 бали). Ефективність лікування оцінено за декількома критеріями: загальною кількістю балів, що вираховували при додаванні балів самооцінки хворими їхнього клінічного стану (сума балів 1) та результатів спірографічного обстеження (сума балів 2). Кількість балів свідчила про рівень контролю БА (чим гірший контроль, тим вища сума балів), а також про ефективність терапії (чим ефективніше лікування, тим нижча кількість балів після проведеної терапії). Слід зазначити, що прихильність до запропонованої терапії (комплаєнс) становив 90,5\%.

Дослідження виконано відповідно до принципів Гельсінської декларації. Протокол дослідження ухвалено Локальним етичним комітетом зазначеної в роботі установи. На проведення досліджень отримано інформовану згоду батьків, дітей.

\section{Результати дослідження та їх обговорення}

Проведено оцінку тривалої (від 3 місяців) базисної протизапальної терапії препаратами ІГКС у хворих клінічних груп порівняння з урахуванням спірографічних показників. При цьому важливим є те, що за клінічними та спі- рографічними даними вихідний рівень контролю захворювання в пацієнтів обох груп спостереження був однаковим.

Показано, що вища ефективність тривалих курсів базисної терапії ІГКС відмічалася в пацієнтів з еозинофільним характером запалення ДШ. Так, загальну кількість балів понад 13 зареєстровано у 53,8\% пацієнтів I групи та

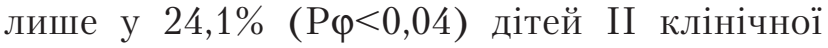
групи. Недостатній рівень контролю нейтрофільної БА пояснювався збереженням частих денних і нічних симптомів захворювання, що потребували додаткового (майже через день) застосування $\beta_{2}$-агоністів короткої дії. Так, на тлі застосування ІГКС необхідність додаткового вживання сальбутамолу (понад 4 рази на тиждень) виникала у 16,8\% дітей II клінічної групи та в 46,1\% пацієнтів групи порівняння $\left(\mathrm{P}_{\text {тмФ }}<0,01\right)$. Водночас недостатній контроль БА, зумовленої нейтрофіл-асоційованим запаленням ДШ, призводив до обмеження фізичної активності дітей та виникнення загострень понад 3 рази на рік.

Курсове застосування ІГКС чинило значний ефект як на клінічні прояви еозинофільної БА, так і на спірографічні показники контролю захворювання. Так, частка хворих з умовно задовільним рівнем клінічного контролю захворювання (сума балів $(1)<12)$ та з близькими до норми показниками спірографії (сума балів $(2)<4)$ становила у II групі: до лікування IГКС - 
25,0\% і 31,9\%, а після лікування - 81,3\% $(\mathrm{P}<0,01)$ і $69,0 \%(\mathrm{P}<0,01)$ відповідно. Отже, зростання на $69,3 \%$ відносного ризику (3ВР) та на 56,3\% абсолютного ризику (3АР) контролю БА, що визначали як збільшення завдяки проведеному лікуванню частки хворих із кількістю балів загальної клінічної оцінки $<12$, відображали виразний контролюючий ефект ІГКС за еозинофільного характеру запалення ДШ. Мінімальна кількість хворих (МКХ), яких слід пролікувати для отримання хоча б одного позитивного результату, становила 2.

Для поліпшення вентиляційної функції легень, що визначали як досягнення рівня контролю за даними спірограми (сума балів (2) $<4)$, пролікували ІГКС 3 дітей, що страждають на еозинофільну БА. При цьому ЗВР становило 53,8\%, а ЗАР - 37,1\%. Такі показники свідчили про високу ефективність протизапальної терапії еозинофільного типу БА за допомогою ІГКС, але у вагомої частки хворих не вдалося досягти бажаного рівня контролю захворювання.

У таблиці 1 наведено показники контролю БА на початку і наприкінці курсу ІГКС у дітей із нейтрофільним характером запалення ДШ.

Аналіз наведених даних засвідчив певний позитивний ефект тривалої терапії нейтрофільної БА за допомогою ІГКС у І клінічній групі, проте в цих пацієнтів зберігалися денні та непоодинокі нічні симптоми захворювання, що обмежувало фізичну активність, спричиняло часті загострення й додаткове застосування бронходилататорів. Про недостатній терапевтичний вплив ІГКС на нейтрофільну БА свідчило незначне зростання кількості хворих із задовільним рівнем контролю. Так, у I групі частка пацієнтів з умовно задовільним рівнем клінічного контролю захворювання (сума балів (1) <12) становила: до лікування ІКГС $-30,8 \%$, а після лікування $-50 \%$ (РтмФ>0,05). Таке персистування клінічних проявів захворювання свідчило про недостатній рівень контролю нееозинофільної БА за допомогою лікування ІГКС і ставило під сумнів доцільність монотерапії цією групою нейтрофільного запалення бронхів. Про недостатній ефект протизапальної терапії ІГКС свідчило і те, що ЗВР задовільного рівня клінічного контролю (сума балів $(1)<12)$ становило $38,4 \%, 3 \mathrm{AP}-19,2 \%$, а МКХ -6 хворих.

Водночас у хворих на нейтрофільну БА значно поліпшилися спірографічні показники на тлі
Таблиия 2

Показники ризику контролю бронхіальної астми тривалим курсом лікування інгаляційними глюкокортикостероїдами у дітей груп порівняння

\begin{tabular}{|l|c|c|c|}
\hline Клінічна група & Показники & AP, $\%$ & ВШ (95\% ДІ) \\
\hline \multirow{3}{*}{ | } & Сума балів (1) <12 & 20,0 & $2,3(0,7-7,0)$ \\
\cline { 2 - 4 } & Сума балів (2) <4 & 41,0 & $7,5(1,6-34,8)$ \\
\hline \multirow{2}{*}{$\|$} & Сума балів (1) <12 & 57,0 & $13,0(4,9-34,5)$ \\
\cline { 2 - 4 } & Сума балів (2) <4 & 35,0 & $4,7(1,8-12,9)$ \\
\hline
\end{tabular}

лікування. Так, у I групі частка хворих із близькими до норми показниками спірографії (сума балів (2) <4) становила: до застосування ІГКС - 30,8\%, а після протизапальної терапії $76,9 \%$ (РтмФ<0,01). При цьому ЗВР відновлення бронхіальної прохідності майже до норми становило $60 \%, 3 \mathrm{AP}-46,1 \%$, а МКХ - 3 пацієнти.

Враховуючи значне поліпшення вентиляційної функції легень у хворих із нейтрофільним характером запалення ДШ під впливом базисної терапії ІГКС, при тяжкій, асоційованій зі зниженою функцією легень, нееозинофільній БА застосування ІГКС є обгрунтованим.

У таблиці 2 наведено показники ризику контролю астми ІГКС при еозинофільному та нейтрофільному варіантах запалення ДШ.

Отримані дані підтвердили виразніший клінічний ефект ІГКС за еозинофільної БА та водночас засвідчили високу вірогідність поліпшення вентиляційної функцій легень за нейтрофільного фенотипу захворювання на тлі такої терапії.

\section{Висновки}

У дітей з еозинофільним фенотипом БА тривале застосування ІГКС призводило до ЗВР на $69,3 \%$ та 3 АР на 56,3\% показників клінічного контролю БА завдяки лікуванню та поліпшенню вентиляційної функції легень: ЗВР $53,8 \%, 3 \mathrm{AP}-37,1 \%$.

У дітей з нейтрофільним запальним фенотипом БА виявився недостатній ефект протизапальної терапії ІГКС, про що свідчило і те, що ЗВР задовільного рівня клінічного контролю становило 38,4\%, ЗАР - 19,2\%, при МКХ 6 пацієнтів.

За наявності нейтрофільного фенотипу БА застосування ІГКС підвищувало шанси поліпшення вентиляційної функції легень у 7,5 разу.

Автори заявляють про відсутність конфлікту інтересів. 


\section{REFERENCES/ЛITEPATУPA}

1. Bao K, Reinhardt RL. (2015). The differential expression of IL-4 and IL-13 and its impact on type-2 immunity. Cytokine. 75 (1): 25-37.

2. Besh LV. (2011). Bronchial asthma in young children: features of diagnosis and treatment. Zdorovia Ukrainy. 2 (14): 45-46. [Беш ЛВ. (2011). Бронхіальна астма у дітей раннього віку: особливості діагностики й лікування. Здоровья України. 2 (14): 45-46].

3. Campo P, Rodriguez F, Sanchez-Garcia S. (2013). Phenotypes and Endotypes of Uncontrolled Severe Asthma: New Treatments. J Inves. Allergol Clin Immunol. 23 (2): 76-88.

4. Carr TF, Zeki AA, Kraft M. (2018). Eosinophilic and Noneosinophilic Asthma. Am J Respir Crit Care Med. 197 (1): 22-37.

5. Castro-Rodriguez, Jose A. (2011). The Asthma Predictive Index. Curr Allergy Clin Immunol. 11 (3): 157-161.

6. GINA. (2012). Global Strategy for Asthma Management and Prevention (updated 2012). URL: http://www.ginasthma.org/ local/uploads/files/GINA_Report_2012Feb13.pdf.

7. Green RH, Pavord S. (2012). Stability of inflammatory phenotypes in asthma. Thorax. 2: 46-57.

8. Hesselmar B, Bergin AM, Park H. (2010). Interleukin-4 receptor polymorphisms in asthma and allergy: relation to different disease phenotypes. Acta Paediatrica. 99 (3): 399-403.

9. Hesselmar B, Enelund AC, Eriksson B. (2012). The Heterogeneity of Asthma Phenotypes in Children and Young Adults. J Allergy. URL: http://www.hindawi.com/journals/ja/2012/163089.

10. Lanz MJ, Gilbert I, Szefler SJ, Murphy KM. (2019). Can early intervention in pediatric asthma improve long-term outcomes? A question that needs an answer. Pediatr Pulmonol. 54 (3): 348-357.
11. Li JT, Oppenheimer J, Bernstein IL, Nicklas RA. (2005). Attaining optimal asthma control: a practice parameter. J Allergy Clin Immunol. 116 (5): $3-11$.

12. Mendez-Enriquez E, Hallgren J. (2019). Mast Cells and Their Progenitors in Allergic Asthma Front Immunol. 10: 821-825.

13. Nadif R, Siroux V, Oryszczyn MP, Ravault C. (2009). Heterogeneity of asthma according to blood inflammatory patterns. Thorax. 64: 374-380.

14. Okhotnikova OM. (2011). Bronchial astma in children. Mystetstvo likuvannia. 1 (77): 41-54. [Охотнікова ОМ. (2011). Бронхіальна астма у дітей. Мистецтво лікування. 1 (77): 41-54].

15. Persson C. (2014). Primary lysis of eosinophils in severe desquamative asthma. Clin \& Exper Allergy. 44 (2): 173-183.

16. Qiu Y, Zhu J, Bandi V, Guntupalli KK, Jeffery PK. (2007). Bbronchial mucosal inflammation and upregulation of $\mathrm{CXC}$ chemoattractants and receptors in severe exacerbations of asthma. Thorax. 62: 475-482.

17. Schatz M, Sorkness CA, Li JT. (2006). Asthma Control Test: Reliability, validity, and responsiveness in patients not previously followed by asthma specialists. J Allergy Clin Immunol. 117 (3): 549-556.

18. Umanets TR, Lapshyn VF. (2014). Modern concept of bronchial asthma phenotyping. Zdorovia Ukrainy. 1 (28): 52-54. [Уманець ТР, Лапшин ВФ. (2014). Сучасна концепція фенотипування бронхіальної астми. Здоров'я України. 1 (28): 52-54].

19. Weiss ST. (2012). New approaches to personalized medicine for asthma: Where are we? J Allergy Clin Immunol. 129: 327-334.

\section{Відомості про авторів:}

Колоскова Олена Костянтинівна - дмед.н., проф., зав каф. періатрії та дитячих інфекційних хвороб Буковинського Дму Адреса: м. Чернівці, вул. Руська, 207А тел : (0372) 575-660.

https://orcid.org/0000-0002-4402-8756.

Богуцька Наталія Казимирівна - к.мед.н., доц. каф. педіатрії та дитячих інфекційних хвороб Буковинського ДМУ. Адреса: м. Чернівці, вул. Руська, 207А; тел.: (0372)575-660. https://orcid.org/0000-0001-6268-1452.

Тарнавська Світлана Іванівна - к.мед.н., доц. каф. педіатрії та дитячих інфекційних хвороб Буковинського ДМУ. Адреса: м. Чернівці, вул. Руська, 207А; тел.: (0372)575-660. https://orcid.org/0000-0003-1046-8996.

Буринюк-Глов'як Христина Петрівна - асистент каф. педіатрії та дитячих інфекційних хвороб Буковинського ДМу. Адреса: м. Чернівці, вул. Руська, 207А; тел.: (0372)575-660. https://orcid.org/0000-0003-2062-1763.

Стаття надійшла до редакції 06.07.2021 р., прийнята до друку 09.11.2021 p.

\section{$19^{\text {th }}$ International Conference on Paediatrics and Pediatric Cardiology}

Pediatric meetings consistently been at the unmistakable quality to help and support the logical and techno analysts. After a fruitful occasion during 2021 we are special to report Pediatric Cardiology 2022 named $1^{\text {th }}$ International Conference on paediatrics and Pediatric Cardiology which is booked on May 18-9, 2022 online course/virtual occasion.

Online occasion plans to help all researchers and researchers from everywhere the world in conveying their thoughts by a protected and effective occasion. The objective of online occasion is to make global online occasions as protected as conceivable from general wellbeing dangers of the Covid-19 with specialized help to have for occasions. Gathering Series consistently been at the bleeding edge to help and support the logical and techno analysts and will be in future as well. We invite the support of Directors, Presidents, CEOs, delegates and modern chiefs from Pediatric Pharmaceutical and Healthcare areas making it a stage for worldwide systems administration advancing business connections, trading thoughts, energizes the impending explores and scientists

An online course is a drawing in online occasion where a speaker or little gathering of speakers, conveys a show to an enormous crowd where in the crowd who join in live can type questions/leave criticism utilizing the accessible intelligent apparatuses. It considers live association among moderator and the online participants. Participants can collaborate by means of talk and informing and utilize their receivers to talk during the Q\&A segment. Once enrolled for the online class you get an email (typically 2 days before the occasion) with a web address, from PC or PC click on the web address of the online course.

More information: https://pediatriccardiology.conferenceseries.com/europe/ 


\title{
О.В. Дутчук', З.Р. Кочерга', В.М. Волошинович', Ю.І. Алексеєва', Ю.С. Томащук ${ }^{2}$ \\ Клінічний випадок легеневої бластоми в дитини як маскування негоспітальної пневмонії
}

\author{
1'вано-Франківський національний медичний університет, Україна \\ ${ }^{2} \mathrm{KHП} \mathrm{«Івано-Франківська} \mathrm{обласна} \mathrm{дитяча} \mathrm{клінічна} \mathrm{лікарня} \mathrm{Івано-Франківської} \mathrm{обласної} \mathrm{ради»,} \mathrm{Україна}$
}

Modern Pediatrics. Ukraine. (2021). 7(119): 46-50. doi 10.15574/SP.2021.119.46

For citation: Dutchuk OV, Kocherha ZR, Voloshynovych VM, Alekseeva Yul, Tomashchuk YuS. (2021). Clinical case of pulmonary blastoma in a child as a disguise of community-acquired pneumonia. Modern Pediatrics. Ukraine. 7(119): 46-50. doi 10.15574/SP.2021.119.46.

У цей час проблема діагностики плевролегеневої бластоми в дітей залишається актуальною, оскільки зазначена патологія часто маскується під інші нозології, зокрема пневмонії, і діагностується вкрай тяжко. Наразі немає патогномонічної клінічної симптоматики, специфічних діагностичних критеріїв вказаного захворювання, майже 60\% пацієнтів мають неспецифічні симптоми. У статті наведено рідкісний клінічний випадок біфазної легеневої бластоми в дитини, яка перебувала на обстеженні та лікуванні в КНП «вано-Франківська обласна дитяча клінічна лікарня Івано-Франківської обласної ради». Виявлено основні клінічні прояви, діагностику та напрями лікування біфазної бластоми легень у дитини на підставі спостереження за дівчинкою 5-річного віку, госпіталізованою до стаціонару з приводу гострого абдомінального болю, болю в грудній клітці та кашлю. Після проведених клініко-лабораторних та інструментальних методів обстеження діагностовано правобічну пневмонію, ексудативний плеврит. Комплекс проведених лікувальних заходів не дав очікуваного позитивного результату, поліпшення стану пацієнта. У зв'язку з підозрою на новоутворення грудної клітки дитині призначено додаткове обстеження. Встановлено, що найінформативнішим методом верифікації діагнозу легеневої бластоми $€$ мультиспіральна комп'ютерна томографрія з внутрішньовенним болюсним контрастуванням та імуногістохімічне дослідження біоптату. Вказано методи лікування, застосовувані в цьому випадку, зокрема проведення протизапальної та поліхіміотерапії за схемою, радикальний метод лікування в Національному інституті раку м. Київ - оперативне втручання пневмонектомія справа з резекцією перикарда. Дитина на цей час перебуває в стадії стійкої ремісії впродовж 4,5 року. Описаний клінічний випадок показує труднощі діагностики бластоми легень у дітей через відсутність типових клінічних проявів.

Дослідження виконано відповідно до принципів Гельсінської декларації. На проведення досліджень отримано інформовану згоду батьків дитини.

Автори заявляють про відсутність конфлікту інтересів.

Ключові слова: діти, пневмонія, бластома, пульмонологія, діагностика, лікування.

\section{Clinical case of pulmonary blastoma in a child as a disguise of community-acquired pneumonia}

O.V. Dutchuk', Z.R. Kocherha', V.M. Voloshynovych', Yu.I. Alekseeva', Yu.S. Tomashchuk ${ }^{2}$

'Ivano-Frankivsk National Medical University, Ukraine

${ }_{2}^{2}$ Municipal non-profit enterprise Ivano-Frankivsk Regional Children's Clinikal Hospital Ivano-Frankivsk Regional Council, Ukraine

Currently, the problem of diagnosing pleuropulmonary blastoma in children remains relevant, because this pathology often runs under the guise of other nosologies, including pneumonia, and is extremely difficult to diagnose. Currently there are no pathognomonic clinical symptoms, specific diagnostic criteria for this disease, almost $60 \%$ of patients have nonspecific symptoms. This article presents a rare clinical case of biphasic pulmonary blastoma in a child who was examined and treated at the Ivano-Frankivsk Regional Children's Clinikal Hospital Ivano-Frankivsk Regional Council. The main clinical manifestations, diagnosis and treatment of biphasic blastoma of the lungs in a child based on the observation of a 5-year-old girl who was hospitalized for acute abdominal pain, chest pain and cough. After clinical — laboratory and instrumental methods of examination, right-sided pneumonia and exudative pleurisy were diagnosed. The set of treatment measures did not give the expected positive effect, improving the patient's condition. Additional testing is required for suspected breast cancer. It has been established that the best method for verifying the diagnosis of pulmonary blastoma is multislice computed tomography with intravenous bolus contrast and immunohistochemical examination of the biopsy. The methods of treatment used in this case, including anti-inflammatory and polychemotherapy according to the scheme, the use of radical treatment at the National Cancer Institute in Kyiv — surgery right pneumonectomy with pericardial resection. The child is currently in stable remission for 4,5 years. The described clinical case demonstrates the difficulty of diagnosing lung blastoma in children due to the lack of typical clinical manifestations.

The research was carried out in accordance with the principles of the Helsinki declaration. The informed consent of the patient was obtained for conducting the studies. No conflict of interest was declared by the authors.

Key words: children, pneumonia, blastoma, pulmonology, diagnosis, treatment.

\section{Клинический случай легочной бластомы у ребенка как маскировка внебольничной пневмонии О.В. Дутчук', З.Р. Кочерга', В.М. Волошинович', Ю.И. Алексеева', Ю.С. Томащук² \\ 'Ивано-Франковский национальный медицинский университет, Украина \\ КНП «Ивано-Франковская областная детская клиническая больница Ивано-Франковского областного совета», Украина}

В настоящее время проблема диагностики плевролегочной бластомы у детей остается актуальной, поскольку указанная патология часто маскируется под другие нозологии, в частности пневмонии, и диагностируется крайне затруднительно. Пока нет патогномонической клинической симптоматики, специфических диагностических критериев указанного заболевания, почти $60 \%$ пациентов имеют неспецифические симптомы. В статье приведен редкий клинический случай бифазной легочной бластомы у ребенка, находившегося на обследовании и лечении в КНП «Ивано-Франковская областная детская клиническая больница Ивано-Франковского областного совета». Отмечены основные клинические проявления, диагностика и направления лечения бифазной бластомы легких у ребенка на основании наблюдения за девочкой 5-летнего возраста, которая госпитализирована в стационар по поводу острой абдоминальной боли, боли в грудной клетке и кашля. После проведенных клинико-лабораторных и инструментальных методов обследования диагностирована правосторонняя пневмония, экссудативный плеврит. Комплекс проведенных лечебных мероприятий не дал ожидаемого положительного эффректа, улучшения состояния пациента. В связи с подозрением на новообразование грудной клетки ребенку назначено дополнительное исследование. Установлено, что лучшим методом верификации диагноза легочной бластомы является мультиспиральная компьютерная томография с внутривенным болюсным контрастированием и иммуногистохимическое исследование биоптата. Указаны методы 
лечения, использованные в данном случае, в частности, проведение противовоспалительной и полихимиотерапии по схеме, использование радикального метода лечения в Национальном институте рака г. Киев - оперативное вмешательство пневмонэктомии справа с резекцией перикарда. Ребенок в настоящее время находится на стадии устойчивой ремиссии на протяжении 4,5 лет. Описанный клинический случай демонстрирует трудность диагностики бластомы легких у детей из-за отсутствия типичных клинических проявлений.

Исследование выполнено в соответствии с принципами Хельсинкской декларации. На проведение исследований получено информированное согласие родителей детей.

Авторы заявляют об отсутствии конфрликта интересов.

Ключевые слова: дети, пневмония, бластома, пульмонология, диагностика, лечение.

У цей час проблема діагностики легеневої бластоми в дітей є дуже актуальною, оскільки зазначена патологія часто маскується під інші нозології, зокрема пневмонії, і діагностується вкрай важко. Легенева бластома - доволі рідкісне злоякісне новоутворення легень, що становить 0,25-0,5\% усіх первинних пухлин легень і має три підтипи: плевролегенева бластома, добре диференційована аденокарцинома плода та двофазна плевролегенева бластома. Зазвичай ця пухлина має двофазну гістологію, складається 3 незрілого епітелію і/або мезенхімальної тканини. Два компоненти тканини походять з одних і тих самих клітин-попередників [7,9]. Дорослий тип можна гістологічно поділити на двофазну та монофазну легеневу бластому. Двофазна легенева бластома містить оригінальні злоякісні епітеліальні клітини та оригінальні мезенхімальні тканини. Монофазна легенева бластома, яку ще називають епітеліальною або добре диференційованою аденокарциномою, містить лише злоякісні епітеліальні компоненти. Дитяча плевропульмональна бластома - це монофазна легенева бластома, що містить тільки оригінальну мезенхімальну тканину [5]. Однак рак легень, який спостерігається в дорослих, рідко зустрічається в дітей; хоча трапляється і тяжко диференціюється. Найпоширенішою первинною злоякісною пухлиною легень у дітей є плевролегеневі бластоми (57,1\%) [3]. Наразі немає специфічних діагностичних критеріїв цього діагнозу. Приблизно 60\% хворих відмічають неспецифічні симптоми [8]. Спільні клінічні характеристики в пацієнтів, які мали вказаний діагноз та описані в літературних джерелах, є неспецифічними та включали: кашель, втому, кров у мокротинні, стиснення та біль у грудях, задишку, втрату ваги в анамнезі [2,5,7], які повільно прогресували та часто ставали причиною встановлення хибних діагнозів. Під час рентгенологічного дослідження грудної клітки зазвичай виявляється аномальна тінь у легеневому полі, затемнення, ознаки пневмотораксу [7]. Остаточний діагноз плевролегеневої бластоми встановлюється за допомогою цитогенетичного аналізу пухлинних клітин після хірургічної резекції. Використання передопераційного патогістологічного дослідження для діагностики за допомогою таких методів, як бронхоскопія, тонкоголкова аспірація, біопсія пухлини під контролем комп'ютерної томографії (КТ) та інші методи, є недостатнім [8]. Враховуючи невелику кількість випадків і нещодавню перекласифікацію, інтерпретувати опубліковану епідеміологію та клінічні особливості цього захворювання складно [9]. Хворим, яким помилково виставлено попередній діагноз пневмонії, через брак чітких критеріїв цього новоутворення часто проводилася двотижнева протизапальна терапія, стан після якої не поліпшувався [7]. Адже основним методом лікування плевролегеневої бластоми після верифікації діагнозу є хірургічна резекція шляхом лобектомії або пневмонектомії [8]. Крім того, описано дані щодо використання променевої та хіміотерапії, але їх ефективність залишається невідомою через невелику кількість випадків цього захворювання, тому поки що консенсусу не досягнуто [7]. Системну хіміотерапію (переважно цисплатин) доцільно розглядати як ад'ювантну або метастазну та слід застосовувати в пацієнтів з олігометастатичним захворюванням, що піддається променевій терапії [4]. Важливим є своєчасне лікування не тільки для кращого виживання хворих, але й для уникнення ускладнень, таких як внутрішньопухлинна кровотеча. Хоча роль допоміжних засобів не до кінця вивчена, але може бути ключовим фактором довготривалого виживання [1].

\section{Клінічний випадок}

Під нашим спостереженням перебувала дитина віком 5 років. Дівчинку госпіталізовано до хірургічного відділення Івано-Франківської обласної дитячої клінічної лікарні з приводу гострого абдомінального болю, болю в грудній клітці, проте хірургічну патологію не підтверджено. Після проведеного рентгенологічного обстеження органів грудної клітки (ОГК) діагностовано правобічну пневмонію, ексудативний плеврит, після чого дитину переведено до пульмонологічного відділення цього ж лікувального закладу. Захворювання почалося з ознак гострої респіраторної інфекції: субфебрильної температури, нечастого кашлю малопродуктивного 
характеру, згодом приєднався біль у животі та грудній клітці. Зі слів матері, дівчинка хворіє впродовж 3 діб. Анамнез життя: дитина від третьої доношеної вагітності, третіх фізіологічних пологів. Росте і розвивається відповідно до віку. Спадковий анамнез не обтяжений. Перенесені захворювання - гостра респіраторна вірусна інфекція. Тубконтакт мати заперечує.

Об'єктивний статус: загальний стан дівчинки середньої тяжкості. Кашель рідко, малопродуктивний. Шкірні покриви блідо-рожеві, чисті. Видимі слизові оболонки рожеві, чисті. Язик вологий, не обкладений. Носове дихання вільне. Ознак дихальної недостатності на момент госпіталізації не виявлено. Периферичні лімфовузли не збільшені. Дихання ритмічне, з частотою 20 дихальних рухів на хвилину. Над легенями перкуторно - укорочення перкуторного звуку в нижніх відділах справа, зліва - ясний легеневий звук. При аускультації - дихання жорстке, ослаблене справа в нижніх відділах, хрипи не вислуховуються. Границі серця - у межах вікової норми. Тони серця при аускультації звучні, ритмічні, додаткові шуми не вислуховуються. Частота серцевих скорочень - 104 на хвилину. Живіт на момент госпіталізації до пульмонологічного відділення м'який, не болючий при пальпації, відрізки кишечника без особливостей. Печінка виступає на 1 см з-під краю реберної дуги. Селезінка не пальпується. Фізіологічні відправлення не порушені.

Дослідження виконано відповідно до принципів Гельсінської декларації. На проведення досліджень отримано інформовану згоду батьків дитини.

За період перебування в пульмонологічному відділенні проведено такі обстеження: загальний аналіз крові (гемоглобін - 132 г/л; еритроцити - 4,4×10 $12 / л$, лейкоцити -

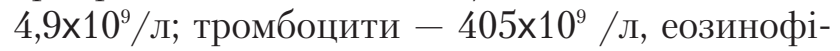
ли - 3\%; паличкоядерні нейтрофіли -

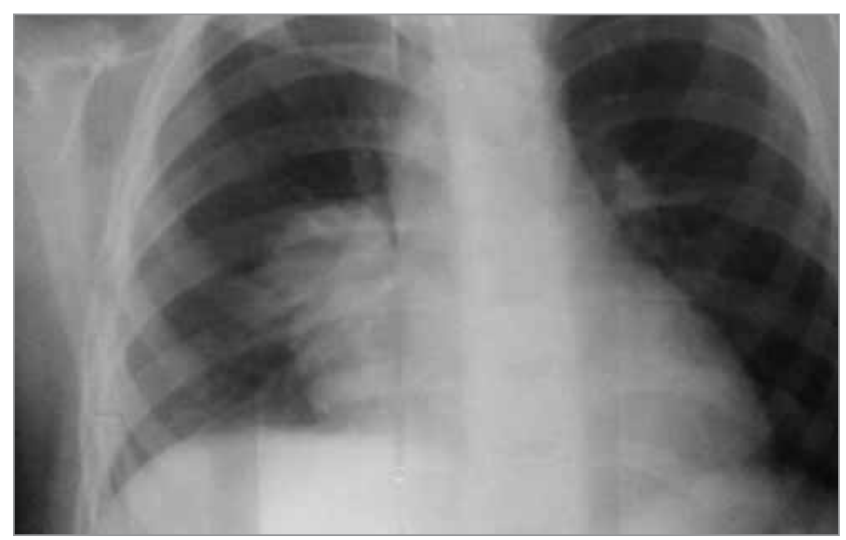

Рис. 1. Рентгенограма органів грудної клітки в прямій проєкції
17\%; сегментоядерні нейтрофіли - 44\%; лімфоцити $-33 \%$; моноцити - 3\%; швидкість осідання еритроцитів (ШОЕ) - 14 мм/год), біохімічний аналіз крові (загальний білок - 69,5 г/л, глюкоза - 4,8 ммоль/л, креатинін 57 мкмоль/л, сечовина - 2,4 ммоль/л, білірубін загальний - 16,99 мкмоль/л, прямий 4,87 мкмоль/л, непрямий - 12,12 мкмоль/л, калій - 4,10 ммоль/л, натрій - 132,7 ммоль/л, хлориди - 91,9 ммоль/л, аланінамінотрансфераза - 0,35 мкмоль/л, аспартатамінотрансфераза - 0,21 мкмоль/л, С-реактивний білок 6,2 мг/л (норма - до 5,0), прокальцитонін 0,07 нг/мл, лактатдегідрогеназа - 267 од/л), загальний аналіз сечі, загальна імунограма, коагулограма - у межах норми.

Рентгенографія ОГК: у нижніх відділах правої легені - гомогенне затемнення з нечітким верхнім контуром. Правий корінь розширений, не структурний. Правий купол діафрагми та синус не диференціюються. Простежується паракостальна смужка затемнення справа. Границі серця - у межах норми. Висновки рентгенкартина характерна при правобічній крупозній пневмонії в нижній долі, паракостально - наддіафрагмальний плеврит справа (рис. 1).

За даними ультразвукового дослідження органів черевної порожнини (УЗД ОЧП): печінка розташована типово, на 1 см виступає 3-під краю реберної дуги. Паренхіма звичайної ехогенності, печінкові вени - без особливостей, жовчні ходи ущільнені. Жовчний міхур спазмований, із перегином у тілі. Стінка ущільнена, нерівномірно потовщена. Вміст - неоднорідний осад. Підшлункова залоза візується на всьому протязі, не потовщена, структура однорідна, ехогенність дифузно підвищена. Селезінка не збільшена, структурно однорідна. Нирки розміщені типово, контури нирок рівні. Диференціація коркового й мозкового шарів збережена. Ехогенність паренхіми нирок звичайна. Серединний комплекс не поширений, не ущільнений. Порожниста система не поширена. Сечовий міхур $-20 \mathrm{~cm}^{3}$, осад.

За даними УЗД плевральних синусів: у правій плевральній порожнині - вільна рідина 35 мм, ліва плевральна порожнина - без особливостей.

На УЗД серця патологічних змін не виявлено.

За даними електрокардіографії: ритм синусовий, із частотою $98-106 /$ хв, синдром ранньої реполяризації шлуночків, підвищення вольтажу в лівих грудних відведеннях. 
Дитина консультована фтизіатром, діагноз «Пневмонія негоспітальна правобічна, ускладнена правобічним ексудативним плевритом. Первинний туберкульозний комплекс? Новоутворення грудної клітки справа?».

Комплекс лікувальних заходів: довенне введення фізіологічного розчину, сульцефу, еуропенему, метронідазолу, муколвану, дексону, реамберину, перорально ібупрофен, пробіотики. Проте лікування виявилося неефективним (з'явилася задишка, посилився кашель, утримувався помірний больовий синдром у грудній клітці, наростали прояви інтоксикаційного синдрому, гіпертермія, кількість плеврального випоту, не було позитивної рентгенологічної динаміки).

Загальноклінічний аналіз крові в динаміці (через 10 діб): нормалізація рівня нейтрофілів, лімфоцитоз, наростання ШОЕ: гемоглобін - 122 г/л, еритроцити - 4,37×1012/л, лей-

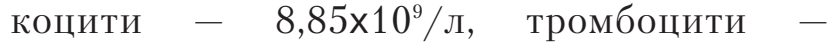
$344 \times 10^{9} / л$, еозинофіли - 1\%, паличкоядерні нейтрофіли $-4 \%$, сегментоядерні нейтрофіли $29 \%$, лімфоцити - 60\%, моноцити $5 \%$, плазматичні клітини - 1\%, ШОЕ 28 мм/год. Біохімічний аналіз крові в динаміці - без патологічних змін.

За даними УЗД плевральних порожнин (через 10 діб): у правій плевральній порожнині вільна рідина до середньої третини лопатки (6,2 см), ліва плевральна порожнина - без особливостей. Враховуючи погіршення стану дитини та відсутність позитивної динаміки після антибактеріальної терапії, дитину скеровано на мультиспіральну КТ (МСКТ). із внутрішньовенним болюсним контрастуванням Ультравіст 370-45 мл (МСКТ). За результатами МСКТ ОГК: у грудній порожнині справа в передньонижніх відділах парамедіастинально (перикардіально-паракостально) - додаткове утворення овальної форми з чіткими, дещо нерівними контурами, неоднорідною структурою, інтенсивним негомогенним контрастуванням, розмірами 7,0×5,0×7,0 см. Це утворення деформує праві відділи серця, верхню порожнисту вену, просвіт на даному рівні дещо звужений, у вищерозташованих відділах - розширений до 3,0 см без ознак інвазії. Дещо деформовані, зі зміщенням дорсальні прилягаючі легеневі судини, бронхи (середньої долі). Плевральні синуси вільні. У середостінні, у тому числі в ділянці коренів правої легені, множинні лімфовузли (довгою віссю до 1,1 см, короткою - до 0,8 см). Деструкцій у кістках немає. Висновок - «Об'ємний процес

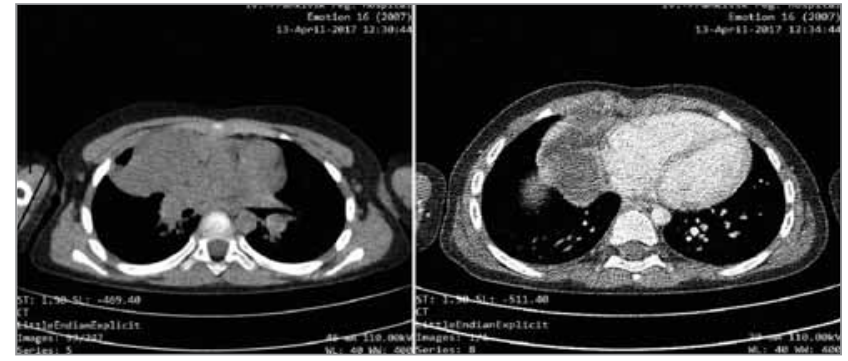

Pис. 2, МСКТ-скани органів грудної клітки з внутрішньовенним болюсним контрастуванням (аксіальні зрізи). Об'ємне утворення гемітораксу. Гістологічно: Біфазна легенева бластома

правого гемітораксу. Незначна внутрішньогрудна лімфаденопатія» (рис. 2).

За даними МСКТ ОГП і малого тазу з внутрішньовенним підсиленням (томогексол 350-50 мл): печінка дещо збільшена (краніокаудальний розмір - 138 мм), контури чіткі, рівні, структура однорідна, рівномірно накопичує контраст. Жовчний міхур із гомогенним вмістом. Селезінка з чіткими контурами, структурна, однорідна, розмірами 30×87 мм. Підшлункова залоза розмірами: головка -22 мм, тіло -19 мм, хвіст - 14 мм, протока не розширена. Нирки розміщені типово, співвідношення структур збережене. Збільшення заочеревинних лімфовузлів не виявлено. Сечовий міхур при цьому наповненні 3 чіткими рівними контурами. Об'ємних утворів у порожнині малого тазу не виявлено. Збільшення пахових лімфовузлів не виявлено. Деструктивних змін у кістках на обстеженому протязі не виявлено. Висновок МСКТ - ознак продовження основного захворювання не виявлено. Для подальшого дообстеження і верифікації діагнозу дитину скеровано до Національного інституту раку (НIP), м. Київ, де проведено пункційну біопсію легень. Цитологічний висновок - клітини, наявні в мазку, цитологічно схожі на клітини нейробластоми; для підтвердження діагнозу необхідне імуногістохімічне дослідження матеріалу.

За результатами імуногістохімічного дослідження: біфазна легенева бластома. Враховуючи скарги, анамнез захворювання, об'єктивні дані та результати додаткових методів дослідження, дитині встановлено діагноз «Біфазна легенева бластома правого гемітораксу. Стадія III pT4N0M0. Клінічна група II. Прийнято рішення щодо радикального лікування в умовах НIP. Проведено оперативне втручання за 2,5 міс від початку звернення пацієнта по медичну допомогу - правобічну пневмонектомію з резекцією перикарда. Для подальшого лікування дитину скеровано за місцем проживання. Дівчинка отримала 9 курсів поліхіміотерапії за схемою «CEVAIA» (вінкристин, іфос- 
фамід, актиноміцин, карбоплатин, епірубіцин, етопозид).

Після оперативного лікування та поліхіміотерапії впродовж 4,5 років дитині проведено в динаміці контрольну МСКТ ОГК та ОГП. Результати останньої МСКТ ОГК та ОГП: стан після правобічної пульмонектомії; ліва легеня розправлена, пневматизація та васкуляризація легеневої паренхіми не змінені; вогнищевих змін печінки, черевної та заочеревинної лімфаденопатії не виявлено; вузликових та інтерстиційних змін у паренхімі лівої легені не виявлено; воронкоподібна деформація грудної клітки, асиметрична, білыше справа.

У цей час дитина перебуває під спостереженням дитячого онколога та пульмонолога. Стан стійкої ремісії.

\section{Висновки}

Питання вчасної діагностики та диференційної діагностики плевролегеневої бластоми в дітей досі залишаються актуальними, недостатньо вивченими і потребують подальших досліджень. Діагностика плевролегеневої бластоми в дітей на цьому етапі ускладнена через недостатню патогномонічну клінічну симптоматику, відсутність чітких критеріїв і специфічних ознак, тому зазначена патологія може маскуватися під інші захворювання ОГП, зокрема пневмонію. Доволі інформативним методом діагностики залишається МСКТ із контрастуванням, гістологічне дослідження біоптату новоутворення. Через те, що зазначена пухлина рідко зустрічається в дитячому віці, не існує чітко розроблених стандартних рекомендацій щодо лікування, часто проводиться неадекватна терапія, що не має потрібного лікувального ефекту та не поліпшує стану пацієнта. За даними літератури [1,4] й результатами нашого спостереження, основним методом лікування плевролегеневої бластоми є хірургічна резекція шляхом лобектомії або пневмонектомії 3 післяопераційною поліхіміотерапією.

Автори заявляють про відсутність конфлікmу інтересів.

\section{REFERENCES/ЛITEPATУPA}

1. Carrasco R, Blanco M, Otero D et al. (2021). Classic biphasic pulmonary blastoma: importance of early treatment - a case report. Current Challenges in Thoracic Surgery. 3: 19. URL: https://doi.org/10.21037/ccts-20-77.

2. Jain TK, Singh H, Kumar R et al. (2020). Real Time F-18 FDG PET-CTGuided Metabolic Biopsy Targeting Differential FDG Avidity in a Pulmonary Blastoma. Nuclear Medicine and Molecular Imaging. 54 (5): 261-263. URL: https://doi.org/10.1007/s13139-020-00655-6.

3. Leckey BD, Carney JM, Sun JM et al. (2019). Novel intronic DICER1 variation associated with pleuropulmonary blastoma in two siblings. BMJ Case Reports. 12 (1): e227391. URL: https://doi.org/10.1136/bcr-2018-227391.

4. Lewis JA, Petty WJ, Urbanic J et al. (2018). Cure of Oligometastatic Classic Biphasic Pulmonary Blastoma Using Aggressive Tri-modality Treatment: Case Series and Review of the Literature. Cureus. 10: 11. URL: https://doi.org/10.7759/cureus.3586.

5. Liu Y, Luo D, Du T et al. (2017). Clinical and pathology analysis of 1 case of adult pleural pulmonary blastoma. Medicine.

96 (50): e8918. URL: https://doi.org/10.1097/
md. 0000000000008918 .

6. Luo Z, Cao C, Xu N et al. (2020). Classic biphasic pulmonary blastoma: a case report and review of the literature. Journal of International Medical Research. 48 (10): $030006052096239 . \quad$ URL: https://doi.org/10.1177/0300060520962394.

7. Maojiang Y, Bing L, Zhang $C$ et al. (2019). Classical biphasic pulmonary blastoma in a young woman: case report and review of literature. Int $\mathrm{J}$ Clin Exp Pathol. 12 (12): 4040-4400.

8. Nemeh F, Kuo A, Ross J et al. (2017). The Radiologic and Pathologic Diagnosis of Biphasic Pulmonary Blastoma. Journal of Radiology Case Reports. 11: 9. URL: https://doi.org/10.3941/jrcr.v11i9.3153.

9. Smyth RJ, Fabre A, Dodd JD et al. (2014). Pulmonary blastoma: a case report and review of the literature. BMC Research Notes. 7: 1. URL: https://doi.org/10.1186/1756-0500-7-294.

10. Van Loo S, Boeykens E, Stappaerts I et al. (2011). Classic biphasic pulmonary blastoma: A case report and review of the literature. Lung Cancer. 73 (2): 127-132. URL: https://doi.org/10.1016/j.lungcan.2011.03.018.

\section{Відомості про авторів:}

Дутчук Оксана Василівна - асистент каф. педіатрії Івано-Франківського НМУ. Адреса: м. Івано-Франківськ, вул. Коновальця, 132. https://orsid.org/0000-0003-1160-4099. Кочерга Зоряна Ростиславівна - д.мед.Н., проф., зав. каф. пропедевтики педіатрії Івано-Франківського НМУ.

Адреса: м. Івано-Франківськ вул. Чорновола, 44. https://orsid.org/0000-0003-0964-8463.

Волошинович Вікторія Мирославівна - к.мед.н., доц. каф. педіатрії Івано-Франківського НМУ. Адреса: м. Івано-Франківськ, вул. Коновальця, 132. https://orcid.org/0000-0002-7326-8513.

Алексеєва Юля Іванівна - к.мед.н., доц. каф. педіатрії Івано-Франківського НМУ. Адреса: м. Івано-Франківськ, вул. Коновальця, 132. https://orsid.org/0000-0002-6279-9992. Томащук Юрій Степанович - лікар-онколог дитячий, відділення онкогематології КНП «Івано-Франківська ОДКЛ ІФ ОР». Адреса: м. Івано-Франківськ, вул. Коновальця, 132. https://orsid.org/0000-0002-7124-5027.

Стаття надійшла до редакції 13.08.2021 р., прийнята до друку 09.11.2021 p. 


\title{
Клінічний випадок мультисистемного запального синдрому, асоційованого із SARS-CoV-2
}

\author{
КНП Київської обласної ради «Київська обласна дитяча лікарня № 2», м. Біла Церква, Україна
}

Modern Pediatrics. Ukraine. (2021). 7(119): 51-54. doi 10.15574/SP.2021.119.51

For citation: Pohorila YeYe. (2021). Clinical case of SARS-CoV-2-associated multisystem inflammatory syndrome. Modern Pediatrics. Ukraine. 7(119): 51-54. doi 10.15574/SP.2021.119.51.

Описано клінічний перебіг, особливості діагностичних обстежень та труднощі у верифікації нової нозології — мультисистемного запального синдрому, асоційованого із SARS-CoV-2, у дівчинки віком 15 років. Дівчинку доставлено до Київської обласної дитячої лікарні № 2 із скаргами на підвищення температури тіла, виражений інтоксикаційний синдром, загальну слабкість, запаморочення голови, відсутність сечі протягом доби. Дитину оглянуто консиліумом лікарів, обстежено лабораторно та інструментально, після ретельно зібраного епідеміологічного анамнезу виявлено можливий контакт із хворим на коронавірусну інфекцію за місцем навчання та встановлено ймовірний випадок мультисистемного запального синдрому, асоційованого 3 SARS-CoV-2.

За результатами власних спостережень під час пандемії, ця нозологія спостерігається у хворих, які перехворіли на коронавірусну інфекцію в клінічній або субклінічній формі та на період госпіталізації мали клінічний симптомокомплекс кавасакіподібних симптомів. Таке захворювання є новим на сьогодні, має різноманітні клінічні прояви та патологічні особливості, що є проблемою для клініцистів. Адже ще не існує уніфікованих протоколів діагностики та лікування MIS-C (мультисистемний запальний синдром), і кожний лікар опирається на власний досвід та описані раніше випадки.

Описаний випадок мультисистемного запального синдрому допоможе практикуючим клініцистам на ранніх етапах діагностувати хворобу і надати кваліфіковану допомогу пацієнтам.

Дослідження виконано відповідно до принципів Гельсінської декларації. На проведення досліджень отримано інформовану згоду батьків дитини Автор заявляє про відсутність конфлікту інтересів.

Ключові слова: мультисистемний запальний синдром, дівчинка віком 15 років, кавасакоподібні симптоми, SARS-CoV-2, внутрішньовенний імуноглобулін, ацетилсаліцилова кислота, глюкокортикостероїди.

\section{Clinical case of SARS-CoV-2-associated multisystem inflammatory syndrome \\ Ye.Ye. Pohorila \\ Kyiv Regional Children's Hospital No. 2, Bila Tserkva, Ukraine}

The clinical course, features of diagnostic examinations and difficulties in verification of the new nosology of multisystem inflammatory syndrome associated with SARS-CoV-2 in 15-year-old girls are described. The girl was taken to the Kyiv Regional Children's Hospital No. 2 with complaints of fever, intoxication syndrome, general weakness, dizziness, vertigo, lack of urine during the day. The child was examined by a consilium of doctors, examined in the laboratory and instrumentally, after a carefully collected epidemiological history revealed possible contact with a patient with coronavirus infection at the place of study and identified a probable case of multisystem inflammatory syndrome associated with SARS-CoV-2. According to the results of our own observations during the pandemic, this nosology was found in patients who relapsed into coronavirus infection in clinical or subclinical form and for the period of hospitalization had a clinical symptom complex of Kawasaki with similar symptoms. This disease is new today, has a variety of clinical manifestations and pathologica features that are a problem for clinicians. After all, at present there are no unified protocols for the diagnosis and treatment of MIS-C (multisystem inflammatory syndrome) and each doctor relies on their own experience and previously described cases. This case of multisystem inflammatory syndrome will help practicing clinicians in the early stages to diagnose the disease and provide qualified care to patients.

The research was carried out in accordance with the principles of the Helsinki declaration. The study protocol was approved by the Local ethics committee of all participating institution. The informed consent of the patient was obtained for conducting the studies.

No conflict of interest was declared by the author.

Key words: multisystem used for setting fire syndrome, 15-year-old girl, kawasaky-like symptoms, SARS-CoV-2, intravenous immunoprotein, acetophene, glucocorticosteroids.

\section{Клинический случай мультисистемного воспалительного синдрома, ассоциированного с SARS-CoV-2}

Е.Е. Погорелая

КНП Киевского областного совета «Киевская обласная детская больница № 2», г. Белая Церковь, Украина

Описаны клиническое течение, особенности диагностических обследований и трудности верификации новой нозологии - мультисистемного воспалительного синдрома, ассоциированного с SARS-CoV-2, у девочки в возрасте 15 лет. Девочка доставлена в Киевскую областную детскую больницу № 2 с жалобами на повышение температуры тела, выраженный интоксикационный синдром, общую слабость, головокружение, отсутствие мочи в течение суток.

Ребенок осмотрен консилиумом врачей, обследован лабораторно и инструментально, после тщательно собранного эпидемиологического анамнеза выявлен возможный контакт с больным коронавирусной инфекцией по месту обучения и установлен вероятный случай мультисистемного воспалительного синдрома, ассоциированного с SARS-CoV-2.

По результатам собственных наблюдений, во время пандемии данная нозология встречается у больных, переболевших коронавирусной инфекцией в клинической или субклинической форме и на период госпитализации имевших клинический симптомокомплекс кавасакиподобных симптомов Данное заболевание новое на сегодняшний день, имеет разнообразные клинические проявления и патологические особенности, что является проблемой для клиницистов. Ведь на данный момент нет унифицированных протоколов диагностики и лечения MIS-C (мультисистемный воспалительный синдром) и каждый врач опирается на собственный опыт и описанные ранее случаи.

Представленный случай мультисистемного воспалительного синдрома поможет практикующим клиницистам на ранних этапах диагностировать болезнь и предоставить квалисрицированную помощь пациентам.

Исследование выполнено в соответствии с принципами Хельсинкской декларации. На проведение исследований получено информированное согласие родителей ребенка.

Автор заявляет об отсутствии конфликта интересов.

Ключевые слова: мультисистемный воспалительный синдром, девочка 15 лет, кавасакоподобные симптомы, SARS-CoV-2, внутривенный иммуноглобулин, ацетилсалициловая кислота, глюкокортикостероиды. 


\section{Вступ}

$\prod_{\mathrm{p}}^{\mathrm{a}}$ андемія інфекції, викликана коранавірусом SARS-CoV-2, - одне з найгостріших питань медицини XXI ст., хвороба, яка уражує як доросле, так і дитяче населення, та має різні «маски» перебігу. Якщо на початку пандемії вірус уражував здебільшого доросле населення, то на сьогодні в дітей все частіше реєструють позитивний тест на коронавірус COVID-19. Гостро постає питання постковідних станів. Під час перегляду клінічних випадків COVID-19 у дітей клініцисти виявили хвилю симптомів, які клінічно нагадували хворобу Кавасакі. У липні 2020 року в Україні у м. Львові зареєстровано перший випадок захворювання з гарячкою і респіраторними симптомами, що нагадували хворобу Кавасакі з високим титром антитіл імуноглобуліну $\mathrm{G}$ до коронавірусної інфекції. Надалі отримано нову інформацію про схожі випадки і оголошено про появу нового незвичного розладу - педіатричного мультисистемного запального синдрому. Особливості клінічного перебігу, діагностики й лікування цього захворювання наведено на клінічному прикладі дівчинки віком 15 років.

Дослідження виконано відповідно до принципів Гельсінської декларації. На проведення досліджень отримано інформовану згоду батьків дитини.

\section{Клінічний випадок}

Дівчинка М., 15 років, переведена з Таращанської центральної районної лікарні з діагнозом «Інтоксикаційний синдром невідомого генезу, гостра ниркова недостатність, анурія, токсико-ексикоз 3-го ст.» до Київської обласної дитячої лікарні № 2 у супроводі лікаря екстреної медичної допомоги зі скаргами на підвищення температури тіла до $38,8^{\circ} \mathrm{C}$, загальну слабкість, блідість шкірних покривів, запаморочення, відсутність сечі протягом доби. 3 анамнезу захворювання відомо, що дівчинка захворіла гостро, зранку, коли поскаржилася на біль у животі, з'явилося блювання, яка повторювалося 8 разів на добу, підвищилася температура тіла до $38,8^{\circ}$ С. Дитину доставлено каретою екстреної медичної допомоги до Київської обласної дитячої лікарні № 2.

Дитину оглянуто консиліумом лікарів. Об'єктивно стан дитини тяжкий, обумовлений загальною слабкістю, блідістю шкірних покривів, гіпертермією, тахікардією, тахіпное, гіпотензією (артеріальний тиск $-80 / 40$ ), відсутністю сечі. Температура тіла $-38,2^{\circ} \mathrm{C}$, частота серцевих скорочень - 110 ударів на хвилину, частота дихання -28 на хвилину, сатурація - 96\%. Дитина у свідомості, але загальмована. На запитання відповідає із затримкою. Правильної тілобудови. Задовільного харчування. Зі слів дівчинки, протягом доби утримувалася плямисто-папульозна висипка яскраво-рожевого кольору переважно в ділянці стегон. Ознаки склериту. Слизова ротової порожнини яскраво-рожевого кольору, «полуничний» язик (рис. 1). За декілька днів з'явилося лущення в ділянці дистальних фаланг пальців верхніх кінцівок (рис. 2). Периферичні лімфатичні вузли по типу полімікроаденії. Дихання через ніс вільне. Перкуторні межі серця не розширені. Тони серця дещо послаблені, ритм правильний, виражена тахікардія, систолічний шум над верхівкою. Над легенями - жорстке дихання, хрипи не вислуховуються. Живіт при пальпації м'який, чутливий по ходу кишечника. Випорожнення оформлені, сечовипускання самостійного немає, через сечовий катетер отримано 200 мл сечі. Після детально зібраного анамнезу встановлено відсутність задокументованого випадку коронавірусної інфекції та виявлено епідеміологічний зв'язок з інфекцією SARS-CoV-2 за місцем навчання. Тому встановлено ймовірний випадок мультисистемного запального синдрому, асоційованого із SARS-CoV-2.

За даними лабораторних обстежень: у загальному аналізі крові показники лейкоци тів становили $12,95-23,19 \times 10^{9} \pi \quad\left(12,95-23,19 \times 10^{9} / л\right)$, швидкість осідання еритроцитів (ШОЕ) 16-40 мм/год, паличкоядерні - від 10-44\%, підвищення показника тромбоцитів - до 525,7 Г/л. У біохімічному аналізі крові виявлено підвищення активності печінкових ферментів (аланінамінотрансфераза - до 164,1 од./л, аспартатамінотрансфераза - 123 од./л), показників азотистого обміну (креатинін 73,27 ммоль/л, сечовина крові - 5,17 ммоль/л), гострофазових показників запалення (прокальцитонін - 21,3 нг/мл, С-реактивний білок 160,94 мг/л, феритин - 85,3 мкг/л), а також зниження рівня альбуміну $-26,8$. У коагулограмі відмічено показники Д-димера в межах 0,42-3,08 нг/л, протромбіновий час 16,5 с, активований частковий тромбопластиновий час $-20-45,1$ c, фібриноген $-2-4,3$ г/л. Проведено тестування полімеразної ланцюгової реакції (ПЛР) до коронавірусу - результат негативний, визначено титр антитіл імуноглобуліну G до SARS-CoV-2 - підвищений титр 


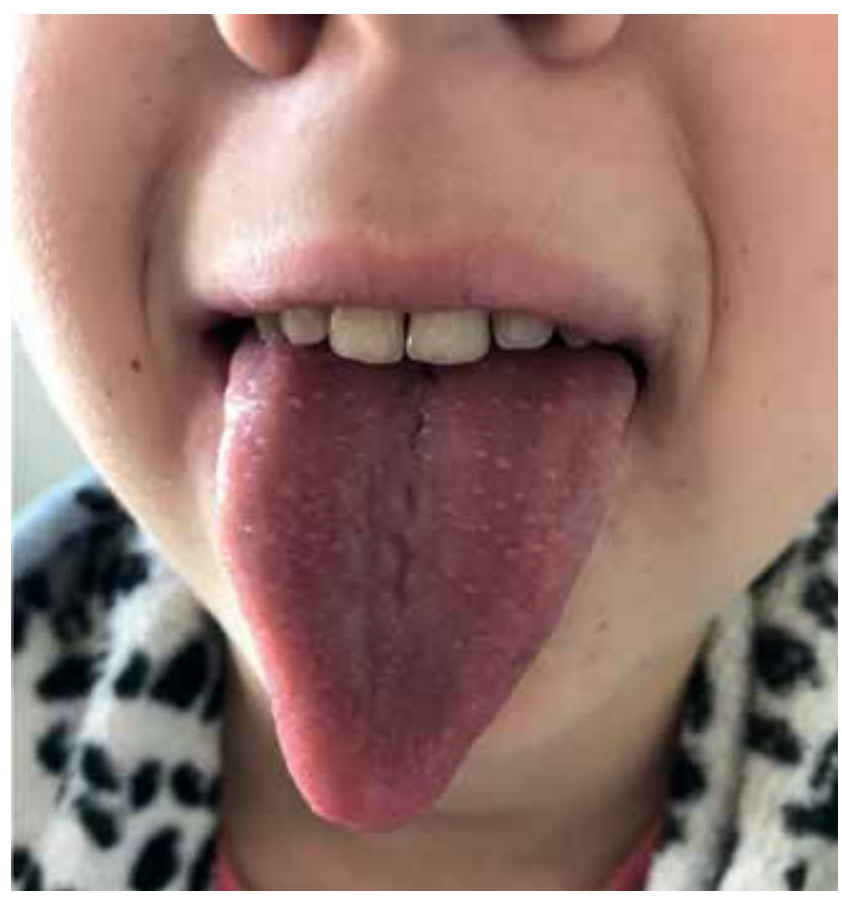

Pис. 1. «Полуничний» язик

антитіл $(6,179)$. Загальний аналіз сечі: без патологічних змін. Бактеріологічне дослідження крові на стерильність: посів стерильний. Ультразвукове дослідження органів черевної порожнини: реактивні зміни печінки, жовчного міхура, нефропатія. Електрокардіографія: синусова тахікардія, метаболічні зміни міокарда. Рентгенографія органів грудної клітки: значно підсилений легеневий малюнок, корені розширені, ущільнені. Серцева тінь звичайна, синуси вільні. За 2 тижні від початку захворювання й лікування проведено ехокардіографію з візуалізацією коронарних судин і виявлено пролапс передньої стулки мітрального клапана 1-го ст. із незначною мітральною регургітацією. Коронарні артерії - без патологічних змін (рис. 3)

Враховуючи дані анамнезу захворювання (гострий початок, наявність гастроінтестинальних розладів, епідеміологічний зв'язок з інфекцією SARS-CoV-2 за місцем навчання), дані об'єктивного обстеження (наявність кавасакоподібних симптомів [1]: фебрильна гарячка, плямисто-папульозна висипка на шкірі в ділянці стегон, ознаки склериту, «полуничний» язик, згодом лущення в ділянці дистальних фаланг обох кистей), дані лабораторних показників (збільшення рівня С-реактивного білка, прокальцитоніну, Д-димера, креатиніну, аланінамінотрансферази і аспартатамінотрансферази, негативний ПЛР-тест до коронавірусної інфекції, підвищений титр антитіл імуноглобуліну $\mathrm{G}$

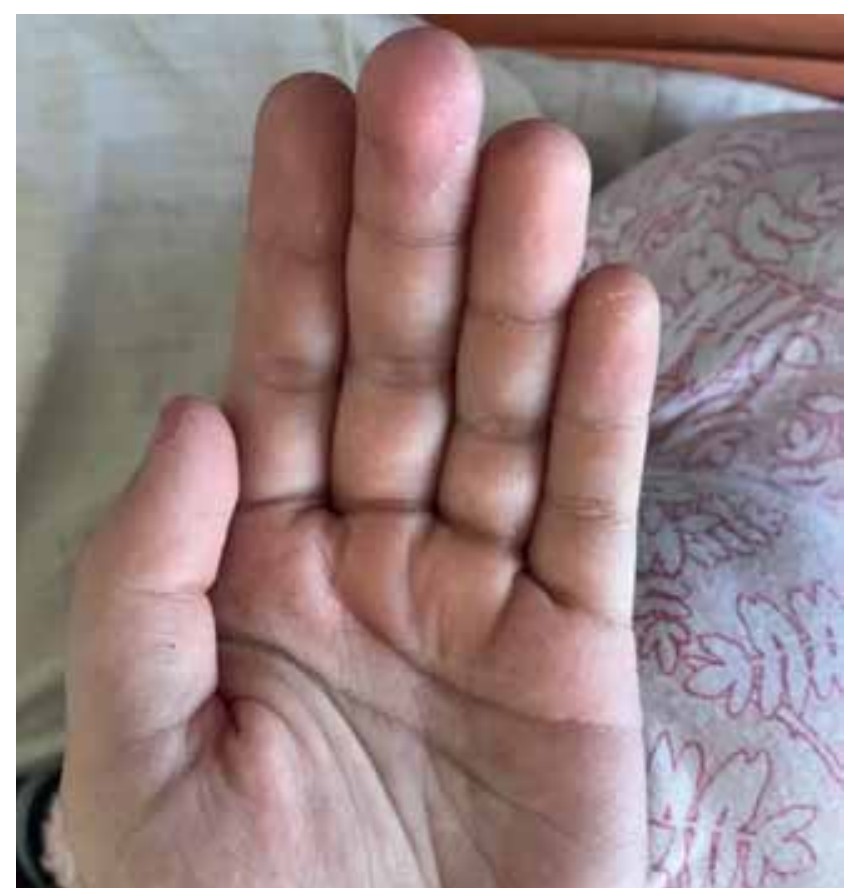

Pис. 2. Лущення в ділянці дистальних сраланг пальців верхніх кінцівок

до SARS-CoV-2) підтверджено діагноз «Педіатричний мультисистемний запальний синдром, асоційований із SARS-CoV-2».

Розпочато лікування в першу добу госпіталізації [2]:

1) режим ліжковий із поступовим розширенням;

2) кардіореспіраторний моніторинг до поліпшення стану;

3) внутрішньовенна дезінтоксикаційна терапія глюкозо-сольовими розчинами, реосорбілакту;

4) антибіотикотерапія до остаточної верифікації діагнозу;

5) імуноглобулін внутрішньовенно в дозі 2 г/кг маси тіла протягом 2 діб;

6) ацетилсаліцилова кислота в дозі 5 мг/кг маси тіла в 3 застосування;

7) глюкокортикостероїди 3 розрахунку 1 мг/кг маси тіла;

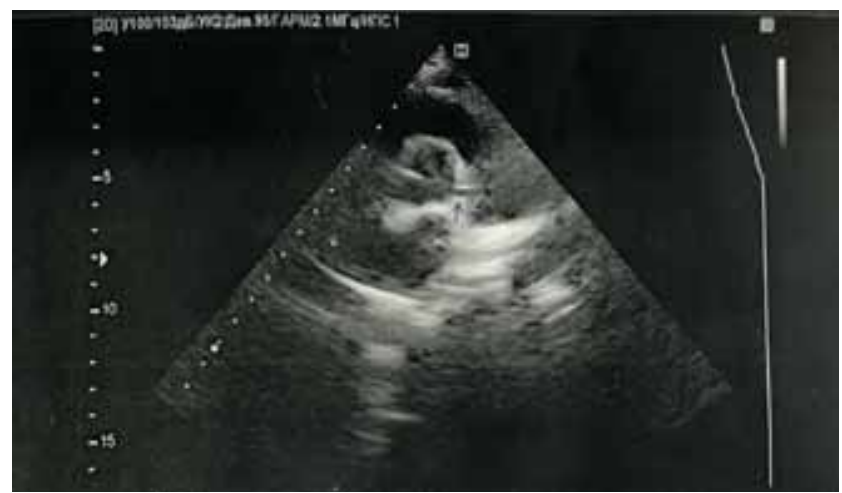

Pис. 3. Ехокардіографрія з візуалізацією коронарних судин 
8) супровідна терапія - аспаркам, гастропротектори.

На тлі розпочатої терапії відмічено позитивну динаміку перебігу захворювання (нормалізація температури тіла, зворотний розвиток клінічних симптомів, позитивна динаміка лабораторних показників до повної нормалізації).

Дитину виписано додому в задовільному стані на 25-ту добу госпіталізації. Рекомендовано:

1) спостереження кардіоревматолога дитячого;

2) уникнення переохолоджень, контакту з хворими на гостре респіраторне захворювання;

3) проведення повторної ехокардіографії з візуалізацією коронарних артерій у науково-практичному медичному центрі дитячої кардіології та кардіохірургії за 3-4 тижні з подальшим вирішенням терміну застосування й дозування аспірину;

4) забезпечення контролю в динаміці загального аналізу крові з підрахунком кількості тромбоцитів, коагулограма, загальний аналіз сечі 1 раз на тиждень;

5) зниження добової дози медролу по 2 мг 1 раз на 3 доби до повної відміни препарату;

6) застосовування аспірин кардіо 3 мг/кг/добу до 6-8 тижнів за відсутності змін коронарних судин;

7) супровідна терапія аспаркамом, езомепразолом;

8) планова госпіталізація з метою динамічного клінічного й лабораторного контролю через 3-4 тижні.

\section{Обговорення}

За результатами власних спостережень під час пандемії, ця нозологія зустрічалась у хворих, які перехворіли на коронавірусну інфекцію в клінічній або субклінічній формі та на період госпіталізації мали клінічний симптомокомплекс кавасакіподібних симптомів. Таке захворювання є новим на сьогодні, має різноманітні клінічні прояви та патологічні особливості, що становить проблему для клініцистів. Адже ще не існує уніфікованих протоколів діагностики й лікування MIS-C (мультисистемний запальний синдром), і кожний лікар опирається на власний досвід та описані раніше випадки.

Кожний випадок є унікальним і має різноманітну клінічну картину, але основні диференційні ознаки та алгоритм ведення пацієнтів із MIS-C, наведені в статті, можуть допомогти своєчасно діагностувати й розпочати лікування зазначеної патології, щоб домогтися повного одужання пацієнта без ускладнень унаслідок захворювання.

\section{Висновки}

Мультисистемний запальний синдром - це рідкісний синдром, при якому відбувається запалення різних органів і систем, у тому числі очей, шкіри та внутрішніх органів; стан, який потребує обов'язкової термінової госпіталізації дитини і вчасно розпочатого лікування для попередження розвитку змін у коронарних артеріях та розвитку коронарних аневризм. Опис кожного випадку зазначеного захворювання є надважливим для співпраці лікарів з метою успішної діагностики й лікування. Автор висловлює сподівання, що наведений у статті клінічний випадок MIS-C може допомогти клініцистам надавати високоспеціалізовану медичну допомогу пацієнтам.

Автор заявляе про відсутність конфлікту iнmepecis.

\section{References/Література}

1. Berezhnyi VV, Marushko TV, Marushko YuV. (2013). Klinichna revmatolohiia dytiachoho viku. Kyiv: 241. [Бережний BB, Марушко ТВ, Марушко ЮВ. (2013). Клінічна ревматологія дитячого віку. Друге видання. Київ: 241].

2. Oshlianska OA, Okhotnikova OM, Zakharchuk OV, Rusak SO. (2021). Multysystemnyi zapalnyi syndrom, asotsiiovanyi z infektsiieiu SARS-
COV-2, u ditei: nova khvoroba chy syndrom? (na prykladi klinichnoho vypadku). Ukrainskyi revmatolohichnyi zhurnal. 85: 3. [Ошлянська ОА, Охотнікова ОМ, Захарчук ОВ, Русак СО. (2021). Мультисистемний запальний синдром, асоційований з інфекцією SARS-COV-2, у дітей: нова хвороба чи синдром? (на прикладі клінічного випадку). Український ревматологічний журнал. 85: 3].

\section{Відомості про авторів:}

Погоріла Євдокія Євдокимівна - кардіоревматолог дитячий вищої категорії, зав. педіатричного відділення № 2 КНП КОР «Київська обласна дитяча лікарня № 2».

Адреса: м. Біла Церква, вул. Шолом-Алейхема, 46; тел. +38(04463) 5-36-74.

Стаття надійшла до редакції 03.08.2021 р., прийнята до друку 09.11.2021р. 


\title{
О.Б. Синоверська', Ю.І. Алексеєва', Н.М. Фоменко', М.Й. Рейтмаєр', С.Б. Шкандрій \\ Синдром подовженого інтервалу QT в педіатричній практиці: дані літератури та опис клінічного випадку
}

\author{
2КНП «Івано-Франківська обласна дитяча клінічна лікарня Івано-Франківської обласної ради», Україна
}

Modern Pediatrics. Ukraine. (2021). 7(119): 55-61. doi 10.15574/SP.2021.119.55

For citation: Synoverska OB, Alekseeva Yul, Fomenko NM, Reitmaier MY, Shkandrii SB. (2021). Prolonged QT interval syndrome in pediatric practice: literature data and clinical case description. Modern Pediatrics. Ukraine. 7(119): 55-61. doi 10.15574/SP.2021.119.55.

\begin{abstract}
Наведено основні відомості про синдром подовженого інтервалу QT, який являє собою рідкісну патологію серцево-судинної системи та може спричинити раптову смерть дитини. У патогенезі цього захворювання зазвичай лежать мутації в генах, що відповідають за порушення срункцій іонних каналів. Описано синдроми Джервелла і Ланге—Нільсена, Романо—Ворда, Андерсена—Тавіла та Тімоті, як основні спадкові варіанти такого синдрому. Наведено приклад власного спостереження захворювання в пацієнта, який перебував на обстеженні та лікуванні у КНП «Івано-Франківська обласна дитяча клінічна лікарня Івано-Франківської обласної ради». Основна увага зосереджена на гострому, атиповому початку захворювання, яке дебютувало з судомного синдрому та раптової серцевої смерті. Описано клінічну картину цього випадку, особливості перебігу, наведено показники основних методів дослідження. Висвітлено відомості стосовно лікування зазначеного клінічного випадку на місцевому рівні та у відділенні хірургічного лікування порушень ритму, де пацієнту виконано імплантацію ендокардіального двокамерного кардіовертера-дефібрилятора. Наведено дані щодо подальшого спостереження та лікування дитини за місцем проживання.
\end{abstract}

Дослідження виконано відповідно до принципів Гельсінської декларації. На проведення досліджень отримано інсормовану згоду батьків дитини. Автори заявляють про відсутність конфлікту інтересів.

ключев спова синдром, інтервал QT, етіологія, патогенез, клінічна картина, діагностика, обстеження, лікування.

\section{Prolonged QT interval syndrome in pediatric practice: literature data and clinical case description O.B. Synoverska', Yu.I. Alekseeva', N.M. Fomenko', M.Y. Reitmaier', S.B. Shkandrii \\ 'Ivano-Frankivsk National Medical University, Ukraine, \\ ${ }^{2}$ Municipal non-profit enterprise Ivano-Frankivsk RCCH IF RC, Ukraine}

The article provides basic information about the syndrome of prolonged QT interval, which is a rare pathology of the cardiovascular system and can cause sudden death. The mutations in the genes responsible for dysfunction of ion channels are the key in the pathogenesis of this disease. Jerwell and Lange-Nielsen, RomanoWard, Andersen—Tavil and Timothy syndromes are described as the main hereditary variants of this syndrome. A own case of the disease in a patient was given. The peculiarity of this case was on the acute, atypical onset of the disease, which started with convulsions and sudden cardiac death. The clinical picture of this case, features of a current are described, indicators of the basic methods of research are resulted. Information on the treatment of this clinical case at the local level and in the department of surgical treatment of arrhythmias, where the patient underwent implantation of endocardial bicameral cardioverter-defibrillator, is presented. Data on further observation and treatment of the child at the place of residence are given.

The research was carried out in accordance with the principles of the Helsinki declaration. The informed consent of the patient was obtained for conducting the studies. No conflict of interest was declared by the authors.

Key words: syndrome, QT interval, etiology, pathogenesis, clinical picture, diagnosis, examination, treatment.

\author{
Синдром удлиненного интервала QT в педиатрической практике: \\ данные литературы и описание клинического случая \\ О.Б. Синоверская', Ю.И. Алексеева', Н.Н. Фоменко', М.И. Рейтмаер', С.Б. Шкандрій² \\ 'Ивано-Франковский национальный медицинский университет, Украина \\ КНП «Ивано-Франковская областная детская клиническая больница Ивано-Франковского областного совета», Украина
}

Представлены основные сведения о синдроме удлиненного интервала QT, представляющем собой редкую патологию сердечно-сосудистой системы и может стать причиной внезапной смерти ребенка. В патогенезе данного заболевания обычно лежат мутации в генах, отвечающих за нарушение функций ионных каналов. Описаны синдромы Джервелла и Ланге-Нильсена, Романо-Уорда, Андерсена-Тавила и Тимоти как основные наследственные варианты данного синдрома. Приведен пример собственного наблюдения заболевания у пациента, находившегося на обследовании и лечении в КНП «Ивано-Франковская областная детская клиническая больница Ивано-Франковского областного совета». Основное внимание сосредоточено на остром, атипичном начале заболевания, дебютировавшего с судорожного синдрома и внезапной сердечной смерти. Описана клиническая картина данного случая, особенности течения, приведены показатели основных методов исследования. Представлены сведения о лечении клинического случая на местном уровне и в отделении хирургического лечения нарушений ритма, где пациенту выполнена имплантация эндокардиального двухкамерного кардиовертерадесрибриллятора. Приведены данные по дальнейшему наблюдению и лечению ребенка по месту жительства.

Исследование выполнено в соответствии с принципами Хельсинкской декларации. На проведение исследований получено инсоормированное согласие родителей детей.

Авторы заявляют об отсутствии конфликта интересов.

Ключевые слова: синдром, интервал QT, этиология, патогенез, клиническая картина, диагностика, обследование, лечение. 
Електрокардіографічний інтервал QT представляє фази деполяризації та реполяризації потенціалу дії серця. Тривалість потенціалу дії визначається взаємодією кількох іонних каналів. Подовження інтервалу QT у результаті зміни швидкості іонних токів (зменшення реполяризації зовнішніх калієвих струмів або збільшення деполяризаційних внутрішніх натрієвих або кальцієвих струмів) і збільшення тривалості потенціалу дії є патофізіологічним субстратом для синдрому подовженого інтервалу QT (Long QT syndrome, LQTS) [1,5,8,9].

Синдром подовженого інтервалу QT (LQTS) рідкісне захворювання, що являє собою кардіонейропатію та може спричинити раптову смерть у здорових людей. На сьогодні LQTS асоціюють із «первинною електричною хворобою серця» (primary electric heart disease), що не супроводжується органічними змінами або 3 вродженими структурними аномаліями серця $[6,10]$. В основі «електричної хвороби» лежать мутації в генах, що відповідають за порушення функцій іонних каналів. Визначають 180 мутацій, що локалізуються в 6 генах, розташованих переважно на трьох хромосомах 7, 11 i 3 [1,5,9].

Виділяють декілька спадкових варіантів цієї патології. Так, у 1964 р. уперше описали синдром Романо-Ворда (RW) - найпоширенішу форму захворювання з аутосомно-домінантним типом успадкування, яка характеризується подовженням інтервалу QT, рецидивними синкопальними станами внаслідок шлуночкової тахікардії типу «пірует» та має три типи $[6,9,10]$.

У 1957 р. описали клінічну картину синдрому Джервелла і Ланге-Нільсена (JLN), який успадковується за аутосомно-рецесивним типом, характеризується більш значним подовженням інтервалу QT, загрозливими для життя аритміями, поєднується з вродженою глухотою, обумовлюється мутаціями в генах KCNQ1 або KCNE2, що кодують головну і додаткову субодиниці потенціал-залежних калієвих каналів й призводять до зниження сили імпульсу $[4,6,9,10]$.

При синдромі Андерсена-Тавіла (Andersen-Tawil), що має аутосомно-домінантний тип успадкування, а у $50 \%$ усіх випадків обумовлений мутацією de novo, подовження інтервалу QT супроводжується появою хвилі $\mathrm{U}$, пароксизмами поліморфної шлуночкової піруетної тахікардії типу TdP (torsades de pointes); аномаліями розвитку кісткової системи (низький зріст, мікрогнатія, гіпертелоризм, низьке положення вушних раковин, сколіоз, клинодакти- лія); гіпокаліємією і періодичним калій-залежним паралічем $[6,9,10]$.

Рідкісною формою LQTS є синдром Тімоті. Такий варіант небезпечний високим ризиком раптової смерті. У пацієнтів із цим синдромом діагностують вроджені вади серця та порушення серцевої провідності (тимчасові і постійні форми атріовентрикулярної блокади); когнітивні порушення (затримка психомоторного розвитку, аутизм); гіпоглікемію; імунодефіцитні стани; аномалії обличчя (згладженість носогубної складки, низьке розташування вушних раковин тощо); частковою або повною синдактилією. Синдром Тімоті успадковується за аутосомно-домінантним типом, однак у більшості випадків визначається мутація de поvо $[4,6,10]$.

Набутий синдром LQTS може зумовлюватися застосуванням лікарських засобів. Так, подовження інтервалу може спричинятися застосуванням антиаритмічних засобів (хінідін, прокаїнамід, дизопірамід), антиеметичних, кардіологічних, психотропних, антибактеріальних (ципрофлоксацин, левофлоксацин), протипухлинних, протигрибкових (флуконазол), петлевих діуретиків (фуросемід). Факторами ризику виникнення LOTS є нудота та блювання, діарея, гіпокаліємія ( $\leq 3,5$ ммоль/л), гіпомагніємія ( $\leq 1,6$ мг/дл), гіпокальціємія ( $\leq 8,5$ мг/дл). Крім цього, останнім часом з'явилися праці, в яких виникнення набутого LQTS пов'язане з наявністю у хворих «німої» мутації в одному з генів, що відповідає за вроджений LQTS [2,3,9].

Мета дослідження - ознайомити лікарів із клінічними проявами LQTS як захворювання, що може загрожувати життю дитини, на прикладі власного клінічного досвіду.

Дослідження виконали відповідно до принципів Гельсінської декларації. На проведення досліджень отримали інформовану згоду батьків дитини.

\section{Клінічний випадок}

Хлопчик, 9 років, захворів гостро у вересні 2020 р., коли відбувся напад судом. Судоми супроводжувалися втратою свідомості, мимовільним сечовипусканням. Напад батьки пов'язували з фізичним навантаженням у спекотну погоду.

11.09.2020 пацієнта госпіталізували до неврологічного відділення КНП «Івано-Франківська обласна дитяча клінічна лікарня ІваноФранківської обласної ради» 3 діагнозом «ддіопатична епілепсія, генералізовані клоніко-тонічні судоми». За даними магнітно-резонансної томографії головного мозку: неспецифічне 


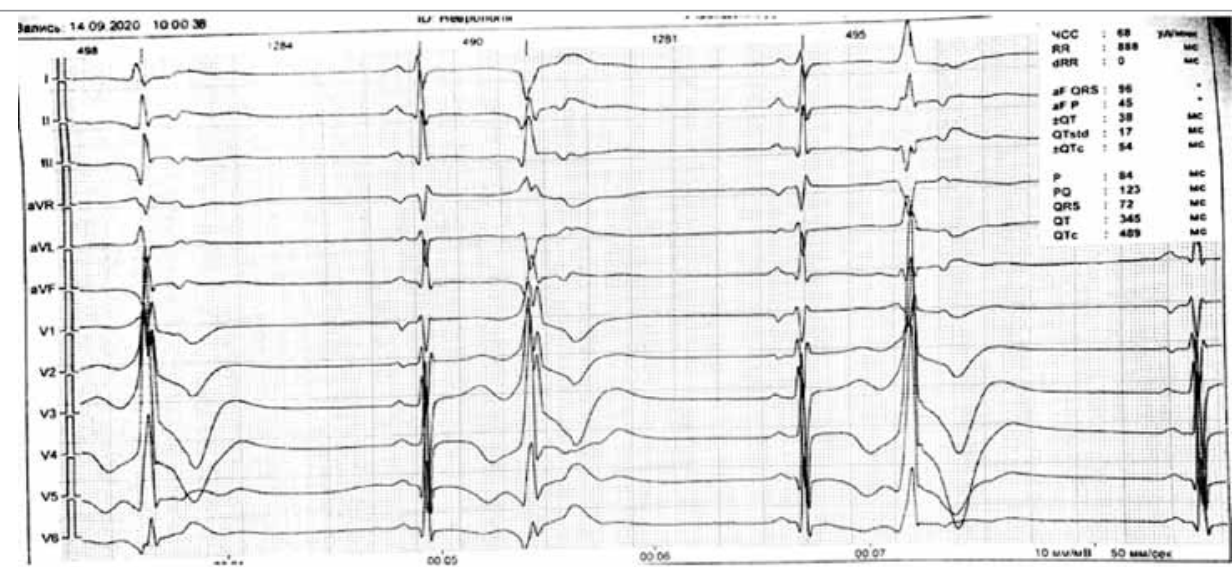

Pис. 1. Шлуночкова бігемінія (ЕКГ, вересень 2020 року)

дрібне вогнище гліозу лівої лобної частки; патологія гіпокампів, ділянки гетеротопії не виявлені. За результатами електроенцефалографії (ЕЕГ): альфа-ритм модульований, симетричний, реакція активації чітка, пароксизмальна активність не зареєстрована, реакція засвоєння ритму при фотостимуляційних пробах чітка, ознаки дисфункції неспецифічних стовбурових структур не виявлені. За даними електрокардіографії (ЕКГ): ритм синусовий, шлуночкова екстрасистолія по типу бігемінії, QT - 345 мс, QTc - 489 мс (рис. 1); утім дитину не скерували на консультацію до кардіолога. Призначили протисудомну терапію (вальпроат натрію - по 150 мг х 2 рази/добу, усередину).

Протягом пів року стан дитини був задовільним. Повторний судомний напад констатували 14.03.2021 (під час богослужіння). Хлопчика повторно в ургентному порядку госпіталізували до неврологічного відділення. 15.03.2021 лікуючий лікар констатував стан клінічної смерті. Дитину в ургентному порядку перевели до відділення інтенсивної терапії, де провели реанімаційні заходи. За 5 год стан клінічної смерті повторився. Протягом 8 год хлопчик перебував на керованому диханні.

16.03.2021 у пацієнта на ЕКГ зафіксували порушення ритму по типу шлуночкової бігемінії, пролонгацію інтервалу QT (0,49 с). Протисудомну терапію відмінили.

16.03.2021-17.03.2021 пацієнту провели холтер-моніторування ЕКГ, під час якого зареєстрували високоступеневу шлуночкову екстрасистолію, шлуночкову двоспрямовану пароксизмальну тахікардію, епізоди фібриляції та тріпотіння шлуночків із подальшою асистолією (рис. 2, 3).

Враховуючи вищеописані дані, встановили діагноз «Синдром подовженого інтервалу QT. Синдром Романо-Уорда? Порушення ритму по типу шлуночкової екстрасистолії (III-V клас за Lown), пароксизмів SVT та фібриляції шлуночків. Напади Морганьї-Адамса-Стокса. Стан після клінічної смерті. СН ІІ ФК. ХНК І».

17.03.2021-18.03.2021 провели інфузійну антиаритмічну терапію аміодароном із розрахунку 5 мг/кг/добу, на тлі якої відмічалася пролонгація інтервалу QT до 0,6 с. 18.03.2021 аміодарон відмінили. 18.03.2021-21.03.2021 провели інфузію розчину $\mathrm{KCl}$ (1 ммоль/кг/добу) та $\mathrm{MgSO}_{4}$ (0,1 мл/кг/добу), розпочали титрування дози протиаритмічного препарату (пропранолол).

22.03.2021 пацієнта перевели на кардіологічне ліжко до нефрологічного відділення. Хлопчик висловлював скарги на момент госпіталізації на періодичне відчуття перебоїв у роботі серця, загальну слабкість, періодичний біль у животі, схильність до закрепів.

У нефрологічному відділенні стан дитини середньої тяжкості. Хлопчик правильної будови, задовільного відживлення. Шкірні покриви та видимі слизові звичайного кольору, чисті, гіперемія щік. Щитоподібна залоза пальпується у вигляді перешийка, неболюча під час пальпації. Перкуторно над легенями - легеневий звук, аускультативно - дихання везикулярне, 3 частотою 20 на хвилину, хрипи не вислуховуються. Межі відносної серцевої тупості не поширені, відповідають вікові. Тони серця аритмічні (часта екстрасистолія), звучність дещо знижена, систолічний шум над верхівкою та V точкою, не провідний, брадикардія (частота серцевих скорочень (ЧСС) - 42-52 уд./хв). Периферійний пульс дещо зниженого наповнення, аритмічний, однаковий на обох руках. Артеріальний тиск - 100-114/44-60 мм рт. ст. Живіт м'який, періодично піддутий, неболючий під час пальпації, бере участь в акті дихання. Печінка, селезінка не збільшені. Діурез 
достатній, сечопуск вільний. Випорожнення 1 раз на 2-3 доби.

За даними загальноклінічних обстежень: лейкоцитоз у загальному аналізі крові $\left(25,1 \times 10^{9} / л\right)$, підвищення рівнів холестерину (5,43 ммоль/л), трапсаміназ (аланінамінотрансферази - 372 ОД), аспартатамінотрансферази 388 ОД)), глюкози $(9,7$ ммоль/л), калію (3,84 мг-екв/л). За результатами коагулограми: протромбіновий час $-14,8$ с, протромбіновий індекс - 85,8\%, міжнародне нормалізоване відношення - 1,13 Од, активований частковий тромбопластиновий час $-52,7$ c, фібриноген 2,04 г/л; прокальцитонін - <0,04 нг/мл, Д-димер - 298,1 нг/мл; у загальному аналізі сечі рівень білка до 0,066 г/л та ацетонурія.

На ЕКГ за результатами кількох обстежень: ритм синусовий, із частотою від 65 до 125 уд./хв, шлуночкова екстрасистолія по типу тригемінії, неповна блокада правої ніжки пучка Гіса, подовження інтервалу QT (QTc-490-511 мс), підвищений вольтаж ЕКГ, альтернація зубця Т, дисметаболічні зміни в міокарді.

За даними ЕхоКГ: діаметр аорти 1,8-2,3-1,8 см, ліве передсердя $-2,9$ см, лівий шлуночок - 4,5 см, кінцево-діастолічний індекс -78 мл/м², міжшлуночкова перетинка 0,75 см, правий шлуночок $-1,9$ см, легенева артерія - 2,0 см, фракція викиду - 54-57\%, регургітація на тристулковому клапані ++, на клапані легеневої артерії - +, сумарна скоротливість збережена, аритмія, асинхронізм скорочення стінок лівого шлуночка, права коронарна артерія -5 мм, ліва $-4,1$ мм.

Повторне холтер-моніторування ЕКГ (на дозі пропранололу 2 мг/кг/добу): непра-

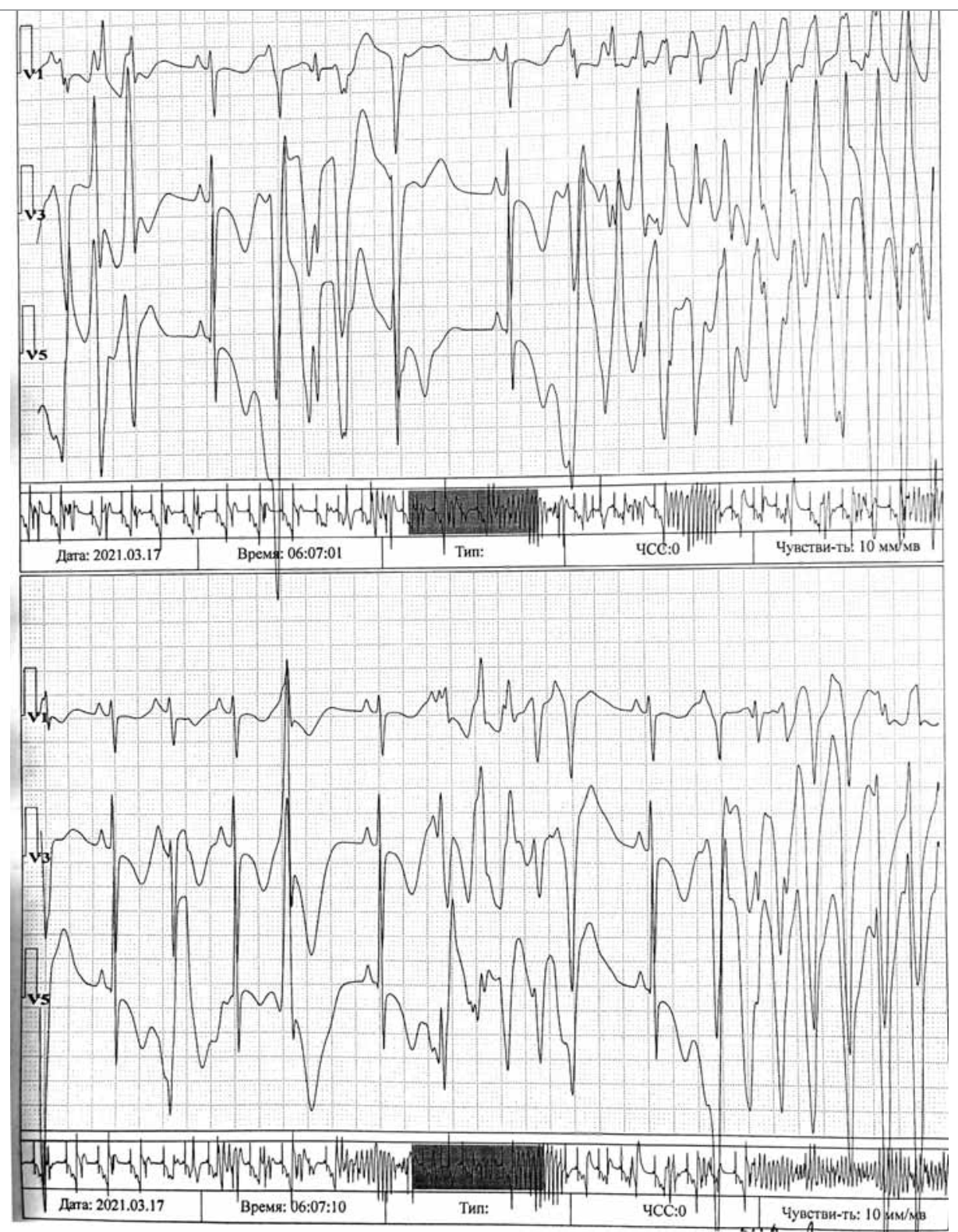

Pис. 2 Епізод двонаправленої шлуночкової пароксизмальної тахікардії за даними Холтер-ЕКГ (березень 2021) 
вильний базовий синусовий ритм, міграція водія ритму, середня ЧСС - 83 уд./хв, максимальна - 135 уд./хв, мінімальна -49 уд./хв, тахікардія - 333 (4 год 23 хв), пароксизми надшлуночкової та шлуночкової пароксизмальної тахікардії (226 і 49 748, відповідно), альтерація зубця Т, шлуночкова алоритмія (бігемінія) 33529 .

За даними динамічного спостереження (на дозі пропранололу 5 мг/кг/добу): неправильний базовий синусовий ритм, середня ЧСС - 79 уд./хв, максимальна - 101 уд./хв, мінімальна - 52 уд./хв, надшлуночкова екстрасистолія - 966, шлуночкова - 35 562, переважно по типу бігемінії, пробіжки шлу- ночкових екстрасистол по 2-4-7 комплексів, реєструються епізоди синусового ритму від 2 хв до 15 хв, QT сер -520 мс.

За даними ЕЕГ: без графоелементів епілептичного кола.

Під час рентгенографічного обстеження органів грудної клітки у прямій проєкції, а також під час ультразвукового дослідження органів черевної порожнини структурні зміни не виявлені.

Медикаментозна терапія цього пацієнта включала аміодарон (16.03.2021-17.03.2021), пропранолол (з 18.03.2021 (нарощення дози 31 мг/кг/добу до 5 мг/кг/добу), макрогол 40001 пак./добу, магне В6 - 1 таблетка

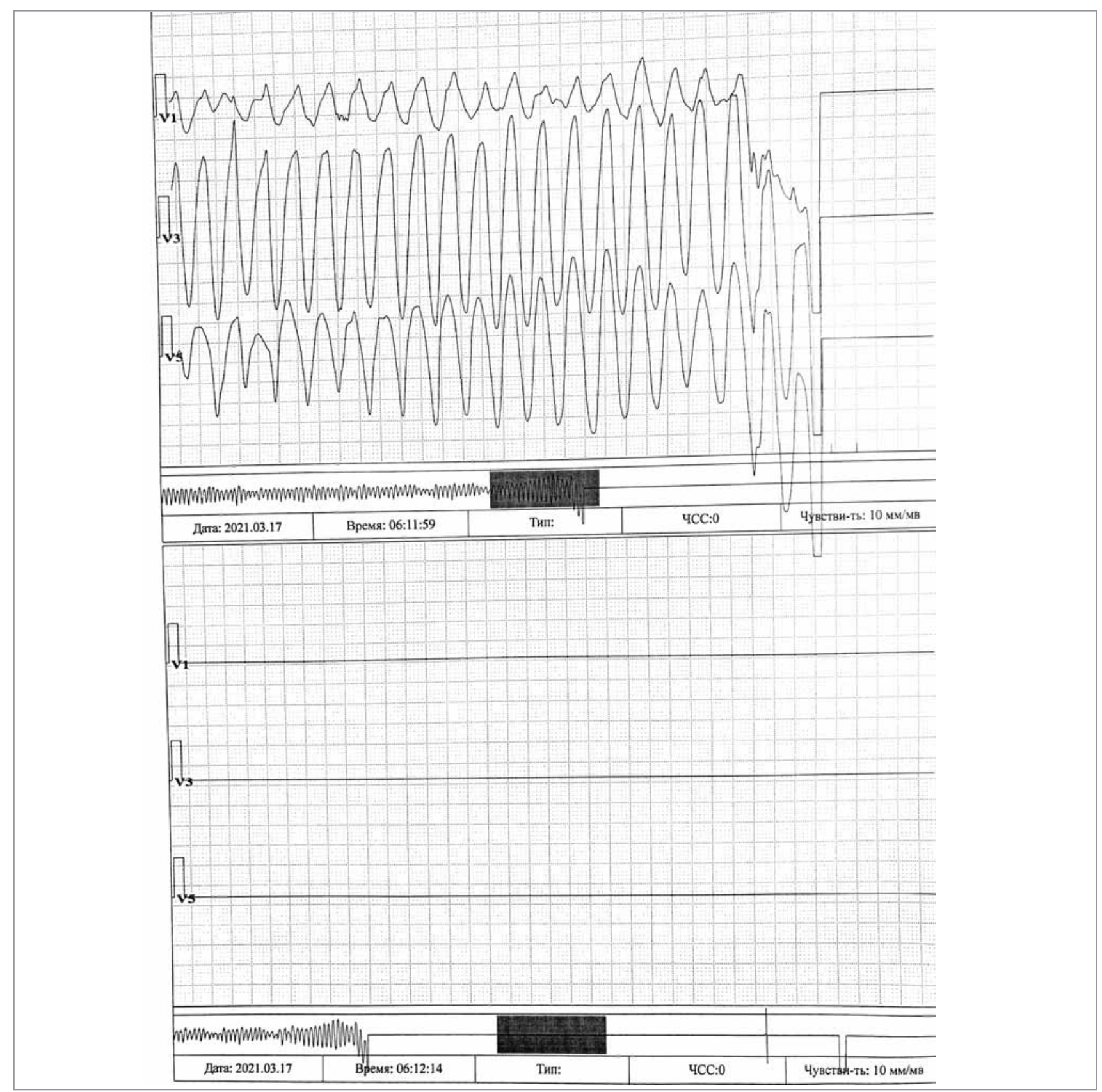

Pис.3. Епізод фрібриляції шлуночків та наступної асистолії за даними Холтер-ЕКГ (березень 2021) 


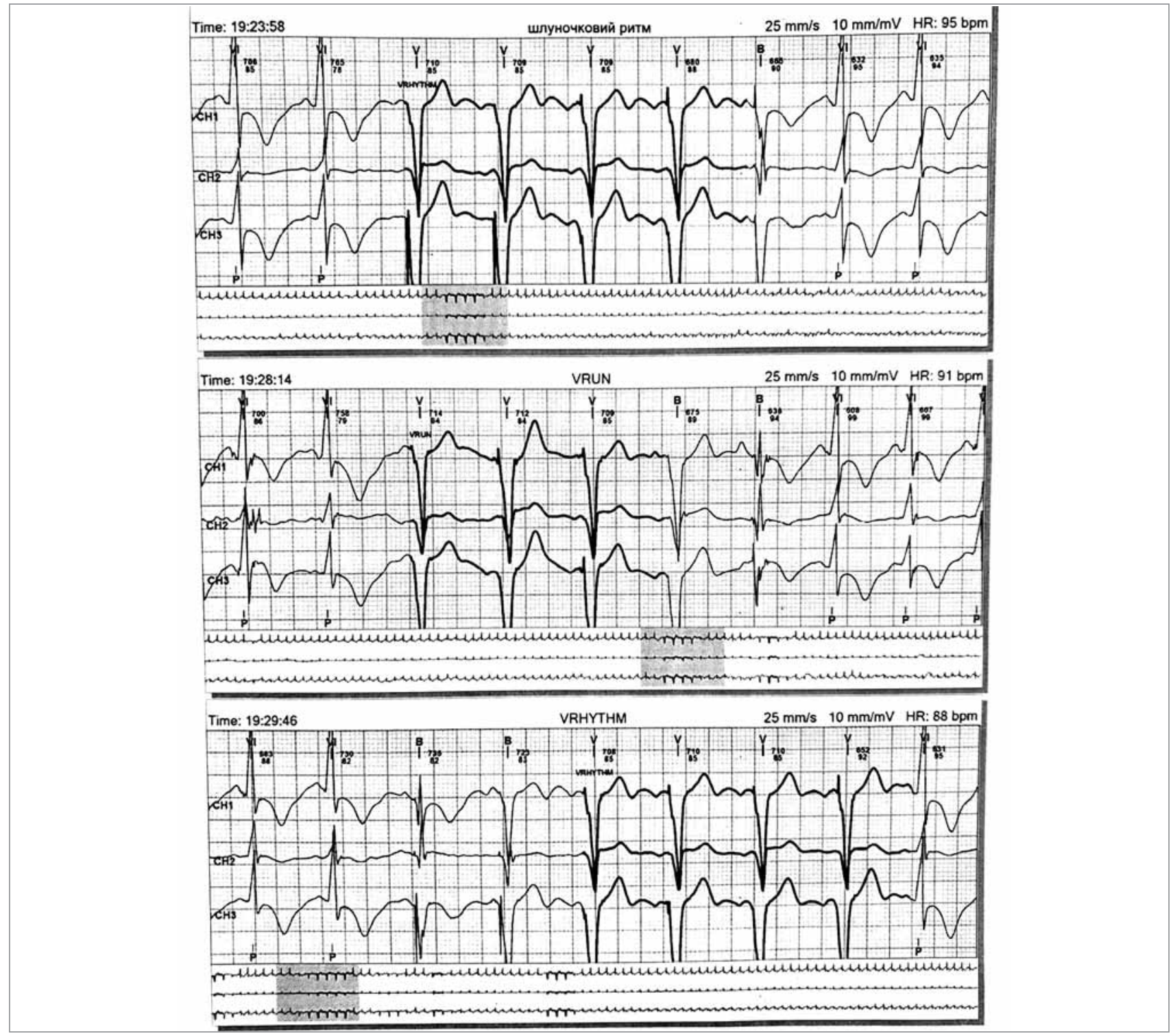

Рис.4. Холтер-ЕКГ пацієнта (листопад 2021 року)

х 3 рази/добу, калію оротат - 1 таблетка х 3 рази/добу).

За час перебування у стаціонарі стан дитини поліпшився. Хлопчика скерували на госпіталізацію до відділення хірургічного лікування порушень ритму Науково-практичного медичного центру дитячої кардіології та кардіохірургії (м. Київ). У цьому центрі хлопчику провели імплантацію ендокардіального двокамерного кардіовертера-дефібрилятора ICD-DR Medronic Protecta DR i встановлено клінічний діагноз «Синдром подовженого інтервалу QT. Стан після раптової серцевої смерті. Стан після імплантації двокамерного ICD-DR Medronic Protecta DR. Шлуночкова екстрасистолія, часта. Пароксизмальна шлуночкова тахікардія (за даними реєстру апарату 6 дефібриляцій)».

Після виписки зі стаціонару хлопчик перебуває під спостереженням кардіолога за місцем проживання, отримує метопролол у дозі 3,8 мг/кг/добу. Провели ЕКГ-обстеження родичів I ступеня спорідненості (батькиі сибси), у результаті якого патологічні зміни не виявлені.

Під час повторного холтер-моніторування ЕКГ (на дозі метопрололу 150 мг/добу): середня ЧСС - 89 уд./хв, максимальна 143 уд./хв, мінімальна -84 уд./хв, політопна екстрасистолія (у тому числі 16 куплетів, 5 пробіжок шлуночкових екстрасистол, 19 епізодів шлуночкової та 3 суправентрикулярної бігемінії, 6 періодів ідіовентрикулярного ритму), QT $\min -343$ мс, QT $\max -484$ мс, QTc $\min -408$ мс, QTc $\max -656$ мс (рис. 4, 5).

Пацієнта повторно скерували з рекомендацією розглянути можливість проведення катетерної деструкції субстрату аритмії. 


\section{Обговорення}

Складність встановлення діагнозу в цьому клінічному випадку обумовлена гострим початком захворювання, що маніфестувало судомним синдромом і детермінувало необхідність призначення протисудомної терапії; недостатньою клінічною інтерпретацією даних ЕКГ; появою клінічної симптоматики у вигляді раптової серцевої смерті. За даними літератури, незважаючи на те, що приблизно 25\% пацієнтів iз LQTS мають нормальний інтервал QT ( $<440$ мс), у них існує ризик розвитку станів, що загрожують життю. Особливу увагу слід звертати на тривалість інтервалу QT у разі необхідності призначення медикаментозних препаратів, що можуть індукувати його пролонгацію $[2,3,9]$. Тому має значення індивідуальна оцінка стану пацієнта, у тому числі дані сімейного анамнезу, ретельна оцінка ризиків, пов'язаних із медикаментозною терапією.

\section{Висновки}

Незважаючи на рідкісність випадків синдрому подовженого QT, ризик виникнення аритмій та синдрому раптової смерті, що загрожують життю, у таких пацієнтів обумовлює необхідність настороженості лікарів первинної ланки та дитячих неврологів щодо цієї патології, включення її до кола диференційного обстеження в пацієнтів із синкопальними

\section{REFERENCES/JITEPATУPA}

1. Antzelevitch C. (2007). Ionic, molecular, and cellular bases of QT-interval prolongation and torsade de pointes. Europace. 9: 4-15. URL: https://doi: 10.1093/europace/eum166.

2. Goldenberg I, Horr S, Moss AJ et al. (2011). Risk for life-threatening cardiac events in patients with genotype-confirmed Long-QT Syndrome and normal-range corrected QT intervals. J Am Coll Cardiol. 57: 51-59. URL: https://doi: 10.1016/j.jacc.2010.07.038.

3. Goldenberg I, Moss AJ. (2008). Long Q-T syndrome J Am Coll Cardiol. 51: 2291-3000. URL: https://doi: 10.1016/j.jacc.2008.02.068.

4. January CT, Gong Q, Zhou Z. (2000). Long QT syndrome: cellular basis and arrhythmia mechanism in LQT2. J Cardiovasc Electrophysiol. 11, 12: 1413-1418. URL: https://doi: 10.1046/j.1540-8167.2000.01413.x.

5. Khrebtiy Gl, Savchuk OV, Suvoryk VA et al. (2016). Congenital elongated interval QT syndrome: state of the art. Reports of Vinnytsia National Medical University. 2 (20): 518-521. [Хребтій ГІ, Савчук ОВ, Суворик ВА та ін. (2016). Вроджений синдром подовженого інтервалу QT:

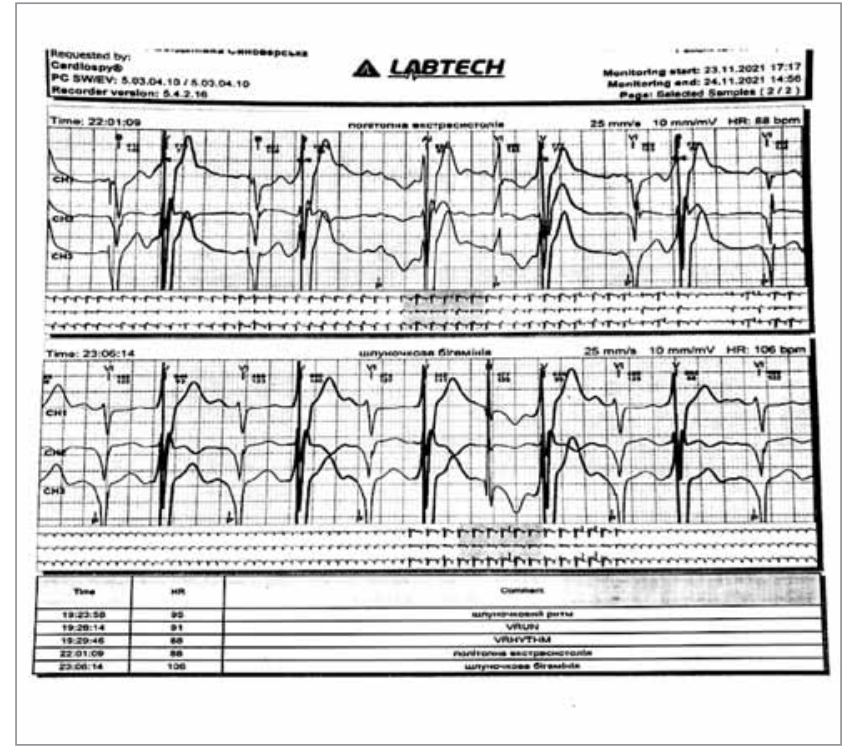

Рис. 5 Холтер-ЕКГ пацієнта (листопад 2021)

станами та судомним синдромом. Оптимальним щодо профілактики випадків раптової серцевої смерті, пов'язаної з цією причиною, стало б проведення щорічного скринінгового ЕКГ-дослідження в дітей перед початком навчального року. Така стратегія оптимізувала б ранню діагностику та застосування вчасної корекції, спрямованих на запобігання виникненню життєво небезпечних ускладнень і поліпшення якості життя пацієнтів.

Автори заявляють про відсутність конфлікmу інтересів.

Відомості про авторів:

\footnotetext{
Синоверська Ольга Богданівна - д.мед.н., проф., зав. каф. дитячих хвороб післядипломної освіти Івано-Франківського НМУ. Адреса: м. Івано-Франківськ, вул. Коновальця, 132. https://orcid.org/0000-0003-1072-3782.

Алексєєва Юлія Іванівна - к.мед.н., доц. каф. педіатрії Івано-Франківського НМУ. Адреса: м. Івано-Франківськ, вул. Коновальця, 132. https://orcid.org/0000-0002-6279-9992.

Рейтмаєр Михайло Йосипович - к.мед.н., доц. каф. педіатрії Івано-Франківського НМУ. Адреса: м. Івано-Франківськ, вул. Коновальця, 132. https://orcid.org/0000-0002-9737-410X Фоменко Надія Миколаївна - к.мед.н., доц. каф. дитячих хвороб післядипломної освіти Івано-Франківського НМУ. Адреса: м. Івано-Франківськ, вул. Коновальця, 132. http://orsid.org/00000001-6992-9182.

Шкандрій Світлана Богданівна - лікар відділення функціональної діагностики КМП «Ф ОДКЛ» КНП «Івано-Франківська ОДКЛ ІФ ОР». Адреса: м. Івано-Франківськ, вул. Коновальця, 132. https://orcid.org/0000-0002-9477-6955.

Стаття надійшла до редакції 17.08.2021 р., прийнята до друку 09.11.2021 р.
} 

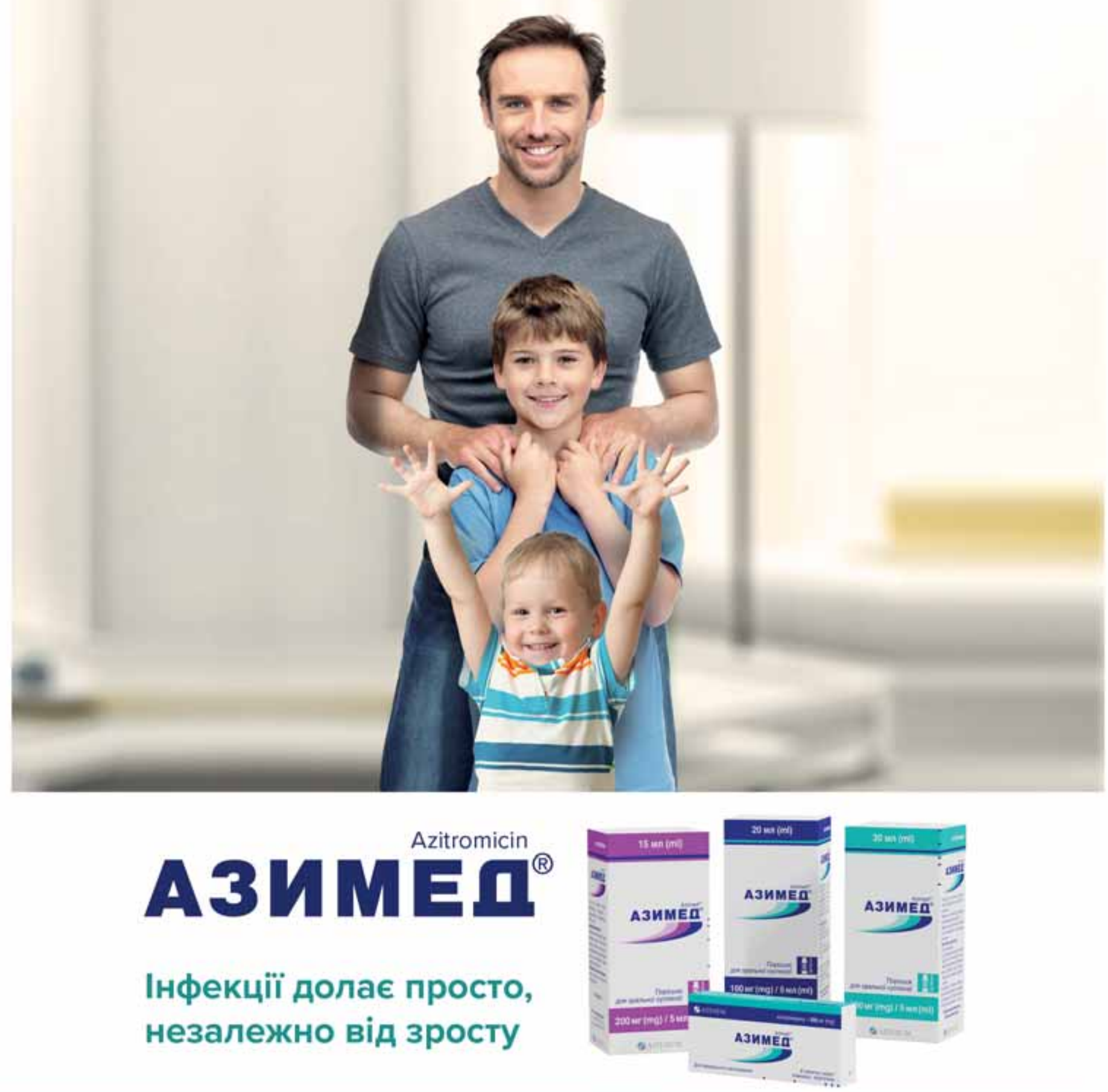

- Доведена біоеквівалентність препарату щодо оригінального засобу

- Простий і ефективний курс лікування, прийом лише 1 раз на день $1,2,5$
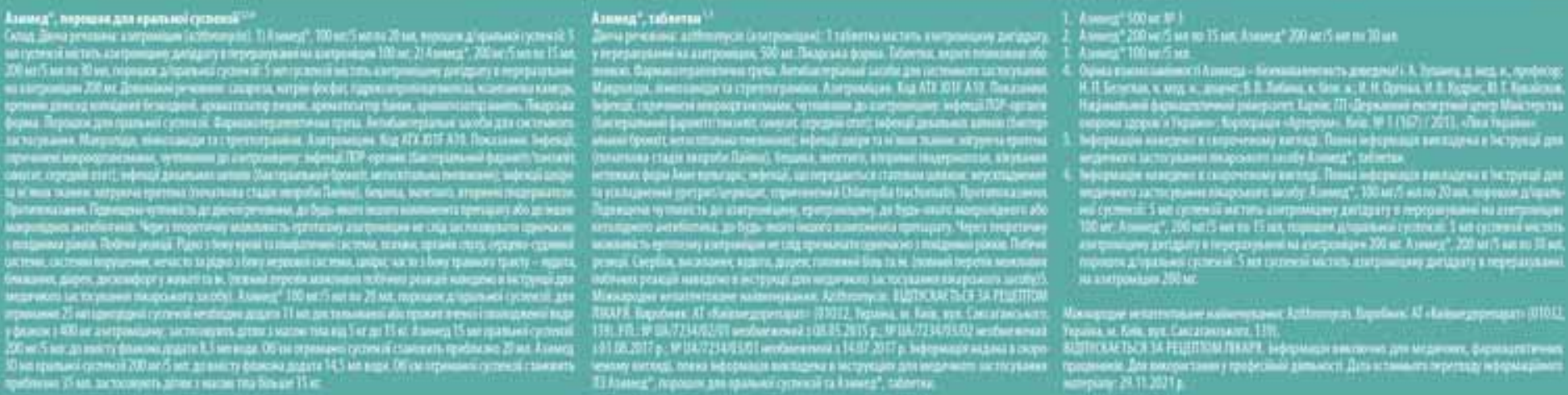

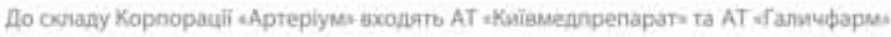

Ближче до пюдей

«Артеріум» Фармацевтична Корпорація

www.arterium.ua 


\title{
С.О. Крамарьов, В.В. Євтушенко \\ Роль азитроміцину в антибактеріальній терапії гострих респіраторних інфекцій у дітей
}

Національний медичний університет імені О.О. Богомольця, м. Київ, Україна

Modern Pediatrics. Ukraine. (2021). 7(119): 63-71. doi 10.15574/SP.2021.119.63

For citation: Kramarov SO, Yevtushenko VV. (2021). The role of azithromycin in the antibacterial therapy of acute respiratory infections in children. Modern Pediatrics. Ukraine. 7(119): 63-71. doi 10.15574/SP.2021.119.63.

Гострі респіраторні інфекції являються провідною причиною захворюваності та смертності в дитячому віці. Антибактеріальна терапія при гострих респіраторних інсекціях має призначатися виважено і за суворими показаннями.

В огляді проаналізовано етіологічну структуру захворювань верхніх і нижніх дихальних шляхів, визначено сучасні погляди на раціональне застосування антибактеріальних засобів при таких захворюваннях, як гострий тонзилофарингіт, риносинусит, бронхіт і пневмонія. Серед розмаїття антибактеріальних засобів найчастіше в педіатричній практиці застосовуються препарати групи макролідів, зокрема азитроміцин. Розглянуто фармакологічні властивості азитроміцину, механізми його антимікробної та імуномодулюючої активності, показання до призначення при гострих респіраторних інсекціях у дітей. Автори заявляють про відсутність конфрлікту інтересів.

Ключові слова: антибіотики, гостра респіраторна інсекція, макроліди, азитроміцин, діти.

\section{The role of azithromycin in the antibacterial therapy of acute respiratory infections in children}

S.O. Kramarov, V.V. Yevtushenko

Bogomolets National Medical University, Kyiv, Ukraine

\begin{abstract}
Acute respiratory infections are the leading cause of morbidity and mortality in childhood. Antibacterial therapy for acute respiratory infections should be prescribed carefully and under strict indications. This review analyzes the etiological structure of diseases of the upper and lower respiratory tract, identifies modern views on the rational use of antibacterial agents in diseases such as acute tonsillopharyngitis, rhinosinusitis, bronchitis and pneumonia. Among the variety of antibacterial agents, macrolide drugs, in particular azithromycin, are most often used in pediatric practice. The pharmacological properties of azithromycin, mechanisms of its antimicrobial and immunomodulatory activity, indications for use in acute respiratory infections in children are considered in the article.
\end{abstract}

No conflict of interest was declared by the authors.

Key words: antibiotics, acute respiratory infection, macrolides, azithromycin, children.

\section{Роль азитромицина в антибактериальной терапии острых респираторных инфекций у детей \\ С.А. Крамарев, В.В. Евтушенко \\ Национальный медицинский университет имени А.А. Богомольца, г. Киев, Украина}

\begin{abstract}
Острые респираторные инсеекции являются ведущей причиной заболеваемости и смертности в детском возрасте. Антибактериальная терапия при острых респираторных инфрекциях должна назначаться четко по строгим показаниям.

В данном обзоре проанализирована этиологическая структура заболеваний верхних и нижних дыхательных путей, определены современные взгляды на рациональное применение антибактериальных средств при таких заболеваниях, как острый тонзилофарингит, риносинусит, бронхит и пневмония. Среди разнообразия антибактериальных средств наиболее часто в педиатрической практике применяются препараты группы макролидов, в частности азитромицин. В статье рассмотрены фармакологические свойства азитромицина, механизмы антимикробной и иммуномодулирующей активности, показания к назначению при острых респираторных инфекциях у детей.
\end{abstract}

Авторы заявляют об отсутствии консрликта интересов.

Ключевые слова: антибиотики, острая респираторная инсекция, макролиды, азитромицин, дети.

$\Gamma$ острі респіраторні інфекції (ГРІ) є провідною причиною захворюваності та смертності в дитячому віці. За розрахунками Всесвітньої організації охорони здоров'я (ВООЗ), щороку у 2017 р. від ГРІ гине понад 800 тис. дітей віком до 5 років [41]. У більшості випадків тяжкий і часто фатальний перебіг пов'язаний $з$ інфекціями нижніх дихальних шляхів. На цей час стратегія зі зменшення тягаря ГРІ полягає у профілактиці їх виникнення інфекцій та в запобіганні тяжких наслідків у пацієнтів, які вже захворіли [34]. Профілактичний напрям передбачає широке охоплення населення профілактичними щепленнями проти найпоширеніших i найактуальніших збудників респіраторних захворювань, таких 
як віруси грипу та SARS-CoV-2, пневмокок, коклюш, дифтерія та гемофільна паличка. У разі, коли хвороба вже розпочалася, на перший план виходить оптимальна тактика ведення пацієнта, в якій чільне місце належить раціональному застосуванню антибактеріальної терапії.

У цьому огляді розглянуто показання до призначення антибактеріальної терапії при ГРІ в дітей.

Гострі респіраторні захворювання традиційно поділяються на інфекції верхніх і нижніх дихальних шляхів. До інфекцій верхніх дихальних шляхів, відповідно до Міжнародної класифікації хвороб 10-го перегляду (МКХ-10), належить риніт, фарингіт, тонзиліт, ларингіт і трахеїт; до інфекцій нижніх дихальних шляхів бронхіт, бронхіоліт і пневмонія. У переважній більшості випадків ГРІ в дітей мають нетяжкий перебіг, проходять самостійно і не загрожують життю пацієнта. За таких обставин тактика ведення полягає в призначенні підтримувальної (достатня аерація, профілактика дегідратації) та симптоматичної терапії. Призначення антибактеріальної терапії в кожному випадку має бути виваженим та обгрунтованим. Нижче наведено ситуації, при яких антибактеріальну терапію можна розглядати для лікування ГРІ.

\section{Гострий риносинусит}

Риносинусит - це запалення носа і приносових пазух, для нього характерна наявність не менше 2 симптомів, одним 3 яких мають бути виділення з носа або закладеність носа [44]. Так само у хворих можуть бути болі або відчуття розпирання в ділянці обличчя. У дітей риносинусит часто супроводжується кашлем, а в дорослих - зниженням нюху. Гострий синусит у 78\% випадків у дітей має бактеріальну природу [23]. Приблизно від 5\% до 10\% вірусних захворювань верхніх дихальних шляхів ускладнюються гострим бактеріальним синуситом. Вірусне захворювання верхніх дихальних шляхів є найпоширенішим фактором для розвитку бактеріального синуситу в дитячому віці і реєструється у $80 \%$ випадків бактеріальних синуситів. Алергічна природа запалення є основою інших 20\% випадків гострого бактеріального синуситу в дітей. Найчастіше синусити викликаються Streptococcus pneumoniae, Haemophilus influenzae і Moraxella catarrhalis. При цьому Streptococcus pneumoniae виділяється в 40\% випадків, Haemophilus influenzae i Moraxella catarrhalis приблизно у $20 \%$ випадків кожний. Рідше виді- ляються стрептококи групи А, стафілококи, Peptostreptococcus spp, Eikenella corrodens. Анаеробні бактерії зазвичай не виділяються в пацієнтів із гострим синуситом [44].

Імовірність гострого бактеріального риносинуситу є досить високою за наявності одного з таких клінічних проявів: тривалість симптомів протягом понад 10 діб, гнійний характер виділень із носа, сильний локалізований однобічний біль (особливо біль над зубами та щелепою), лихоманка, помітне погіршення стану після початкового періоду з легшими проявами [30].

Антибіотики слід призначати дітям із гострим бактеріальним синуситом при тяжкому перебігу хвороби, погіршенні захворювання або стійкому збереженні симптоматики понад 10 діб [45]. Негайно потрібно почати антибактеріальну терапію в разі наявності (чи підозри) тяжкої системної інфекції (сепсис), при симптомах внутрішньоорбітальних або періорбітальних ускладнень, у тому числі періорбітальному набряку або целюліті, зміщенні очного яблука, диплопії, офтальмоплегії або швидкому зниженні гостроти зору, при внутрішньочерепних ускладненнях, у тому числі набряку над лобовою кісткою або ознаках менінгіту, сильному лобному головному болю або фокальних неврологічних ознаках [30].

\section{Гострий тонзиліт}

Терміни «тонзиліт» і «фарингіт» вживаються для визначення гострого запалення піднебінних мигдаликів або слизової оболонки глотки відповідно. Враховуючи близьке анатомічне розташування і часто одночасне залучення до запального процесу обох структур, у літературі та практичній діяльності також вживається термін «тонзилофарингіт». Донедавна у вітчизняній літературі для визначення гострого запалення структур лімфоглоткового кільця часто вживався термін «ангіна». Гострий тонзилофарингіт (ГТФ) належить до поширених інфекційних захворювань у педіатричній практиці і становить у структурі гострих респіраторних захворювань (ГРЗ) не менше 15\% [38].

У переважній більшості випадків причиною ГТФ є інфекційне ураження. Збудниками захворювання можуть бути віруси, бактеріальні патогени та гриби. Вважається, що 50-80\% усіх випадків ГТФ обумовлені вірусною етіологією [48]. Широке коло вірусів може асоціюватися з ГТФ, зокрема, це вірус Ебштейна-Барра, риновірус, аденовірус, віруси грипу та парагри- 
пу, віруси Коксакі, коронавірус, еховірус, цитомегаловірус тощо [36]. Здебільшого клінічні симптоми ГТФ є частиною ширшого симптомокомплексу ГРІ. Клінічна картина цих захворювань зазвичай неспецифічна, хоча при деяких інфекціях характерна наявність специфічних симптомів.

Приблизно 30\% ГТФ у дітей виникають унаслідок бактеріальної інфекції [38]. Серед бактеріальних збудників у багатьох випадках етіологічна роль належить бета-гемолітичному стрептококу групи А (БГСА). Рідше захворювання викликаються Pneumococcus, Staphylococcus aureus, Haemophilus Influenzae, Moraxella catarhalis, Fusobacterium necrophorum, Streptococcus (групи В, C, G), Chlamydia pneumoniae, Corynebacterium diphtheriae, гриби (Candida albicans, Rhinosporidium, Cryptococcus, Histoplasma) [23]. Антибактеріальна терапія призначається при бактеріальному тонзилофарингіті, обумовленому бета-гемолітичним стрептококом групи А, коринебактерією дифтерії та некробацильозом.

Бета-гемолітичний стрептокок (Streptococcus pyogenes) належать до патогенних мікроорганізмів. Важливість цього збудника з медичної точки зору полягає не лише в частоті випадків гострої інфекції, але й у тому, що він може провокувати тяжкі імунопатологічні захворювання, такі як гостра ревматична лихоманка та постстрептококовий гломерулонефрит. Максимальна захворюваність на стрептококовий фарингіт спостерігається в дітей віком від 5 до 15 років, де на цей збудник припадає понад $20 \%$ випадків гострого фарингіту. Стрептококовий фарингіт значно рідше зустрічається серед дітей перших 3 років життя і в дорослих. Інфекція може зустрічатись у вигляді спорадичних випадків, а може бути причиною спалахів у дитячих колективах. Клінічна картина гострого БГСА тонзилофарингіту звичайно характеризується болем у горлі, високою лихоманкою, головним болем, нудотою, блюванням, болем у животі, яскравою гіперемією мигдаликів і піднебінних дужок, а також задньої стінки глотки, гнійними нашаруваннями на мигдаликах, петехіальними висипами на твердому піднебінні (енантема), збільшенням підщелепних лімфатичних вузлів, появою скарлатиноподібного висипу на шкірі, сезонністю захворювання в холодну пору року [4]. За результатами дослідження Nishiyama [31], найсильнішу кореляцію з БГСА-етіологією в дітей мають такі симптоми, як висип, набряк регіонарних лімфа- тичних вузлів, набряк мигдаликів i/або 3 наявністю нашарувань, холодна пора року та відсутність кашлю.

Іншою важливою бактеріальною інфекцією глотки є Fusobacterium necrophorum (некробацильоз). $Є$ повідомлення, що його етіологічна роль у структурі ГТФ не поступається навіть стрептококу [43]. Цей мікроб асоціюється 3 тяжкими паратонзилярними абсцесами та синдромом Лам'єра. Останній являє собою тяжке, часто смертельне захворювання, що характеризується розвитком тромбофлебіту внутрішньої яремної вени внаслідок прогресування бактеріального фарингіту [1]. Захворювання зазвичай починається 3 лихоманки, що досягає $39-41^{\circ} \mathrm{C}$, та може супроводжуватись ознобом. Раннім симптомом є біль у горлі, який частіше з'являється за 4-5 діб до появи інших симптомів. Клінічна картина в глотці неспецифічна і може варіювати від незначних катаральних змін до тяжкого ексудативного тонзиліту 3 порушенням ковтання. Зазвичай має місце реакція лімфовузлів. Розвиток регіонарної лімфаденопатії може бути одно- або двобічним і супроводжуватися больовими відчуттями в шиі. Хворі також інколи скаржаться на відчуття ущільнення в ділянці яремної вени. Розвиток тромбофлебіту супроводжується дисемінацією септичних тромбів до різних органів, зокрема в легені, дещо рідше - в суглоби, мозкові оболонки, кістки, печінку, із розвитком вогнищевих уражень [11].

Антибактеріальна терапія також показана в лікуванні ГТФ, який викликається грампозитивною бактерією Corynebacterium diphtheri$a e$. Захворювання зазвичай починається після інкубаційного періоду, який триває 2-5 діб. Перші симптоми захворювання неспецифічні і нагадують звичайну ГРІ. При фарингоскопії в цей період можна виявити катаральні явища та збільшення мигдаликів. Згодом дифузія токсинів дифтерійної палички призводить до фібринозного запалення з формуванням на поверхні мигдаликів характерних щільних нашарувань, які тяжко відділяються від підлеглих тканин епітелію. Ці нашарування можуть розташовуватися на мигдаликах, а можуть розповсюджуватися також на оточуючі тканини. Характерним для дифтерії $€$ розвиток набряку, який з мигдаликів поширюється на паратонзилярну клітковину, м'яке піднебіння та згодом сходить на шию і верхню частину грудної клітки. Без лікування у хворих прогресують токсичні ураження, зокрема 
міокардит, нейропатія, ураження нирок, коагуляційні розлади, порушення гемодинаміки [6]. Захворювання характеризується високим рівнем летальності, що коливається в межах $5-10 \%$ [10].

\section{Гострий бронхіт}

Гострий бронхіт належить до найпоширеніших захворювань дитячого віку. Він являє собою захворювання нижніх дихальних шляхів, яке розвивається внаслідок запалення трахеї, бронхів або бронхіол. У країнах Європи частота гострого бронхіту становить 20-28\% [9]. На цей час немає загальноприйнятого визначення гострого бронхіту. Здебільшого під цим терміном розуміють клінічний синдром, який характеризується наявністю кашлю (сухого або продуктивного), ознак ураження нижніх дихальних шляхів за відсутності хронічної патології дихальних шляхів або іншої встановленої причини кашлю [21].

За сучасними поглядами, бронхіти здебільшого викликаються вірусними агентами. До найпоширеніших вірусів належать віруси грипу A та B, вірус парагрипу, респіраторносинцитіальний вірус, риновірус, коронавірус, аденовірус, людський метапневмовірус [46]. Так, за даними ретроспективних досліджень у Словенії та Англії, провідною причиною гострих інфекцій нижніх дихальних шляхів у дітей віком до 5 років є респіраторно-синцитіальний вірус [35,42]. В іншому дослідженні серед немовлят частіше виявлявся риновірус (42\%), рідше - респіраторно-синцитіальний вipyc (20\%), вірус парагрипу (16,8\%) і коронавірус (17,6\%) [24]. Дослідження в дорослих пацієнтів із гострим бронхітом свідчать про переважання в етіологічній структурі риновіpусу (25,8\%) і коронавірусу (3,8\%) [23].

Окрім вірусів, в етіології гострого бронхіту відіграє роль також бактеріальна флора. Вона може бути первинною інфекцією або виступати як вторинний агент на тлі первинної вірусної інфекції. Питома вага бактеріальної флори в структурі гострих бронхітів варіює в різних дослідженнях. Зокрема, це пов'язано з технікою лабораторного підтвердження патогенів. Дослідження гострих інфекцій нижніх дихальних шляхів, де методом верифікації етіології обрано бактеріологічне дослідження, зазвичай супроводжується низькою частотою виявлення бактеріальних агентів. Так, у дослідженні серед 116 дітей з ГРІ, в якому проведено бактеріологічне дослідження крові, частота виявлення
Streptococcus pneumoniae становило лише 1\% [14]. Застосування останніми роками в дослідженнях більш чутливих методів діагностики (полімеразна ланцюгова реакція - ПЛР, серологічні тести) збільшило кількість розшифрованих випадків і розширило спектр виявлених збудників. У нещодавньому дослідженні серед дорослих пацієнтів із гострими інфекціями нижніх дихальних шляхів вірусна етіологія захворювання визначалася в 17,2\% хворих, бактеріальна - у 36,7\% і змішана - у 18,9\% (вірус плюс бактерія). Спектр бактеріальних збудників представлений Haemophilus influenzae y 13,4\%, Streptococcus pneumoniae - y 10,3\%, Klebsiella pneumonia - 6,9\%, атипові бактеріi (Mycoplasma pneumoniae, Chlamydophila pneumoniae, Legionella pneumophila, Bordetella pertussis) - у 15,1\% [23]. В одному з досліджень серед немовлят із ГРI нижніх дихальних шляхів у 94,4\% виявлялися бактеріальні патогени, такі як Mycoplasma pneumonia, Chlamydia pneumonia та Streptococcus pneumonia [24]. Існує обгрунтована гіпотеза, що на превалювання бактеріальної етіології ГРІ в дітей впливає, між іншим, наявність супутньої патології. Преморбідна патологія може спрчиняти колонізацію патогенною флорою та підвищувати ризик бактеріальної інфекції. Так, у дослідженні T. Hoshina (2010) серед 106 випадків підтвердженої бактеріальної етіології гострих інфекцій нижніх дихальних шляхів у переважної більшості (73,6\%) дітей була ідентифікована супутня патологія (хронічні захворювання дихальних шляхів, імунологічна недостатність, генетичні дефекти тощо) [19].

Гострий бронхіт у дітей зазвичай починається із симптомів ураження верхніх дихальних шляхів у вигляді гострого риніту. За 3-4 дні від початку захворювання поступово починає наростати непродуктивний кашель, який часто супроводжується больовими відчуттями за грудиною, що посилюються під час кашлю. Інколи в'язке мокротиння та сильні напади кашлю можуть провокувати блювання. Упродовж декількох діб кашель зазвичай набуває продуктивного характеру та супроводжується виділенням мокротиння. Мокротиння має слизовий характер і може бути забарвлене, маючи зовні характер гнійного ексудату. Забарвлення спричиняється пероксидазою лейкоцитів, яка i викликає зміни кольору, тому сам по собі колір не завжди свідчить про бактеріальну природу захворювання i може спостерігатися при вірусних інфекціях. Упродовж наступних 
5-10 діб виділення стають менш в'язкими і кашель поступово зменшується [22]. Кашель може зберігатися від 10 до 20 діб при гострому бронхіті, а іноді може тривати до 4 тижнів i більше [25,40]. Загальні симптоми у вигляді нездужання можуть тривати ще декілька діб після нормалізації респіраторної симптоматики [22].

На цей час вважається, що переважна більшість випадків інфекцій нижніх дихальних шляхів не потребує специфічної терапії. Це пов'язано з тим, що здебільшого вони мають вірусну природу і проходять самостійно. Антибактеріальну терапію при гострому бронхіті за рекомендаціями провідних настанов слід призначати в пацієнтів із тяжким загальним станом, при виявленні симптомів, які свідчать про наявність тяжких захворювань або ускладнень, таких як пневмонія, мастоїдит, перитонзилярний абсцес, інтраорбітальні або інтракраніальні ускладнення. Крім того, антибіотики показані пацієнтам із супутньою патологією, яка збільшує ризик ускладнень. До таких належать недоношені діти, особи з патологією серця, бронхолегеневої системи, нирок, гепатобіліарної системи, муковісцидозом, імуносупресією тощо. Широко застосовується підхід, за яким антибіотики можуть бути рекомендовані дітям із гострим бронхітом, якщо лихоманка персистує понад 24-48 годин та асоціюється 3 тахіпное та втяжінням піддатливих місць грудної клітки $[8,29]$. Серед окремих етіологічних факторів гострих захворювань нижніх дихальних шляхів етіотропна терапія зазвичай рекомендується при коклюші [2,39].

Позалікарняна пневмонія $є$ найпоширенішою причиною смерті дітей у світі, на неї припадає 15\% смертей у дітей віком до 5 років. В етіології такої пневмонії можуть відігравати роль як вірусні, так і бактеріальні збудники. За даними літератури, 30-73\% випадків вірусної пневмонії в дітей обумовлені вірусами, які особливо переважають у дітей віком до 5 років. Близько 25\% дітей мають вірусно-бактеріальну природу вірусної пневмонії. Найчастіше патогенами при пневмонії в дітей є респіраторносинцитіальний вірус (28\%), риновірус (27\%), метапневмовірус (13\%), Streptococcus pneumoniae (4-73\%), аденовірус (11\%), Mycoplasma pneumoniae (8-14\%), вірус парагрипу (7\%), грипу (7\%), коронавірус (5\%), Chlamidia pneumoniae (9\%), Haemophilus influenzae, Staphylococcus aureus (1\%) та Streptococcus pyogenes $(<1 \%)$ [23]. Останніми роками спостерігається тенденція до зниження частоти виділення Streptococcus pneumoniae при вірусній пневмонії в дітей зі збільшенням частки Mycoplasma pneumoniae. Наприклад, у США та Китаї в дітей 3 вірусною пневмонією частота виділення Streptococcus pneumoniae становить 3-4\%, а Mycoplasma pneumoniae - 23-32,4\% [23,45]. При цьому частота виділення Mycoplasma pneumoniae зростає з віком: від $2 \%$ у дітей віком до 2 років до $23 \%$ у дітей віком $10-17$ років [20,28,32].

Хоча пневмонія в дітей зазвичай викликається вірусними організмами, у переважній більшості випадків емпіричне лікування передбачає антибіотики. Це відбувається тому, що клінічно складно відрізнити пацієнтів із бактеріальною пневмонією від хворих на вірусні захворювання [17].

Вибір антибактеріального засобу для лікування респіраторних захворювань у дітей грунтується на основі ймовірної етіології інфекційного організму, віку та клінічного стану хворого. На цей час до антибактеріальних засобів, які найчастіше призначаються у світі, належать макроліди, зокрема азитроміцин [26]. Азитроміцин - це антибіотик із групи макролідів, класу азалідів. 3 моменту створення на початку 80-х років XX століття і дотепер він залишається одним із тих антибактеріальних препаратів, які найчастіше призначаються лікарями та внесені ВООЗ до переліку основних лікарських засобів для дітей $[47,49]$.

Висока частота призначення азитроміцину зумовлена клінічною ефективністю, високим профілем безпеки, багатогранністю механізмів дії та особливостями фармакокінетики. Зв'язуючись 3 50S-субодиницею бактеріальної рибосоми, азитроміцин блокує процеси транспептидації та/або транслокації, пригнічує синтез білка, уповільнюючи ріст і розмноження бактерій. Азитроміцин має переважно бактеріостатичний механізм дії, але за певних умов (залежить від мікроорганізму, концентрації антибіотика та $\mathrm{pH}$ середовища) може проявляти бактерицидну дію. Азитроміцин активний проти грампозитивних аеробів (Streptococcus pyogenes, метицилінчутливий Staphylococcus aureus, пеніцилінчутливий Streptococcus pneumoniae), грамнегативних аеробів (Haemophilus influenzae, Haemophilus parainfluenzae, Legionella pneumophila, Moraxella catarrhalis, Pasteurella multocida, Neisseria gonorrhoeae), анаеробів (Clostridium perfringens, Fusobacterium spp., Prevotella spp., Porphyriomonas spp.), внутрішньоклітинних та інших мікроорганізмів (Chlamydia 
trachomatis, Chlamydia phneumoniae, Chlamydia psittaci, Mycoplasma pneumoniae, Mycoplasma hominis, Borrelia burgdorferi).

Ефективно накопичуючись у клітинах, особливо у фагоцитах, він доставляється у високих концентраціях до місць інфекції. Азитроміцин має тривалий період напіврозпаду та великий обсяг розподілу, хоча концентрації в сироватці залишаються низькими. У дослідженнях in vivo показано, що концентрації азитроміцину в альвеолярних макрофагах i тканинах легень до 100\% вищі, ніж у плазмі [16]. Уже до кінця 1-ї доби після застосування азитроміцину в місці запалення накопичується концентрація, що перевищує мінімальну переважну концентрацію для більшості патогенів. Азитроміцин досягає високих концентрацій у місцях зараження внаслідок постійної доставки лікарського засобу лізосомами в циркулюючих фагоцитуючих клітинах, які є джерелом ефективних концентрацій лікарського засобу в тканинах за багато діб після того, як лікарський засіб очищений від сироватки. Існують припущення, що високі концентрації лікарського засобу у вогнищі запалення після фагоцитозу дають змогу подолати низький рівень стійкості збудників до антибіотика, за рахунок чого препарат має високу клінічну ефективність [3].

Крім антибактеріального ефекту, макроліди мають також протизапальний, імуномодулюючий і мукорегулюючий ефекти [50], що вигідно відрізняє їх від інших груп антибіотиків і підвищує їх клінічну ефективність.

Макроліди, зокрема азитроміцин, відновлюють баланс різних субпопуляцій Т-хелперів, регулюють синтез прозапальних цитокінів (пригнічують синтез і секрецію прозапальних інтерлейкінів - ІЛ (ІЛ-1, ІЛ-6, ІЛ-8, TNF- $\alpha$ ) і підсилюють ІЛ-2, ІЛ-4, ІЛ-10). Азитроміцин значно знижує експресію прозапального інтерлейкіну-1 $\beta$, хемокінового ліганду CC (CCL)-2 i TNF- $\alpha$ в альвеолярних макрофагах не тільки при гострому запаленні, але й у пацієнтів із хронічними захворюваннями органів дихання (наприклад, при муковісцидозі) [27]. Також азитроміцин зменшує гостре й хронічне запалення дихальних шляхів при бронхіолітах вірусної етіології (наприклад параміксовірусної) [7].

Азитроміцин здатний знижувати в'язкість та еластичність бронхіального й назального секрету, зменшувати продукцію мокротиння келихоподібними клітинами при її надлишковій секреції, посилює мукоциліарний кліренс [36]. В експериментальних умовах на щурах і на моделі епітеліальних клітин носа людини виявлено, що пероральне введення азитроміцину в дозі 5-10 мг/кг має пряму інгібіторну дію на гіперсекрецію слизу, спричинену алергічним запаленням, стимуляцією ліпополісахаридами, Pseudomonas aeruginosa, Chlamydophilia pneumoniae [51]. Азитроміцин значно інгібує секрецію MUC5AC, індуковану фактором некрозу пухлин $\alpha$ (TNF- $\alpha)$, та експресію мРНК MUC5AC. При цьому джозаміцин та ампіцилін не виявляє подібного ефекту [37]. Таким чином, азитроміцин має перевагу перед іншими антибактеріальними препаратами в лікуванні пацієнтів із наявністю густого в'язкого мокротиння та при утрудненій евакуації мокротиння з бронхолегеневої системи.

Виявлено, що азитроміцин посилює епітеліальні бар'єри дихальних шляхів за допомогою активації метаболізму ліпідів та індукції експресії різних підкласів у межах епідермального диференціювання, що посилює щільні контакти в епітеліальних клітинах бронхів [5]. Можливо, саме з цим пов'язане зменшення загострень у пацієнтів з астмою при тривалому застосуванні азитроміцину (протягом 48 тижнів) [15].

У складі біоплівок бактерії набувають підвищеної здатності до виживання, розвитку полірезистентності до антибіотиків, стійкості до гуморальних і клітинних факторів захисту макроорганізму. У численних дослідженнях азитроміцин виявляє здатність зменшувати утворення повністю полімеризованих альгінатних біоплівок (на прикладі Pseudomonas aeruginosa) та підвищувати чутливість патогенів до комплементу. При цьому у стаціонарній фазі азитроміцин виявляє бактерицидну дію [18].

Завдяки широкому антибактеріальному спектру проти Streptococcus pneumonia, Moraxella catarrhalis та атипових збудників азитроміцин широко використовується в лікуванні дитячих інфекційних захворювань і став одним 3 антибіотиків, які найчастіше призначаються дітям [52]. Азитроміцин показаний для лікування пацієнтів з інфекціями легкого й середнього ступеня тяжкості, спричиненими чутливими штамами мікроорганізмів. Зокрема, азитроміцин рекомендується при гострому середньому отиті, спричиненому Haemophilus influenzae, Moraxella catarrhalis або Streptococcus pneumoniae; при негоспітальній пневмонії, викликаній Chlamydophila pneumoniae, Haemophilus influenzae, Mycoplasma pneumoniae або Streptococcus pneumoniae. Азитроміцин застосовується як перша лінія лікування та 
профілактики коклюшу, а також у лікуванні дифтерії. При фарингіті та тонзиліті стрептококової етіології (Streptococcus pyogenes), при синуситі цей препарат як альтернатива рекомендується особам, які не можуть отримувати терапію першої лінії [13].

На фармацевтичному ринку України препарат азитроміцину представлений під торговою

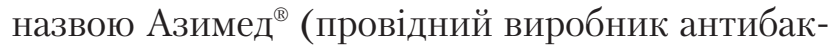
теріальних препаратів АТ «Київмедпрепарат», що входить до складу корпорації «Артеріум»). Дослідження біоеквівалентності препаратів лінійки Азимед ${ }^{\circledast}$ (таблетки, вкриті плівковою оболонкою, 500 мг, порошок для оральної суспензії 200 мг / 5 мл у флаконі, порошок для оральної суспензії 100 мг / 5 мл у флаконі, виробництва ПАТ «Київмедпрепарат», Україна) і Сумамед ${ }^{\circledast}$ (виробництва «Pliva», Хорватія) відповідних форм випуску проведено в клінікодіагностичному центрі на базі Національного фармацевтичного університету. Результатом проведених досліджень є висновок про встановлену біоеквівалентність досліджуваних препаратів. 3 точки зору доказової медицини біоеквівалентні препарати є взаємозамінними [53].

Отже, завдяки унікальним фармакокінетичним і фармакодинамічним характеристикам, імуномодулюючій, протизапальній та секретолітичній дії азитроміцин є ефективним препаратом для антибактеріальної терапії ГРІ в дітей.

Автори заявляють про відсутність конфлікту інтересів.

\section{REFERENCES/JITEPATУPA}

1. Al Duwaiki SM, Al Barwani AS, Taif S. (2018). Lemierre's syndrome. Oman Med J. Oman Medical Specialty Board. 33: 523-526.

2. Amirthalingam G, PGG. (2016). Guidelines for the Public Health Management of Pertussis. Heal Prot Agency. Public Health England: 13-16.

3. Amsden GW. (1999). Pneumococcal macrolide resistance - myth or reality? J Antimicrob Chemother. Oxford Academic. 44: 1-6. URL: https://academic.oup.com/jac/article/44/1/1/750516.

4. Anjos LMM, Marcondes MB, Lima MF, Mondelli AL, Okoshi MP. (2014). Streptococcal acute pharyngitis. Rev Soc Bras Med Trop. Sociedade Brasileira de Medicina Tropical. 47: 409-413.

5. Arason AJ, Joelsson JP, Valdimarsdottir B, Sigurdsson S, Gudjonsson A, Halldorsson $S$ et al. (2019). Azithromycin induces epidermal differentiation and multivesicular bodies in airway epithelia. Respir Res. NLM (Medline). 20: 129. URL: https://respiratory-research.biomedcentral.com/articles/10.1186/s12931-019-1101-3.

6. Barroso L, Pegram P. (2021). Clinical manifestations, diagnosis, and treatment of diphtheria - UpToDate. UpToDate. URL: https://www.uptodate.com/contents/clinical-manifestations-diagnosis-and-treatment-of-diphtheria.

7. Beigelman A, Mikols CL, Gunsten SP, Cannon CL, Brody SL, Walter MJ. (2010). Azithromycin attenuates airway inflammation in a mouse model of viral bronchiolitis. Respir Res. BioMed Central. 11: 1-11. URL: https://respiratory-research.biomedcentral.com/articles/10.1186/1465-9921-11-90.

8. Brember J, Chapman M CH et al. (2018). South Central Antimicrobial Network Guidelines for Antibiotic Prescribing in the Community. URL: http://www.nhsantibioticguidelines.org.uk/downloads/ Antibiotic_Guidelines_Final_v6b.pdf.

9. Carloan P. (2019, Feb 25). Pediatric Bronchitis: Practice Essentials, Pathophysiology, Etiology. URL: https://emedicine.medscape.com/ article/1001332-overview.

10. CDC. (2021). Diphtheria. Clinical Features. CDC. URL: https://www.cdc.gov/diphtheria/clinicians.html.

11. Coultas JA, Bodasing N, Horrocks P, Cadwgan A. (2015). Lemierre's Syndrome: Recognising a Typical Presentation of a Rare Condition. Case Rep Infect Dis. Hindawi Limited. 2015: 1-5.
12. Echeverria-Esnal D, Martin-Ontiyuelo C, Navarrete-Rouco ME, De-Antonio Cusco M, Ferrandez O, Horcajada JP et al. (2020). Azithromycin in the treatment of COVID-19: a review. Expert Rev Anti Infect Ther. Informa UK Limited: 1-17. URL: https://www.tandfonline.com/doi/full/10.1080/14787210.2020.1813024.

13. Elsevier. (2020). Azithromycin. Indications / Dosage.

14. Foong Ng K, Kee Tan K, Hong Ng B, Nair P, Ying Gan W. (2015). Epidemiology of adenovirus respiratory infections among hospitalized children in Seremban, Malaysia. Trans R Soc Trop Med Hyg. 109: 433-439. URL: http://www.ncbi.nlm.nih.gov/pubmed/26038572.

15. Gibson PG, Yang IA, Upham JW, Reynolds PN, Hodge S, James AL et al. (2017). Effect of azithromycin on asthma exacerbations and quality of life in adults with persistent uncontrolled asthma (AMAZES): a randomised, double-blind, placebo-controlled trial. Lancet. Elsevier. 390: 659-668. URL: http://www.thelancet.com/article/S0140673617312813/fulltext.

16. Giguere S, Jacks S, Roberts GD, Hernandez J, Long MT, Ellis C. (2004). Retrospective Comparison of Azithromycin, Clarithromycin, and Erythromycin for the Treatment of Foals with Rhodococcus equi Pneumonia. J Vet Intern Med. John Wiley \& Sons. 18: 568-573. URL: https://onlinelibrary.wiley.com/doi/full/10.1111/j.1939-1676.2004.tb02587.x.

17. Handy LK, Bryan M, Gerber JS, Zaoutis T, Feemster KA. (2017). Variability in Antibiotic Prescribing for Community-Acquired Pneumonia. Pediatrics: 139. URL: https://pubmed.ncbi.nlm.nih.gov/28270546/.

18. Hoffmann N, Lee B, Hentzer M, Rasmussen TB, Song Z, Johansen HK et al. (2007). Azithromycin Blocks Quorum Sensing and Alginate Polymer Formation and Increases the Sensitivity to Serum and Stationary-Growth-Phase Killing of Pseudomonas aeruginosa and Attenuates Chronic P. aeruginosa Lung Infection in Cftr-/- Mice. Antimicrob Agents Chemother. American Society for Microbiology (ASM). 51: 3677. URL: https://pmc/articles/PMC2043275/.

19. Hoshina T, Kusuhara K, Takimoto T, Saito M, Hara T. (2010). Identification of bacterial pathogens in pediatric community-acquired lower respiratory tract infection using a simplified procedure of sputum sampling and examination: comparison between hospitalized children with and without underlying diseases. Eur J Clin Microbiol Infect Dis. 29: 519-525. URL: http://www.ncbi.nlm.nih.gov/pubmed/20179982. 
20. Jain S, Williams DJ, Arnold SR, Ampofo K, Bramley AM, Reed C et al. (2015). Community-Acquired Pneumonia Requiring Hospitalization among U.S. Children. N Engl J Med. Massachusetts Medical Society. 372: 835-845. URL: https://www.nejm.org/doi/full/10.1056/ nejmoa1405870.

21. Kinkade S, Long NA. (2016). Acute Bronchitis. Am Fam Physician. 94: 560-565. URL: https://www.aafp.org/afp/2016/1001/p560.html.

22. Kliegman R, Nelson WE, Waldo E. (2011). Nelson textbook of pediatrics. Elsevier/Saunders.

23. Kronman MP, Zhou C, Mangione-Smith R. (2014). Bacterial Prevalence and Antimicrobial Prescribing Trends for Acute Respiratory Tract Infections. Pediatrics. 134: e956-965. URL: http://www.ncbi.nlm.nih.gov/pubmed/25225144.

24. Kumar P, Medigeshi GR, Mishra VS, Islam M, Randev S, Mukherjee A et al. (2017). Etiology of Acute Respiratory Infections in Infants. Pediatr Infect Dis J. 36: 25-30. URL: http://www.ncbi.nlm.nih.gov/pubmed/27753796.

25. Llor C, Moragas A, Bayona C, Morros R, Pera H, Cots JM et al. (2011). Effectiveness of anti-inflammatory treatment versus antibiotic therapy and placebo for patients with non-complicated acute bronchitis with purulent sputum. The BAAP Study protocol. BMC Pulm Med. BioMed Central. 11: 38. URL: http://www.ncbi.nlm.nih.gov/pubmed/21693045.

26. McMullan BJ, Mostaghim M. (2015). Prescribing azithromycin. Aust Prescr. Australian Government Publishing Service. 38: 87-90. URL: https://www.nps.org.au/australian-prescriber/articles/prescribingazithromycin

27. Meyer M, Huaux F, Gavilanes X, Van Den Brule S, Lebecque $P$, Lo Re $S$ et al. (2012). Azithromycin Reduces Exaggerated Cytokine Production by M1 Alveolar Macrophages in Cystic Fibrosis. American Thoracic Society. 41: 590-602. URL: www.atsjournals.org. URL: https://doi.org/101165/rcmb2008-01550C.

28. Michelow IC, Olsen K, Lozano J, Rollins NK, Duffy LB, Ziegler T et al. (2004). Epidemiology and clinical characteristics of community-acquired pneumonia in hospitalized children. Pediatrics. 113: 701-707. URL: http://www.ncbi.nlm.nih.gov/pubmed/15060215.

29. NICE. (2008). National Institute for Health and Clinical Excellence. Respiratory tract infection (self-limiting): prescribing antibiotics. NICE Guidel: 1-20. URL: www.nice.org.uk/CG69.

30. NICE. (2021). Sinusitis (acute): antimicrobial prescribing. URL: https://www.nice.org.uk/guidance/NG79.

31. Nishiyama M, Morioka I, Taniguchi-lkeda M, Mori T, Tomioka K, Nakanishi K et al. (2018). Clinical features predicting group A streptococcal pharyngitis in a Japanese paediatric primary emergency medical centre. J Int Med Res. SAGE Publications Ltd. 46: 1791-1800.

32. Oumei $\mathrm{H}$, Xuefeng $\mathrm{W}$, Jianping $\mathrm{L}$, kunling $\mathrm{S}$, Rong $\mathrm{M}$, Zhenze $\mathrm{C}$ et al. (2018). Etiology of community-acquired pneumonia in 1500 hospitalized children. J Med Virol. J Med Virol. 90: 421-428. URL: https://pubmed.ncbi.nlm.nih.gov/28975629/.

33. Park JY, Park S, Lee SH, Lee MG, Park YB, Oh KC et al. (2016). Microorganisms Causing Community-Acquired Acute Bronchitis: The Role of Bacterial Infection. Larcombe A, editor. PLoS One. Public Library of Science. 11: e0165553. URL: https://dx.plos.org/10.1371/journal.pone. 0165553

34. Qazi S, Aboubaker S, MacLean R, Fontaine O, Mantel C, Goodman T et al. (2015). Ending preventable child deaths from pneumonia and diarrhoea by 2025. Development of the integrated Global Action Plan for the Prevention and Control of Pneumonia and Diarrhoea. Arch Dis Child. 100: S23-28.

35. Reeves RM, Hardelid P, Gilbert R, Warburton F, Ellis J, Pebody RG. (2017). Estimating the burden of respiratory syncytial virus (RSV) on respiratory hospital admissions in children less than five years of age in England, 2007-2012. Influenza Other Respi Viruses. Wiley-Blackwell. 11: 122-129. URL: http://www.ncbi.nlm.nih.gov/pubmed/28058797.

36. Regoli M, Chiappini E, Bonsignori F, Galli L, De Martino M. (2011). Update on the management of acute pharyngitis in children. Ital $\mathrm{J}$ Pediatr.

37. Shimizu T, Shimizu S. (2012). Azithromycin Inhibits Mucus Hypersecretion from Airway Epithelial Cells. Mediators Inflamm. Hindawi Limited. URL: https://pmc/articles/PMC3347724/.

38. Simon HK. (2018). Pediatric Pharyngitis: Background, Pathophysiology and Etiology, Epidemiology. Medscape. URL: https://emedicine.medscape.com/article/967384-overview\#a4.

39. Skoff TH, Liang JL. (2018). Pertussis - Chapter 3 - Yellow Book. Travelers' Health. CDC. URL: https://wwwnc.cdc.gov/travel/yellowbook/2018/infectious-diseases-related-to-travel/pertussis.

40. Suttithawil W, Ploysongsang Y, Nunthapisud P, Fuangtong R. (2007). Acute primary Chlamydophila pneumoniae bronchitis and bronchial hyperresponsiveness in young nonasthmatic Thai military recruits. Ann Allergy, Asthma Immunol. 99: 413-418. URL: http://www.ncbi.nlm.nih.gov/pubmed/18051210.

41. Troeger CE, Khalil IA, Blacker BF, Biehl MH, Albertson SB, Zimsen SRM et al. (2017). Quantifying risks and interventions that have affected the burden of lower respiratory infections among children younger than 5 years: an analysis for the Global Burden of Disease Study. Lancet Infect Dis. 20: 60-79. URL: http://www.thelancet.com/ article/S1473309919304104/fulltext.

42. Ucakar V, Socan M, Trilar KP. (2013). The impact of influenza and respiratory syncytial virus on hospitalizations for lower respiratory tract infections in young children: Slovenia, 2006-2011. Influenza Other Respi Viruses. Wiley-Blackwell. 7: 1093-1102. URL: http://www.ncbi.nlm.nih.gov/pubmed/23782430.

43. Van TT, Cox LM, Cox ME, Bard JD. (2017). Prevalence of fusobacterium necrophorum in children presenting with pharyngitis. J Clin Microbiol. American Society for Microbiology. 55: 1147-1153.

44. Wald ER, Applegate KE, Bordley C, Darrow DH, Glode MP, Marcy SM et al. (2013). Clinical practice guideline for the diagnosis and management of acute bacterial sinusitis in children aged 1 to 18 years. Pediatrics. 132: e262-280. URL: http://pediatrics.aappublications.org/content/132/1/e262.abstract.

45. Wald ER, Applegate KE, Bordley C, Darrow DH, Glode MP, Marcy SM et al. (2013). Clinical practice guideline for the diagnosis and management of acute bacterial sinusitis in children aged 1 to 18 years. Pediatrics: 132.

46. Wenzel RP, Fowler AA. (2006). Acute Bronchitis. N Engl J Med. Massachusetts Medical Society. 355: 2125-2130. URL: http://www.nejm.org/doi/abs/10.1056/NEJMcp061493.

47. WHO. (2010). Macrolides (Review). World Health Organization. URL: http://www.who.int/selection_medicines/committees/subcommittee/2/macrolides/en/.

48. Wolford R, Schaefer T. (2019, Oct 22). Pharyngitis - StatPearls NCBI Bookshelf. URL: https://www.ncbi.nlm.nih.gov/ books/NBK519550/. 
49. Xu P, Zeng L, Xiong T, Choonara I, Qazi S, Zhang L. (2019). Safety of azithromycin in paediatrics: A systematic review protocol. BMJ Paediatr. Open. BMJ Publishing Group: e000469. URL: http://bmjpaedsopen.bmj.com/.

50. Yamasawa H, Oshikawa K, Ohno S, Sugiyama Y. (2012). Macrolides Inhibit Epithelial Cell-Mediated Neutrophil Survival by Modulating Granulocyte Macrophage Colony-Stimulating Factor Release. American Thoracic Society. 30: 569-575. URL: www.atsjournals.org. URL: https://doi.org/101165/rcmb2003-01050C.

51. Yang J. (2020). Mechanism of azithromycin in airway diseases. J Int Med Res. SAGE Publications Ltd: 48. URL: https://journals.sagepub.com/doi/full/10.1177/0300060520932104.
52. Zeng L, Xu P, Choonara I, Bo Z, Pan X, Li W et al. (2020). Safety of azithromycin in pediatrics: a systematic review and meta-analysis. Eur J Clin Pharmacol. Springer Science and Business Media Deutschland GmbH. 76: 1709-1721. URL: https://link.springer.com/article/10.1007/s00228-020-02956-3.

53. Zupanets I, Bezuglaya N, Libina V, Orlova I, Kudris I, Kuvayskov Yu. (2013). Otsenka vzaimozamenyaemosti Azimeda bioekvivalentnost dokazana! Liki Ukrayini. 1: 80-83. [Зупанец И, Безуглая Н, Либина В, Орлова И, Кудрис И, Кувайсков Ю. (2013). Оценка взаимозаменяемости Азимеда - биоэквивалентность доказана! Ліки України. 1: 80-83].

\section{Відомості про авторів:}

Крамарьов Сергій Олександрович - Засл. лікар Укрӓни, дмед.н., проф., зав. каф. дитячих інфекційних хвороб НмУ імені О.О. Богомольця. Адреса: м. Київ, вул. Дегтярівська, 23; тел.: (044) 483-74-62.

Євтушенко Віталій Вячеславович - к.мед.н, доц. каф. дитячих інфекційних хвороб НМУ імені О.О. Богомольця. Адреса: м. Київ, вул. Дегтярівська, 23; тел.: (044) 483-74-62.

Стаття надійшла до редакції 06.09.2021р., прийнята до друку 09.11.2021 р.

\section{ДО УВАГИ АВТОРІВ!}

\section{AJITOPUITM PECCTPAIIII ORCID}

\section{Open Researcher and Contributor ID (ORCID) - міжнародний ідентифікатор науковця}

Створення єдиного реєстру науковців та дослідників на міжнародному рівні є найбільш прогресивною та своєчасною ініціативою світового наукового товариства. Ця ініціатива була реалізована через створення в 2012 році проекту Open Researcher and Contributor ID (ORCID). ORCID - це реєстр унікальних ідентифікаторів вчених та дослідників, авторів наукових праць та наукових організацій, який забезпечує ефективний зв'язок між науковцями та результатами їх дослідницької діяльності, вирішуючи при цьому проблему отримання повної і достовірної інформації про особу вченого в науковій комунікації.

Для того щоб зареєструватися в ORCID через посилання https://orcid.org/ необхідно зайти у розділ «For researchers» i там натиснути на посилання «Register for an ORCID iD».

В реєстраційній формі послідовно заповнюються обов'язкові поля: «First name», «Last name», «E-mail», «Re-enter E-mail», «Password» (Пароль), «Confirm password»

В перше поле вводиться ім'я, яке надане при народженні, по-батькові не вводиться. Персональна електронна адреса вводиться двічі для підтвердження. Вона буде використовуватися як Login або ім'я користувача. Якщо раніше вже була використана електронна адреса, яка пропонується для реєстрації, з'явиться попередження червоного кольору. Неможливе створення нового профілю з тією ж самою електронною адресою. Пароль повинен мати не менше 8 знаків, при цьому містити як цифри, так і літери або символи. Пароль, який визначається словами «Good» або «Strong» приймається системою..

Нижче визначається «Default privacy for new works», тобто налаштування конфіденційності або доступності до персональних даних, серед яких «Public», «Limited», «Private».

Далі визначається частота повідомлень, які надсилає ORCID на персональну електронну адресу, а саме, новини або подіï, які можуть представляти інтерес, зміни в обліковому записі, тощо: «Daily summery», «Weekly summery», «Quaterly summery», «Never». Необхідно поставити позначку в полі «I'm not a robot» (Я не робот).

Останньою дією процесу реєстрації є узгодження з політикою конфіденційності та умовами користування. Для реєстрації необхідно прийняти умови використання, натиснувши на позначку «I consent to the privacy policy and conditions of use, including public access and use of all my data that are marked Public».

Заповнивши поля реєстраційної форми, необхідно натиснути кнопку «Register», після цього відкривається сторінка профілю учасника в ORCID з особистим ідентифікатором ORCID ID. Номер ORCID ідентифікатора знаходиться в лівій панелі під ім'ям учасника ORCID.

Структура ідентифікатора ORCID являє собою номер з 16 цифр. Ідентифікатор ORCID - це URL, томy запис виглядає як http://orcid.org/xxxx-xxxx-xxxxxxxx.

Наприклад: http://orcid.org/0000-0001-7855-1679.

Інформацію про ідентифікатор ORCID необхідно додавати при подачі публікацій, документів на гранти і в інших науково-дослідницьких процесах, вносити його в різні пошукові системи, наукометричні бази даних та соціальні мережі.

Подальша робота в ORCID полягає в заповненні персонального профілю згідно із інформацією, яку необхідно надавати. 



\title{
Ю.В. Марушко, С.І. Єсипова, Т.В. Гищак Вплив забезпечення вітаміном D на перебіг гострих респіраторних інфекцій у дітей
}

\author{
Національний медичний університет імені О.О. Богомольця, м. Київ, Україна \\ Modern Pediatrics. Ukraine. (2021). 7(119): 73-80. doi 10.15574/SP.2021.119.73 \\ For citation: Marushko YuV, Esipova SI, Gishchak TV. (2021). Influence of vitamin D provision on the course of acute respiratory infections in children
} Modern Pediatrics. Ukraine. 7(119): 73-80. doi 10.15574/SP.2021.119.73.

\begin{abstract}
В оглядовій статті наведено дані сучасних досліджень, що підтверджують багатогранну дію вітаміну D в організмі людини. Доведено, що рецептори до вітаміну $\mathrm{D}_{3}(\mathrm{VDR})$ наявні в більшості органів та тканин організму. Це підтверджує значення вітаміну D не тільки в процесах формування кісткової системи, але й у багатьох його позакісткових ефектах. Кальцитріол впливає на модуляцію клітинного росту, нервово-м'язову провідність, процеси запалення, а також $є$ важливим стимулятором вродженого імунітету завдяки синтезу антимікробних пептидів, які забезпечують захист проти бактерій та вірусів. Останніми роками активно вивчають зв'язок між концентрацією вітаміну D в крові та рівнем захворюваності на респіраторні інфекції в дітей. У багатьох дослідженнях доведено, що низький статус вітаміну D характерний для більшості дітей з респіраторними інфекціями, а адекватний рівень 25(OH)D у сироватці крові має позитивний вплив на частоту виникнення цих інфекцій та тяжкість їх перебігу. Більшість авторів показують переваги додавання вітаміну D у профілактиці респіраторних захворювань у дітей, однак немає одностайної думки щодо частоти призначення та дозування вітаміну D.
\end{abstract}

Автори заявляють про відсутність конфрлікту інтересів.

Ключові слова: вітамін D, діти, десріцит, респіраторні захворювання, профрілактика.

\section{Influence of vitamin D provision on the course of acute respiratory infections in children Yu.V. Marushko, S.I. Esipova, T.V. Gishchak \\ Bogomolets National Medical University, Kyiv, Ukraine}

The review article provides data from modern studies confirming the multifaceted effect of vitamin D in the human body. Vitamin Dz receptors (VDRs) have been shown to be present in most organs and tissues of the body. This confirms the importance of vitamin D not only in the formation of the skeletal system, but also in many of its extraosseous effects. Calcitriol affects the modulation of cell growth, neuromuscular conduction, inflammation processes, and is also an important stimulator of innate immunity due to the synthesis of antimicrobial peptides that provide protection against bacteria and viruses.

In recent years, the relationship between the concentration of vitamin $D$ in the blood and the incidence of respiratory infections in children has been actively studied. Many studies have shown that low vitamin $\mathrm{D}$ status is characteristic of most children with respiratory infections, and an adequate level of $25(\mathrm{OH}) \mathrm{D}$ in serum has a positive effect on the frequency of these infections and the severity of their course. Most authors demonstrate the benefits of vitamin D supplementation in the prevention of respiratory diseases in children, but there is no consensus regarding the frequency and dosage of vitamin $\mathrm{D}$.

The authors declare that they have no conflicts of interest.

Key words: vitamin D, children, deficiency, respiratory diseases, prevention.

\section{Влияние обеспеченности витамином D на течение острых респираторных инфекций у детей Ю.В. Марушко, С.И. Есипова, Т.В. Гищак \\ Национальный медицинский университет имени А.А. Богомольца, г. Киев, Украина}

B обзорной статье приведены данные современных исследований, подтверждающих многогранное действие витамина D в организме человека. Доказано, что рецепторы к витамину $\mathrm{D}_{3}(\mathrm{VDR})$ присутствуют в большинстве органов и тканей организма. Это подтверждает значение витамина D не только в процессах формирования костной системы, но и во многих его внекостных эффекктах. Кальцитриол влияет на модуляцию клеточного роста, нервно-мышечную проводимость, процессы воспаления, а также является важным стимулятором врожденного иммунитета благодаря синтезу антимикробных пептидов, обеспечивающих защиту против бактерий и вирусов. В последние годы активно изучается связь между концентрацией витамина D в крови и уровнем заболеваемости респираторными инфекциями у детей. Во многих исследованиях доказано, что низкий статус витамина D характерен для большинства детей с респираторными инсекциями, а адекватный уровень 25(OH)D в сыворотке крови оказывает положительное влияние на частоту этих инсрекций и тяжесть их течения. Большинство авторов демонстрируют преимущества добавления витамина $D$ B профилактике респираторных заболеваний у детей, однако нет единого мнения относительно частоты назначения и дозировки витамина D.

Авторы заявляют об отсутствии конфрликта интересов.

Ключевые слова: витамин D, дети, десицит, респираторные заболевания, просилактика.

$\mathrm{B}$ ітамін D є найпопулярнішим вітаміном сьогодення завдяки стрімкому зростанню кількості наукових досліджень, які доводять його різноспрямовану активність в організмі. Важлива роль вітаміну D полягає в регуляції кальцій-фосфорного обміну та кісткового метаболізму. Вітамін D сприяє абсорбції кальцію в кишечнику та підтримує необхідні рівні кальцію та фосфатів у крові для забезпечення мінералізації кісткової тканини. Достатній рівень вітаміну D забезпечує зростання кісток i процес кісткового ремоделювання та запобігає розвитку рахіту, гіпокальціємічній тетанії в дітей та остеомаляції в дорослих [12,15,22].

Завдяки науковим дослідженням останніх років відбувається еволюція наших поглядів на роль вітаміну D в організмі людини. Кальцитріол $\left(1,25(\mathrm{OH})_{2} \mathrm{D}\right)$ є стероїдним гормоном і виконує 
свою біологічну дію після зв'язування зі специфічними рецепторами-мішенями. На сьогодні доведено, що мішенями активних метаболітів вітаміну D $є$ рецептори вітаміну $\mathrm{D}_{3}$ (VDR vitamin D receptor), наявні в понад 38 органах та тканинах організму (кишечник, нирки, кістки, імунні клітини, шкіра, серце та мозок), що підтверджує наявність у вітаміну D великої кількості біологічних функцій $[30,49]$.

Отже, значення вітаміну D для організму людини полягає не тільки в його впливі на процеси формування кісткової системи, але й у багатьох позакісткових ефектах холекальциферолу. Він також впливає на фізіологічні процеси в організмі, що включають модуляцію клітинного росту, нервово-м'язову провідність, імунітет і запалення [6,8,12,23,31]. Експресія багатьох генів, що беруть участь у проліферації, диференціюванні та апоптозі, регулюється вітаміном D $[6,8,12]$. Вітамін D $є$ важливим стимулятором вродженого імунітету - кальци- тріол посилює протимікробну дію макрофагів і моноцитів, підвищує хемотаксис і фагоцитарну функцію імунних клітин $[14,49]$.

Mema дослідження - узагальнити дані літератури щодо забезпечення вітаміном D населення та щодо впливу вмісту вітаміну D на перебіг гострих респіраторних інфекцій (ГРІ) у дітей.

Проблема дефіциту вітаміну D є однією з актуальних, його недостатність зареєстрована в половини населення світу та за даними Всесвітньої організації охорони здоров'я має характер пандемії $[4,23,36]$. У ряді країн питання недостатності вітаміну D розглядають як один із напрямів національної політики у сфері захисту здоров'я громадян [40].

У рамках епідеміологічних досліджень дефіциту та недостатності вітаміну D у населення України, проведених у 2011-2014 рр. [45], обстежено 1575 практично здорових дорослих та 300 дітей віком 10-17 років. За підсумками

Поширеність та фактори ризику дефіциту вітаміну D у педіатричних групах населення у світі*

Таблиия

\begin{tabular}{|c|c|c|c|}
\hline Дослідження & Популяція & $\begin{array}{c}\text { Поширеність дефіциту } \\
\text { вітаміну D }\end{array}$ & $\begin{array}{c}\text { Виявлені фактори ризику } \\
\text { дефріциту вітаміну D }\end{array}$ \\
\hline Gordon et al., 2014 [13] & $\begin{array}{c}307 \text { підлітків 11-18 років } \\
\text { у Бостоні, Массачусетс, США }\end{array}$ & $\begin{aligned} & \leq 20 \text { нмоль/л: } 4,6 \% \\
\leq 37,5 \text { нмоль/л: } 24,1 \% & \\
& \leq 50 \text { нмоль/л: } 42 \%\end{aligned}$ & $\begin{array}{l}\text { Сезон, національність, недостатне } \\
\text { споживання молока та соку, } \\
\text { низький індекс маси тіла, низька } \\
\text { фізична активність }\end{array}$ \\
\hline Marwaha et al., 2015 [14] & $\begin{array}{c}5137 \text { підлітків 10-18 років } \\
\text { у Нью-Делі, Індія }\end{array}$ & $<22,5$ нмоль/л: $35,7 \%$ & $\begin{array}{l}\text { Низький соціально-економічний } \\
\text { статус, жіноча стать }\end{array}$ \\
\hline Kumar et al., 2009 [15] & $\begin{array}{l}6275 \text { пацієнтів 1-21 року } \\
\text { у США, 2001-2004рр. }\end{array}$ & $\begin{array}{l}<37,5 \text { нмоль/л: } 9 \% \\
<72,5 \text { нмоль/л: } 70 \%\end{array}$ & $\begin{array}{l}\text { Жіноча стать, темна шкіра, } \\
\text { ожиріння, молоко <1 раз на } \\
\text { тиждень }\end{array}$ \\
\hline Rabenberg et al., 2018 [16] & $\begin{array}{l}10015 \text { дітей 1-17 років } \\
\text { у Німеччині, 2003-2006 рр. }\end{array}$ & $\begin{array}{c}\text { <30 нмоль/л: 12,5\% в обох } \\
\text { групах хлопців і дівчат. Від } 30 \\
\text { до <50 нмоль/л: 32,7\% у } \\
\text { хлопчиків і 33,5\% у дівчат }\end{array}$ & $\begin{array}{l}\text { Найбільша поширеність дефріциту } \\
\text { в дівчат віком } 11-13 \text { років (18,9\%) } \\
\text { і найменша поширеність дефріциту } \\
\text { у хлопчиків віком } 1-2 \text { років }(4,9 \%)\end{array}$ \\
\hline $\begin{array}{l}\text { Public Health England, } \\
\text { Food Standards Agency. } \\
\text { National Diet and Nutrition } \\
\text { Survey, } 2018 \text { [18] }\end{array}$ & $\begin{array}{c}902 \text { дитини у Великій Британії, } \\
\text { 2008-2011рр. }\end{array}$ & $\begin{array}{c}<25 \text { нмоль/л: 8\% дітей } \\
\text { 1,5-3 роки, } 12 \% \text { хлопчиків } \\
4-10 \text { років, } 16 \% \text { дівчат } \\
\text { 4-10 років, 20\% хлопчиків } \\
11-18 \text { років, 24\% дівчат } \\
11-18 \text { років }\end{array}$ & Не надається \\
\hline Maguire et al., 2013 [13] & $\begin{array}{l}1898 \text { дітей 1-5 років } \\
\text { у Торонто, Канада }\end{array}$ & $\begin{array}{l}<50 \text { нмоль/л: } 6 \% \\
<75 \text { нмоль/л: } 35 \%\end{array}$ & $\begin{array}{l}\text { Без споживання вітаміну D } \\
\text { та коров'ячого молока, зимовий } \\
\text { сезон, темна пігментація шкіри }\end{array}$ \\
\hline Garg et al., 2014 [13] & $\begin{array}{c}1829 \text { підлітків } \\
\text { у Нью-Делі, Індія }\end{array}$ & $\begin{array}{l}\text { <12,5 нмоль/л: } 28 \% \\
<25 \text { нмоль/л: } 71 \% \\
<50 \text { нмоль/л: } 97 \%\end{array}$ & Не надається \\
\hline Angurana et al., 2014 [13] & $\begin{array}{c}388 \text { дітей } \\
3 \text { міс - } 12 \text { років } \\
\text { у Чандігарх, Індія }\end{array}$ & $\begin{array}{l}<50 \text { нмоль/л: } 40 \% \\
<75 \text { нмоль/л: } 66 \%\end{array}$ & $\begin{array}{l}\text { Молодший вік, жіноча, стать, } \\
\text { виключно грудне вигодовування, } \\
\text { недостатня сонячна експозиція, } \\
\text { відсутність добавок вітаміну D }\end{array}$ \\
\hline Cairncross et al., 2017 [13] & $\begin{array}{c}1329 \text { дітей 2-5 років } \\
\text { у Новій Зеландії }\end{array}$ & $\begin{array}{l}<25 \text { нмоль/л: } 7 \% \\
<50 \text { нмоль/л: 48\% } \\
<75 \text { нмоль/л: } 89 \%\end{array}$ & $\begin{array}{l}\text { Жіноча стать, темний колір шкіри, } \\
\text { відсутність добавки вітаміну D, } \\
\text { матері з освітою нижче середньої, } \\
\text { райони проживання низького } \\
\text { економічного рівня }\end{array}$ \\
\hline
\end{tabular}

Примітка: за даними S.N. Taylor, 2020 [50]. 
дослідження, нормальний рівень вітаміну D визначено лише у 4,6\% учасників, а недостатність і дефіцит - у 13,6\% і 81,8\% відповідно. Ще більш тривожну ситуацію виявлено в дітей віком 10-18 років: нормальний вміст вітаміну D зареєстровано лише в $1,4 \%$ обстежених, у 92,2\% відмічено виражений його дефіцит.

Результати масштабних популяційних досліджень дефіциту й недостатності вітаміну D y світі наведено в таблиці, що демонструє спільні та відмінні тенденції залежно від країни, вікової групи та часу проведення досліджень.

Особливе значення вітамін D має у виникненні та перебігу ГРІ. Відомо, що вітамін D бере активну участь у синтезі антимікробних пептидів (АМП), які мають прямі протимікробні ефекти та є ключовими компонентами вродженого імунітету. АМП виступають як «імунні регулятори» і відкривають значні перспективи для розроблення нових стратегій у боротьбі 3 інфекційними захворюваннями [14,55].

Антимікробні ефекти вітаміну D вивчено в ряді досліджень. Так, у дітей з дефіцитом вітаміну D встановлено бактеріальну колонізацію верхніх дихальних шляхів бактеріальними патогенами [24]. Відзначено високий рівень поширеності гіповітамінозу D у дітей при сепсисі $[9,44]$. При гіповітамінозі D у дітей констатовано колонізацію шкіри золотистим стафілококом [53]. Значна кількість наукових праць констатує зв'язок рівнів вітаміну D y дітей із частотою та тяжкістю ГРІ [25,28], пневмонії [11] та отиту [10].

Є дослідження, що доводять зв'язок дефіциту вітаміну D з рецидивним перебігом інфекцій: ГРІ [33], тонзиліту [13] і бронхіту [51]. Лише в поодиноких дослідженнях заперечується зв'язок вітаміну D у дітей з тяжкістю пневмонії [21] та отиту [5]. На особливу увагу заслуговують результати досліджень про високу кореляцію гіповітамінозу D у дітей з туберкульозною інфекцією $[7,19,37]$. Дослідження серед дітей з інфекціями нижніх дихальних шляхів (ІНДШ) показують взаємозв'язок між низьким рівнем вітаміну D і вищим ризиком ІНДШ (пневмонії та бронхіоліти) у дітей в Індії [27], Непалі [21] та Індонезії [41].

У метааналізі австралійських учених [43] встановлено, що концентрація 25(OH)D y сироватці має зворотний пропорційний зв'язок з ризиком розвитку та тяжкістю ГРІ; об'єднані відношення шансів (95\% довірчий інтервал) становили $1,83(1,42-2,37)$ та $2,46(1,65-3,66)$ відповідно. На кожні 10 нмоль/л зниження концентрації 25(OH)D ймовірність ГРI збільшувалася на 1,02 (0,97-1,07), причому найбільш значне підвищення ризику розвитку ГРI відмічалося при концентрації 25(OH)D $<37,5$ нмоль/л.

В одному з досліджень вивчено зв'язки рівнів вітаміну D з наявністю певного вірусу в дітей 12-60 місяців із рекурентними респіраторними захворюваннями. Порівняно 3 контрольною групою в дітей з рекурентними ГРІ рівень вітаміну D був значно нижчим ( $<15 \mathrm{ng} / \mathrm{mL})$, і саме в цій групі найчастіше виявлявся риновірус (63,2\%). Однак статистично значущої різниці між виявленням вірусу та рівнем вітаміну D не було [16].

Когортне дослідження корейських вчених [48] спрямовано на вивчення зв'язку між концентрацією 25(OH)D у пуповинній крові та подальшим ризиком розвитку ГРІ у немовлят протягом перших 6 місяців життя. Серед 525 корейських новонароджених 34,3\% мали концентрації 25(OH)D <25,0 нмоль/л. Саме в групі немовлят із дефіцитом 25(OH)D ймовірність розвитку гострого ринофарингіту виявилася вищою ( $\mathrm{p}=0,0004)$. Не було відмінностей у поширеності середнього отиту або бронхіоліту залежно від концентрації 25(OH)D пуповинної крові ( $\mathrm{p}=0,4554$ i $\mathrm{p}=0,3718$ відповідно). Однак виявлено, що в немовлят із дефіцитом вітаміну D імовірність розвитку будь-якої ГРІ (гострий назофарингіт, середній отит і бронхіоліт) протягом перших 6 місяців життя в 3,56 раза була вищою ( $\mathrm{p}=0,0015)$ порівняно 3 дітьми 3 нормальним рівнем вітаміну D в організмі [48].

Рандомізоване контрольоване дослідження за участю 960 дітей віком 6-30 місяців виявило значний ефект оптимального статусу вітаміну D у дітей, що полягає в зниженні частоти розвитку ІНДШ [11]. Серед обстежених дітей 34,5\% мали дефіцит вітаміну $\mathrm{D}$, який оцінювали за рівнем $<10$ нг/мл. Автори виявили, що ризик ГРІ був значно вищим у групі дітей з дефіцитом вітаміну D (OR: 1,26; 95\% CI: 1,03-1,55) порівняно 3 дітьми 3 нормальним рівнем. Але з епізодами клінічної пневмонії статус вітаміну D не був пов'язаний. Тобто, за даними цього дослідження, дефіцит вітаміну D $(<10$ нг/мл) можна вважати предиктором виникнення ГРІ в дітей.

A. Jolliffe et al. [30] вивчали питання застосування вітаміну D для профілактики респіраторних інфекцій. Автори виявили, що в людей 3 вихідною концентрацією 25(OH)D у крові 
$<25$ нмоль/л ризик розвитку респіраторної інфекції був вищим. Крім того, ризик був нижчим у дослідженнях, де вітамін D вводили щодня або щотижня, а не одноразово у великих дозах [30].

До нового систематичного огляду A. Jolliffe et al. (2020) увійшло 1528 статей, з яких 43 дослідження включали дані про розвиток інфекції на тлі застосування вітаміну D [29]. Загальна вибірка становила 48488 осіб віком від народження до 95 років. Порівняно з учасниками групи плацебо, суб'єкти, які застосовували вітамін D, не показували значного зниження ризику розвитку ГРІ незалежно від вихідної концентрації 25(OH)D у крові (61,3\% проти $62,3 \%)$. Однак статистично значущий захисний ефект вітаміну D спостерігався в дітей віком від 1 до 15,9 року (OR: 0,71; 95\% CI: від 0,57 до $0)$, відзначалося зниження ризику розвитку одного або декількох ГРІ при застосуванні вітаміну D.

Щодо частоти дозування, то, за даними вищевказаних авторів, захисний ефект спостерігався в дослідженнях, де вітамін D призначали щодня (OR: 0,75; 95\% CI: від 0,61 до 0,93). У разі вживання вітаміну D 1 раз на тиждень, одноразовому введенні великих доз щомісяця або 1 раз на 3 місяці протективних ефектів не спостерігалося. Значні захисні ефекти відмічалися в дослідженнях, у яких вітамін D вводили в добовій дозі 400-1000 МО та у дослідженнях, у яких учасники застосовували вітамін D протягом року або менше. Однак аналіз показав, що в людей з астмою та хронічною обструктивною хворобою легень вітамін D не знижував ризиків розвитку захворювання.

У 2017 р. наведено дані масштабного метааналізу 25 рандомізованих контрольованих досліджень за участю 10933 осіб віком від 0 до 95 років [35]. Метою роботи стала оцінка взаємозв'язку між застосуванням вітаміну D i частотою розвитку ГРІ. Використовували режими дозування - щодня, щотижня або принаймні одну болюсну дозу не менше 30000 МО вітаміну D, розмір дози - добовий еквівалент $<800$ МО, 800-1999 МО, $\geq 2000$ МО. Болюсну дозу вводили щомісяця або кожні три місяці в 7 дослідженнях, щотижневу дозу у 3 дослідженнях, добову дозу - у 12. Встановлено, що на тлі додавання нутрієнта до схеми профілактики ризик розвитку хоча б одного випадку ГРI зменшувався: 40,3\% порівняно з 42,2\% у групі плацебо (OR: 0,88; 95\% CI: 0,81-0,96). При цьому більш виражене зниження спостерігало- ся в підгрупах пацієнтів, які отримували вітамін D щодня або щотижня без додаткового болюсного введення. Також відзначено, що більш значуща профілактична дія вітаміну D спостерігалася серед пацієнтів, які мали низький рівень 25-гідроксикальциферолу $(<25$ нмоль/л): ризик розвитку хоча б одного епізоду ГРІ знижувався - 47,6\% проти 43,1\% у підгрупі з нормальним рівнем 25-гідроксикальциферолу (OR: 0,8; 95\% CI: 0,68-0,94). Серед вікових груп значний ефект виявлено в дітей 1-16 років - ризик захворюваності знизився 3 47\% (група плацебо) до 34,3\% (група 3 дотацією вітаміном D). У групі дітей до 1 року такий ефект не спостерігався [35].

В іншому дослідженні не було різниці в кількості лабораторно підтверджених вірусних інфекцій верхніх дихальних шляхів у здорових дітей віком від 1 до 5 років, які отримують 2000 одиниць вітаміну D проти 400 міжнародних одиниць вітаміну D щодня [1]. Ці дані не підтверджують використання високих доз вітаміну D для профілактики вірусних інфекцій верхніх дихальних шляхів.

Yakoob et al. (2016) провели Кокранівський огляд 4 досліджень за участю 3198 дітей 3 Афганістану, Іспанії та США [54]. Оцінювали пероральне застосування вітаміну D та рівень захворюваності на інфекції дихальних шляхів (зокрема, на пневмонію) у дітей віком до 5 років. Цей огляд включав дослідження добавок вітаміну D у різних дозах і з різною частотою порівняно з контрольною групою. Епізоди пневмонії були схожими між групами, які отримували вітамін D, порівняно 3 контрольною групою (коефіцієнт захворюваності: 1,06; 95\% CI: 0,89-1,26). Тобто дослідження не показали переваги добавок вітаміну D щодо захворюваності на пневмонію в дітей віком до 5 років.

Отже, більшість авторів одностайні, що низький статус вітаміну D характерний для більшості дітей з ГРІ. Крім того, показано, що адекватний рівень 25(OH)D у сироватці крові надає позитивний вплив на частоту виникнення цих інфекцій. Однак дослідження з додаванням вітаміну D мали суперечливі результати щодо частоти призначення та дозування вітаміну D.

У ряді досліджень показано негативну кореляційну залежність між рівнем вітаміну D i тяжкістю ГРІ, яка визначалася тривалістю захворювання, госпіталізацією та ступенем тяжкості [18,26,38,41].

Мак Наллі та його колеги обстежили 105 дітей віком до 5 років з ГРІ (бронхіоліт та пне- 
вмонія), які потребували госпіталізації. Середній рівень $25(\mathrm{OH})$ D був значно нижчим у 16 дітей з ГРІ, які потребували госпіталізації до відділення інтенсивної терапії (15\%), ніж у контрольних суб'єктів та дітей у загальному педіатричному відділенні. Автори дійшли висновку, що недостатній статус вітаміну D може впливати на тяжкість ГPI, але не на ризик госпіталізації [38].

У дослідженні японських авторів [26] вивчено зв'язок між дефіцитом вітаміну D і тяжкістю респіраторної інфекції шляхом визначення сироваткових концентрацій 25(OH)D у групі госпіталізованих дітей з ІНДШ. Серед 28 дітей, які взяли участь у дослідженні, у 26 дітей діагностували бронхіоліт, а у 2 дітей - пневмонію. Виявилася значна кореляція між дефіцитом вітаміну D (<15 нг/мл) та потребою в додатковому кисні та штучній вентиляції легень.

У недавньому дослідженні ізраїльських вчених [18] оцінено рівень вітаміну D у сироватці крові немовлят і дітей раннього віку з гострим бронхіолітом порівняно з суб'єктами з нереспіраторними фебрильними станами. Обстежено дітей віком до 24 місяців, направлених до відділення невідкладної допомоги з фебрильними захворюваннями (температура $>38,5^{\circ} \mathrm{C}$, тривалість $->24$ год), серед яких виділяли дві групи діти з бронхіолітом (основна група) та без респіраторних симптомів (контрольна група). У ході дослідження оцінено ступінь тяжкості бронхіоліту за допомогою модифікованої шкали Тала (MTS), а також тривалість перебування у стаціонарі та потребу в штучній вентиляції легень.

Рівень вітаміну D у сироватці крові був значно нижчим у групі з бронхіолітом. Тобто результати показали, що дефіцит вітаміну D був пов'язаний з гострим бронхіолітом порівняно з фебрильними нереспіраторними захворюваннями. У цьому дослідженні не доведено кореляції між рівнем вітаміну D і ступенем тяжкості бронхіоліту [18].

У дослідженні Vicka Oktaria et al. [41] визначено поширеність дефіциту вітаміну D в індонезійських дітей, госпіталізованих із пневмонією, оцінено зв'язок між статусом вітаміну D й тяжкістю пневмонії. Обстежено 133 дітей віком 2-59 місяців із пневмонією, тяжкість якої вивчено за показниками гіпоксемії, тривалості лікування та перебування у відділенні інтенсивної терапії. Середня концентрація вітаміну D становила 67 ( $\pm 24 \mathrm{SD})$ нмоль/л, у 19\% дітей виявлено дефіцит вітаміну D. Тобто кожна п'ята дитина, госпіталізована 3 пневмонією, мала дефіцит вітаміну D. Однак статус вітаміну D не був пов'язаний з тяжкістю пневмонії [41].

Водночас в інших дослідженнях повідомлялося, що дефіцит вітаміну D був значно пов'язаний $з$ вищою ймовірністю госпіталізації до відділення інтенсивної терапії, неефективного лікування або тривалішого перебування в лікарні [9,21,39,52].

У дослідженні Johanne Haugen et al. [21] дефіцит вітаміну D ( $<50$ нмоль/л) виявлено у 11,8\% дітей з ІНДШ. Причому доведено, що такий дефіцит пов'язаний з підвищеним ризиком неефективного лікування та збільшенням часу для одужання. Саме цей рівень вітаміну D корелював 3 відсутністю клінічного поліпшення в пацієнтів протягом 96 год. За даними дослідження, низький статус вітаміну $\mathrm{D}(25(\mathrm{OH}) \mathrm{D}<50$ нмоль/л) є незалежним фактором ризику неефективності лікування та уповільнення темпів одужання після тяжких інфекцій нижніх дихальних шляхів у дітей [21].

Проспективне когортне дослідження проведено в 17 центрах (1016 немовлят), серед дітей з бронхіолітом показало, що в дітей із загальним рівнем 25(OH)D $<20$ нг/мл був підвищений ризик госпіталізації до відділення інтенсивної терапії та довша тривалість перебування у стаціонарі [52].

Зв'язок статусу вітаміну D зі смертністю серед дітей з тяжким перебігом IНДШ вивчено в метааналізі 7434 педіатричних пацієнтів [9]. У дослідженні виявлено високі рівні дефіциту вітаміну D у групі загалом і вищі рівні (64\%) у дітей із сепсисом. Більш того, дефіцит вітаміну D був пов'язаний із підвищеною смертністю. Ці результати узгоджуються з даними метааналізу, проведеного групою канадських вчених [39] для оцінки поширеності дефіциту вітаміну D у педіатричному відділенні інтенсивної терапії та його зв'язку з клінічними наслідками критичних станів. У ході метааналізу виявлено, що більш ніж у половини дітей з критичними станами на момент госпіталізації до відділення інтенсивної терапії спостерігався дефіцит вітаміну D, який визначався як загальна концентрація $25(\mathrm{OH}) \mathrm{D}$ у крові $<50$ нмоль/л. Також визначено, що дефіцит вітаміну D корелював із більш вираженою тяжкістю перебігу захворювання, високим ризиком розвитку поліорганної дисфункції та смертності в умовах інтенсивної терапії [39].

Систематичний огляд і метааналіз 12 досліджень показав, що діти з ІНДШ мали значно 
нижчі середні рівні вітаміну $\mathrm{D}$, ніж здорові діти. А рівень вітаміну D в крові прямо корелював із частотою рецидивів і тяжкістю перебігу ІНДШ [28].

Отже, переважна більшість досліджень підтверджують, що дефіцит вітаміну D поширений серед пацієнтів із тяжким перебігом ГРI і може бути фактором ризику більшої тяжкості перебігу та несприятливих наслідків при критичних станах. Водночас необхідні подальші клінічні дослідження, щоб визначити, чи покращує оптимізація статусу вітаміну D результат лікування пацієнтів.

Існує чимало клінічних звітів, у яких наведено докази зв'язку між статусом вітаміну D та COVID-19, але всі вони засновані на ретроспективних даних. Більшість цих досліджень припускають зв'язок між дефіцитом вітаміну D і підвищеною сприйнятливістю до інфекції SARS-CoV-2, при цьому наголошуючи на важливість відновлення нормального рівня вітаміну D $[2,17,20]$.

Також проаналізовано зв'язок між дефіцитом вітаміну D i тяжкістю інфекції COVID-19. У ретроспективному багатоцентровому дослідженні виявлено, що дефіцит вітаміну D $(<20 \mathrm{ng} / \mathrm{ml})$ відмічався у 36,3\% дорослих пацієнтів із тяжким клінічним перебігом інфекції COVID-19 [3].

У метааналізі Marcos Pereira (2020) визначено, що в пацієнтів із тяжкими випадками COVID-19 на 64\% частіше зустрічається дефіцит вітаміну D порівняно з легкими випадками (OR: 1,64; 95\% CI: 1,30-2,09). Недостатність вітаміну D збільшує госпіталізацію (OR: 1,81, 95\% CI: 1,41-2,21) і смертність від COVID-19 (OR: 1,82, 95\% CI: 1,06-2,58). Дефіцит вітаміну $\mathrm{D}$ не пов'язаний з більш високою ймовірністю зараження COVID-19 (OR: 1,35; 95\% CI: 0,80-1,88) [42].

В огляді Роудса та його колег підтверджено позитивний зв'язок між дефіцитом вітаміну D і тяжкістю захворювання [46]. Іншими дослідниками виявлено дефіцит вітаміну D у 84,6\% пацієнтів з інфекцією COVID-19 у відділеннях інтенсивної терапії закладу третинної медичної допомоги в Новому Орлеані, США [32]. Смертність від COVID-19 значною мірою пов'язана зі статусом вітаміну D у різних популяціях Європейських країн [47,34].

Отже, можна констатувати суттєву поширеність недостатності та дефіциту вітаміну D у педіатричній популяції у всьому світі. Водночас актуальним залишається питання вивчення причин формування когорти дітей з частими епізодами ГРІ та їх профілактики. Серед причин частих ГРІ багато авторів звертають увагу на дефіцит вітаміну D.

Хоча механізм впливу вітаміну D на імунітет досить складний, існуючі дані підтверджують, що адекватний рівень 25(OH)D у крові сприяє оптимізації захисних функцій імунних клітин під впливом бактеріальних і вірусних інфекцій. Більшість досліджень доводять, що знижені концентрації 25(OH)D у сироватці переважають серед дітей з ГРI, а дефіцит вітаміну D пов'язаний з підвищеним ризиком їх розвитку.

Серед зареєстрованих в Україні різних форм випуску вітаміну D, що використовується в клінічній практиці, є препарат Відеїн по 500 і 1000 МО у м'яких капсулах. В якості допоміжних речовин до препарату входять $\alpha$-токоферолу ацетат і тригліцериди середнього ланцюга, що поліпшують засвоєння вітаміну $\mathrm{D}$ та знижують вірогідність токсичних ефектів. Оригінальна форма капсул (у вигляді «рибки» i «пляшечки») і можливість розкриття капсули з додаванням її вмісту до їжі робить препарат зручним для застосування в дітей.

Дані більшості авторів свідчать про позитивний протективний вплив адекватного статусу вітаміну D на частоту й тяжкість інфекцій, що може бути ефективним і невисоковартісним способом профілактики цих інфекцій. Водночас дослідження застосування добавок вітаміну D у дітей дають суперечливі результати, оскільки немає одностайної думки щодо дозування й частоти застосування вітаміну D.

Отже, вітамін D залишається невід'ємною ланкою процесів, що впливають на імунну відповідь, тому підтримання його оптимального рівня в сироватці крові слід розглядати одним із пріоритетів поліпшення стану здоров'я населення, у тому числі в аспекті профілактики ГРІ в дітей.

Автори заявляють про відсутність конфлікту інтересів. 


\section{REFERENCES/JITEPATУPA}

1. Aglipay M, Birken CS, Parkin PC et al. (2017). Effect of High-Dose vs Standard-Dose Wintertime Vitamin D Supplementation on Viral Upper Respiratory Tract Infections in Young Healthy Children. JAMA. 318: 245.

2. Ali N. (2020). Role of vitamin D in preventing of COVID-19 infection, progression and severity. J Infect Public Health. 13 (10): 1373-1380.

3. Alipio M. (2020). Vitamin D Supplementation Could Possibly Improve Clinical Outcomes of Patients Infected with Coronavirus-2019 (COVID19). SSRN 3571484. URL: https://doi.org/10.2139/ssrn.3571484.

4. Antypkin YH, Kvashnina LV, Omelchenko LI. (2017). Obgruntuvannia doz vitaminu D3 dlia profilaktyky D-vitaminnoi nedostatnosti ta vitamin D-defitsytnykh staniv u zdorovykh ditei riznoho viku. Informatsiinyi lyst. Kyiv: 63. [Антипкін ЮГ, Квашніна ЛВ, Омельченко ЛІ. (2017). Обґрунтування доз вітаміну D3 для профілактики D-вітамінної недостатності та вітамін D-дефіцитних станів у здорових дітей різного віку. Інформаційний лист. Київ: 63].

5. Asghari A, Bagheri Z, Jalessi M, Salem MM, Amini E, GhalehBaghi S, Bakhti S. (2017). Vitamin D Levels in Children with Adenotonsillar Hypertrophy and Otitis Media with Effusion. Iran J Otorhinolaryngol. 29 (90): 29-33.

6. Bikle D, Christakos S. (2020). New aspects of vitamin D metabolism and action - addressing the skin as source and target. Nat Rev Endocrinol. 16 (4): 234-252.

7. Buonsenso DE, Masiello RC, Valentini P. (2017). Vitamin D and Tuberculosis in Children: A Review Vitamin D and Tuberculosis. J Vaccines Immunol: 108

8. Caprio M, Infante M, Calanchini M, Mammi C, Fabbri A. (2017). Vitamin D: not just the bone. Evidence for beneficial pleiotropic extraskeletal effects. Eat Weight Disord. 22 (1): 27-41.

9. Cariolou M, Cupp MA, Evangelou E, Tzoulaki I, Berlanga-Taylor AJ. (2019). Importance of vitamin $D$ in acute and critically ill children with subgroup analyses of sepsis and respiratory tract infections: A systematic review and meta-analysis. BMJ Open. 22; 9 (5): e027666.

10. Cayir A, Turan Ml, Ozkan O, Cayir Y. (2014). Vitamin D levels in children diagnosed with acute otitis media. J Pak Med Assoc. 64 (11): 1274-1277.

11. Chowdhury R, Taneja S, Bhandari N, Sinha B, Upadhyay RP, Bhan MK, Strand TA. (2017). Vitamin-D deficiency predicts infections in young north Indian children: A secondary data analysis. PLoS One. 12 (3): e0170509.

12. Christakos S, Dhawan P, Verstuyf A, Verlinden L, Carmeliet G. (2016). Vitamin D: Metabolism, Molecular Mechanism of Action, and Pleiotropic Effects. PhysiolRev. 96 (1): 365-408.

13. Collak A, Bozaykut A, Demirel B, Sezer RG, Seren LP, Dogru M. (2014). Serum vitamin $D$ levels in children with recurrent tonsillopharyngitis. North Clin Istanb. 1 (1): 13-18.

14. Dankers W, Colin EM, van Hamburg JP, Lubberts E. (2017). Vitamin D in autoimmunity: molecular mechanisms and therapeutic potential. Front Immunol. 7: 697.

15. Demer LL, Hsu JJ, Tintut Y. (2018). Steroid Hormone Vitamin D: Implications for Cardiovascular Disease. Circ Res. 122 (11): 1576-1585

16. Eroglu C, Demir F, Erge D, Uysal P, Kirdar S, Yilmaz M et al. (2019). The relation between serum vitamin $D$ levels, viral infections and severity of attacks in children with recurrent wheezing. Allergol Immunopathol. 47: 591-597.

17. Glicio EJ. (2020). Vitamin D Level of Mild and Severe Elderly Cases of COVID-19: A Preliminary Report. Rochester, NY: Social Science Research Network. URL: https:// papers.ssrn.com/abstract $=3593258$.
18. Golan-Tripto I, Loewenthal N, Tal A, Dizitzer Y, Baumfeld Y, Goldbart A. (2021). Vitamin D deficiency in children with acute bronchiolitis: a prospective cross-sectional case- control study. BMC Pediatr. 21 (1): 211

19. Gou X, Pan L, Tang F, Gao H, Xiao D. (2018). The association between vitamin $\mathrm{D}$ status and tuberculosis in children: A meta-analysis. Medicine (Baltimore). 97 (35): e12179.

20. GrantWB, Lahore H, McDonnell SL, Baggerly CA, French CB, Aliano JL, Bhattoa HP. (2020, Apr 2). Evidence that Vitamin D Supplementation Could Reduce Risk of Influenza and COVID-19 Infections and Deaths. Nutrients. 12 (4): 988.

21. Haugen J, Basnet S, Hardang IM, Sharma A, Mathisen M, Shrestha $P$ et al. (2017). Vitamin D status is associated with treatment failure and duration of illness in Nepalese children with severe pneumonia. Pediatr Res. 82 (6): 986-993.

22. Holick MF. (2007). Vitamin D deficiency. N Engl J Med. 357: 266-281.

23. Holick MF. (2017). The vitamin D deficiency pandemic: approaches for diagnosis, treatment and prevention. Rev Endocr Metab Disord. 18: 153-165.

24. Hollams EM, Teo SM, Kusel M, Holt BJ, Holt KE, Inouye M, De Klerk NH, Zhang G, Sly PD, Hart PH, Holt PG. (2017). Vitamin D over the first decade and susceptibility to childhood allergy and asthma. J Allergy Clin Immunol. 139 (2): 472-481.

25. Hurwitz JL, Jones BG, Penkert RR, Gansebom S, Sun Y, Tang L et al. (2017). Low Retinol Binding Protein and Vitamin D Levels Are Associated with Severe Outcomes in Children Hospitalized with Lower Respiratory Tract Infection and Respiratory Syncytial Virus or Human Metapneumovirus Detection. J Pediatr. 187: 323-327.

26. Inamo $\mathrm{Y}$, Hasegawa M, Saito K, Hayashi R, Ishikawa T, Yoshino $Y$ et al. (2011). Serum vitamin D concentrations and associated severity of acute lower respiratory tract infections in Japanese hospitalized children. Pediatr Int. 53 (2): 199-201.

27. Jadhav S, Khanwelkar C, Jadhav A, Seshla S. (2021). Vitamin D supplementation in the prevention of recurrent acute respiratory tract infections in children aged $<5$ years. J Med Sci. 41: 129-133.

28. Jat KR. (2017). Vitamin D deficiency and lower respiratory tract infections in children: a systematic review and meta-analysis of observational studies. Trop Doct. 47 (1): 77-84

29. Jolliffe DA, Camargo CA Jr, Sluyter JD, Aglipay M et al. (2020). Vitamin D supplementation to prevent acute respiratory infections: systematic review and meta-analysis of aggregate data from randomised controlled trials. medRxiv. doi: 10.1101/2020.07.14.20152728.

30. Jolliffe DA, Griffiths CJ, Martineau AR. (2013). Vitamin D in the prevention of acute respiratory infection: systematic review of clinical studies. J Steroid Biochem Mol Biol. 136: 321-329.

31. Kvashnina LV, Majdan IS. (2020). Vpliv vitaminu D na stan imunnoyi sistemi $\mathrm{v}$ period pandemiyi COVID 19 (novitni dani). Klinichna imunologiya. Alergologiya. Infektologiya. 7 (128): 22-30. [Квашніна ЛВ, Майдан IC. (2020). Вплив вітаміну D на стан імунної системи в період пандемії COVID 19 (новітні дані). Клінічна імунологія. Алергологія. Інфектологія. 7 (128): 22-30].

32. Lau FH, Torabi MR, Saeg F, Hoffman R, Cirillo JD, Greiffenstein P. (2020). Vitamin D insufficiency is prevalent in severe COVID-19. medRxiv. URL: https://doi.org/10.1101/2020.04.24.20075838.

33. Mandal A, Sahi PK. (2017). Serum Vitamin D Levels in Children with Recurrent Respiratory Infections and Chronic Cough: Correspondence. Indian J Pediatr. 84 (2): 172-173. 
34. Marik PE, Kory P, Varon J. (2020). Does vitamin D status impact mortality fromSARS-CoV-2 infection? Med Drug Discov: 100041.

35. Martineau AR, Jolliffe DA, Hooper RL, Greenberg L, Aloia JF, Bergman $P$ et al. (2017). Vitamin D supplementation to prevent acute respiratory tract infections: systematic review and meta-analysis of individual participant data. BMJ. 356: 16583.

36. Marushko YuV, Hyshchak TV. (2021). Prevention of vitamin D deficiency in children. The state of the problem in the world and in Ukraine. Modern Pediatrics. Ukraine. 4 (116): 36-45. doi 10.15574/SP.2021.116.36. [Марушко ЮВ, Гищак ТВ. (2021). Профілактикадефіциту вітаміну D в дітей. Станпроблеми усвіті та Україні. Сучасна педіатрія. Україна. 4 (116): 36-45].

37. McArdle AJ et al. (2020). Vitamin D deficiency is associated with tuberculosis disease in British children. Int J Tuberc Lung Dis. 24: 782-788.

38. McNally JD, Leis K, Matheson LA, Karuananyake C, Sankaran K, Rosenberg AM. (2009). Vitamin D deficiency in young children with severe acute lower respiratory infection. Pediatr Pulmonol. 44 (10): 981-988.

39. McNally JD, Nama N, O'Hearn K, Sampson M, Amrein K, lliriani K et al. (2017). Vitamin D deficiency in critically ill children: a systematic review and meta-analysis. Crit Care. 23; 21 (1): 287.

40. NICE. (2021). National policy and strategy for preventing National policy and strategy for preventing vitamin D deficiency. URL: https:// pathways.nice.org.uk/pathways/vitamin-d-supplement-use-in-specific-population-groups/national-policy-and-strategy-for-preventingvitamin-d-deficiency.

41. Oktaria V, Danchin M, Triasih R, Soenarto Y, Bines JE, Ponsonby AL et al. (2021). The incidence of acute respiratory infection in Indonesian infants and association with vitamin D deficiency. PLoS One. 16 (3): e0248722.

42. Pereira M, Dantas Damascena A, Galvao Azevedo LM, de Almeida Oliveira T, da Mota Santana J. (2020). Vitamin D deficiency aggravates COVID-19: systematic review and meta-analysis. Crit Rev Food Sci Nutr. 4: 1-9.

43. Pham H, Rahman A, Majidi A, Waterhouse M, Neale RE. (2019). Acute Respiratory Tract Infection and 25-Hydroxyvitamin D Concentration: A Systematic Review and Meta-Analysis. Int J Environ Res Public Health. 16 (17): 3020. Published 2019 Aug 21.

44. Ponnarmeni S, Kumar Angurana S, Singhi S, Bansal A, Dayal D, Kaur R, Patial A, Verma Attri S. (2016). Vitamin D deficiency in critically ill children with sepsis. Paediatr Int Child Health. 36 (1): $15-21$
45. Povoroznyuk VV, Balacka NI. (2013). Deficit vitaminu D u naselennya Ukrayini ta chinniki riziku jogo rozvitku. Reprodukt endokrinol. 5 (13): 7-13. [Поворознюк BB, Балацька HI. (2013). Дефіцит вітаміну D у населення України та чинники ризику його розвитку. Репродукт. эндокринол. 5 (13): 7-13].

46. Rhodes JM, Subramanian S, Laird E, Griffin G, Kenny RA. (2021). Perspective: Vitamin D deficiency and COVID-19 severity - plausibly linked by latitude, ethnicity, impacts on cytokines, ACE2 and thrombosis. J Intern Med. 289 (1): 97-115.

47. Sengupta T, Majumder R, Majumder S. (2021). Role of vitamin D in treating COVID-19-associated coagulopathy: problems and perspectives. Mol Cell Biochem. 476 (6): 2421-2427.

48. Shin YH, Yu J, Kim KW, Ahn K, Hong SA. (2013). Association between cord blood 25-hydroxyvitamin $\mathrm{D}$ concentrations and respiratory tract infections in the first 6 months of age in a Korean population: a birth cohort study (COCOA). Korean J Pediatr. 56 (10): 439-445.

49. Song L, Papaioannou G, Zhao H, Luderer HF, Miller C, Dall'Osso C, Nazarian RM, Wagers AJ, Demay MB. (2016). The vitamin D receptor regulates tissue resident macrophage response to injury. Endocrinology. 157: 4066-4075.

50. Taylor SN. (2020). Vitamin D in Toddlers, Preschool Children, and Adolescents. AnnNutrMetab. 76 (2): 30-40.

51. Vertegel AA, Ovcharenko LS. (2014). The vitamin D sufficiency in children with recurrent bronchitis. GeorgianMedNews. 231: 55-59.

52. Vo P, Koppel C, Espinola JA, Mansbach JM, Celed?n JC, Hasegawa K, Bair-Merritt M, Camargo CA Jr. (2018). Vitamin D Status at the Time of Hospitalization for Bronchiolitis and Its Association with Disease Severity. J Pediatr. 203: 416-422.e1.

53. Wang JW, Hogan PG, Hunstad DA, Fritz SA. (2015). Vitamin D sufficiency and Staphylococcus aureus infection in children. Pediatr Infect Dis J. 34 (5): 544-545.

54. Yakoob MY, Salam RA, Khan FR, Bhutta ZA. (2016). Vitamin D supplementation for preventing infections in children under five years of age. Cochrane Database Syst Rev. 11 (11): CD008824.

55. Zhang QY, Yan ZB, Meng YM et al. (2021). Antimicrobial peptides: mechanism of action, activity and clinical potential. Military Med Res. 8: 48. URL: https://doi.org/10.1186/s40779-021-00343-2.

\section{Відомості про авторів:}

Марушко Юрій Володимирович - д.мед.н, проф., зав. каф. педіатрії післядипломної освіти НМУ імені О.О. Богомольця. Адреса: м. Київ, бул. Шевченка, 13.

http://orcid.org/0000000180669369

Єсипова Світлана Іванівна - к.мед.н, доц. каф. педіатрії післядипломної освіти НМУ імені О.О. Богомольця. Адреса: м. Київ, бул. Шевченка, 13. https://orcid.org/0000-0002-8872-936X. Гищак Тетяна Віталіївна - д.мед.н, проф. каф. педіатрії післядипломної освіти НМУ імені О.О. Богомольця. Адреса: м. Київ, бул. Шевченка, 13. http://orcid.org/0000000279207914.

Стаття надійшла до редакції 20.09.2021 р., прийнята до друку 08.12.2021 p. 


\section{CDC \\ Centers for Disease Control and Prevention \\ COVID-19 Vaccines for Children and Teens}

Most Children and All Teens Can Get COVID-19 Vaccines

CDC recommends everyone ages 5 and older get a COVID-19 vaccine to help protect against COVID-19.

\begin{tabular}{|l|c|c|c|}
\hline \multicolumn{1}{|c|}{ Authorized For } & Pfizer-BioNTech & Moderna & J\&J / Janssen \\
\hline 4 years and under & No & No & No \\
\hline 5-11 years old & Yes & No & No \\
\hline $12-17$ years old & Yes & No & Yes \\
\hline 18 years and older & Yes & Yes & \\
\hline
\end{tabular}

Widespread vaccination for COVID-19 is a critical tool to best protect everyone, especially those at highest risk, from severe illness and death. People who are fully vaccinated can safely resume many activities that they did prior to the pandemic. Children ages 5 years and older are able to get an ageappropriate dose of Pfizer-BioNTech COVID-19 vaccine. Learn more about what you and your child or teen can do when fully vaccinated.

Find a COVID-19 Vaccine for Children 5 Years and Older

- The federal government is providing the COVID-19 vaccine free of charge to all people living in the United States, regardless of their immigration or health insurance status.

- Check with your child's healthcare provider about whether they offer COVID-19 vaccination.

- Check your local pharmacy's website to see if vaccination walk-ins or appointments are available for children.

- Contact your state, territorial, local, or tribal health department for more information.

\section{Why Children and Teens Should Get Vaccinated for COVID-19}

While COVID-19 tends to be milder in children compared with adults, it can make children very sick and cause children to be hospitalized. In some situations, the complications from infection can lead to death.

Although children are at a lower risk of becoming severely ill with COVID-19 compared with adults, children can:

- be infected with the virus that causes COVID-19;

- get very sick from COVID-19;

- have both short and long-term health complications from COVID-19;

- spread COVID-19 to others.

Children with underlying medical conditions are more at risk for severe illness from COVID-19 compared with children without underlying medical conditions. Children who get infected with the virus that causes COVID-19 can also develop serious complications like multisystem inflammatory syndrome (MIS-C) - a condition where different body parts become inflamed, including the heart, lungs, kidneys, brain, skin, eyes, or gastrointestinal organs.

Help Protect Your Child, Your Family, and Others

Getting a COVID-19 vaccine can help protect children ages 5 years and older from getting COVID-19.

- Vaccinating children can help protect family members, including siblings who are not eligible for vaccination and family members who may be at increased risk of getting very sick if they are infected.

- Vaccination can also help keep children from getting seriously sick even if they do get COVID-19. 
- Vaccinating children ages 5 years and older can help keep them in school and help them safely participate in sports, playdates, and other group activities.

Help protect your whole family and slow the spread of COVID-19 in your community by getting yourself and your children ages 5 years and older vaccinated against COVID-19.

\section{Protect Unvaccinated Children}

Unvaccinated children ages 2 years and older should wear a mask in public spaces and around people they don't live with.

\section{COVID-19 Vaccines Are Safe for Children and Teens}

Before recommending COVID-19 vaccination for children, scientists conducted clinical trials. The FDA gave the Pfizer-BioNTech COVID-19 vaccine emergency authorization to use in children ages 5-15 years old and full approval to use in people ages 16 years and older.

The benefits of COVID-19 vaccination outweigh the known and potential risks. Get a COVID-19 vaccine for children ages 5 years and older as soon as you can.

COVID-19 vaccines are being monitored for safety with the most comprehensive and intense safety monitoring program in U.S. history. CDC monitors the safety of all COVID-19 vaccines after the vaccines are authorized or approved for use, including the risk of myocarditis in children ages 5 through 11 years.

- Your child may get a COVID-19 vaccine and other vaccines, including flu vaccine, at the same time.

- Serious health events after COVID-19 vaccination are rare.

- Cases of myocarditis (inflammation of the heart muscle) and pericarditis (inflammation of the outer lining of the heart) have been reported after Pfizer-BioNTech COVID-19 vaccination of children ages 12-17 years. These reactions are rare; in one study, the risk of myocarditis after the second dose of Pfizer-BioNTech in the week following vaccination was around 54 cases per million doses administered to males ages $12-17$ years.

- A severe allergic reaction, like anaphylaxis, may happen after any vaccine, including COVID-19 vaccines, but this is rare.

- Your child cannot get COVID-19 from any COVID-19 vaccine, including the Pfizer-BioNTech vaccine.

- There is no evidence that COVID-19 vaccines cause fertility problems.

\section{COVID-19 Vaccine Dosage and Administration for Children and Teens}

- Adolescents ages 12 years and older receive the same dosage of Pfizer-BioNTech COVID-19 vaccine as adults.

- The Pfizer-BioNTech vaccine for children ages 5 through 11 years has the same active ingredients as the vaccine given to adults and adolescents. However, children ages 5 through 11 years cannot get the Pfizer-BioNTech COVID-19 Vaccine given to adults and adolescents. In addition, children ages 5 through 11 years receive an age-appropriate dose that is one-third of the adult dose of PfizerBioNTech COVID-19 vaccine. Smaller needles, designed specifically for children, are also used for children ages 5 through 11 years.

- Unlike many medications, COVID-19 vaccine dosage does not vary by patient weight but by age on the day of vaccination.

- Your child will need a second shot of the Pfizer-BioNTech vaccine three weeks after their first shot.

\section{Preparing Children and Teens for Vaccination}

The experience of getting a COVID-19 vaccine will be very similar to the experience of getting routine vaccines. Use our tips to support your child before, during, and after routine vaccinations when they get a COVID-19 vaccine. 
- Talk to your child before vaccination about what to expect.

- It is not recommended you give pain relievers before vaccination to try to prevent side effects.

- Tell the doctor or nurse about any allergies your child may have.

- To prevent fainting and injuries related to fainting, your child should be seated or lying down during vaccination and for 15 minutes after the vaccine is given.

- After your child's COVID-19 vaccination, you will be asked to stay for 15-30 minutes so your child can be observed in case they have a severe allergic reaction and need immediate treatment.

\section{After Your Child's COVID-19 Vaccination}

\section{Possible side effects}

Your child may have some side effects, which are normal signs that their body is building protection.

\begin{tabular}{|l|l|}
\hline \multicolumn{1}{|c|}{ On the arm where your child got the shot: } & \multicolumn{1}{c|}{ Throughout the rest of their body: } \\
\hline$\bullet$ Pain & $\bullet$ Tiredness \\
$\bullet$ Redness & $\begin{array}{l}\bullet \text { Headache } \\
\bullet \text { Muscle pain } \\
\bullet \text { Swelling }\end{array}$ \\
& $\begin{array}{l}\text { Chills } \\
\bullet \text { Fever } \\
\bullet \text { Nausea }\end{array}$ \\
\hline
\end{tabular}

These side effects may affect your child's ability to do daily activities, but they should go away in a few days. Some people have no side effects and severe allergic reactions are rare. If your child experiences a severe allergic reaction after getting a COVID-19 vaccine, vaccine providers can rapidly provide care and call for emergency medical services, if needed.

Ask your child's healthcare provider for advice on using a non-aspirin pain reliever and other steps you can take at home after your child gets vaccinated. In general, aspirin is not recommended for use in children and adolescents less than 18 years of age. Placing a cool, damp cloth on the injection site can help with discomfort.

\section{Get Started with v-safe}

Get started with v-safe, a free, easy-to-use, and confidential smartphone-based tool that uses text messaging and web surveys to provide personalized health check-ins after your child receives a COVID-19 vaccination. Through v-safe, you can report how your child is feeling after getting vaccinated. V-safe also reminds you when to get your child's second dose. Learn more about v-safe and share this tool with other parents and caregivers to use after vaccination.

More information: https://www.cdc.gov/coronavirus/2019-ncov/vaccines/recommendations/ children-teens.html 


\section{NIH \\ National Institutes of Health \\ COVID-19 Treatment Guidelines*}

The Coronavirus Disease 2019 (COVID-19) Treatment Guidelines is published in an electronic format that can be updated in step with the rapid pace and growing volume of information regarding the treatment of COVID-19.

The COVID-19 Treatment Guidelines Panel (the Panel) is committed to updating this document to ensure that health care providers, patients, and policy experts have the most recent information regarding the optimal management of COVID-19 (see the Panel Roster for a list of Panel members).

New Guidelines sections and recommendations and updates to existing Guidelines sections are developed by working groups of Panel members. All recommendations included in the Guidelines are endorsed by a majority of Panel members (see the Introduction for additional details on the Guidelines development process).

\section{Special Considerations in Children \\ Last Updated: April 21, 2021}

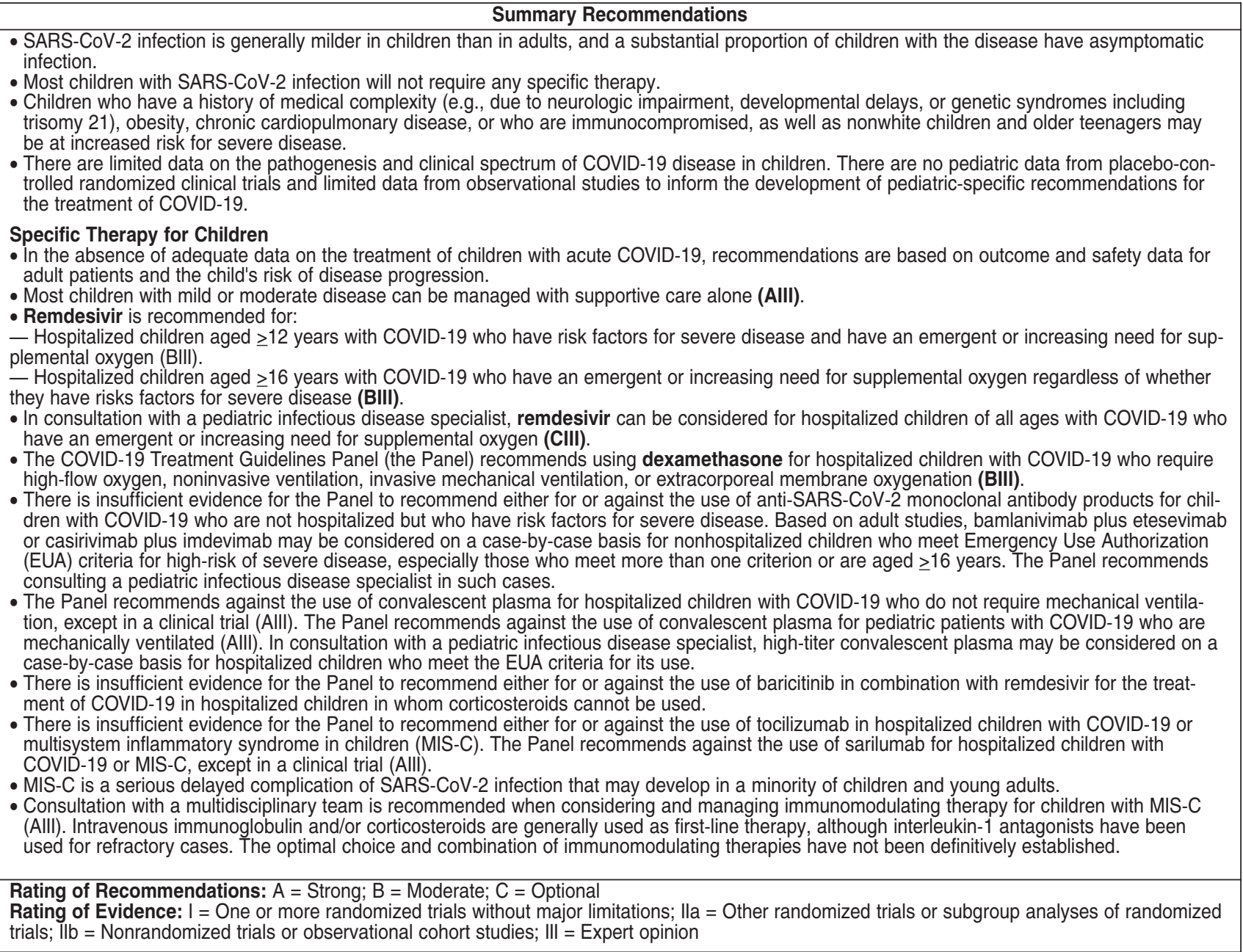

\footnotetext{
*Керівництво наведено зі скороченням. Відібрано розділи для застосування в практичній педіатрії. Закінчення. Повний текст за посиланням: https://files.covid19treatmentguidelines.nih.gov/guidelines/covid19treatmentguidelines.pdf
} 


\section{Epidemiology}

Data from the Centers for Disease Control and Prevention (CDC) demonstrate a lower incidence of SARS-CoV-2 infection and severe disease in children than in adults [1]. However, without more systematic testing for children, including for children with mild symptoms as part of contact tracing, or seroprevalence studies, the true burden of pediatric SARS-CoV-2 infection remains unclear. Data on the pathogenesis and disease severity of SARS-CoV-2 infection in children are increasing but are still limited compared to the data in adults. Several large epidemiologic studies suggest that severe manifestations of acute disease are substantially less common in children than in adults. Although only a small percentage of children with COVID-19 will require medical attention, intensive care unit (ICU)-admission rates for hospitalized children are comparable to those for hospitalized adults with COVID-19 [2-10].

\section{Clinical Manifestations}

The signs and symptoms of SARS-CoV-2 infection in children may be similar to those in adults, but most children may be asymptomatic or only have a few symptoms. The most common signs and symptoms of COVID-19 in hospitalized children are fever, nausea/vomiting, cough, shortness of breath, and upper respiratory symptoms [9,11]. Of note, signs and symptoms of COVID-19 may overlap significantly with those of other viral infections, including influenza and other respiratory and enteric viral infections. Although the true incidence of asymptomatic SARS-CoV-2 infection is unknown, asymptomatic infection was reported in up to $45 \%$ of children who underwent surveillance testing at the time of hospitalization for a non-COVID-19 indication [12].

SARS-CoV-2 has been associated with a potentially severe inflammatory syndrome in children and young adults (multisystem inflammatory syndrome in children [MIS-C]), which is discussed below.

\section{Risk Factors}

Data to clearly establish risk factors for severe COVID-19 in children are limited. Data reported to CDC show lower hospitalization rates and ICU admission rates for children with COVID-19 than for adults with the disease [11,13]. COVID-19-related hospitalization rates for children were highest in children aged $<2$ years and higher in Hispanic and Black children than in White children. The majority of hospitalized children with acute COVID-19 had underlying conditions, with obesity, chronic lung disease, and prematurity (data collected only for children aged $<2$ years) being the most prevalent [14]. Risk factors such as obesity may be more applicable to older teenagers.

In a large study of hospitalized children from the United Kingdom, age $<1$ month, age 10 to 14 years, and Black race were associated with admission to critical care unit on multivariate analysis [9]. Another large multicenter study from Europe identified male sex, pre-existing medical conditions, and the presence of lower respiratory tract disease at presentation as additional risk factors for ICU admission in multivariable models [10].

Deaths associated with COVID-19 among those aged $<21$ years are higher among children aged 10 to 20 years, especially young adults aged 18 to 20 years, as well as among Hispanic, Black, and American Indian/Alaska Native persons.15 A high proportion of the fatal cases of pediatric COVID-19 are in children with underlying medical conditions, most commonly chronic lung disease, obesity, and neurologic and developmental disorders.

Based on data for adults with COVID-19 and extrapolations from data for non-COVID-19 pediatric respiratory viral infections, severely immunocompromised children and those with underlying cardiopulmonary disease may be at higher risk for severe COVID-19. Initial reports of SARS-CoV-2 infection among pediatric patients with cancer and pediatric solid organ transplant recipients have demonstrated a low frequency of infection and associated morbidity [16,20]; however, similar reports for other immunocompromised pediatric populations are limited [21]. A few reports have demonstrated a higher prevalence of asthma in pediatric COVID-19 cases, although the association of asthma with severe disease is not clearly defined $[7,8]$. Congenital heart disease may be associated with increased risk of severe COVID-19, but the condition has not been consistently identified as a risk factor [22,23]. Guidance on the treatment of COVID-19 in children endorsed by the Pediatric Infectious Diseases Society specifies additional risk factors to consider when making decisions about antiviral and monoclonal antibody therapy for pediatric patients [24,25].

Persistent symptoms after acute COVID-19 have been described in adults, although the incidence of this sequelae in children remains unknown and is an active area of research (see Clinical Spectrum of SARS-CoV-2 Infection). Cardiac imaging studies have described myocardial injury in young athletes who had only mild disease [26]; additional studies are needed to determine long-term cardiac sequelae. 
Vertical Transmission and Infants Born to Mothers with SARS-CoV-2 Infection

Vertical transmission of SARS-CoV-2 is thought to be rare, but suspected or probable vertical transmission has been described [27-29]. Initial data on perinatal transmission of SARS-CoV-2 were limited to small case series with conflicting results; some studies demonstrated lack of transmission, whereas others were not able to definitively rule out this possibility [30-33]. Among 100 women with SARS-CoV-2 infection who delivered 101 infants, only two infants had equivocal reverse transcription polymerase chain reaction (RT-PCR) results that may have reflected SARS-CoV-2 infection even though most of the infants remained with their mothers, in rooms with infection prevention measures in place, and were breast fed [34].

Infants born to individuals with SARS-CoV-2 infection may have higher risk of poor clinical outcomes than those born to individuals without SARS-CoV-2 infection, although data are conflicting. In a systematic review of case series in pregnant women with confirmed SARS-CoV-2 infection (predominantly from China), the preterm birth rate was 20.1\% (57 of 284 births were preterm; $95 \%$ CI, 15.8-25.1), the cesarean delivery rate was $84.7 \%$ (33 of 392 births were by cesarean delivery; $95 \%$ CI, 80.8-87.9), there was no vertical transmission, and the neonatal death rate was $0.3 \%$ (1 of 313 neonates died; 95\% CI, 0.1-1.8) [35]. In a prospective cohort study of 263 infants born in the United States, the rates for preterm births, neonatal ICU admissions, and respiratory disease did not differ between infants born to mothers with and without SARS-CoV-2 infection [36]. A cohort study from Sweden demonstrated that 5-minute Apgar scores and birth weight for gestational age did not differ between infants born to mothers with and without SARS-CoV-2 infection [37]. Coronavirus Disease 2019 (COVID-19)Associated Hospitalization Surveillance Network (COVID-NET) data from CDC that captured 598 hospitalized, pregnant women with SARS-CoV-2 infection showed a pregnancy loss rate of $2 \%$ among 458 pregnancies completed during COVID-19-related hospitalizations and a preterm birth rate of $12.9 \%$ compared to $10 \%$ for the general U.S. population [38]. A systematic review and meta-analysis of studies that included 2,567 pregnancies concluded that SARS-CoV-2-positive mothers were at increased risk of iatrogenic preterm birth. This risk was predominantly due to caesarean sections (21.8\% of births) performed due to maternal illness and fear of maternal decompensation. In contrast, there was no increase in the rate of spontaneous preterm birth relative to the expected rate in pregnant individuals without SARS-CoV-2 infection [39,40]. Finally, a prospective cohort study from the United Kingdom of 66 neonates with SARS-CoV-2 infection found that 3\% may have had vertically acquired infection and $12 \%$ had suspected nosocomially acquired infection.29 Specific guidance on the diagnosis and management of COVID-19 in neonates born to mothers with known or suspected SARS-CoV-2 infection is provided by CDC.

\section{Treatment Considerations}

There are no results available from clinical trials evaluating treatment for COVID-19 in children, and observational data on the safety or efficacy of drug therapy in children with COVID-19 are extremely limited. More high-quality studies, including randomized trials, are urgently needed. Guidance for the treatment of COVID-19 in children has been published and is mostly extrapolated from recommendations for adults with COVID-19 [41,42]. The older the child and the more severe the disease, the more reasonable it is to follow recommendations for adult patients with COVID-19 (see Therapeutic Management of Nonhospitalized Adults With COVID-19 and Therapeutic Management of Hospitalized Adults With COVID-19). To address the uncertain safety and efficacy of these treatment options, children should be enrolled in clinical trials and multicenter pragmatic trials whenever possible.

The majority of children with mild or moderate COVID-19 will not progress to more severe illness and thus should be managed with supportive care alone (AIII). The risks and benefits of therapy should be assessed based on illness severity, age, and the presence of risk factors outlined above.

\section{Remdesivir}

Remdesivir is the only drug approved by the Food and Drug Administration (FDA) for the treatment of COVID-19 (see Remdesivir for detailed information). It is approved for the treatment of COVID-19 in hospitalized adult and pediatric patients (aged $\geq 12$ years and weighing $\geq 40 \mathrm{~kg}$ ). It is also available through an FDA Emergency Use Authorization (EUA) for the treatment of COVID-19 in hospitalized pediatric patients weighing $3.5 \mathrm{~kg}$ to $<40 \mathrm{~kg}$ or aged $<12$ years and weighing $\geq 3.5 \mathrm{~kg}$ [43]. Remdesivir has not been evaluated in clinical trials that include children, and there have been no results from systematic evaluations of pharmacokinetics, efficacy, or toxicity in younger children, although studies are ongoing (see ClinicalTrials.gov). However, based on adult data, the potential benefits 
of remdesivir are likely to be greater for hospitalized children with COVID-19 who are at higher risk of progression due to older age (i.e., aged $\geq 16$ years) or medical condition than for those without these risk factors. Remdesivir is recommended for hospitalized children aged $\geq 12$ years with COVID-19 who have risk factors for severe disease and have an emergent or increasing need for supplemental oxygen (BIII). Remdesivir is also recommended for hospitalized children aged $\geq 16$ years with COVID-19 who have an emergent or increasing need for supplemental oxygen even in the absence of risk factors (BIII). Remdesivir can be considered for other hospitalized children of all ages with COVID-19 who have an emergent or increasing need for supplemental oxygen in consultation with a pediatric infectious disease specialist (CIII).

\section{Dexamethasone}

Dexamethasone is recommended for the treatment of hospitalized adults with COVID-19 who require mechanical ventilation or supplemental oxygen through a high-flow device (see Corticosteroids and Therapeutic Management of Hospitalized Adults With COVID-19 for detailed information). The safety and effectiveness of dexamethasone or other corticosteroids for COVID-19 treatment have not been sufficiently evaluated in pediatric patients and thus caution is warranted when extrapolating recommendations for adults to patients aged $<18$ years. The COVID-19 Treatment Guidelines Panel (the Panel) recommends using dexamethasone for children with COVID-19 who require high-flow oxygen, noninvasive ventilation, invasive mechanical ventilation, or extracorporeal membrane oxygenation (ECMO) (BIII). It is not routinely recommended for pediatric patients who require only low levels of oxygen support (i.e., via a nasal cannula only). Use of dexamethasone for the treatment of severe COVID-19 in children who are profoundly immunocompromised has not been evaluated, may be harmful, and therefore should be considered only on a case-by-case basis. If dexamethasone is not available, alternative glucocorticoids such as prednisone, methylprednisolone, or hydrocortisone can be considered. The dexamethasone dosing regimen for pediatric patients is dexamethasone $0.15 \mathrm{mg} / \mathrm{kg} /$ dose (maximum dose $6 \mathrm{mg}$ ) once daily for up to 10 days.

\section{Anti-SARS-CoV-2 Monoclonal Antibodies}

Although EUAs have been issued for bamlanivimab plus etesevimab and casirivimab plus imdevimab for the treatment of nonhospitalized, high-risk patients aged $\geq 12$ years and weighing $\geq 40 \mathrm{~kg}$ with mild to moderate COVID-19, there are currently no data available to determine which high-risk pediatric patients defined in the EUAs will likely benefit from these therapies. Consequently, there is insufficient evidence for the Panel to recommend either for or against the use of these monoclonal antibodies in children with COVID-19 who are not hospitalized but are at high risk of severe disease and/or hospitalization. In consultation with a pediatric infectious disease specialist, bamlanivimab plus etesevimab or casirivimab plus imdevimab can be considered on a case-by-case basis for children who meet the EUA criteria, but should not be considered routine care. This recommendation is primarily based on the absence of data assessing efficacy or safety in children or adolescents, limited data with which to identify children at the highest risk of severe COVID-19, as well as the low overall risk of progression to serious disease in children, and the potential risk associated with infusion reactions.

Additional guidance is provided in a recent publication endorsed by the Pediatric Infectious Diseases Society [25]. There are currently no data to support the use of anti-SARS-CoV-2 monoclonal antibodies in hospitalized children for COVID-19. Emerging data regarding the prevalence and clinical significance of SARS-CoV-2 variants, and the efficacy of monoclonal antibodies against variants, may inform the choice of specific anti-SARS-CoV-2 monoclonal antibody therapy in the future.

\section{Convalescent Plasma}

FDA has also issued an EUA for the use of high-titer convalescent plasma for the treatment of hospitalized patients with COVID-19 (see Convalescent Plasma for detailed information).44 The safety and efficacy of convalescent plasma have not been evaluated in pediatric patients with COVID-19. There is insufficient evidence for the Panel to recommend either for or against the use of convalescent plasma for the treatment of COVID-19 in either pediatric outpatients or in hospitalized children who do not require mechanical ventilation. The Panel recommends against the use of convalescent plasma for pediatric patients with COVID-19 who are mechanically ventilated (AIII). In consultation with a pediatric infectious disease specialist, convalescent plasma may be considered on a case-by-case basis for children who meet the EUA criteria for its use.

\section{Baricitinib}

FDA has also issued an EUA for the use of baricitinib in combination with remdesivir in hospitalized adults and children aged $\geq 2$ years with COVID-19 who require supplemental oxygen, invasive mechanical 
ventilation, or ECMO [45]. The safety and efficacy of baricitinib have not been evaluated in pediatric patients with COVID-19, and pediatric data regarding its use for other conditions are extremely limited. Thus, there is insufficient evidence for the Panel to recommend either for or against the use of baricitinib in combination with remdesivir for the treatment of COVID-19 in hospitalized children in whom corticosteroids cannot be used (see Kinase Inhibitors for detailed information).

\section{Tocilizumab}

Data on tocilizumab use for the treatment of non-COVID-19 conditions in children are limited to very specific clinical scenarios (e.g., chimeric antigen receptor T cell-related cytokine release syndrome) [46].

The use of tocilizumab for severe cases of acute COVID-19 has been described in pediatric case series $[14,47]$. Data on tocilizumab efficacy from trials in adults with COVID-19 are conflicting, and benefit has only been demonstrated in a subset of hospitalized patients (see Interleukin-6 Inhibitors). There is insufficient evidence for the Panel to recommend either for or against the use of tocilizumab for hospitalized children with COVID-19 or MIS-C. If used, tocilizumab should be used in combination with dexamethasone. The Panel recommends against the use of sarilumab for hospitalized children with COVID-19 or MIS-C, except in a clinical trial (AIII).

As for other agents outlined in these Guidelines, there is insufficient evidence for the Panel to recommend either for or against the use of specific antivirals or immunomodulatory agents for the treatment of COVID-19 in pediatric patients. Considerations, such as underlying conditions, disease severity, and potential for drug toxicity or drug interactions, may inform decisions on the use of these agents in pediatric patients with COVID-19 on a case-by-case basis. Children should be enrolled in clinical trials evaluating COVID-19 therapies whenever possible. A number of additional drugs are being investigated for the treatment of COVID-19 in adults; refer to the Antiviral Therapy and Immunomodulators sections to review special considerations for use of these drugs in children and refer to Table 2e and Table 4e for recommendations on pediatric dosing regimens.

\section{Multisystem Inflammatory Syndrome in Children}

A small subset of children and young adults with SARS-CoV-2 infection develop MIS-C. This immune manifestation is also referred to as pediatric multisystem inflammatory syndrome-temporally associated with SARS-CoV-2 (PMIS-TS), although the case definitions for the syndromes differ slightly. This syndrome was first described in Europe, where previously healthy children with severe inflammation and Kawasaki disease-like features were identified to have current or recent infection with SARS-CoV-2. The clinical spectrum of MIS-C has been described in the United States and is similar to that described for PIMS-TS. MIS-C is consistent with a post-infectious inflammatory syndrome related to SARS-CoV-2 [48,49]. Most MIS-C patients have serologic evidence of previous SARS-CoV-2 infection, but only a minority are RT-PCR positive for SARS-CoV-2 at presentation [50,51]. The peak incidence of MIS-C lags about 4 weeks behind the peak of acute pediatric COVID-19 hospitalizations. Emerging data suggests that adults may also develop a similar syndrome, multisystem inflammatory syndrome in adults (MIS-A), although it is not clear if this is a postinfectious complication similar to MIS-C [50-52]. Although risk factors for MIS-C have not been established, in an analysis of MIS-C cases in the United States, most of the children were nonwhite, and obesity was the most common comorbidity [53]. Unlike in children with acute COVID-19, the majority of children who present with MIS-C do not seem to have underlying comorbid conditions other than obesity.

\section{Clinical Manifestations}

The current CDC case definition for MIS-C includes:

- An individual aged $<21$ years presenting with fever (fever $>38.0^{\circ} \mathrm{C}$ for $\geq 24$ hours or report of subjective fever lasting $\geq 24$ hours), laboratory evidence of inflammation (including, but not limited to one or more of the following: an elevated C-reactive protein, erythrocyte sedimentation rate, fibrinogen, procalcitonin, d-dimer, ferritin, lactic acid dehydrogenase, interleukin (IL)-6, or neutrophils, or reduced lymphocytes or albumin levels), and evidence of clinically severe illness requiring hospitalization with multisystem (i.e., more than two) organ involvement (cardiac, renal, respiratory, hematologic, gastrointestinal, dermatologic, or neurological); and

- No alternative plausible diagnoses; and

- Positive for current or recent SARS-CoV-2 infection by RT-PCR, antigen test, or serology; or COVID-19 exposure within the 4 weeks prior to the onset of symptoms [54].

Distinguishing MIS-C from other febrile illnesses in the community setting remains challenging, but 
presence of persistent fever, multisystem manifestations, and laboratory abnormalities could help early recognition [55]. The clinical spectrum of hospitalized cases has included younger children with mucocutaneous manifestations that overlap those with Kawasaki disease, older children with more multiorgan involvement and shock, and patients with respiratory manifestations that overlap with acute COVID-19. Patients with MIS-C are often critically ill and up to $80 \%$ of children require ICU admission [532]. Most patients with MIS-C have markers of cardiac injury or dysfunction, including elevated levels of troponin and brain natriuretic protein [50,51]. Echocardiographic findings in these cases include impaired left ventricular function, as well as coronary artery dilations, and rarely, coronary artery aneurysms. Reported mortality rate in the United States for hospitalized children with MIS-C is $1 \%$ to $2 \%$. Longitudinal studies are currently ongoing to examine the long-term sequelae of MIS-C.

The pathogenesis of MIS-C is still being elucidated. Differences have been demonstrated between MIS-C and typical Kawasaki disease in terms of epidemiology, cytopenias, cytokine expression, and elevation of inflammatory markers. Immunologic profiling has also shown differences in cytokine expression (tumor necrosis factor alpha and IL-10) between MIS-C and acute COVID-19 in children [56-58].

\section{Management}

Currently, there are only observational data available to guide treatment for MIS-C. Supportive care remains the mainstay of therapy. There is currently insufficient evidence for the Panel to recommend either for or against any specific therapeutic strategy for the management of MIS-C. MIS-C management decisions should involve a multidisciplinary team of pediatric specialists including experts in intensive care, infectious diseases, cardiology, hematology, and rheumatology. Although no clinical trial data are available, many centers have described the use of immunomodulatory therapy (e.g., intravenous immune globulin [IVIG], corticosteroids, IL-1 and IL-6 inhibitors). The American College of Rheumatology has outlined initial diagnostic and treatment considerations for MIS-C, recommending IVIG and/or corticosteroids as first-tier therapies and other biologic agents as second-line options $[48,49,59]$. An observational study from Europe used propensity matching to compare short-term outcomes in children with MIS-C who were treated initially with IVIG alone or IVIG and methylprednisolone. They observed a lower risk of treatment failure (defined as persistence of fever), more rapid improvement in hemodynamic support, less severe left ventricular dysfunction, and shorter ICU stays among children initially treated with the combination therapy [60]. These findings must be confirmed with additional prospective studies. The role of antiviral therapy in MIS-C is not clear, therefore the use of remdesivir should be reserved for patients who have features of acute COVID-19.

\section{References}

1. Centers for Disease Control and Prevention. COVID-19: information for pediatric healthcare providers. 2020. Available at: https://www.cdc.gov/coronavirus/2019-ncov/hcp/pediatric-hcp.html. Accessed March 26, 2021.

2. Dong Y, Mo X, Hu Y, et al. Epidemiology of COVID-19 among children in China. Pediatrics. 2020;145(6). Available at: https://www.ncbi.nlm.nih.gov/pubmed/32179660.

3. Centers for Disease Control and Prevention. Coronavirus disease 2019 in children-United States, February 12-April 2, 2020. 2020. Available at: https://www.cdc.gov/mmwr/volumes/69/wr/mm6914e4.htm. Accessed: January 5, 2021.

4. Cui X, Zhang T, Zheng J, et al. Children with coronavirus disease 2019 (COVID-19): a review of demographic, clinical, laboratory and imaging features in 2,597 pediatric patients. J Med Virol. 2020;92(9):1501-1510. Available at: https://www.ncbi.nlm.nih.gov/pubmed/32418216.

5. Livingston E, Bucher K. Coronavirus Disease 2019 (COVID-19) in Italy. JAMA. 2020;323(14):1335. Available at: https://www.ncbi.nlm.nih.gov/pubmed/32181795.

6. Tagarro A, Epalza C, Santos M, et al. Screening and severity of coronavirus disease 2019 (COVID-19) in children in Madrid, Spain. JAMA Pediatr. 2020;Published online ahead of print. Available at: https://www.ncbi.nlm.nih.gov/pubmed/32267485.

7. DeBiasi RL, Song X, Delaney M, et al. Severe COVID-19 in children and young adults in the Washington, DC metropolitan region. J Pediatr. 2020;223:199-203.e1. Available at: https://www.ncbi.nlm.nih.gov/pubmed/32405091.

8. Chao JY, Derespina KR, Herold BC, et al. Clinical characteristics and outcomes of hospitalized and critically ill children and adolescents with coronavirus disease 2019 (COVID-19) at a tertiary care medical center in New York City. J Pediatr. 2020;223:14-19.e2. Available at: https://www.ncbi.nlm.nih.gov/pubmed/32407719.

9. Swann OV, Holden KA, Turtle L, et al. Clinical characteristics of children and young people admitted to hospital with COVID19 in United Kingdom: prospective multicentre observational cohort study. BMJ. 2020;370:m3249. Available at: https://www.ncbi.nlm.nih.gov/pubmed/32960186.

10. Gotzinger F, Santiago-Garcia B, Noguera-Julian A, et al. COVID-19 in children and adolescents in Europe: a multination- 
al, multicentre cohort study. Lancet Child Adolesc Health. 2020;4(9):653-661. Available at: https://www.ncbi.nlm.nih.gov/pubmed/32593339.

11. Kim L, Whitaker M, O'Halloran A, et al. Hospitalization rates and characteristics of children aged $<18$ years hospitalized with laboratory-confirmed COVID-19-COVID-NET, 14 States, March 1-July 25, 2020. MMWR Morb Mortal Wkly Rep. 2020;69(32):1081-1088. Available at: https://www.ncbi.nlm.nih.gov/pubmed/32790664.

12. Poline J, Gaschignard J, Leblanc C, et al. Systematic SARS-CoV-2 screening at hospital admission in children: a French prospective multicenter study. Clin Infect Dis. 2020;Published online ahead of print. Available at: https://www.ncbi.nlm.nih.gov/pubmed/32710743.

13. Leidman E, Duca LM, Omura JD, Proia K, Stephens JW, Sauber-Schatz EK. COVID-19 trends among persons aged 0-24 years-United States, March 1-December 12, 2020. MMWR Morb Mortal Wkly Rep. 2021;70(3):88-94. Available at: https://www.ncbi.nlm.nih.gov/pubmed/33476314.

14. Shekerdemian LS, Mahmood NR, Wolfe KK, et al. Characteristics and outcomes of children with coronavirus disease 2019 (COVID-19) infection admitted to US and Canadian pediatric intensive care units. JAMA Pediatr. 2020;174(9):868-873. Available at: https://www.ncbi.nlm.nih.gov/pubmed/32392288.

15. Bixler D, Miller AD, Mattison CP, et al. SARS-CoV-2-associated deaths among persons aged <21 years-United States, February 12-July 31, 2020. MMWR Morb Mortal Wkly Rep. 2020;69(37):1324-1329. Available at: https://www.ncbi.nlm.nih.gov/pubmed/32941417.

16. Goss MB, Galvan NTN, Ruan W, et al. The pediatric solid organ transplant experience with COVID-19: an initial multi-center, multi-organ case series. Pediatr Transplant. 2020:e13868. Available at: https://www.ncbi.nlm.nih.gov/pubmed/32949098.

17. Bisogno G, Provenzi M, Zama D, et al. Clinical characteristics and outcome of severe acute respiratory syndrome coronavirus 2 infection in Italian pediatric oncology patients: a study from the Infectious Diseases Working Group of the Associazione Italiana di Oncologia e Ematologia Pediatrica. J Pediatric Infect Dis Soc. 2020;9(5):530-534. Available at: https://www.ncbi.nlm.nih.gov/pubmed/32652521.

18. Boulad F, Kamboj M, Bouvier N, Mauguen A, Kung AL. COVID-19 in children with cancer in New York City. JAMA Oncol. 2020;6(9):1459-1460. Available at: https://www.ncbi.nlm.nih.gov/pubmed/32401276.

19. de Rojas T, Perez-Martinez A, Cela E, et al. COVID-19 infection in children and adolescents with cancer in Madrid. Pediatr Blood Cancer. 2020;67(7):e28397. Available at: https://www.ncbi.nlm.nih.gov/pubmed/32383819.

20. Hrusak $\mathrm{O}$, Kalina $\mathrm{T}$, Wolf $\mathrm{J}$, et al. Flash survey on severe acute respiratory syndrome coronavirus-2 infections in paediatric patients on anticancer treatment. Eur $J$ Cancer. 2020;132:11-16. Available at: https://www.ncbi.nlm.nih.gov/pubmed/32305831.

21. Freeman MC, Rapsinski GJ, Zilla ML, Wheeler SE. Immunocompromised seroprevalence and course of illness of SARSCoV-2 in one pediatric quaternary care center. J Pediatric Infect Dis Soc. 2020;Published online ahead of print. Available at: https://www.ncbi.nlm.nih.gov/pubmed/33049042.

22. Madhusoodhan PP, Pierro J, Musante J, et al. Characterization of COVID-19 disease in pediatric oncology patients: the New York-New Jersey regional experience. Pediatr Blood Cancer. 2021;68(3):e28843. Available at: https://www.ncbi.nlm.nih.gov/pubmed/33338306.

23. Lewis MJ, Anderson BR, Fremed M, et al. Impact of coronavirus disease 2019 (COVID-19) on patients with congenital heart disease across the lifespan: the experience of an academic congenital heart disease center in New York City. J Am Heart Assoc. 2020;9(23):e017580. Available at: https://www.ncbi.nlm.nih.gov/pubmed/33196343.

24. Chiotos K, Hayes M, Kimberlin DW, et al. Multicenter interim guidance on use of antivirals for children with coronavirus disease 2019/severe acute respiratory syndrome coronavirus 2. J Pediatric Infect Dis Soc. 2021;10(1):34-48. Available at: https://www.ncbi.nlm.nih.gov/pubmed/32918548.

25. Wolf $\mathrm{J}$, Abzug MJ, Wattier RL, et al. Initial guidance on use of monoclonal antibody therapy for treatment of COVID-19 in children and adolescents. J Pediatric Infect Dis Soc. 2021;Published online ahead of print. Available at: https://www.ncbi.nlm.nih.gov/pubmed/33388760.

26. Rajpal S, Tong MS, Borchers J, et al. Cardiovascular magnetic resonance findings in competitive athletes recovering from COVID-19 infection. JAMA Cardiol. 2021;6(1):116-118. Available at: https://www.ncbi.nlm.nih.gov/pubmed/32915194

27. Demirjian A, Singh C, Tebruegge M, et al. Probable vertical transmission of SARS-CoV-2 infection. Pediatr Infect Dis J. 2020;39(9):e257-e260. Available at: https://www.ncbi.nlm.nih.gov/pubmed/32658096.

28. Dong L, Tian J, He S, et al. Possible vertical transmission of SARS-CoV-2 From an infected mother to her newborn. JAMA. 2020;323(18):1846-1848. Available at: https://www.ncbi.nlm.nih.gov/pubmed/32215581.

29. Gale C, Quigley MA, Placzek A, et al. Characteristics and outcomes of neonatal SARS-CoV-2 infection in the UK: a prospective national cohort study using active surveillance. Lancet Child Adolesc Health. 2021;5(2):113-121. Available at: https://www.ncbi.nlm.nih.gov/pubmed/33181124.

30. Chen H, Guo J, Wang C, et al. Clinical characteristics and intrauterine vertical transmission potential of COVID-19 infection in nine pregnant women: a retrospective review of medical records. Lancet. 2020;395(10226):809-815. Available at: https://www.ncbi.nlm.nih.gov/pubmed/32151335.

31. Fan C, Lei D, Fang C, et al. Perinatal transmission of COVID-19 associated SARS-CoV-2: should we worry? Clin Infect Dis. 2021;72(5):862-864. Available at: https://www.ncbi.nlm.nih.gov/pubmed/32182347.

32. Zeng L, Xia S, Yuan W, et al. Neonatal early-onset infection with SARS-CoV-2 in 33 neonates born to mothers with COVID-19 in Wuhan, China. JAMA Pediatr. 2020;174(7):722-725. Available at: https://www.ncbi.nlm.nih.gov/pubmed/32215598.

33. Von Kohorn I, Stein SR, Shikani BT, et al. In utero severe acute respiratory syndrome voronavirus 2 infection. J Pediatric Infect Dis Soc. 2020;9(6):769-771. Available at: https://www.ncbi.nlm.nih.gov/pubmed/33089311.

34. Dumitriu D, Emeruwa UN, Hanft E, et al. Outcomes of neonates born to mothers with severe acute respiratory syndrome coronavirus 2 infection at a large medical center in New York City. JAMA Pediatr. 2021;175(2):157-167. Available at: https://www.ncbi.nlm.nih.gov/pubmed/33044493. 
35. Huntley BJF, Huntley ES, Di Mascio D, Chen T, Berghella V, Chauhan SP. Rates of maternal and perinatal mortality and vertical transmission in pregnancies complicated by severe acute respiratory syndrome coronavirus 2 (SARS-Co-V-2) infection: a systematic review. Obstet Gynecol. 2020;136(2):303-312. Available at: https://www.ncbi.nlm.nih.gov/pubmed/32516273.

36. Flaherman VJ, AfsharY, Boscardin J, et al. Infant outcomes following maternal infection with SARS-CoV-2: first report from the PRIORITY study. Clin Infect Dis. 2020;Published online ahead of print. Available at: https://www.ncbi.nlm.nih.gov/pubmed/32947612.

37. Ahlberg M, Neovius M, Saltvedt S, et al. Association of SARS-CoV-2 test status and pregnancy outcomes. JAMA. 2020;324(17):1782-1785. Available at: https://www.ncbi.nlm.nih.gov/pubmed/32965467.

38. Delahoy MJ, Whitaker M, O'Halloran A, et al. Characteristics and maternal and birth outcomes of hospitalized pregnant women with laboratory-confirmed COVID-19 - COVID-NET, 13 states, March 1-August 22, 2020. MMWR Morb Mortal Wkly Rep. 2020;69(38):1347-1354. Available at: https://www.ncbi.nlm.nih.gov/pubmed/32970655.

39. Khalil A, Kalafat E, Benlioglu C, et al. SARS-CoV-2 infection in pregnancy: a systematic review and meta-analysis of clinical features and pregnancy outcomes. EClinicalMedicine. 2020;25:100446. Available at: https://www.ncbi.nlm.nih.gov/pubmed/32838230.

40. Khoury R, Bernstein PS, Debolt C, et al. Characteristics and outcomes of 241 births to women with severe acute respiratory syndrome coronavirus 2 (SARS-CoV-2) infection at five New York City medical centers. Obstet Gynecol. 2020;136(2):273-282. Available at: https://www.ncbi.nlm.nih.gov/pubmed/32555034.

41. Chiotos K, Hayes M, Kimberlin DW, et al. Multicenter initial guidance on use of antivirals for children with COVID-19/SARSCoV-2. J Pediatric Infect Dis Soc. 2020;9(6):701-715. Available at: https://www.ncbi.nlm.nih.gov/pubmed/32318706.

42. Dulek DE, Fuhlbrigge RC, Tribble AC, et al. Multidisciplinary guidance regarding the use of immunomodulatory therapies for acute coronavirus disease 2019 in pediatric patients. J Pediatric Infect Dis Soc. 2020;9(6):716-737. Available at: https://www.ncbi.nlm.nih.gov/pubmed/32808988.

43. Food and Drug Administration. Fact sheet for healthcare providers: emergency use authorization (EUA) of veklury (remdesivir) for hospitalized pediatric patients weighing $3.5 \mathrm{~kg}$ to less than $40 \mathrm{~kg}$ or hospitalized pediatric patients less than 12 years of age weighing at least $3.5 \mathrm{~kg}$. 2020. Available at: https://www.fda.gov/media/137566/download.

44. Food and Drug Administration. EUA 26382: Emergency Use Authorization (EUA) Decision Memo. 2020. Available at: https://www.fda.gov/media/141480/download.

45. Food and Drug Administration. Letter of authorization: EUA for baricitinib (Olumiant), in combination with remdesivir (Veklury), for the treatment of suspected or laboratory confirmed coronavirus disease 2019 (COVID-19). 2020. Available at: https://www.fda.gov/media/143822/download.

46. Kotch C, Barrett D, Teachey DT. Tocilizumab for the treatment of chimeric antigen receptor T cell-induced cytokine release syndrome. Expert Rev Clin Immunol. 2019;15(8):813-822. Available at: https://www.ncbi.nlm.nih.gov/pubmed/31219357.

47. Derespina KR, Kaushik S, Plichta A, et al. Clinical manifestations and outcomes of critically ill children and adolescents with coronavirus disease 2019 in New York City. J Pediatr. 2020;Published online ahead of print. Available at: https://www.ncbi.nlm.nih.gov/pubmed/32681989.

48. Riphagen S, Gomez X, Gonzalez-Martinez C, Wilkinson N, Theocharis P. Hyperinflammatory shock in children during COVID19 pandemic. Lancet. 2020;395(10237):1607-1608. Available at: https://www.ncbi.nlm.nih.gov/pubmed/32386565.

49. Whittaker E, Bamford A, Kenny J, et al. Clinical characteristics of 58 children with a pediatric inflammatory multisystem syndrome temporally associated with SARS-CoV-2. JAMA. 2020;324(3):259-269. Available at: https://www.ncbi.nlm.nih.gov/pubmed/32511692.

50. Dufort EM, Koumans EH, Chow EJ, et al. Multisystem inflammatory syndrome in children in New York State. N Engl J Med. 2020;383(4):347-358. Available at: https://www.ncbi.nlm.nih.gov/pubmed/32598830.

51. Feldstein LR, Rose EB, Horwitz SM, et al. Multisystem inflammatory syndrome in U.S. children and adolescents. N Engl J Med. 2020;383(4):334-346. Available at: https://www.ncbi.nlm.nih.gov/pubmed/32598831.

52. Morris SB, Schwartz NG, Patel P, et al. Case series of multisystem inflammatory syndrome in adults associated with SARSCoV-2 infection-United Kingdom and United States, March-August 2020. MMWR Morb Mortal Wkly Rep. 2020;69(40):1450-1456. Available at: https://www.ncbi.nlm.nih.gov/pubmed/33031361.

53. Godfred-Cato S, Bryant B, Leung J, et al. COVID-19-associated multisystem inflammatory syndrome in children-United States, March--July 2020. MMWR Morb Mortal Wkly Rep. 2020;69(32):1074-1080. Available at: https://www.ncbi.nlm.nih.gov/pubmed/32790663.

54. Centers for Disease Control and Prevention. Information for healthcare providers about multisystem inflammatory syndrome in children (MIS-C). 2021. Available at: https://www.cdc.gov/mis-c/hcp/. Accessed March 26, 2021.

55. Carlin RF, Fischer AM, Pitkowsky Z, et al. Discriminating multisystem inflammatory syndrome in children requiring treatment from common febrile conditions in outpatient settings. J Pediatr. 2021;229:26-32 e22. Available at: https://www.ncbi.nlm.nih.gov/pubmed/33065115.

56. Lee PY, Day-Lewis M, Henderson LA, et al. Distinct clinical and immunological features of SARS-CoV-2-induced multisystem inflammatory syndrome in children. J Clin Invest. 2020;130(11):5942-5950. Available at: https://www.ncbi.nlm.nih.gov/pubmed/32701511.

57. Rowley AH, Shulman ST, Arditi M. Immune pathogenesis of COVID-19-related multisystem inflammatory syndrome in children. J Clin Invest. 2020;130(11):5619-5621. Available at: https://www.ncbi.nlm.nih.gov/pubmed/32870815.

58. Diorio C, Henrickson SE, Vella LA, et al. Multisystem inflammatory syndrome in children and COVID-19 are distinct presentations of SARS-CoV-2. J Clin Invest. 2020;130(11):5967-5975. Available at: https://www.ncbi.nlm.nih.gov/pubmed/32730233.

59. Henderson LA, Canna SW, Friedman KG, et al. American College of Rheumatology clinical guidance for multisystem inflammatory syndrome in children associated with SARS-CoV-2 and hyperinflammation in pediatric COVID-19: version 2. Arthritis Rheumatol. 2020;Published online ahead of print. Available at: https://www.ncbi.nlm.nih.gov/pubmed/33277976.

60. Ouldali N, Toubiana J, Antona D, et al. Association of intravenous immunoglobulins plus methylprednisolone vs immunoglobulins alone with course of fever in multisystem inflammatory syndrome in children. JAMA. 2021;325(9):855-864. Available at: https://www.ncbi.nlm.nih.gov/pubmed/33523115. 


\title{
Special Considerations in Adults and Children With Cancer Last Updated: April 21, 2020
}

\begin{abstract}
Summary Recommendations
- Given the effectiveness of the SARS-CoV-2 vaccines in the general population and the increased risk of severe COVID-19 and mortality in patients with cancer, the COVID-19 Treatment Guidelines Panel (the Panel) recommends SARS-CoV-2 vaccination for patients with active cancer or patients who are receiving treatment for cancer (AIII). See the text below for information on the appropriate timing for SARS-CoV-2 vaccination in these patients.

- The Panel recommends performing molecular diagnostic testing for SARS-CoV-2 in patients with cancer who develop signs and symptoms that suggest COVID-19 (AIII) and in asymptomatic patients prior to procedures that require anesthesia and before initiating cytotoxic chemotherapy and long-acting biologic therapy (BIII).

- The recommendations for treating COVID-19 in patients with cancer are the same as those for the general population (AIII). See Antiviral Drugs That Are Approved or Under Evaluation for the Treatment of COVID-19 and Immunomodulators Under Evaluation for the Treatment of COVID-19 for more information.

- Clinicians should pay careful attention to potential drug-drug interactions and overlapping toxicities between drugs that are used to treat COVID-19 and cancer-directed therapies, prophylactic antimicrobials, corticosteroids, and other medications (AlII).

- Clinicians who are treating COVID-19 in patients with cancer should consult a hematologist or oncologist before adjusting cancer-directed medications (AlII).

- Decisions about administering cancer-directed therapy during SARS-CoV-2 infection should be made on a case-by-case basis; clinicians should consider the indication for chemotherapy, the goals of care, and the patient's history of tolerance to the treatment (BIII).

Rating of Recommendations: $\mathrm{A}=$ Strong; $\mathrm{B}=$ Moderate; $\mathrm{C}=$ Optional

Rating of Evidence: I = One or more randomized trials without major limitations; lla = Other randomized trials or subgroup analyses of randomized trials; Ilb = Nonrandomized trials or observational cohort studies; III = Expert opinion
\end{abstract}

People who are being treated for cancer may be at increased risk of severe COVID-19, and clinical outcomes of COVID-19 are generally worse in people with cancer than in people without cancer [1-4]. A meta-analysis of 46,499 patients with COVID-19 showed that all-cause mortality (risk ratio 1.66; $95 \%$ CI, 1.33-2.07) was higher in patients with cancer, and that patients with cancer were more likely to be admitted to intensive care units (risk ratio 1.56; 95\% CI, 1.31-1.87) [5]. The risk for immunosuppression and susceptibility to SARS-CoV-2 infection varies between cancer types, treatments administered, and stages of therapy (e.g., patients who are actively being treated compared to those in remission). In a study that used data from the COVID-19 and Cancer Consortium Registry, cancer patients who were in remission or who had no evidence of disease were at a lower risk of death from COVID-19 than those who were receiving active treatment [6]. It is unclear whether cancer survivors are at increased risk for severe COVID-19 and its complications compared to people without a history of cancer.

Many organizations have outlined recommendations for treating patients with cancer during the COVID-19 pandemic, such as:

- National Comprehensive Cancer Network (NCCN)

- American Society of Hematology

- American Society of Clinical Oncology

- Society of Surgical Oncology

- American Society for Radiation Oncology

- International Lymphoma Radiation Oncology Group

This section of the COVID-19 Treatment Guidelines complements these sources and focuses on considerations regarding testing for SARS-CoV-2, managing COVID-19 in patients with cancer, and managing cancer-directed therapies during the COVID-19 pandemic. The optimal management and therapeutic approach to COVID-19 in this population has not yet been defined.

\section{Vaccination for SARS-CoV-2 in Patients With Cancer}

The clinical trials that evaluated the SARS-CoV-2 vaccines that have received Emergency Use Authorizations from the Food and Drug Administration excluded severely immunocompromised patients. The Advisory Committee on Immunization Practices notes that the authorized SARS-CoV-2 vaccines are not live vaccines; therefore, they can be safely administered to immunocompromised people [7]. Given the effectiveness of the SARS-CoV-2 vaccines in the general population and the increased risk of severe COVID-19 and mortality in patients with cancer, the COVID-19 Treatment Guidelines Panel (the Panel) recommends SARS-CoV-2 vaccination for patients with active cancer or patients who are receiving treatment for cancer (AIII).

The mRNA vaccines contain polyethylene glycol (PEG), and the Johnson \& Johnson (J\&J)/Janssen vaccine contains polysorbate. In patients who experience a severe anaphylactic reaction to PEGasparaginase, consider performing allergy testing for PEG prior to vaccination with either of the mRNA vaccines or consider using the $\mathrm{J} \& \mathrm{~J} / \mathrm{J}$ anssen vaccine with precautions [8-10]. 
When determining the timing of SARS-CoV-2 vaccination in patients with cancer, clinicians should consider the following factors:

- If possible, patients who are planning to receive chemotherapy should complete vaccination for SARS-CoV-2 at least 2 weeks before starting chemotherapy [11,12].

- In patients with hematologic malignancy who are undergoing intensive chemotherapy (e.g., induction chemotherapy for acute myelogenous leukemia), vaccination should be delayed until neutrophil recovery [13].

- Hematopoietic stem cell and chimeric antigen receptor T cell recipients can be offered SARS-CoV2 vaccination starting at least 3 months after therapy [12].

It is unknown whether the immune response to SARS-CoV-2 vaccination can increase the risk of graft-versus-host disease or other immune-related complications. Studies of responses to influenza vaccination have shown that the immune response in cancer patients varies based on the type of cancer, whether the patient has received chemotherapy recently, and the type of chemotherapy [14,15]. Additional research is needed to understand the vaccine response in patients with cancer. Outside of a clinical study, antibody testing is not recommended to assess immunity to SARS-CoV-2 following vaccination in patients with cancer. For people who received COVID-19 vaccines during chemotherapy or treatment with other immunosuppressive drugs, revaccination after they regain immune competence is currently not recommended [7].

Vaccination of household members, close contacts, and health care providers who provide care for immunocompromised patients is imperative to protect immunocompromised patients from infection. All close contacts are strongly encouraged to get vaccinated as soon as possible.

\section{Testing for COVID-19 in Patients With Cancer}

The Panel recommends molecular diagnostic testing for SARS-CoV-2 in patients with cancer who develop signs and symptoms of COVID-19 (AIII).

Patients with cancer who are receiving chemotherapy are at risk of developing neutropenia. The NCCN Guidelines for Hematopoietic Growth Factors categorizes cancer treatment regimens based on the risk of developing neutropenia. A retrospective study suggests that cancer patients with neutropenia have a higher mortality rate if they develop COVID-19 [16]. Due to the potential risk of poor clinical outcomes in the setting of neutropenia and/or during the perioperative period, the Panel recommends performing molecular diagnostic testing for SARS-CoV-2 prior to procedures that require anesthesia and before initiating cytotoxic chemotherapy and long-acting biologic therapy (BIII) [17,18].

General Guidance on Medical Care for Patients With Cancer During the COVID-19 Pandemic

Patients with cancer frequently engage with the health care system to receive treatment and supportive care for cancer and/or treatment-related complications. Telemedicine can minimize the need for inperson services and reduce the risk of SARS-CoV-2 exposure. The Centers for Disease Control and Prevention published a framework to help clinicians decide whether a patient should receive in-person or virtual care during the COVID-19 pandemic; this framework accounts for factors such as the potential harm of delayed care and the degree of SARS-CoV-2 transmission in a patient's community [19]. Telemedicine may improve access to providers for medically or socially vulnerable populations but could worsen disparities if these populations have limited access to technology. Nosocomial transmission of SARS-CoV-2 to patients and health care workers has been reported [20-22]. Principles of physical distancing and prevention strategies, including masking patients and health care workers and practicing hand hygiene, apply to all in-person interactions [23].

Decisions about treatment regimens, surgery, and radiation therapy for the underlying malignancy should be made on an individual basis depending on the biology of the cancer, the need for hospitalization, the number of clinic visits required, and the anticipated degree of immunosuppression. Several key points should be considered:

- If possible, treatment delays should be avoided for curable cancers that have been shown to have worse outcomes when treatment is delayed (e.g., pediatric acute lymphoblastic leukemia).

- When deciding between equally effective treatment regimens, regimens that can be administered orally or those that require fewer infusions are preferred [24,25].

- The potential risks of drug-related lung toxicity (e.g., from using bleomycin or PD-1 inhibitors) must be balanced with the clinical efficacy of alternative regimens or the risk of delaying care [26].

- Preventing neutropenia can decrease the risk of neutropenic fever and the need for emergency department evaluation and hospitalization during the COVID-19 pandemic. Granulocyte colony- 
stimulating factor (G-CSF) should be given with chemotherapy regimens that have intermediate (10\% to $20 \%$ ) or high $(>20 \%)$ risk of febrile neutropenia [27].

- Cancer treatment regimens that do not affect outcomes of COVID-19 in cancer patients may not need to be altered. In a prospective observational study, receipt of immunotherapy, hormonal therapy, or radiotherapy in the month prior to SARS-CoV-2 infection was not associated with an increased risk of mortality among cancer patients with COVID-19 [28]. A retrospective study from Italy evaluated the incidence of SARS-CoV-2 infection in patients with prostate cancer and found that 114 of 37,161 patients $(0.3 \%)$ who were treated with therapies other than androgen deprivation therapy became infected, compared to 4 of 5,273 patients $(0.08 \%)$ who were treated with androgen deprivation therapy (OR 4.05; 95\% CI, 1.55-10.59) [29]. A small cohort study of patients with prostate cancer from Finland did not find an association between androgen deprivation and incidence of SARS-CoV-2 infection [30]. The viral spike proteins that SARS-CoV-2 uses to enter cells are primed by TMPRSS2, an androgenregulated gene. Whether androgen deprivation therapy protects against SARS-CoV-2 infection requires further investigation in larger cohorts or clinical trials [29].

- Radiation therapy guidelines suggest increasing the dose per fraction and reducing the number of daily treatments in order to minimize the number of hospital visits during the COVID-19 pandemic [24,25].

Blood supply shortages will likely continue during the COVID-19 pandemic due to social distancing, cancellation of blood drives, and infection among donors. Revised donor criteria have been proposed by the Food and Drug Administration to increase the number of eligible donors [31]. In patients with cancer, lowering the transfusion thresholds for blood products (e.g., red blood cells, platelets) in asymptomatic patients should be considered [32,33]. At this time, there is no evidence that COVID-19 can be transmitted through blood products [34,35].

\section{Febrile Neutropenia}

Cancer patients with febrile neutropenia should undergo molecular diagnostic testing for SARS$\mathrm{CoV}-2$ and evaluation for other infectious agents; they should also be given empiric antibiotics, as outlined in the NCCN Guidelines [36]. Low-risk febrile neutropenia patients should be treated at home with oral antibiotics or intravenous infusions of antibiotics to limit nosocomial exposure to SARS-CoV2. Patients with high-risk febrile neutropenia should be hospitalized per standard of care [36]. Empiric antibiotics should be continued per standard of care in patients who test positive for SARS-CoV-2. Clinicians should also continuously evaluate neutropenic patients for emergent infections.

\section{Treating COVID-19 and Managing Chemotherapy in Patients With Cancer and COVID-19}

Retrospective studies suggest that patients with cancer who were admitted to the hospital with SARS-CoV-2 infection have a high case-fatality rate, with higher rates observed in patients with hematologic malignancies than in those with solid tumors [37,38].

Recommendations for the treatment of COVID-19 are the same for cancer patients as for the general population (AIII). See Antiviral Drugs That Are Approved or Under Evaluation for the Treatment of COVID-19 and Immunomodulators Under Evaluation for the Treatment of COVID-19 for more information. Dexamethasone treatment has been associated with a lower mortality rate in patients with COVID-19 who require supplemental oxygen or invasive mechanical ventilation [39]. In cancer patients, dexamethasone is commonly used to prevent chemotherapy-induced nausea, as a part of tumordirected therapy, and to treat inflammation associated with brain metastasis. The side effects of dexamethasone are expected to be the same in patients with cancer as in those without cancer. If possible, treatments that are not currently recommended for SARS-CoV-2 infection should be administered as part of a clinical trial, since the safety and efficacy of these agents have not been well-defined in patients with cancer.

The NCCN recommends discontinuing G-CSF and granulocyte-macrophage colony-stimulating factor in patients with cancer and acute SARS-CoV-2 infection who do not have bacterial or fungal infections to avoid the hypothetical risk of increasing inflammatory cytokine levels and pulmonary inflammation $[27,40]$. Secondary infections (e.g., invasive pulmonary aspergillosis) have been reported in critically ill patients with COVID-19 [41,42].

Decisions about administering cancer-directed therapy to patients with acute COVID-19 and those who are recovering from COVID-19 should be made on a case-by-case basis; clinicians should consider the indication for chemotherapy, the goals of care, and the patient's history of tolerance to the treatment (BIII). The optimal duration of time between resolution of infection and initiating or restarting cancer- 
directed therapy is unclear. Withholding treatment until COVID-19 symptoms have resolved is recommended, if possible. Prolonged viral shedding (detection of SARS-CoV-2 by molecular testing) may occur in cancer patients [2], although it is unknown how this relates to infectious virus and how it impacts outcomes. Therefore, there is no role for repeat testing in those recovering from COVID-19, and the decision to restart cancer treatments in this setting should be made on a case-by-case basis. The Panel recommends that clinicians who are treating COVID-19 in patients with cancer consult a hematologist or oncologist before adjusting cancer-directed medications (AIII).

\section{Medication Interactions}

The use of antiviral or immune-based therapies to treat COVID-19 can present additional challenges in cancer patients. Clinicians should pay careful attention to potential drug-drug interactions and overlapping toxicities between drugs that are used to treat COVID-19 and cancer-directed therapies, prophylactic antimicrobials, corticosteroids, and other medications (AIII).

Several antineoplastic medications have known interactions with therapies that are being investigated for COVID-19 [32]. For example, tocilizumab can interact with vincristine and doxorubicin. Any COVID-19 therapy that may cause QT prolongation must be used with caution in patients who are being treated with venetoclax, gilteritinib, or tyrosine kinase inhibitor therapy (e.g., nilotinib). Dexamethasone is commonly used as an antiemetic for cancer patients and is recommended for the treatment of certain patients with COVID-19 (see Therapeutic Management of Hospitalized Adults With COVID-19). Dexamethasone is a weak to moderate cytochrome P450 (CYP) 3A4 inducer; therefore, interactions with any CYP3A4 substrates need to be considered. Lopinavir/ritonavir is a CYP3A4 inhibitor, and it can increase methotrexate, vincristine, or ruxolitinib concentrations. Lopinavir/ ritonavir is not recommended for the treatment of COVID-19; however, patients may receive it in a clinical trial. In general, concomitant use of lopinavir/ritonavir and CYP3A4 substrates should be avoided. If lopinavir/ritonavir is used in combination with a cytotoxic drug that is also a CYP3A4 substrate, clinicians should monitor for toxicities of the cytotoxic drug and adjust the dose if necessary.

\section{Special Considerations in Children}

Preliminary published reports suggest that pediatric patients with cancer may have milder manifestations of COVID-19 than adult patients with cancer, although larger studies are needed [43-45]. Guidance on managing children with cancer during the COVID-19 pandemic is available from an international group with input from the International Society of Paediatric Oncology, the Children's Oncology Group, St. Jude Global, and Childhood Cancer International [46]. Two publications include guidance for managing specific malignancies, guidance for supportive care, and a summary of web links from expert groups that are relevant to the care of pediatric oncology patients during the COVID-19 pandemic [46,47]. Special considerations for using antivirals in immunocompromised children, including those with malignancy, are available in a multicenter guidance statement [48].

\section{References}

1. Dai M, Liu D, Liu M, et al. Patients with cancer appear more vulnerable to SARS-CoV-2: a multicenter study during the COVID-19 outbreak. Cancer Discov. 2020;10(6):783-791. Available at: https://www.ncbi.nlm.nih.gov/pubmed/32345594.

2. Shah V, Ko Ko T, Zuckerman M, et al. Poor outcome and prolonged persistence of SARS-CoV-2 RNA in COVID-19 patients with haematological malignancies; King's College Hospital experience. Br J Haematol. 2020;190(5):e279-282. Available at: https://www.ncbi.nlm.nih.gov/pubmed/32526039.

3. Yang K, Sheng Y, Huang C, et al. Clinical characteristics, outcomes, and risk factors for mortality in patients with cancer and COVID-19 in Hubei, China: a multicentre, retrospective, cohort study. Lancet Oncol. 2020;21(7):904-913. Available at: https://www.ncbi.nlm.nih.gov/pubmed/32479787.

4. Robilotti EV, Babady NE, Mead PA, et al. Determinants of COVID-19 disease severity in patients with cancer. Nat Med. 2020;26(8):1218-1223. Available at: https://www.ncbi.nlm.nih.gov/pubmed/32581323.

5. Giannakoulis VG, Papoutsi E, Siempos II. Effect of cancer on clinical outcomes of patients with COVID-19: a meta-analysis of patient data. JCO Glob Oncol. 2020;6:799-808. Available at: https://www.ncbi.nlm.nih.gov/pubmed/32511066.

6. Kuderer NM, Choueiri TK, Shah DP, et al. Clinical impact of COVID-19 on patients with cancer (CCC19): a cohort study. Lancet. 2020;395(10241):1907-1918. Available at: https://www.ncbi.nlm.nih.gov/pubmed/32473681.

7. Centers for Disease Control and Prevention. COVID-19 ACIP vaccine recommendations. Available at: https://www.cdc.gov/vaccines/hcp/acip-recs/vacc-specific/covid-19.html. Accessed January 6, 2021.

8. Loh M, Baruchel A, Biondi A, et al. COVID-19 and pediatric ALL: frequently asked questions. 2021. Available at: https://www.hematology.org/covid-19/covid-19-and-pediatric-all. Accessed April 15, 2021.

9. Centers for Disease Control and Prevention. Information about COVID-19 vaccines for people with allergies. 2021. Available at: https://www.cdc.gov/coronavirus/2019-ncov/vaccines/recommendations/specific-groups/allergies.html. Accessed April 15, 2021. 
10. Centers for Disease Control and Prevention. Interim clinical considerations for use of COVID-19 vaccines currently authorized in the United States. Available at: https://www.cdc.gov/vaccines/covid-19/info-by-product/clinical-considerations.html\#Contraindications. Accessed April 15, 2021.

11. Auletta J, Chemaly R, Khawaja F, et al. General principles of COVID-19 vaccines for immunocompromised patients. 2021. Available at: https://www.hematology.org/covid-19/ash-astct-covid-19-and-vaccines. Accessed April 15, 2021.

12. Khawaja F, Chemaly R, Dadwal S, et al. ASH-ASTCT COVID-19 vaccination for HCT and CAR T cell recipients: frequently asked questions. 2021. Available at: https://www.hematology.org/covid-19/ash-astct-covid-19-vaccination-for-hct-andcar-t-cell-recipients. Accessed April 15, 2021.

13. National Comprehensive Cancer Network. COVID-19 vaccination guide V2.0. 2021. Available at: https://www.nccn.org/covid-19.

14. Lo W, Whimbey E, Elting L, Couch R, Cabanillas F, Bodey G. Antibody response to a two-dose influenza vaccine regimen in adult lymphoma patients on chemotherapy. Eur J Clin Microbiol Infect Dis. 1993;12(10):778-782. Available at: https://www.ncbi.nlm.nih.gov/pubmed/8307050.

15. Wumkes ML, van der Velden AM, Los M, et al. Serum antibody response to influenza virus vaccination during chemotherapy treatment in adult patients with solid tumours. Vaccine. 2013;31(52):6177-6184. Available at: https://www.ncbi.nlm.nih.gov/pubmed/24176495.

16. Yarza R, Bover M, Paredes D, et al. SARS-CoV-2 infection in cancer patients undergoing active treatment: analysis of clinical features and predictive factors for severe respiratory failure and death. Eur J Cancer. 2020;135:242-250. Available at: https://www.ncbi.nlm.nih.gov/pubmed/32586724.

17. American Society of Clinical Oncology. ASCO pecial report: a guide to cancer care delivery during the COVID-19 pandemic. 2020. Available at: https://www.asco.org/sites/new-www.asco.org/files/content-files/2020-ASCO-Guide-CancerCOVID19.pdf.

18. American Society of Anesthesiologists. The ASA and APSF joint statement on perioperative testing for the COVID-19 virus. 2020. Available at: https://www.asahq.org/about-asa/newsroom/news-releases/2020/06/asa-and-apsf-joint-statement-on-perioperative-testing-for-the-covid-19-virus. Accessed April 15, 2021.

19. Centers for Disease Control and Prevention. Framework for healthcare systems providing non-COVID-19 clinical care during the COVID-19 pandemic. 2020. Available at: https://www.cdc.gov/coronavirus/2019-ncov/hcp/framework-nonCOVID-care.html. Accessed April 15, 2021.

20. Wang X, Zhou Q, He Y, et al. Nosocomial outbreak of COVID-19 pneumonia in Wuhan, China. Eur Respir J. 2020;55(6). Available at: https://www.ncbi.nlm.nih.gov/pubmed/32366488.

21. Luong-Nguyen $M$, Hermand $H$, Abdalla S, et al. Nosocomial infection with SARS-CoV-2 within departments of digestive surgery. J Visc Surg. 2020;157(3S1):S13-S18. Available at: https://www.ncbi.nlm.nih.gov/pubmed/32381426.

22. Rivett L, Sridhar S, Sparkes D, et al. Screening of healthcare workers for SARS-CoV-2 highlights the role of asymptomatic carriage in COVID-19 transmission. Elife. 2020;9. Available at: https://www.ncbi.nlm.nih.gov/pubmed/32392129.

23. Centers for Disease Control and Prevention. How to protect yourself and others. 2021. Available at: https://www.cdc.gov/coronavirus/2019-ncov/prevent-getting-sick/prevention.html. Accessed April 15, 2021.

24. American Society for Radiation Oncology. COVID-19 clinical guidance. 2020. Available at: https://www.astro.org/DailyPractice/COVID-19-Recommendations-and-Information/Clinical-Guidance. Accessed April 15, 2021.

25. 25. Yahalom J, Dabaja BS, Ricardi U, et al. ILROG emergency guidelines for radiation therapy of hematological malignancies during the COVID-19 pandemic. Blood. 2020;135(21):1829-1832. Available at: https://www.ncbi.nlm.nih.gov/pubmed/32275740.

26. Advani R, Bartlett N, LaCasce A, et al. COVID-19 and hodgkin lymphoma: frequently asked questions. 2020. Available at: https://www.hematology.org/covid-19/covid-19-and-hodgkin-lymphoma. Accessed April 15, 2021.

27. National Comprehensive Cancer Network. NCCN hematopoietic growth factors: short-term recommendations specific to issues with COVID-19 (SARS-CoV-2). 2020. Available at: https://jnccn.org/view/journals/jnccn/18/1/article-p12.xml. Accessed April 15, 2021.

28. Lee LYW, Cazier JB, Starkey T, et al. COVID-19 mortality in patients with cancer on chemotherapy or other anticancer treatments: a prospective cohort study. Lancet. 2020;395(10241):1919-1926. Available at: https://www.ncbi.nlm.nih.gov/pubmed/32473682.

29. Montopoli M, Zumerle S, Vettor R, et al. Androgen-deprivation therapies for prostate cancer and risk of infection by SARSCoV-2: a population-based study $(N=4532)$. Ann Oncol. 2020;31(8):1040-1045. Available at: https://www.ncbi.nlm.nih.gov/pubmed/32387456.

30. Koskinen M, Carpen O, Honkanen V, et al. Androgen deprivation and SARS-CoV-2 in men with prostate cancer. Ann Oncol. 2020;31(10):1417-1418. Available at: https://www.ncbi.nlm.nih.gov/pubmed/32615154.

31. Food and Drug Administration. Coronavirus (COVID-19) update: FDA provides updated guidance to address the urgent need for blood during the pandemic. 2020. Available at: https://www.fda.gov/news-events/press-announcements/coronavirus-covid-19-update-fda-provides-updated-guidance-address-urgent-need-blood-during-pandemic. Accessed April 15, 2020.

32. American Society of Hematology. COVID-19 resources. Available at: https://www.hematology.org/covid-19. Accessed April 15, 2020.

33. American Society of Clinical Oncology. Cancer treatment and supportive care. 2021. Available at: https://www.asco.org/asco-coronavirus-resources/care-individuals-cancer-during-covid-19/cancer-treatment-supportive-care. Accessed April 15, 2021.

34. Food and Drug Administration. COVID-19 frequently asked questions. 2020. Available at: https://www.fda.gov/emergency-preparedness-and-response/coronavirus-disease-2019-covid-19/covid-19-frequently-asked-questions. Accessed April 15, 2021.

35. Centers for Disease Control and Prevention. Clinical questions about COVID-19: questions and answers. 2021. Available at: https://www.cdc.gov/coronavirus/2019-ncov/hcp/faq.html\#Transmission. Accessed April 15, 2021.

36. National Comprehensive Cancer Network. Infectious disease management and considerations in cancer patients with documented or suspected COVID-19. 2020. Available at: https://www.nccn.org/docs/default-source/covid-19/2021covid-infectious-disease-management.pdf?sfvrsn=63f70c30 7. Accessed August 3, 2020.

37. Mehta V, Goel S, Kabarriti R, et al. Case fatality rate of cancer patients with COVID-19 in a New York hospital system. Cancer Discov. 2020;10(7):935-941. Available at: https://www.ncbi.nlm.nih.gov/pubmed/32357994.

38. Meng Y, Lu W, Guo E, et al. Cancer history is an independent risk factor for mortality in hospitalized COVID-19 patients: a propensity score-matched analysis. J Hematol Oncol. 2020;13(1):75. Available at: https://www.ncbi.nlm.nih.gov/pubmed/32522278.

39. RECOVERY Collaborative Group, Horby P, Lim WS, et al. Dexamethasone in hospitalized patients with COVID-19. N Engl J Med. 2021;384(8):693-704. Available at: https://www.ncbi.nlm.nih.gov/pubmed/32678530.

40. Nawar T, Morjaria S, Kaltsas A, et al. Granulocyte-colony stimulating factor in COVID-19: is it stimulating more than just the bone marrow? Am J Hematol. 2020;95(8):E210-E213. Available at: https://www.ncbi.nlm.nih.gov/pubmed/32419212. 
41. van Arkel ALE, Rijpstra TA, Belderbos HNA, van Wijngaarden P, Verweij PE, Bentvelsen RG. COVID-19-associated pulmonary aspergillosis. Am J Respir Crit Care Med. 2020;202(1):132-135. Available at: https://www.ncbi.nlm.nih.gov/pubmed/32396381.

42. Alanio A, Delliere S, Fodil S, Bretagne S, Megarbane B. Prevalence of putative invasive pulmonary aspergillosis in critically ill patients with COVID-19. Lancet Respir Med. 2020;8(6):e48-e49. Available at: https://www.ncbi.nlm.nih.gov/pub$\mathrm{med} / 32445626$.

43. Hrusak $\mathrm{O}$, Kalina $\mathrm{T}$, Wolf $\mathrm{J}$, et al. Flash survey on severe acute respiratory syndrome coronavirus-2 infections in paediatric patients on anticancer treatment. Eur J Cancer. 2020;132:11-16. Available at: https://www.ncbi.nlm.nih.gov/pubmed/32305831

44. Andre N, Rouger-Gaudichon J, Brethon B, et al. COVID-19 in pediatric oncology from French pediatric oncology and hematology centers: high risk of severe forms? Pediatr Blood Cancer. 2020;67(7):e28392. Available at: https://www.ncbi.nlm.nih.gov/pubmed/32383827.

45. de Rojas T, Perez-Martinez A. Cela E, et al. COVID-19 infection in children and adolescents with cancer in Madrid. Pediatr Blood Cancer. 2020;67(7):e28397. Available at: https://www.ncbi.nlm.nih.gov/pubmed/32383819.

46. Sullivan M, Bouffet E, Rodriguez-Galindo C, et al. The COVID-19 pandemic: a rapid global response for children with cancer from SIOP, COG, SIOP-E, SIOP-PODC, IPSO, PROS, CCI, and St. Jude Global. Pediatr Blood Cancer. 2020;67(7):e28409. Available at: https://www.ncbi.nlm.nih.gov/pubmed/32400924.

47. Bouffet E, Challinor J, Sullivan M, Biondi A, Rodriguez-Galindo C, Pritchard-Jones K. Early advice on managing children with cancer during the COVID-19 pandemic and a call for sharing experiences. Pediatr Blood Cancer. 2020;67(7):e28327. Available at: https://www.ncbi.nlm.nih.gov/pubmed/32239747.

48. Chiotos K, Hayes M, Kimberlin DW, et al. Multicenter initial guidance on use of antivirals for children with coronavirus disease 2019/Severe Acute Respiratory Syndrome Coronavirus 2. J Pediatric Infect Dis Soc. 2020;9(6):701-715. Available at: https://www.ncbi.nlm.nih.gov/pubmed/32318706.

$<\ldots>$

\title{
Influenza and COVID-19
}

Last Updated: October 22, 2020

\begin{abstract}
Influenza Vaccination
- Although data are lacking on influenza vaccination for persons with COVID-19, on the basis of practice for other acute respiratory infections, the Panel recommends that persons with COVID-19 should receive an inactivated influenza vaccine (BIII). The Centers for Disease Control and Prevention (CDC) has provided guidance on the timing of influenza vaccination for inpatients and outpatients with COVID-19 (see Interim Guidance for Routine and Influenza Immunization Services During the COVID-19 Pandemic).

Diagnosis of Influenza and COVID-19 When Influenza Viruses and SARS-CoV-2 Are Cocirculating

- Only testing can distinguish between severe acute respiratory syndrome coronavirus 2 (SARS-CoV-2) and influenza virus infections and identify SARS-CoV-2 and influenza virus coinfection.

- When SARS-CoV-2 and influenza viruses are cocirculating, the Panel recommends testing for both viruses in all hospitalized patients with acute respiratory illness (AllI).

- When SARS-CoV-2 and influenza viruses are cocirculating, the Panel recommends influenza testing in outpatients with acute respiratory illness if the results will change clinical management of the patient (BIII)

- Testing for other pathogens should be considered depending on clinical circumstances, especially in patients with influenza in whom bacterial superinfection is a well-recognized complication.

- See the CDC Information for Clinicians on Influenza Virus Testing and the Infectious Diseases Society of America (IDSA) Clinical Practice

Guidelines for more information.

Antiviral Treatment of Influenza When Influenza Viruses and SARS-CoV-2 Are Cocirculating

- The treatment of influenza is the same in all patients regardless of SARS-CoV-2 coinfection (AIII)

- The Panel recommends that hospitalized patients be started on empiric treatment for influenza with oseltamivir as soon as possible without waiting for influenza testing results (Allb). Antiviral treatment of influenza can be stopped when influenza has been ruled out by nucleic acid detection assay in upper respiratory tract specimens for nonintubated patients and in both upper and lower respiratory tract specimens for intubated patients.

- For influenza treatment in hospitalized and non-hospitalized patients, see the CDC and IDSA recommendations on antiviral treatment of influenza.

Rating of Recommendations: $A=$ Strong; $B=$ Moderate; $C=$ Optional

Rating of Evidence: I = One or more randomized trials without major limitations; lla = Other randomized trials or subgroup analyses of randomized trials; $l l b$ = Nonrandomized trials or observational cohort studies; $I I I=$ Expert opinion
\end{abstract}

\section{Introduction}

Influenza activity in the United States during the 2020-2021 influenza season is difficult to predict and could vary geographically and by the extent of severe acute respiratory syndrome coronavirus 2 (SARS-CoV-2) community mitigation measures. During early 2020, sharp declines in influenza activity coincided with implementation of SARS-CoV-2 control measures in the United States and several Asian countries [1-4]. Very low influenza virus circulation was observed in Australia, Chile, and South Africa during the typical Southern Hemisphere influenza season in 2020 [5]. Clinicians should monitor local influenza and SARS-CoV-2 activity (e.g., by tracking local and state public health surveillance data and testing performed at health care facilities) to inform evaluation and management of patients with acute respiratory illness.

\section{Influenza Vaccination}

There are no data on the safety, immunogenicity, or effectiveness of influenza vaccines in patients with mild COVID-19 or those who are recovering from COVID-19. Therefore, the optimal timing 
for influenza vaccination in these patients is unknown. The safety and efficacy of vaccinating persons who have mild illnesses from other etiologies have been documented [6]. On the basis of practice following other acute respiratory infections, the Panel recommends that persons with COVID-19 should receive an inactivated influenza vaccine (BIII). The Centers for Disease Control and Prevention (CDC) has provided guidance on the timing of influenza vaccination for inpatients and outpatients with COVID-19 (see Interim Guidance for Routine and Influenza Immunization Services During the COVID-19 Pandemic). It is not known whether dexamethasone or other immunomodulatory therapies for COVID-19 will affect the immune response to influenza vaccine. However, despite this uncertainty, as long as influenza viruses are circulating, an unvaccinated person with COVID-19 should receive the influenza vaccine once they have substantially improved or recovered from COVID-19. See influenza vaccine recommendations from CDC and the Advisory Committee on Immunization Practices.

\section{Clinical Presentation of Influenza Versus COVID-19}

The signs and symptoms of uncomplicated, clinically mild influenza overlap with those of mild COVID-19. Ageusia and anosmia can occur with both diseases, but these symptoms are more common with COVID-19 than with influenza. Fever is not always present in patients with either disease, particularly in patients who are immunosuppressed or elderly. Complications of influenza and COVID19 can be similar, but the onset of influenza complications and severe disease typically occurs within a week of illness onset whereas the onset of severe COVID-19 usually occurs in the second week of illness. Because of the overlap in signs and symptoms, when SARS-CoV-2 and influenza viruses are cocirculating, diagnostic testing for both viruses in people with an acute respiratory illness is needed to distinguish between SARS-CoV-2 and influenza virus, and to identify SARS-CoV-2 and influenza virus coinfection. Coinfection with influenza A or B viruses and SARS-CoV-2 has been described in case reports and case series [7-11], but the frequency, severity, and risk factors for coinfection with these viruses versus for infection with either virus alone are unknown.

\section{Which Patients Should be Tested for SARS-CoV-2 and influenza?}

When influenza viruses and SARS-CoV-2 are cocirculating in the community, SARS-CoV-2 testing and influenza testing should be performed in all patients hospitalized with suspected COVID-19 or influenza (see Testing for SARS-CoV-2 Infection) (AIII). When influenza viruses and SARS-CoV-2 are cocirculating in the community, SARS-CoV-2 testing should be performed in outpatients with suspected COVID-19, and influenza testing can be considered in outpatients with suspected influenza if the results will change clinical management of the illness (BIII). Several multiplex assays that detect SARS-CoV-2 and influenza A and B viruses have received Food and Drug Administration Emergency Use Authorization and can provide results in 15 minutes to 8 hours on a single respiratory specimen [12,13]. For information on available influenza tests, including clinical algorithms for testing of patients when SARS-CoV-2 and influenza viruses are cocirculating, see the CDC Information for Clinicians on Influenza Virus Testing and recommendations of the Infectious Diseases Society of America (IDSA) on the use of influenza tests and interpretation of testing results [14].

\section{Which Patients Should Receive Antiviral Treatment of Influenza?}

When SARS-CoV-2 and influenza viruses are cocirculating in the community, patients who require hospitalization and are suspected of having either or both viral infections should receive influenza antiviral treatment with oseltamivir as soon as possible without waiting for influenza testing results (AIIb) [14]. Treatment for influenza is the same for all patients regardless of SARS-CoV-2 coinfection (AIII). See the CDC Influenza Antiviral Medications: Summary for Clinicians, including clinical algorithms for antiviral treatment of patients with suspected or confirmed influenza when SARS-CoV-2 and influenza viruses are cocirculating, and the IDSA Clinical Practice Guidelines recommendations on antiviral treatment of influenza.

If a diagnosis of COVID-19 or another etiology is confirmed and if the result of an influenza nucleic acid detection assay from an upper respiratory tract specimen is negative:

- In a Patient Who is Not Intubated: Antiviral treatment for influenza can be stopped.

- In a Patient Who is Intubated: Antiviral treatment for influenza should be continued and if a lower respiratory tract specimen (e.g., endotracheal aspirate) can be safely obtained, it should be tested by 
influenza nucleic acid detection. If the lower respiratory tract specimen is also negative, influenza antiviral treatment can be stopped.

\section{Treatment Considerations for Hospitalized Patients With Suspected or Confirmed SARS-CoV-2 and Influenza Virus Coinfection}

- Corticosteroids, which may be used for the treatment of COVID-19, may prolong influenza viral replication and viral RNA detection and may be associated with poor outcomes [14,15].

- Oseltamivir has no activity against SARS-CoV-2 [16]. Oseltamivir does not have any known interactions with remdesivir.

- Standard-dose oseltamivir is well absorbed even in critically ill patients. For patients who cannot tolerate oral or enterically administered oseltamivir (e.g., because of gastric stasis, malabsorption, or gastrointestinal bleeding), intravenous peramivir is an option [14]. There are no data on peramivir activity against SARS-CoV-2.

- CDC does not recommend inhaled zanamivir and oral baloxavir for the treatment of influenza in hospitalized patients because of insufficient safety and efficacy data (see the CDC Influenza Antiviral Medications: Summary for Clinicians). There are no data on zanamivir activity against SARS-CoV-2. Baloxavir has no activity against SARS-CoV-2 [16].

- Based upon limited data, the co-occurrence of community-acquired secondary bacterial pneumonia with COVID-19 appears to be infrequent and may be more common with influenza [17,18]. Typical bacterial causes of community-acquired pneumonia with severe influenza are Staphylococcus aureus (methicillin-resistant $S$. aureus [MRSA] and methicillin-susceptible $S$. aureus [MSSA]), Streptococcus pneumoniae, and group A Streptococcus [14].

- Patients with COVID-19 who develop new respiratory symptoms with or without fever or respiratory distress, and without a clear diagnosis, should be evaluated for the possibility of nosocomial influenza.

\section{References}

1. Kuo SC, Shih SM, Chien LH, Hsiung CA. Collateral benefit of COVID-19 control measures on influenza activity, Taiwan. Emerg Infect Dis. 2020;26(8):1928-1930. Available at: https://www.ncbi.nlm.nih.gov/pubmed/32339091.

2. Soo RJJ, Chiew CJ, Ma S, Pung R, Lee V. Decreased influenza incidence under COVID-19 control measures, Singapore. Emerg Infect Dis. 2020;26(8):1933-1935. Available at: https://www.ncbi.nlm.nih.gov/pubmed/32339092.

3. Suntronwong N, Thongpan I, Chuchaona W, et al. Impact of COVID-19 public health interventions on influenza incidence in Thailand. Pathog Glob Health. 2020;114(5):225-227. Available at: https://www.ncbi.nlm.nih.gov/pubmed/32521210.

4. Lei H, Xu M, Wang X, et al. Non-pharmaceutical interventions used to control COVID-19 reduced seasonal influenza transmission in China. J Infect Dis. 2020; Published online ahead of print. Available at: https://www.ncbi.nlm.nih.gov/pubmed/32898256.

5. Olsen SJ, Azziz-Baumgartner E, Budd AP, et al. Decreased influenza activity during the COVID-19 pandemic-United States, Australia, Chile, and South Africa, 2020. MMWR Morb Mortal Wkly Rep. 2020;69(37):1305-1309. Available at: https://www.ncbi.nlm.nih.gov/pubmed/32941415.

6. Centers for Disease Control and Prevention. Contraindications and precautions. General best practice guidelines for immunization: best practices guidance of the advisory committee on immunization practices (ACIP). 2020. Available at: https://www.cdc.gov/vaccines/hcp/acip-recs/general-recs/contraindications.html. Accessed October 16, 2020.

7. Hashemi SA, Safamanesh S, Ghasemzadeh-Moghaddam H, Ghafouri M, Azimian A. High prevalence of SARS-CoV-2 and influenza A virus (H1N1) coinfection in dead patients in Northeastern Iran. J Med Virol. 2020; Published online ahead of print. Available at: https://www.ncbi.nlm.nih.gov/pubmed/32720703.

8. Huang BR, Lin YL, Wan CK, et al. Co-infection of influenza B virus and SARS-CoV-2: A case report from Taiwan. J Microbiol Immunol Infect. 2020; Published online ahead of print. Available at: https://www.ncbi.nlm.nih.gov/pubmed/32646801.

9. Yue $\mathrm{H}$, Zhang $\mathrm{M}$, Xing $\mathrm{L}$, et al. The epidemiology and clinical characteristics of co-infection of SARS-CoV-2 and influenza viruses in patients during COVID-19 outbreak. J Med Virol. 2020; Published online ahead of print. Available at: https://www.ncbi.nlm.nih.gov/pubmed/32530499.

10. Cuadrado-Payan E, Montagud-Marrahi E, Torres-Elorza M, et al. SARS-CoV-2 and influenza virus co-infection. Lancet. 2020. Available at: https://www.ncbi.nlm.nih.gov/pubmed/32423586.

11. Wu X, Cai $Y$, Huang $X$, et al. Co-infection with SARS-CoV-2 and influenza A virus in patient with pneumonia, China. Emerg Infect Dis. 2020;26(6):1324-1326. Available at: https://www.ncbi.nlm.nih.gov/pubmed/32160148.

12. Food and Drug Administration. Coronavirus disease 2019 (COVID-19) emergency use authorizations for medical devices. Individual EUAs for molecular diagnostic tests for SARS-CoV-2. 2020. Available at: https://www.fda.gov/medicaldevices/coronavirus-disease-2019-covid-19-emergency-use-authorizations-medical-devices/vitro-diagnosticseuas\#individual-molecular. Accessed October 16, 2020.

13. Centers for Disease Control and Prevention. Table 4. Multiplex assays authorized for simultaneous detection of influenza viruses and SARS-CoV-2 by FDA. 2020. Available at: https://www.cdc.gov/flu/professionals/diagnosis/table-flu-covid19detection.html. Accessed October 16, 2020. 
14. Uyeki TM, Bernstein HH, Bradley JS, et al. Clinical practice guidelines by the Infectious Diseases Society of America: 2018 update on diagnosis, treatment, chemoprophylaxis, and institutional outbreak management of seasonal influenza. Clin Infect Dis. 2019;68(6):e1-e47. Available at: https://www.ncbi.nlm.nih.gov/pubmed/30566567.

15. Zhou Y, Fu X, Liu X, et al. Use of corticosteroids in influenza-associated acute respiratory distress syndrome and severe pneumonia: a systemic review and meta-analysis. Sci Rep. 2020;10(1):3044. Available at: https://www.ncbi.nlm.nih.gov/pubmed/32080223.

16. Choy KT, Wong AY, Kaewpreedee P, et al. Remdesivir, lopinavir, emetine, and homoharringtonine inhibit SARS-CoV-2 replication in vitro. Antiviral Res. 2020. Available at: https://www.ncbi.nlm.nih.gov/pubmed/32251767.

17. Vaughn VM, Gandhi T, Petty LA, et al. Empiric antibacterial therapy and community-onset bacterial co-infection in patients hospitalized with COVID-19: a multi-hospital cohort study. Clin Infect Dis. 2020; published online ahead of print. Available at: https://www.ncbi.nlm.nih.gov/pubmed/32820807.

18. Adler H, Ball R, Fisher M, Mortimer K, Vardhan MS. Low rate of bacterial co-infection in patients with COVID-19. Lancet Microbe. 2020. Available at: https://www.ncbi.nlm.nih.gov/pubmed/32835331.

\section{Правила подачі та оформлення статей}

Авторська стаття направляється до редакції електронною поштою у форматі MS Word. Стаття супроводжується офіційним направленням від установи, в якій була виконана робота, з візою керівництва (наукового керівника), завіреним круглою печаткою установи, експертним висновком про можливість відкритої публікації, висновком етичного комітету установи або національної комісії з біоетики. На останній сторінці статті мають бути власноручні підписи всіх авторів та інформація про відсотковий внесок у роботу кожного 3 авторів.

Приймаються оригінали супровідних документів з примірником рукопису, підписаного автором(ами), надіслані поштою, або скановані копії вищезазначених документів і першої (титульної) сторінки статті з візою керівництва, печаткою установи і підписами всіх авторів у форматі Adobe Acrobat (*.pdf), надіслані на електронну адресу редакції.

Статті приймаються українською, російською або англійською мовами.

Структура матеріалу: вступ (стан проблеми за даними літератури не більше ніж 5-7-річної давності); мета, завдання, матеріали та методи; результати дослідження та їх обговорення (висвітлення статистично опрацьованих результатів дослідження); висновки; перспективи подальших досліджень у даному напрямку; список літератури (два варіанти); реферати українською, російською та англійською мовами.

Реферат є незалежним від статті джерелом інформації, коротким і послідовним викладенням матеріалу публікації за основними розділами і має бути зрозумілим без самої публікації. Його обсяг не повинен бути менше $300-350$ слів. Обов'язково подаються ключові слова (від 3 до 8 слів) у порядку значущості, що сприятиме індексуванню статті в інформаційно-пошукових системах. Реферат до оригінальної статті повинен мати структуру, що повторюе структуру статті: мета дослідження; матеріали і методи; результати; висновки; ключові слова. Усі розділи у рефераті мають бути виділені в тексті жирним шрифтом. Для інших статей (огляд, лекція, клінічний випадок тощо) реферат повинен включати короткий виклад основної концепції статті та ключові слова.

Оформлення статті. На першій сторінці зазначаються: індекс УДК ліворуч, ініціали та прізвища авторів, назва статті, назва установ, де працюють автори та виконувалось дослідження, місто, країна. За умови проведення досліджень із залученням будь-яких матеріалів людського походження, в розділі «Матеріали і методи» автори повинні зазначати, що дослідження проводилися відповідно до стандартів біоетики, були схвалені етичним комітетом установи або національною комісією з біоетики. Те саме стосується і досліджень за участю лабораторних тварин.

Наприклад: «Дослідження виконані відповідно до приниипів Гельсінської Декларащії. Протокол дослідження ухвалений Локальним етичним комітетом (ЛЕК) всіх зазначених у роботі установ. На проведення досліджень було отримано поінформовану згоду батьків дітей (або їхніх опікунів)».

«Під час проведення експериментів із лабораторними тваринами всі біоетичні норми та рекомендаиії були дотримані».

Кількість ілюстрацій (рисунки, схеми, діаграми, фото) має бути мінімальною. Діаграми, графіки, схеми будуються у програмах Word або Excel; фотографії повинні мати один із наступних форматів: PDF, TIFF, PSD, EPS, AI, CDR, QXD, INDD, JPG (150-600 dpi).

Таблищі та рисунки розташовують у тексті статті відразу після першого згадування. У підпису до рисунку наводять його назву, розшифровують усі умовні позначки (цифри, літери, криві тощо). Таблиці мають бути оформлені відповідно до вимог ДАК, бути компактними, пронумерованими, мати назву. Номери таблиць, їхні заголовки і цифрові дані, оброблені статистично, повинні точно відповідати наведеним у тексті статті.

Посилання на літературні джерела у тексті позначаються цифрами у квадратних дужках та відповідають нумерації у списку літератури. Статті зі списком літературних джерел у вигляді посилань на кожній сторінці або кінцевих посилань не приймаються.

Необхідно подавати два варіанти списку літератури.

Перший (основний) варіант наводиться одразу після тексту статті, джерела розташовуються за алфавітом. Список літератури наводиться латиницею. Джерела на українській та російській мовах наводяться у тому написанні, як вони зазначені та реєструються на англійських сторінках сайтів журналів. Якщо джерело не має назви англійською мовою - воно наводиться у транслітерації. Таке оформлення списку літератури необхідно для аналізу статті та посилань на авторів у міжнародних наукометричних базах даних, підвищення індексу цитування авторів.

Другий варіант повторює перший, але джерела на українській та російській мовах подаються в оригінальній формі. Цей варіант необхідний для оформлення електронних версій журналу на російській та українській сторінках, цитованості у кирилічних наукометричних базах.

Згідно з Наказом МОН України №40 від 12.01.2017р. «Про затвердження вимог до оформлення дисертацій» оформлення списку літератури здійснюється відповідно стилю APA (American Psychological Association style), що може використовуватися у дисертаційних роботах.

Приклади оформлення літературних джерел:

Author AA, Author BB, Author CC. (2005). Title of the article. Title of Journal. 10(2);3:49-53.

Author AA, Author BB, Author CC. (2006). Titile of the book. Sity: Publisher: 256.

У тексті статті допускаються загальноприйняті скорочення, а також авторські скорочення, які обов'язково розшифровуються у тексті при першому згадуванні та залишається незмінними по всьому тексту. У кінці статті автори мають заявити про наявність будь-яких конкуруючих фінансових інтересів щодо написання статті. Зазначення конфлікту інтересів або його відсутності у статті є обов'язковим.

Приклад: «Автори заявляють про відсутність конфлікту інтересів» або «Матеріал підготовлений за підтримки компанії..»

Стаття закінчуеться відомостями про усіх авторів. Зазначаються прізвище, ім'я, по батькові (повністю), вчений ступінь, вчене звання, посада в установі/установах, робоча адреса з поштовим індексом, робочий телефон і адреса електронної пошти; ідентифікатор ORCID (https://orcid.org/register). Автор, відповідальний за зв'язок із редакцією, надає свій мобільний/контактний номер телефона.

Відповідальність за достовірність та оригінальність наданих матеріалів (фактів, цитат, прізвищ, імен, результатів досліджень тощо) несуть автори.

Редакція забезпечує рецензування статей, виконує спеціальне та літературне редагування, залишає за собою право скорочувати обсяг статей. Відмова авторам у публікації статті може здійснюватися без пояснення причин и не вважається негативним висновком щодо наукової та практичної значущості роботи.

Статті, оформлені без дотримання правил, не розглядаються і не повертаються авторам. 


\section{WORLD THROMBOSIS DAY 13OCTOBER}

\section{\#Ukraine_support WTD 2022}
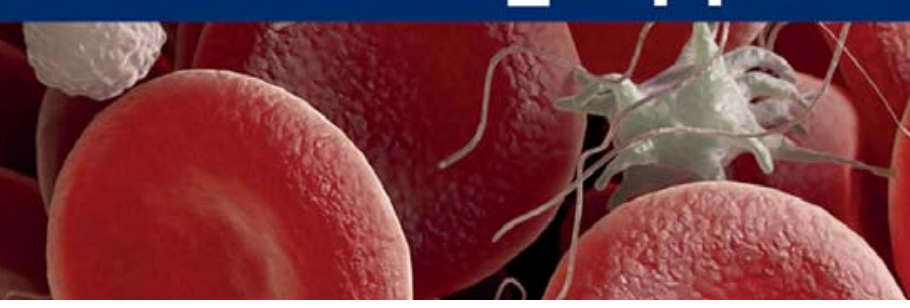

\section{Шановний колего!}

Ми прагнемо підвищити обізнаність про тромбоз, включаючи його причини, фактори ризику, симптоми та доказову профілактику і лікування. Зрештою, ми прагнемо зменшити смертність та інвалідність, спричинену цим станом.

Наша місія підтримує глобальну ціль Всесвітньої Асамблеї охорони здоров'я щодо скорочення передчасної смертності від неінфекційних захворювань на 25 відсотків до 2025 року.

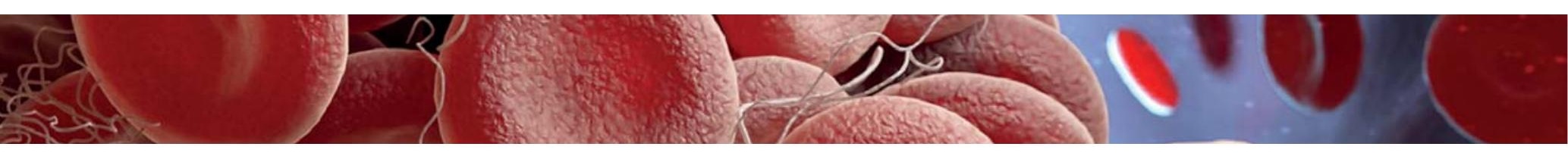

Долучайтесь! Збережемо здоров'я нації! Обізнаний сьогодні - врятований завтра! Разом ми сила!

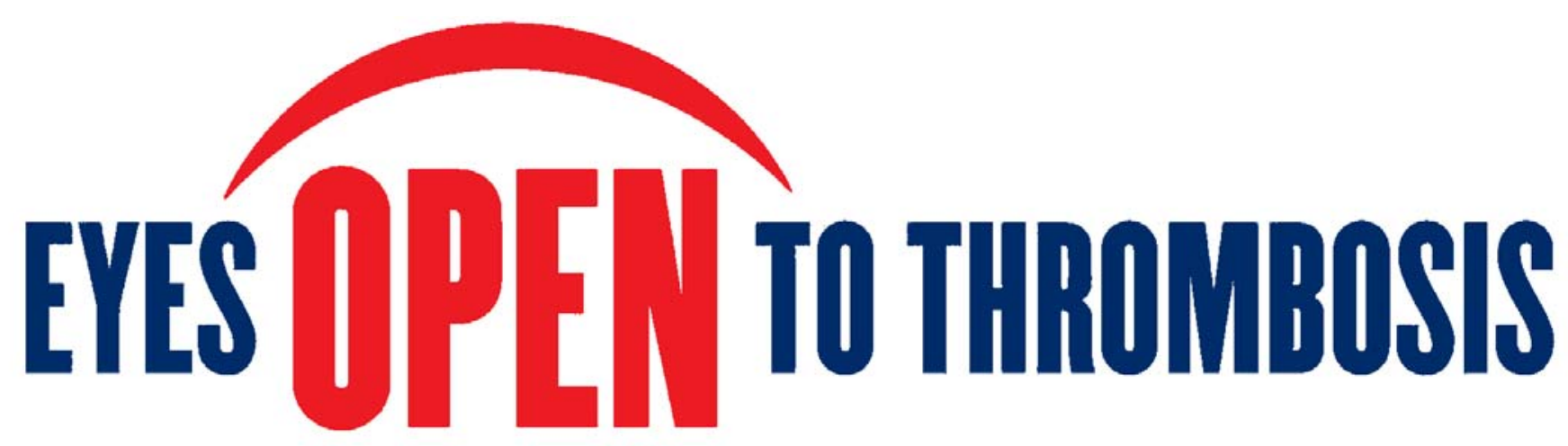

wtd-ukraine.org 


\section{Antibiotic resistance STOP!}

Стійкість до антибіотиків зростає до загрозливо високих рівнів у всьому світі. Нові механізми.стійкості з'являються і поширюються всюди, створюючи перешкоди для лікування розповсюджених інфекційних захворювань

- World Health Organization

\section{ANTIBIOTIC RESISTANCE}

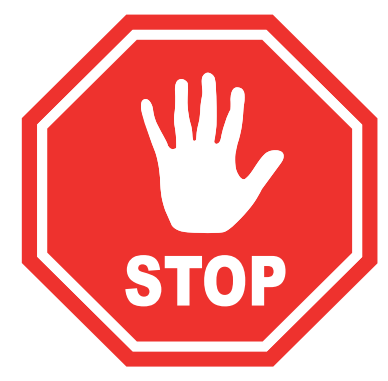

Розвиток нових антибіотиків має надзвичайне значення, оскільки еволюція мікробів продовжуватиметься безперервно, а резистентність долікарських засобів зростає.

Проблема антибіотикорезистентності стала глобальним викликом сьогодення. Головною його причиною вважають нераціональне застосування антибактеріальної терапії.

Тож під час Всесвітнього тижня поінформованості про антибіотики, в Українї традиційно буде проведено

IV міжнародний конгрес «Antibiotic resistance STOP!»,

який об'єднає провідних спеціалістів медичної галузі для розробки стратегії контролю розвитку антибіотикорезистентності 